\title{
The Transformation of Urban Space in Post-Soviet Russia
}

Konstantin Axenov, Isolde Brade and Evgenij Bondarchuk

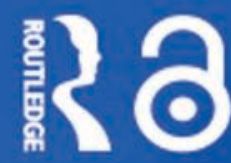




\section{The Transformation of Urban Space in Post-Soviet Russia}

In the years since 1989, the societies of Russia and Eastern Europe have undergone a remarkable transformation from socialism to democracy and free market capitalism. This book considers the change in the spatial structure of post-Soviet urban spaces since the period of transition began. It argues that the era of transformation can be considered as largely complete, and that this has given way to a new stage of development as part of the global urban and economic system: post-transformation. It examines the contemporary trends in the urban development of Western and post-socialist countries, and explores the theories of the transformation and post-transformation of urban space. It goes on to investigate the dynamics and results of spatial transformation, and includes detailed analysis of the Russian city of St Petersburg and the changing structure of its retail trade and services sector. Overall, this book is an important step forward in the study of the spatial dynamics of urban transformation in the former communist world.

Konstantin Axenov is Associate Professor in the Department of Regional Diagnostics and Political Geography at St Petersburg State University. His main research interests are urban and political geography.

Isolde Brade is Senior Researcher in the Department of European Regional Geography at the Leibniz Institute of Regional Geography, Leipzig. Her research interests are focused on geographical city and city system research with a regional emphasis on Eastern Europe and Russia.

Evgenij Bondarchuk is Director of the Scientific Institute for Applied Geography \& Territorial Management, St Petersburg. His main fields of interest are urban geography and the spatial research of retail. 


\section{BASEES/Routledge Series on Russian and East European Studies}

Series editor: Richard Sakwa, Department of Politics and International Relations, University of Kent

\section{Editorial Committee:}

Julian Cooper, Centre for Russian and East European Studies, University of Birmingham

Terry Cox, Department of Central and East European Studies, University of Glasgow

Rosalind Marsh, Department of European Studies and Modern Languages, University of Bath

David Moon, Department of History, University of Durham

Hilary Pilkington, Department of Sociology, University of Warwick

Stephen White, Department of Politics, University of Glasgow

\section{Founding Editorial Committee Member:}

George Blazyca, Centre for Contemporary European Studies, University of Paisley

This series is published on behalf of BASEES (the British Association for Slavonic and East European Studies). The series comprises original, highquality, research-level work by both new and established scholars on all aspects of Russian, Soviet, post-Soviet and East European studies in humanities and social science subjects.

\section{Ukraine's Foreign and Security} Policy, 1991-2000

Roman Wolczuk

2 Political Parties in the Russian Regions

Derek S. Hutcheson

3 Local Communities and PostCommunist Transformation Edited by Simon Smith

4 Repression and Resistance in Communist Europe

J. C. Sharman

5 Political Elites and the New Russia Anton Steen

6 Dostoevsky and the Idea of Russianness Sarah Hudspith
7 Performing Russia - Folk Revival and Russian Identity

Laura J. Olson

8 Russian Transformations Edited by Leo McCann

9 Soviet Music and Society under Lenin and Stalin The Baton and Sickle Edited by Neil Edmunds

10 State Building in Ukraine The Ukrainian parliament, 1990-2003 Sarah Whitmore

11 Defending Human Rights in Russia Sergei Kovalyov, Dissident and Human Rights Commissioner, 1969-2003 Emma Gilligan 
12 Small-Town Russia

Postcommunist Livelihoods and Identities: A Portrait of the Intelligentsia in Achit, Bednodemyanovsk and Zubtsov, 1999-2000

Anne White

13 Russian Society and the Orthodox Church

Religion in Russia after

Communism

Zoe Knox

14 Russian Literary Culture in the Camera Age

The Word as Image

Stephen Hutchings

15 Between Stalin and Hitler

Class War and Race War on the Dvina, 1940-46

Geoffrey Swain

16 Literature in Post-Communist Russia and Eastern Europe The Russian, Czech and Slovak Fiction of the Changes 1988-98 Rajendra A. Chitnis

17 Soviet Dissent and Russia's Transition to Democracy Dissident Legacies Robert Horvath

18 Russian and Soviet Film Adaptations of Literature, 1900-2001

Screening the Word Edited by Stephen Hutchings and Anat Vernitski

19 Russia as a Great Power Dimensions of Security under Putin Edited by Jakob Hedenskog, Vilhelm Konnander, Bertil Nygren, Ingmar Oldberg and Christer Pursiainen
20 Katyn and the Soviet Massacre of 1940

Truth, Justice and Memory

George Sanford

21 Conscience, Dissent and Reform in Soviet Russia

Philip Boobbyer

22 The Limits of Russian Democratisation

Emergency Powers and States of Emergency Alexander N. Domrin

23 The Dilemmas of Destalinisation A Social and Cultural History of Reform in the Khrushchev Era Edited by Polly Jones

24 News Media and Power in Russia Olessia Koltsova

25 Post-Soviet Civil Society

Democratization in Russia and the Baltic States Anders Uhlin

26 The Collapse of Communist Power in Poland Jacqueline Hayden

27 Television, Democracy and Elections in Russia Sarah Oates

28 Russian Constitutionalism Historical and Contemporary Development Andrey N. Medushevsky

29 Late Stalinist Russia

Society Between Reconstruction and Reinvention Edited by Juliane Fürst

30 The Transformation of Urban Space in Post-Soviet Russia Konstantin Axenov, Isolde Brade and Evgenij Bondarchuk 



\section{The Transformation of Urban Space in Post-Soviet Russia}

Konstantin Axenov, Isolde Brade and Evgenij Bondarchuk 
First published 2006

by Routledge

Published 2017 by Routledge

2 Park Square, Milton Park, Abingdon, Oxon OX14 4RN

711 Third Avenue, New York, NY 10017, USA

Routledge is an imprint of the Taylor \& Francis Group, an informa business

Copyright (C 2006 Konstantin Axenov, Isolde Brade and Evgenij Bondarchuk

Typeset in Times New Roman by

Florence Production Ltd, Stoodleigh, Devon

The Open Access version of this book, available at www.tandfebooks.com,

has been made available under a Creative Commons Attribution-Non

Commercial-No Derivatives 4.0 license.

British Library Cataloguing in Publication Data

A catalogue record for this book is available from the

British Library

Library of Congress Cataloging in Publication Data

Axenov, Konstantin, 1964-

The transformation of urban space in post-Soviet Russia /

Konstantin Axenov, Isolde Brade and Evgenij Bondarchuk.

p. cm. - (BASEES/Routledge series on Russian and East

European Studies)

Includes bibliographical references and index.

1. City planning - Russia (Federation). 2. Cities and towns -

Russia (Federation) - Growth. 3. City planning - Russia

(Federation) - Saint Petersburg. 4. Cities and towns - Russia

(Federation) - Saint Petersburg - Growth. 5. Post-communism -

Russia (Federation). I. Brade, Isolde. II. Bondarchuk, Evgenij,

1973- III. Title. IV. Series.

HT169.R8A94 2006

307.1'2160947-dc22

2006003846

ISBN13: 978-0-415-39739-1 (hbk) 


\section{Contents}

List of figures $\quad$ ix

List of tables

Preface xiii

1 Post-industrial vs. post-socialist: post-industrial trends and points for investigation in the post-socialist metropolis

Contemporary trends in urban development in Western industrialized countries 1

Contemporary trends in urban development in the post-socialist countries of Eastern Europe 8

Prerequisites for the development of the goods and services sector in large post-socialist cities 12

Transformation city and post-transformation city:

approaches to theory and research 17

2 Changes in the functions of St Petersburg as a prerequisite for structural change in the city

Geographical background 29

The opening-up of Russia 30

Development into a European metropolis 31

The Iron Curtain closes the 'window on Europe' 33

St Petersburg as a post-socialist metropolis 36

St Petersburg - a window to Russia? 55

3 Transformation, tertiary sector and city space: time-space approach

Spatial saturation: the mechanism for the adaptation of post-socialist urban space to the challenges of transformation 56 
viii Contents

Towards post-transformation: factors influencing the location of the tertiary sector in the new urban space 63

4 Transformation and specific forms of spatial saturation

Terms and definitions 73

Administrative regulation and the stages of development of specific transformation trade forms 74

Pavilions and markets stage, 1998-2001 95

Development of larger permanent trade forms, 2001-02 100

5 The spatial transformation of vertical business structures

The changing structure of the retail trade and services sector 1989-2002 107

Spatial saturation and vertical business structures 111

Urban morphology and the distribution of retail trade and services 115

Transportation patterns and the distribution of retail trade and services 123

General model and dynamics of the distribution of retail trade and services 126

Structure of the retail and services business and urban geography 131

6 Territorial complex building

Four types of territorial complex building 138

Appendix: the description of territorial complexes 144

7 Post-transformation urban space: the results of spatial saturation and the spatial organization of new business forms

The results of spatial saturation 152

The new demand structure and related shopping models 154

Post-transformational business forms and their locational preferences 156

8 Post-transformation vs. modernization: conclusions

Notes

Bibliography

Index 


\section{Figures}

2.1 The position of St Petersburg within Europe 30

2.2 Population development of St Petersburg 32

2.3 Russia's new ports on the Baltic 41

3.1 Representative example of retail activities that are typical of different levels in the hierarchy of commercial nucleations

3.2a Types of factors affecting the spatial distribution of businesses in the retail and services sectors in Leningrad in 1988: socialist period

3.2b Types of factors affecting the spatial distribution of businesses in the retail and services sectors in St Petersburg in 1996: transformation period

3.2c Types of factors affecting the spatial distribution of businesses in the retail and services sectors in St Petersburg in 2001: post-transformation period

4.1 Typical kiosk agglomeration, 1995

4.2 Percentage of purchases made from selected trading forms, St Petersburg, 1997

4.3 Food store on the ground floor of an apartment block near Primorskaya metro station, 1998

4.4 Location of kiosks and individual traders in Vyborgski district, 1994

4.5a Stage of under-saturated agglomeration, Pr. Prosveschenia case, 1989

$4.5 \mathrm{~b}$ Stage of mechanical saturation, Pr. Prosveschenia case, 1994

4.5c Recasting of an agglomeration, Pr. Prosveschenia case, 1995

4.6 Market place development in Leningrad-St Petersburg 94

4.7 Tents at Apraksin Dvor open-air market: (a) at 7.50 a.m., before opening; (b) at 9.42 a.m., working hours;

(c) at 6.32 p.m., market closed

$4.8 \quad$ Illegal private traders, 1998 


\section{$\mathrm{x} \quad$ Figures}

4.9 Pr. Prosveschenia agglomeration after the kiosks were removed, July $1996 \quad 98$

4.10 Tents migration at Pr. Prosveschenia agglomeration, $1998 \quad 99$

4.11 The interior of a pavilion at Pr. Prosveschenia, $1998 \quad 100$

4.12 Development of large trade complexes around metro stations, 2001

$\begin{array}{lll}5.1 & \text { Functional zones of St Petersburg } & 116\end{array}$

5.2 Tourism companies distribution by functional zones of St Petersburg, 1996-2002

5.3 Food stores distribution by functional zones of St Petersburg, 1996-2002

5.4 Automobile servicing distribution by functional zones of St Petersburg, 1996-2002

5.5 Hotels distribution by functional zones of St Petersburg, 1996-2002

5.6 Number of facilities of ten model branches, 1996, by average length of building

5.7 Number of facilities of ten model branches, 2002, by average length of building

5.8 Changes in density of 55 branches' facilities, 1988-96, by 15 model zones

5.9 Changes in density of 19 selected branches' facilities, 1996-2002, by 15 model zones

6.1 Udelnaya metro station kiosk agglomeration (fragment):

(a) July 1994; (b) December 1995

6.2 Kantemirovskaya-Grazhdanski territorial complexes, 1999

6.3 Salova street territorial complexes, 1999

6.4 Surveyed model zones

7.1 Estimated competitiveness of retail trade companies

7.2 Total trading space of hypermarkets in St Petersburg, in thousand square metres

$\begin{array}{lll}7.3 & \text { Super-Siwa complex, 2002 } & 160\end{array}$

$\begin{array}{lll}7.4 & \text { Lenta hypermarket, 2002 } & 160\end{array}$

7.5 Transformation-type facilities: recycling industrial constructions from socialist times into trading space, Staraya Derevnya, 2002

7.6 Post-transformation-type facilities: Mebel-City furniture retailer and Megamart cash-and-carry hypermarket, Staraya Derevnya, 2002

7.7 Sampsonievski hypermarket - post-transformational type of industrial buildings recycling

$\begin{array}{lll}7.8 & \text { Location of hypermarkets, April } 2002 & 164\end{array}$

$\begin{array}{ll}7.9 \text { Aquatoria business centre } & 172\end{array}$

$\begin{array}{ll}7.10 \text { 'Nobel' business centre } & 173\end{array}$ 


\section{Tables}

1.1 Three stages in the development of the spatial structure of the retail trade and services sector in Leningrad-

St Petersburg, 1985-2002

2.1 Proportion of industrial production in selected industries 35

2.2 Factors influencing the development of St Petersburg 40

2.3 Russian regions with the highest foreign investment in 1997 and 2002

2.4 Form of ownership of industrial enterprises in St Petersburg (1994-2000)

2.5 Development of the structure of industrial production in terms of the total volume of industrial production and total industrial employment

2.6 Funding of capital investments

2.7 Distribution of citizens employed in different industries in St Petersburg

2.8 Selected indicators for small businesses according to form of ownership, 2000

3.1 Range of options available to a market actor seeking office space in St Petersburg in 1994-95

3.2 Branches of the retail trade and services sector in which the number of facilities increased by more than ten times, 1989-96

4.1 Comparison of ridership volumes with size of kiosk agglomerations

4.2 Data on type of kiosk agglomeration

4.3 Showcase (shop window) area of separate traders in pavilions, 1998

4.4 Data on merchandise sold in kiosks/pavilions, Vyborgski rayon, 1994-98

4.5 Stages of spatial saturation with specific transformation trade forms in Leningrad-St Petersburg, 1989-2002

5.1 Changes in the structure of the retail and services sector, 1988, 1996, 2002 
xii Tables

5.2 Major locational preferences for the retail and services branches in St Petersburg in 1996-2002

5.3 Distribution of 19 selected branches and their facilities by the type of locational preference, 1996-2002

5.4 Changing significance of the city's morphological zones for the retail and services business, 1988, 1996, 2002

5.5 Number of 19 selected retail and services branches that represent branches of specialization for each of the 15 model sectors/zones of St Petersburg, 1996-2002

5.6 Changes in the branches of specialization for each of the 15 model sectors/zones of St Petersburg, 1996-2002

7.1 Dynamics of the retail trade turnover in St Petersburg

7.2 Income differential between the wealthiest and poorest sections of the population in St Petersburg, 1989-99

7.3 Average rent for office space in St Petersburg, 2000

8.1 Spatial dynamics of the distribution of the retail trade and services in Leningrad-St Petersburg, 1985-2002 


\section{Preface}

Global developments as well as local and regional factors have had an increasing influence on all areas of Russian society since the end of the era of socialist central planning. Nowhere is this clearer than in the cities, the economic nerve centres and the bearers of regional development. The cities have been the quickest to adapt to the changed demands of society. Political and institutional changes, the disintegration of established social structures and the introduction of market mechanisms have been concomitant with fundamentally new processes of spatial differentiation in Russian cities.

In the city of St Petersburg with its population of over 4 million, which we put into the focus of our study, these processes are leaving their mark on the urban fabric and transforming social and functional space in single quarters or whole municipal districts. For instance, the large industrial sites that during the socialist period were supposed to demonstrate economic strength declined in importance under the changed economic circumstances and are becoming increasingly derelict. Other parts of the city, in which previously only a minimum of amenities and services was provided for the residents, are becoming high-grade locations for retail and service functions. Still other locations within the city are only attractive for particular lines of business. The relationship between the centre and periphery is undergoing comprehensive transformation. Within a short period of time, new locational patterns emerge, primarily for the commercial and newly established service sectors; agglomerations of businesses with similar specializations or of a particular mix of businesses are formed, and new sub-centres develop. The large production and residential complexes continue to exhibit a certain spatial persistence. The unbelievable dynamism of the changes, as well as the sequential instability of these processes, are particularly striking.

This raises the question of the rules governing locational decisionmaking, and the factors influencing this. Can a revitalization of historical spatial and functional patterns be observed? To what extent is it possible to determine historical continuity with pre-revolutionary and Soviet roots? How important are post-Soviet regulatory mechanisms in the development of new spatial structures? 
The main objective of this study is to show the existence of two distinct stages that post-socialist cities experienced (or will experience) in their restructuring. We call these stages transformation and post-transformation, each of them having a different impact on city development. We have not aimed at discussing all socio-economic indicators and consequences of these stages. Our focus is on the development of city space. For the whole study we apply a time-space approach - all the spatial processes we examine in dynamics, trying to follow the consequence for spatial patterns and the mechanisms of change.

Peter Marcuse and Ronald van Kempen have suggested a term 'layered city' in order to indicate the existence of several overlapping spatial structures within city space, each having different mechanisms of their development but at the same time representing the city in the whole (Marcuse and van Kempen, 2000). We share this approach and use it in our study. In order to depict the existence of transformation and post-transformation spatial forms we shall not examine all 'layers' of city space. We shall take only one of them, which we consider one of the most sensitive to the dynamics of change. We shall examine the 'tertiary sector layer' as an indicator of the processes being described. We discuss reasons for doing this in the first chapters.

No comparative analysis was the subject of our present study. We believe, though, that St Petersburg as a case study is rather indicative. Being one of the biggest European metropolises, one of the distinct centres of political and economic innovations at least in Russia and parts of Eastern Europe, a rapidly developing multifunctional post-socialist economic centre, St Petersburg inevitably presents major trends in the development of inner city space that are common for many other centres of this part of the world.

All of these exciting issues induced a number of Russian and foreign academics - initially independently of each other - to commence fieldwork in St Petersburg. Inevitably, their paths soon crossed, and from the mid-1990s onwards both short-term and longer-term cooperation between the researchers developed, resulting in the publication of several articles in Russian, English and German.

This volume is the product of a collective research effort. It is primarily the result of joint fieldwork, but the many discussions between the researchers involved in this project and with other experts at home and abroad were also important. Our field research was completed in 2002, and all basic data that we use here refer to the period 1989-2002. Some revision of the research results was made in 2004 and several important additions were made then.

The research 'headquarters' were located in St Petersburg, Russia, where Dr Konstantin Axenov, a lecturer in the faculty of geography and geoecology at the St Petersburg State University, coordinated proceedings. He frequently provided insightful suggestions for the direction of our 
research, and posed incisive research questions, to which we found answers and explanations in our work together.

The following researchers were closely involved in the project: Dr Isolde Brade, a researcher at the Leibnitz Institute of Regional Geography in Leipzig, who has been doing joint research with Dr Axenov since 1995; Dr Evgenij Bondarchuk, who studied changing spatial structures in St Petersburg in his undergraduate dissertation and later wrote his doctoral thesis on this topic at the University of St Petersburg.

The authors are grateful to the contribution of Professor Alexis Papadopoulos, DePaul University, US, who examined the reasons behind the kiosk phenomenon with Dr Axenov in the early phases of the project.

Finally, the authors would like to express their gratitude to the Leibnitz Institute of Regional Geography in Leipzig for providing the all-important financial support.

Konstantin Axenov Isolde Brade Evgenij Bondarchuk Leipzig/St Petersburg, October 2005 



\title{
1 Post-industrial vs. post-socialist \\ Post-industrial trends and points for investigation in the post-socialist metropolis
}

\begin{abstract}
Discussions about economic restructuring, the tertiarization of production and its effects upon space, and about the service and information society, have been a feature of academic literature in Western countries for many years. Since the collapse of socialism, the end of the planned economy and the advent of transformation, these discussions, which are embedded within the wider issue of general urban development, have become more topical and meaningful for the countries of Eastern Europe.
\end{abstract}

\section{Contemporary trends in urban development in Western industrialized countries}

Certain social processes are currently taking place worldwide that are being accompanied by spatial restructuring on several levels. This can be observed on the international and transnational levels and can also be seen in changes within cities. These spatially relevant processes have been widely discussed in specialist literature, albeit almost exclusively in Western publications.

Wallerstein's 'world-system approach' has contributed greatly to the interpretation of the time-space relations in all spheres of social life and allowed for conceptualization of global shifts (Wallerstein, 1974, 1979, 1980). Major societal restructuring, which started worldwide in the 1970 s, has produced new structural determinants, collectively termed globalization (Taylor and Hoyler, 2000). These structures brought up a system of new world cities (Friedmann, 1986) or global cities (Sassen, 1991). David Clark suggests that two major trends underline the global urban development - shifts in global settlement systems are shaping the pattern of urban population majority and creation of a world city network forms what he refers to as the global city (Clark, 1996). That is, the development of a settlement system is coming to a state when, almost everywhere, the majority of populations live in cities. Also, major cities in the world are becoming interrelated in the form of a network, called the global city. Studies of the global cities have produced an extensive literature on the features of the global cities and numerous classifications of them. 


\section{Post-industrial vs. post-socialist}

Certain dissatisfaction has been expressed at the extent to which the external relations of global cities are studied (Beaverstock, Smith and Taylor, 1999; Taylor and Hoyler, 2000; Taylor, 2001). Empirical studies of world city networks have invented the concept of 'hinterworld' as a particular form of hinterland for world cities (Taylor, 2001). More important for our topic is finding the specific regional characteristics of global cities within globalization, discovering the regional features of European cities being of prime interest to some authors (Castells, 1993; Taylor and Hoyler, 2000). Similar concern persuaded others to use the term 'globalizing cities' to describe involvement in urban space of centres from the global periphery (Marcuse and van Kempen, 2000).

The concept of the metropolis has gained particular significance in these debates. Elisabeth Lichtenberger has, among others, posited the following thesis: in a united Europe, a new spatial way of thinking is ushering in the age of the metropolis (Lichtenberger, 1994, 1995). This refers particularly to the competition that is emerging between major cities for functional specialization at the transnational or international level. Indeed, it is largely the major metropolises that are becoming the setting, where processes triggered by the following factors are played out:

- The increasing globalization or internationalization of the economy particularly in the world of finance.

- The transition from the industrial age characterized by mass production and mass consumption to an age of consumer-orientated, highly specialized production and a service sector that is increasingly orientated towards the provision of business services.

Saskia Sassen writes of the development of a new global and regional hierarchy of cities, characterized by the so-called global cities, but also by:

widespread, increasingly marginalized areas that are excluded from the new economic processes. A large number of formerly important industrial cities and ports have lost their function and are in a process of decline ... This is also a sign of economic globalization.

(Sassen, 1996, p. 20)

Elsewhere, Stefan Krätke points out that the present phase of social development is being accompanied by a global shift in industry and growth centres:

A pattern of spatial development is emerging, which is shaped by the division between declining or stagnating urban regions and those areas which are still prosperous, and which brings with it an increase in socio-economic polarization within cities as well as new micro-spatial segregation processes.

(Krätke, 1991, p. 4) 
The majority of recent works in urban research (by authors such as Peter Taylor, Stephan Krätke and Saskia Sassen, and also by Hartmut Häussermann, Walter Prigge and Klaus Ronneberger, Manuel Castells and Elisabeth Lichtenberger) are based upon the premise that current changes to urban spaces and urban hierarchies (e.g. the emergence of global and Euro-city networks) are caused by global restructuring processes taking place within capitalist societies.

While many studies on urban development during the 1970s followed a socio-ecological approach ${ }^{1}$ (e.g. Friedrichs, 1978; Massotti and Hadden, 1973), contemporary theoretical interest in the development of urban spaces is orientated more towards the 'regulation approach' (Krätke, 1995; Hitz, Schmid and Wolff, 1992). This approach within social science views the development of capitalist societies as a succession of particular historical phases of development, in which appropriate political and institutional regulatory mechanisms emerge. If applied to urban research, this poses the following question according to Krätke: to what extent does a specific phase in historical development affect specific spatial and urban structures?

If one considers the Western European city in the 'Fordist phase' of development - also known as the late phase of the industrial age - the following characteristics stand out:

- the conception of the city as a monocentrically expanding system with a clearly demarcated core and fringe;

- the progressive 'zoning' of the urban area and standardization of urban areas;

- the separation of functions - work, living and provision with goods and services - leading to the development of mono-functional subareas;

- standardized mass housing construction;

- the acceptance of the mass consumption model.

The worldwide acceptance of Fordist-Keynesian ${ }^{2}$ economic thinking after the Second World War was reflected on the ground by recognizable spatial structures. Industrial complexes, based upon closely knit systems of production, required the spatial concentration of workers and resources for production. Initially, cities expanded in a star-shaped pattern, primarily along radial axes of public transport routes. The strict separation of industrial and residential areas was typical. With increased prosperity and mass motorization suburban growth was freed of this predetermined radial pattern, and there followed an extensive expansion of towns and cities that reached far into the urban field. In the US, this process had commenced even before the Second World War, due to the high levels of motorization (Hesse and Schmitz, 1998). The process of suburbanization that involved the migration of people, trade and industry from the centre to the fringe 
(resulting in a staggering increase in commuting and traffic flows) was one of the most important spatially relevant processes of the 1950s and 1960s. In 1950, there was 14 square metres of residential space per inhabitant; by the end of the 1990s this had risen to approximately 39 square metres per inhabitant (Aring, 1999). Inner city areas became increasingly depopulated, with the middle classes and white collar workers moving to suburban areas. The resulting space in the city centre was filled by 'lifeless' office buildings and business zones.

The typical spatial expression of this developmental phase in capitalist society was an urban agglomeration with 'more or less recognizable borders', with a standardized suburban belt of 'single-family houses for the middle classes and high-rise ghettos for the workers', resulting in social division and large-scale segregation (Hitz, Schmid and Wolff, 1992). The city was largely developed according to the classic spatial model of the Fordist city with concentric rings and sectors (Lichtenberger, 1998).

The Fordist phase of urban development remained a feature of the economic landscape in Western industrialized countries until the mid-1970s, when a massive structural crisis heralded the end of the industrial age. International economic processes changed radically under the influence of new communication and information technologies and globalizing tendencies driven by the imperatives of capital, technology and information. Deregulation and de-industrialization became the order of the day, as did the transition to flexible and specialized production structures, and the tertiarization and quarternization of production. The centrepiece of this new historical formation - 'post-Fordism' - is, according to Leborgne and Lipietz (1994), a shift in emphasis away from mass production towards the flexible specialization of the production process, i.e. the production of goods and services that are orientated towards specific consumer wishes.

The introduction of new technologies, modern methods of communication and computer integrated manufacturing, as well as new forms of organization (subcontracting) and production (just-in-time production), brought an end to the rigid Fordist system of production. Whole production units could now be outsourced and relocated to more advanced or cheaper corners of the world. The availability of a wide variety of economic locations - such as the high-wage, high-tech region of North America, regions with highly qualified personnel (Western Europe) or the attractive investment zones of Latin America and southern Asia (e.g. Hitz, Schmid and Wolff, 1992) - has provided the framework for the creation of globally integrated production systems and for the increasing internationalization of economic processes. The effect of this on urban hierarchies has been the emergence of global cities and high-tech or regional metropolises in international or transnational space. The major metropolises attempt to attract high-value services and advanced technologies in order to gain technological and locational advantages in the acquisition of important international functions, particularly in the financial sector. These 
cities are increasingly becoming 'the command centres of the world economy' (Sassen, 1991, 1996) and 'a crossroads, where global flows of information converge. They are the seats of the headquarter economy, places, where business-orientated services and economic regulatory functions are concentrated' (Clark, 1996; Burdack and Herfert, 1998). In this way, they are increasingly separating themselves from their national settlement systems and striving for integration into the newly emerging network of global cities or Euro-cities. Locational factors, such as the availability of human capital and important services, mean that only the major metropolises have a real chance of becoming part of this network. Through carefully targeted marketing and image-building campaigns cities attempt to improve their international competitiveness.

At the same time, the transition to flexible production structures is bringing about the restructuring of intra-urban space. Extensive growth beyond the city boundaries has characterized the main trends in urban development in the last few decades in Western Europe. This 'classical' suburbanization has been eclipsed since the 1980s by a new phase of development in the urban periphery. This 'post-suburban' phase of development is not defined by quantitative growth alone but, rather, increasingly by a functional enhancement of the city margins (Burdack, 2001, p. 189). The emergence of new regional production complexes, known as 'new industrial complexes' (Sassen, 1995), provides innovative new locations that act as magnets for growth industries and the business services sector. These locations, which are normally situated on the fringes of the metropolis and manifested in a variety of new spatial features, are often functionally specialized, occurring as industrial estates, business parks, office parks, etc. Others exhibit a mixture of functions, such as retailing and leisure.

In current discourses of regionalization, the city and its surrounding area are no longer understood in terms of a contrast between centre and periphery; rather, they are considered to form a spatial unit. When the term 'urban area' is used, this refers to the scale of the urban region. In contrast to developments in the US, however, there is no evidence that edge cities are emerging in European states. The reasons for this include differing urban traditions, modes of regulation and forms of economic growth.

The continuing trend towards suburbanization in Western industrialized countries is propelled by residential suburbanization, albeit at reduced rates, and in particular by the leisure and service industries, as well as by small businesses, which are increasingly moving to the city periphery. Household and business-orientated services are also contributing to the 'tertiarization of the suburban area' (Burdack and Herfert, 1998). These decentralized areas now provide the greatest concentration of employment and the fastest rates of employment growth within the urban region 
(Brake et al., 1996). Crucial to this Western model of urban development, however, is a high degree of individual mobility (Petz and Schmals, 1992).

New economic centres have now begun to develop independently of the city core, helped by their agglomeration advantages, which attract business and industry. As a result, the traditional centre-periphery urban structure of Western cities is slowly breaking down. The post-Fordist city is 'disintegrating' into specialized locations of a fragmentary nature (Burdack and Herfert, 1998), i.e. it is made up of "various specialized locations such as new towns and satellite-cities, linked by freeways, highspeed trains and fiber-optic cable ... Places, which are not connected to these links are being relegated to the urban periphery' (Hitz, Schmid and Wolff, 1992, p. 77). The development of urban regions is no longer concentrated on one pole - the city centre - as 'the new metropolis is much more decentralized, consisting more and more of a mosaic of unevenly developed living areas' (Soja, 1993, p. 213).

The role of the traditional Western city centre is currently undergoing a period of significant re-evaluation. It is extolled as a 'place for sophisticated consumption', representative of a 'new lifestyle'. While residential functions and so much of the 'life' of the city centre were squeezed out as the Fordist city centre was restructured into business and office zones, current urban development strategies focus on the development of districts that meet the needs of the 'new urban elites'. These new elites generally work in modern, highly paid sectors, and are representative of the headquarters economy. They view the city centre as a suitable place for projecting their own self-image, and as indicative of their own sophistication. New patterns of consumption are also initiating changes in spatial structures, and the creation of the corresponding post-modern 'architectural backdrops'. The centre has been rediscovered as a sophisticated place to live. Rising rents, luxury redevelopments and gentrification are slowly driving out the lower socio-economic classes, providing room for the new metropolitan elites. At the same time, city centres have not just become attractive places to live; they are also attracting high-quality services. Financial advisers and management consultants, realtors, advertising agencies, designers, artists and other 'creative' branches are moving to the inner city. Luxury shopping malls and art galleries, elegant restaurants, cafes, bars and bistros, leisure centres and cultural forums are emerging to meet the needs of the new inhabitants. Security cameras, security guards and iron gates are merely the outward signs of their perceived need to protect their new 'possessions' and guarantee the security of their 'lifestyle'. Formerly public places are becoming semi-public or even private spheres.

The Leibniz Institute of Regional Geography in Leipzig, Germany, has carried out comparative research into current developments in peripheral areas of city regions. ${ }^{3}$ The findings indicate that the following five characteristics distinguish post-suburban space from suburban space (Burdack 2001): 
1 Increased functional variety: peripheral areas are now places where people not only live but also work, spend their leisure time, and are educated.

2 Qualitative enhancement of the economic base: as well as jobs in manufacturing and household services, qualitatively high-value jobs are also created. The suburbs have become sites of the knowledge economy.

3 Emergence of new centres and cores: there is now more office space in new centres in the periphery than in the old downtown areas (office parks, office concentrations, mixed-use developments, sub-cities and suburban corridors, edge cities).

4 Reorientation of patterns of interaction and traffic flows: traffic and commuter flows are no longer centred on the city core, but are intensifying within the periphery.

5 Heterogeneous composition of the population and the variety of new lifestyles: the suburbs are no longer exclusively characterized by households in a particular phase of the family life cycle, but also by the inhabitants' career aspirations and consumption patterns.

The results of the project can be generalized as follows:

- Quantitatively and qualitatively, the formation of new growth areas in the peripheries of European cities lags significantly behind US cities. New growth areas do not generally develop in the outer periphery but, rather, adjacent to the main body of the morphological city, in the inner periphery.

- The less dynamic growth in the periphery can be attributed, in part, to the development of growth locations on brownfield sites in the inner periphery (e.g. former industrial sites, disused trading estates and transport facilities), which has reduced potential demand in the outer periphery.

- In contrast to the American edge cities, the new growth areas in the peripheries of European cities do not represent competition for the traditional city centre. The emergence of new growth areas in the periphery has not brought about the decline of the core city. The functional losses of the core cities in the area of industrial production are balanced out by gains in the significance of functions related to consumption and prestige. The city is not disintegrating.

In summary, the following can be said of urban development under conditions of postmodernity (post-Fordism): 'The creation of polycentric metropolises, the development of sub-cities and belt-cities in the agglomeration regions, the gentrification of the urban core (i.e. the takeover of established residential areas in the inner city by high-income groups) and new forms of micro-spatial segregation are all signs of this new phase of 
urbanization' (Hitz, Schmid and Wolff, 1992, p. 77). Industrial production, trade, and increasingly consumer services are moving further out in the conurbation, while office functions locate in the core cities.

\section{Contemporary trends in urban development in the post-socialist countries of Eastern Europe}

After the collapse of socialism and the decline of the formerly centrally controlled regulatory mechanisms, the cities of Eastern Europe are now faced with a radical change in their development. The processes of transformation in Eastern European societies have opened up the region to global influences. Analysis of structural change in Eastern European cities indicates that all of these cities are now facing a dual process of integration (Fassmann and Lichtenberger, 1995):

- On the one hand, the centrally controlled system of economic planning is being replaced by market economy structures.

- On the other hand, the opening up of Eastern European countries (including Russia) means that they are now influenced by the same global processes that are giving rise to economic and structural change worldwide. In turn, these processes lead to changes within cities.

The transformation process is thus taking place within the arena of internal restructuring and internationalization, yet it is also a part of the globalization process itself, as autarkic systems have been proven to be unstable in the face of increasingly interconnected global structures (Rudolph 1996).

Once again a mutual network of relations is being established on several levels between Western and Eastern European city systems. The development of the European network of metropolises has been aided in the past few decades by European integration, with the major Western European cities competing for special functions on a transnational or international scale. Eastern European cities are now hoping for rapid institutional integration with Western Europe, and wish to seize the opportunity to compete for particular functions within the European framework. This could result in a shift of emphasis within the European city system. During the socialist era, Eastern European cities were integrated into a specific autarkic national economic area. Administrative and service institutions provided the link to the catchment area, which was, in turn, determined by the state. The functional importance of Eastern European cities is now influenced not just by regional and national factors but also by transnational and international factors. The post-socialist metropolises are now competing for foreign investment and for closer ties to Western market economies. Yet relatively few cities are equal to this task. Foreign investors and international concerns seek high-quality infrastructure, business-orientated services, a good 
institutional framework and well-qualified personnel, but the experiences of the 1990s seem to confirm the expectation that, at present, only the primate cities in Eastern Europe will be able to compete on this level (Enyedi, 1994; Grimm et al., 1994; Fassmann and Lichtenberger, 1995). This is due to the fact that, during the socialist period, the majority of economic institutions, as well as the communications infrastructure, the research and development sector and human capital, were concentrated in the primate cities. The primate cities (in most cases the capital city) also continue to have the best prerequisites for face-to-face contacts in the political and economic arena. Enyedi (1994) concluded that of the east-central and southeastern European capital cities (Belgrade, Bratislava, Bucharest, Budapest, Ljubljana, Prague, Sofia, Warsaw and Zagreb), only Budapest, Prague and Warsaw fulfil the necessary requirements to be able to compete successfully with other European cities. They are greatly aided by the fact that a stable political and judicial system has already been established in their respective countries. The function of these three cities in the network of European metropolises is likely to be as a gate-way to eastern and southeastern Europe. Budapest and Warsaw have recognized this, and have already met the institutional requirements, as well as fostering international social and cultural relations. Prague, however, has concentrated on its cultural function and has, by and large, neglected economic relations with the former COMECON countries (members of the Council for Mutual Economic Assistance): '[Prague] expects that integration with the West can be effected more rapidly, if relations with the East are restricted, however, this position raises doubts about its suitability to take on the functions of a sub-regional center' (Enyedi, 1994, p. 69).

In Eastern Europe, the cities most capable of taking on national and international functions are Moscow, St Petersburg and possibly Kiev (Ukraine), due to their geographical location and their endogenous potential. In the case of Moscow, the concentration of political, economic and financial power in the city enables it to increasingly separate itself from the regional and national economic system and integrate itself in the international network of metropolises. In the case of St Petersburg, geographical location, the immediate proximity to the European Union (EU), its importance as an internationally recognized cultural centre and its economic potential contribute to making the city a centre for transport, communication and information in the Baltic region (see Chapter 2). Describing world city formation in Europe, Beaverstock, Smith and Taylor (1999) and Taylor and Hoyler (2000) classify European urban centres into four categories according to their involvement in the global network of the advanced producer services (accountancy, advertising, banking/finance and law). These are alpha, beta and gamma world cities, and cities showing the evidence of world city formation. Out of the Eastern European cities, Moscow (like Zürich or Brussels in Western Europe) could be 
treated as a beta world city, St Petersburg and Kiev show the evidence of world city formation (like Rotterdam, Lyon, Dublin or Lisbon) (Beaverstock, Smith and Taylor, 1999; Taylor and Hoyler, 2000). Taylor and Hoyler consider St Petersburg to belong to the 'minor spine' of cities that constitute the corporate service complexes in Europe. At the same time they classify St Petersburg as one of 'the most "un-European" cities' in their list, like the other "four Eastern European cities with local specificities that prevent them being very similar to other European cities' (Taylor and Hoyler, 2000). ${ }^{4}$

The transformation processes, which have been occurring in Eastern Europe since the early 1990s, raise the following question: What have been the specific spatial manifestations of societal change in Eastern European cities? Development processes in post-Soviet urban space occur under a completely different set of conditions to those in Western European towns and cities.

Important factors that were critical in shaping the development of the socialist city and that continue to influence the development of postsocialist cities include the following (cf. Burdack and Rudolph, 2001, p. 262; Oswald and Voronkov, 2002, p. 140): ${ }^{5}$

- Land was nationalized; market mechanisms played no significant role in the differentiation of land use; state and local authorities had free disposal of land for building and real estate; there was no public participation in decision-making on land use, and these decisions were not subject to independent discussion.

- Centralized economic and spatial planning; huge areas were designated for industrial usages without the involvement of local authorities; enterprises were allocated over-sized plots, and land was hoarded.

- Investment in non-productive sectors was permanently low; the tertiary sector, especially the consumer-oriented areas, was generally underdeveloped in socialist societies.

- The standardization of mass housing construction and state regulation of the housing sector (finance, allocation, administration and maintenance) with the aim of preventing the segregation of the urban population.

- The development of huge high-rise housing projects in the outer districts of urban areas; extensive growth on the periphery.

- The emergence of a broad belt of spacious 'leisure time settlements' around the city to counterbalance the cramped living conditions within in the city.

- 'Socialist style' segregation processes, which differed in form and intensity between countries; typical prestige factors in Russian cities - and therefore triggers for intra-urban segregation processes - were employment in a particular economic sector, level of education and 
membership of a particular profession; social differentiation based on economic factors tended to be secondary.

Urban development under socialist conditions did not follow a universally valid socialist model. In countries of Eastern Europe, it was possible to discern departures from the 'Soviet development model'. Nevertheless, common features and processes can be observed, which determined the development of towns and cities in the socialist states of Eastern Europe. The overarching aim in socialist urban development was the creation of equal living conditions. For Szelenyi (1996), however, the characteristic feature of the 'socialist city' is not a particular form of appearance nor an objective of socialist planners, but rather the fact that they are the cities of industrialized societies that have abolished the private ownership of the means of production (Burdack und Rudolph, 2001).

The post-socialist collapse of entire industries, which has had catastrophic socio-economic consequences both for the mono-structural small and medium-sized cities as well as for the larger cities, has in fact been partly compensated for by the rapid take-off of service-orientated private industry in the major metropolises (Lichtenberger, 1998). Even if this type of activity is classed as belonging to the 'informal sector' (Neef and Stanculescu, 2002), the fact remains that it is bringing a specific dynamism to the cities of Eastern Europe, because these new businesses emerging in the service sector generally require large sites or large expanses of office space (depending on the particular type of business). During the period of the state controlled planned economy, economic viability was not an obligation for most enterprises and industries, with the result that space in the city was often used in an economically inefficient manner. The vast majority of real estate was owned by the state, which allocated land to enterprises when it felt the need. Only after receiving this allocation did enterprises plan what use to make of this land. A typical characteristic of town planning was the designation of so-called 'reserve plots', with enterprises also fighting to get the largest amount of space possible. Thus, in contrast to Western cities, most Eastern European cities are characterized by a low building density.

This is changing with the sharp increase in demand for space from new businesses. In this respect, Eastern European cities again differ from their Western counterparts. Office and business complexes are not being built on the periphery, but within the city itself, as close to the centre as possible (Axenov, Brade and Bondarchuk, 1997). The sudden and massive demand of the tertiary sector for office space was initially met by the conversion of residential space into office space, as well as by the redevelopment and reconstruction of existing buildings. The construction of new complexes could only begin with the influx of foreign capital and the increased availability of local capital. 
The question of locational competition was also irrelevant during the socialist era:

[A] sectoral concentration in one location was both needless and uneconomical, because the relatively small selection of goods available in the socialist economy had to be distributed as simply as possible. The fact that all financial transactions took place via the state bank (with the exception of a few special banks) also meant that there was no need for a financial district with competing financial institutions.

(Rudolph, 1996, p. 75)

The introduction of a constitutionally guaranteed right to private property, the opening up of the economy and the liberalization of the real estate market has brought a completely new dimension to the importance of location. Land use has now become a decisive factor for speeding up structural reform in post-socialist cities. The reintroduction of land and property prices has led to particular functions becoming established at particular locations - i.e. companies with high levels of capital or, in the residential sector, prosperous sections of the population are to be found at the most attractive city locations, while companies with less capital and the 'lower classes' are being pushed into marginal districts (Roberts, 2003).

A further result of the processes of societal transformation has been the decentralization of power structures, with more decision-making at local and regional levels. In Russian cities, for example, individual actors now have the opportunity to take part in decision-making for the first time. Since the law on the self-government of the local authorities has come into force, it is the responsibility of the local authority to create the necessary framework for urban development (urban development concepts, plans for land use, plans for construction, etc.) and to preside over its progress (Brade, Piterski and Schulze, 2002).

The question is to what extent the locational profile of Eastern European cities will be determined by 'free forces', or to what extent the development of the urban structure will be influenced by regulative mechanisms.

\section{Prerequisites for the development of the goods and services sector in large post-socialist cities}

While trends in Western Europe since the 1970s show that industrialization has been superseded by tertiarization in all large cities, the Soviet Union continued a policy of massive industrialization even, or rather particularly, in cities with one or more million inhabitants until the end of the 1980s. The structure of cities was moulded by the so-called 'citybuilding enterprises', i.e. by the most important industrial enterprises in the planned economy. 
The entire consumer goods and services sector in Soviet cities was underdeveloped until the end of the 1980s. This stunted goods and services sector was dominated by social and, above all, household services, while the area of business services was completely underdeveloped. In the centrally planned economy these service areas were either completely superfluous (e.g. marketing, consulting, advertising and real estate agencies) or certain activities were institutionally integrated within the established structures of enterprises (legal departments, training and continuing education facilities, travel agencies, social services, e.g. child care and health care, wholesalers and logistics, etc.). There were large industrial enterprises in the Soviet Union in which up to 40 per cent of the workers were not engaged in the productive sector but rather in the provision of social service facilities for company employees. Consequently, with the onset of the processes of societal transformation and the collapse of many industrial enterprises, a service and supply vacuum arose. On the fringes of the informal economy a spontaneous, unregulated and extensive business sector, known as maliy biznes (small business), blossomed, which almost instantaneously filled the vacuum and created a completely new area of activity, businessoriented services. At the same time, the maliy biznes sector secured the economic and social survival of large sections of the population. Countless privately owned small to medium-sized businesses sprang up in the previously under-provided trade and services sector.

Retail trade is one of the sectors that - without state planning and regimentation - rapidly reorganized and adapted to the new conditions. The retailing boom in Russia has taken a completely different form to that in the former East Germany, where, since the fall of the Berlin Wall, many oversized shopping centres have been developed on the edges of cities or on greenfield sites in competition with retailers in the city centre. In the first half of the 1990s in Russia, however, the number of kiosks and other mobile trading facilities mushroomed. Whereas there were hardly any supermarkets, hypermarkets, shopping centres or typical American malls, various forms of temporary commercial facilities became a fixed feature within the municipal supply system (Axenov, Brade and Papadopoulos, 1996).

While small and micro retail trade activities have arisen essentially within the informal economic sector, a large number of the businesses in the goods and services sector are former sub-units of Soviet enterprises or the state administration that were stripped off and sold in one of the first larger waves of privatization. According to Rudolph (1999a, p. 10 ff.): the 'activation and flexibilization of the goods and services sector' is characterized by processes that include:

1 Small business start-ups in retailing and manufacturing, most of which should be assigned to the informal sector. 
2 Provision of services made more flexible by the privatization of existing facilities and the transformation of large business units into smaller structures (primarily consumer oriented services).

3 The development of service industries that did not exist as such in the socialist planned economy, e.g. real estate, financial services, business advisory services and management consultancy, marketing and advertising agencies (Axenov, Brade and Bondarchuk, 1997).

4 The legalization of services that were formerly part of the informal economic sector, for example, the transformation of 'Soviet Apartment Exchange Centres' into real estate agencies after the adoption of legislation on the privatization of dwellings (cf. also Vendina, 1994; Vendina and Brade, 1996; Nedvizhimost Peterburga, 1997).

5 The development of service industries through the disbanding of former state enterprises, or through the decision of companies to concentrate on their core activity:

- The externalization of the supply of goods as well as the provision of social and medical services. These functions are taken on by the community or former employees.

- The externalization of security services, computer servicing and support, maintenance functions, research and development functions. ${ }^{6}$ As a rule such companies rent back the premises they previously occupied as part of the larger enterprise, i.e. they operate as subsidiaries, taking on external contracts.

- The formation of holdings, whereby, for example, the finance departments of the former large concerns develop into banks that can act autonomously but remain institutionally tied to the concern. Other such banks have severed themselves completely from the concern and developed into commercial banks.

6 The formation of service industries through the restructuring of state institutions (administration, research institutes, educational facilities) or their reorientation towards market economy services; a multitude of small, privately owned architectural and planning practices have developed out of the large state institutions for spatial, regional and town planning, some of which had over 1,000 employees; similarly, employees of the state universities and research institutes provide various services including consultancy, expert reports, computer services and language courses.

7 The internationalization of the economy, i.e. the expansion of the tertiary sector through the activities of international firms and institutions.

Because state regulatory measures and basic legal requirements, as well as the process of institutionalizing the market economy, were, and remain, insufficiently developed, the process of post-industrial change is occurring, 
for the time being, in a deregulated and informal environment. Thus it is extremely difficult to establish the number of small businesses, or to assess their economic activities. A considerable number of small businesses are not officially registered as they attempt to evade the high taxes and fiscal requirements that would jeopardize their existence. A large part of the population does declare activity in this sector as a secondary source of income; however, it is, in fact, the main source of income for these people. In a sociological survey carried out in September 1998 with 3,340 respondents from 30 administrative regions of the Russian Federation, only 18 per cent of the people surveyed obtained a regular income from their main or official job and 61 per cent stated that they had additional earnings from a second job. Most of these secondary sources of income were in retailing (53 per cent), followed by the marketing and wholesale sector ( 24 per cent) and 'with foreign firms' ( 7 per cent); a further 8 per cent stated other sources (Dokutshayev and Kolesnikov, 1998).

In spatial terms, the typical pattern of distribution of retail trade and services in the socialist city basically corresponded to the administratively determined, hierarchically organized system of higher and lower order centres: from the main municipal centre, through sub-centres in the city districts, to the centres in the micro-rayons (residential centres). The guiding principle of socialist urban planning was the minimizing of daily journey times for the city population. This meant that the workplace and residential areas (the latter including service and supply centres), although separated by green zones, were closely connected and formed respectively a spatial subsystem with extensive self supply and independent road systems (Stadelbauer, 1996, p. 224 f.). There were state-prescribed norms that determined which types of retail, supply and service functions were to be provided in each type of centre. The level of provision was dependent on the number of residents in the respective area, as well as on the hierarchical position in the system of centres, i.e. on the catchment area of centre. The centres were planned and organized according to the socalled complex-concentric principle (Karsten and Janke, 1974).

Under socialist central planning, state (including local authority) institutions had clear priority, while economic necessity, geographical location and spatial structures within cities played only a subordinate role.

Since the abolition of the planned economy, Russia has been attempting to create the structures of a market economy. One of the most important prerequisites for this is the right of property ownership, now guaranteed in the constitution. The following processes are connected to this right:

- the privatization of the economy;

- the withdrawal of the state from its previous role as decision-maker in various areas of the economy and planning;

- the liberalization of prices;

- the creation of a class of independent entrepreneurs. 
This right represents an important prerequisite for the development of business awareness and for the formation of an economically strong middle class, as well as for the growth of entrepreneurial activity, above all in the tertiary sector, and for the slowly emerging real estate market.

The effect of the right of property ownership can be observed in the fact that value is being put on business space. Monetary worth is being placed on the square metre of floor space, to which no value was assigned during the Soviet period. Within the city, a differentiated pricing structure for office as well as residential space is crystallizing. Dependent on industry-specific demands, business management considerations, the image of certain locations, relative location and existing structures within the city have gained considerably in importance.

Under the new conditions of the market economy, the public sector continues to be one of the factors influencing urban development, but its role has been reduced greatly. Indeed, in St Petersburg, as in most Russian cities, the public sector plays a rather subordinate role at the present time, because no legitimate general development plan or other binding town planning regulations exist as yet, which would allow proliferating entrepreneurial activities to be channelled in an orderly and, with regard to urban development, meaningful manner. Rather, individual arrangements and agreements between the city authorities and the companies requiring space tend to predominate (Brade, Piterski and Schulze, 2002).

The public sector does have a certain significance for urban development due to the activities of the privatization authority CACA (Committee for the Administration of City Assets). Besides being responsible for the fiduciary administration, management, and privatization of state and local authority property, this authority determines the location and the scope of private investment, because before any planned investments in business premises or sites can be made, a concept has to be submitted to the CACA. However, if businesses only need space within existing buildings, then they are not subject to checks or regulation by CACA officials.

Furthermore, while property and land can certainly be acquired by purchase, relatively complicated and bureaucratic stipulations apply. A real estate market by Western standards is only slowly forming (cf. Chapter 2 ), so at present the price of land and property also has hardly any influence on the spatial distribution of the goods and services sector.

This situation means that, on the one hand, business people are free to choose between locations that they deem suitable, while on the other, it calls forth bitter competition between businesses for the locations best suited to their company and industry-specific requirements. A further factor comes into play with the entry into the market of foreign companies and investors, who evaluate the advantages and disadvantages of locations using Western understanding and know-how, and thus begin to influence the pattern of distribution of economic activity (Gritcai, 1997). 
It is to be expected that profound changes in the spatial structure of the city will occur in the coming years. Our investigation of the development of the tertiary sector in St Petersburg indicates that new agglomerations of facilities and businesses are crystallizing, from which in turn diverse activities are springing forth, so that the old, administratively determined system of centres will also be forced to change.

\section{Transformation city and post-transformation city: approaches to theory and research}

Within the field of urban studies, a lively discussion is taking place as to whether existing theories or new theories should be used to explain the processes occurring in post-socialist states and to provide prognoses for the future.

\section{Theoretical and research approaches to urban development in the post-socialist states}

If one follows the logic of the socio-ecological theory of urban development, whereby the laws of urban development (non-societal factors are the dominant influence on the structure and development of cities) are deemed to have greater influence than the property relations and political structures specific to the respective society, then one would have to conclude that the transformation from socialism to capitalism should not bring about any major changes in the development of cities in the formerly socialist countries. According to this theory, long-standing development tendencies have simply been modified by the process of transformation (Friedrichs, 1978, cited in Häussermann, 1997). This theory, however, still remains to be proven by concrete empirical research.

The collapse of socialism has been accompanied by a renaissance of modernization theories. Representatives of this theoretical approach speak of 'Westernization' and of underdeveloped societies 'catching up' with the West. In this approach, the post-socialist states are seen to be following the same path to a market economy and political democracy as Western states (Burawoy, 1994). Thus, post-socialist urban development occurs according to the same developmental logic as in the urban regions of Western Europe, albeit a little later in time and at an accelerated tempo. The fact that Eastern European countries are just 'catching up' with the West means that they will go through the same predictable developmental phases. Enyedi (1994) assumes that urbanization in Eastern and Central Europe follows the same model as the rest of Europe - just slightly belatedly - and points to the fact that 'long-term urban processes continued to take place in communist countries of Europe during the last 45 years, that there are therefore fundamental similarities between the Western and Eastern European urban systems' (Enyedi, 1994, p. 58). 
However, critics counter that "national boundaries, ethnic rivalries and political power struggles could well be more important for the major actors than the building of a consensus for democracy and a market economy' (Zapf, 1998). Stenning (1997) believes that Central and Eastern European countries are indeed moving towards capitalism, but the result will not necessarily take the shape envisaged by Western advisers and commentators. It is more likely that cultural differences, national traditions and differences in mentality, as well as historical and geographic factors, could lead to regionally different forms of economic, political and social change.

Those authors who support the idea of the 'catching up' development of post-socialist cities refer to globalization that leads to unification of the major trends of urban development. We have already mentioned growing dissatisfaction with such a view of globalization on the part of those who claim that a substantial degree of regional specificity is applied to the globalization trends (Castells, 1993; Taylor and Hoyler, 2000). Marcuse and van Kempen supervised an international study aimed at answering, among others, the question: 'Is there a clearly visible direct impact of globalization on the internal spatial pattern of cities?' (Marcuse and van Kempen, 2000, p. 2). Even though they did not include the case study of a post-socialist city, their answer is 'No': 'There is ... no standard pattern, no "the globalized city", no single new spatial order within cities all over the world' (Marcuse and van Kempen, 2000, pp. 270-1).

Lichtenberger (1998) also believes that the processes of transformation in Eastern Europe will not run exactly the same course as in the West. This is because unexpected events may arise, some phases may be skipped and other phases may run parallel to one another. Her opinion is that the change of political system has had a profound effect upon all parameters of urban development. With respect to certain indicators she does, however, concede similarities with the North American socio-ecological model. For example, she likens the spatial segregation apparent in Budapest to a 'central crater of poverty'.

Other urban researchers also highlight the importance of unique 'pathdependent' forms of urban and spatial development. This is based upon the reasoning that post-socialist cities are not following a single predetermined path of development, influenced by global factors, but that each city is going its own way, influenced by regional and national economic and political factors. On the one hand, the "theories of different development paths' highlight the long-term effects of historical processes and traditional patterns of behaviour, and so the possible continuity or revitalization of certain phenomena and processes. On the other hand, they attach critical importance to informal, spatially relevant practices in economics, politics and social culture, as well as to the combination of old and new institutional power structures (Matthiesen, 1999). 
The question of whether the countries of Eastern and Central Europe are merely catching up, or whether they are developing their own post-socialist structures has not yet been answered adequately either by transformation specialists or by urban researchers. This is unlikely to happen within the foreseeable future, as most countries are still in political, economic and social transformation. Furthermore, there is no historical model to which these processes can be adequately compared. Western models and other tried-and-tested theories have not had the desired results and could not be successfully transferred to the situation in Eastern Europe. They all show a 'lack of sensibility to the historical and geographical peculiarities of the social system' (Stenning, 1997). At the moment, it is impossible to provide a comprehensive explanation of the interconnections and relationships between the various social processes that are currently taking place throughout Central and Eastern Europe. It is, however, realistic and possible to undertake an assessment of individual phenomena that characterize the transformation phase and the current state of urban development in the post-socialist countries.

Using empirically based studies, scientists now have the one-off chance to investigate the processes of the transition to pluralism and a market economy and to analyse how spatial relations are affected by the changing structure of the economy.

The following questions are of interest for the study of the cities of Eastern Europe:

- Under the new social conditions and under the influence of global processes, what chances do the cities of Eastern Europe have of being competitive in the European network of metropolitan centres?

- How do the spatially relevant tertiarization processes of the transformation phase differ from both the state-controlled urban development of the socialist era and the urban development processes of Western market economies?

- What effects do these processes have upon urban space? What structural changes are taking place within the city under the new political and economic conditions?

\section{What is transformation?}

Vast discussions on the origin and mechanisms of post-socialist change have resulted in the implementation of several theoretical and methodological approaches. The different terms used to describe the changes taking place in the post-socialist societies of Eastern Europe generally reflect the discussions on which theoretical approach allows the best description of reality. Distinctions between the terms 'transition', 'restructuring', 'reformation', 'transformation' and others help some authors to 
stress their view on the character of the processes being described (see, for example, Andrusz, Harloe and Szelenyi, 1996; Pickles and Smith, 1998; Kovacs, 1999). In order to make our understanding of 'transformation' clear, let us comment on the usage of certain terms and related approaches.

Several authors have stressed the limitations of using the term 'transition' in relation to the processes being described (see for example Stark, 1992; Stenning, 1997; Stahl, 1998; Hirschhausen, 2001). The main tenet of their arguments is that the term 'transition' assumes the existence of some predefined end-state to be achieved as the result of changes (Stark, 1992; Stenning, 1997; Dingsdale, 1999). Hirschhausen states also that "transition" is a misleading concept, as it defines an objective whereas the way to get there still remains unclear' (Hirschhausen, 2001). According to this view, 'transformation' is a much broader, multidimensional and multidirectional systemic change that might lead to diverse and not fully predictable results.

'Restructuring' is viewed as a more economic type of structural development, and relates to an object attaining another quality (economy, company, etc.) (Lovering, 1989; Stenning, 1997, p. 151). Usage of the term 'reformation' refers to the application of certain uniform reform strategies to the conditions of post-socialist Eastern Europe, in order to obtain predictable results. Some authors warn of the inadequacy of transferring reform concepts and strategies from other parts of the world to the postsocialist states (Streit and Mummert, 1996, p. 4). In different countries and even within one country use of the same set of reforms has led to different economic and societal results. This point is also used as an argument against usage of the term 'transition'.

There are various definitions of 'transformation', the most comprehensive probably being the one given by Fassmann: 'the extensive, and from a historic perspective, extraordinarily fast changes in the political, economic and social structures of the formerly socialist societies of Central-East and East European, since the end of the 1980s' (Fassmann, 1997).

Following the many authors, we consider the term 'transformation' to be the most appropriate to define the changes that took place in the postsocialist countries of Europe and the former USSR (Union of Soviet Socialist Republics). In the context of discussions mentioned above, we would treat transformation as:

- a not purely economic process somewhat similar to restructuring and heavily influenced by a variety of social, cultural, political, etc. dimensions that might modify or even undermine economic restructuring;

- not identical to modernization/Westernization since it may result in specific forms and structures; 
- not really a transition from some known point to another predictable one.

In stating this, we are far from rejecting the presence of all the processes mentioned. We consider each of them to have a certain place in the systemic transformation with which we are dealing, albeit not in an exhaustive manner. So, in an attempt to be more specific than Fassmann, we assume that transformation is a multidimensional and multidirectional systemic change in post-socialist societies based upon a general modernization trend, which may lead to diverse results that vary between societies. We share the opinion that the core distinction of transformation lies not so much with the goals and results of the process but rather with the unique starting point - socialist societal structures.

\section{Is transformation over?}

Recently the idea that in most of the post-socialist countries transformation is over has became the focus of transformation debates in the West. Economists were the first to introduce this idea (for example Hirschhausen and Waelde, 2001; Hirschhausen, 2001). After analysing different dimensions $^{7}$ and layers ${ }^{8}$ of transformation, they conclude that all of the formerly socialist states have either generally reached the goals, or now represent distinctly different entities in qualitative terms. Stressing the fact that transformation has led to somewhat different results in different countries, these authors consider comparison relative to the situation at the outset of the process to be the best criterion for evaluating the results of transformation.

In their analysis they cite two facts as evidence that the process of transformation has come to an end. First, the economy is no longer determined by the institutional structures inherited from socialism: 'The common characteristics of post-socialist systemic change have disappeared and new, different forms of economic systems are stabilizing, creating a systemic irreversibility' (Hirschhausen, 2001, p. 12). Second, the variety of economic, social and political paths of development observed in different states in the late phase of transition allows them to state that "the "end of transformation" implies that it is no longer suitable to apply identical economic policies to the countries of the region' (Hirschhausen, 2001, p. 15).

We have no intention of debating this statement with regard to the whole post-socialist macro-region. We doubt that it is accurate even to state that transformation has come to an end in the whole of Russia. ${ }^{9}$ Like many other large, diverse countries or regions in the world, Russia does not present uniformity in terms of the spatial dynamics of economic development. Within Russia, one can observe different regions, where the economy may be characterized as predominantly post-industrial, industrial or even pre-industrial (Gritsai, Ioffe and Treivish, 1991, Smirniagin, 
Livshiz and Novikov, 1994). When one speaks of post-industrial Western Europe, one means that a post-industrial stage of development has been reached by some leading areas, but by no means all regions. In Russia, there has been debate on whether the leading administrative territorial units such as Moscow and St Petersburg have entered a post-industrial stage of development (see, for example, Axenov and Vendina, 1999). We believe that transformation in St Petersburg, one of the leaders in the Russian reform process, could be considered complete: modernization has occurred, and the city could be treated as a part of the global urban and economic system.

Although we can observe a new stage in the discussion of transformation ushered in by the idea of a new phase of post-socialist processes, this discussion has inevitably inherited some major points of controversy from the previous stage, as well as producing some new questions. The main question, which still remains a matter of debate, is what should be considered the result of transformation in economic and social terms, regardless of whether it has already been achieved or not. Does transformation result in a society that has finally reached the same paths of development as societies in the West and other globalized parts of the world $?^{10}$ Or does it produce something different? If so, what are the peculiarities that would allow one to describe post-transformational uniqueness? In other words, what are we dealing with at the end of transformation Westernized, modernized and globalized society or post-transformation society, a specific form clearly distinguishable from the former?

A more specific, but for us no less essential question arises about the spatial dimension of transformation and post-transformation. Have any specific spatial forms and structures emerged during transformation? ${ }^{11}$ If so, what is their origin and how might they be integrated into the global context? In our opinion, by answering this specific question one might get closer to a more general theorization.

Our present research is by no means aimed at answering all these questions in full. Our ambition is to contribute to this discussion with the results of our applied study. It being generally agreed that in the case of Russia, or at least St Petersburg as the focus of our study, transformation in the sense discussed above is over, and has given way to a new stage of development, we base our study on the following assumptions. First, although the major trend of modernization can be witnessed as an underlying process in Russia and St Petersburg, transformation as a unique time-space process might have produced specific spatial forms, different from those of the West. Second, the uniqueness of these spatial forms might originate both from conditions peculiar to the socialist era and from the transformation process itself. Third, these spatial forms might have produced the new urban spatial structure that we call the posttransformation city. 


\section{What is transformation and post-transformation urban space?}

Studying the spatial structure of St Petersburg during the last 15 years, we observed three stages of development. These stages differed from one another in at least five dimensions - dynamics of spatial structure, regulation of restructuring, measure of involvement in the global context of modernization, property issues and spatial saturation. We have provisionally named these three stages as the 'socialist city', the 'transformation city' and the 'post-transformation city'. What are the basic differences between these stages of the city's spatial development?

In terms of the five dimensions mentioned, the spatial organization of the 'socialist city' was distinguished, first of all, by the most conservative dynamics of spatial structures on all spatial levels. ${ }^{12}$ The same prescriptive planning norms and principles had been in use for decades. The very narrow set of agents involved in the regulatory process was a significant factor behind the slow rate of change in the spatial structure of the city. Almost all regulatory agents were integrated into or mediated by the structures of the state government. No location decision could be taken and implemented without state involvement or outside state regulatory norms. Realization of all market or quasi-market location requirements was mediated by the decisions of state agencies. And lastly, socialist urban space was part of the national or socialist economic and social system, which was so protectionist that it was almost completely isolated from the economic and social context of the West. As a result, a socialist city presented distinctly different spatial structures from those in a Western city (see, for example: French and Hamilton, 1979; Bater, 1980; French, 1995). Kostinskiy (2001) outlines the following major features of a Russian 'socialist' city:

- state control over urban land use;

- complete absence of private property in land;

- state control over the housing economy (financing, realization of development, distribution of housing stock and its management);

- wasteful land use, resulting from absence of land rent under socialism;

- centralized organization of services and supply;

- the underdevelopment of services and locating of urban amenities quite regardless of the structure and volume of market demand;

- the domination of public over private transport;

- the exclusive importance of ideological symbols in the urban environment, including the monumental architectural style of public buildings, underlining the emphasis placed on the special importance of the urban centre.

So land and most real estate ('commercial' properties, public buildings and housing) belonged to the state. The limited amount of cooperative ${ }^{13}$ 
and 'personal' ${ }^{14}$ property did not exert much influence on decision-making. Probably one of the main features of the socialist economy was the shortage of available consumer goods and even major industrial supplies. In terms of urban space, this was expressed in the very low level of retail and service space per capita. The number of outlets in the retail trade and services sectors was several times lower than in a Western city.

The 'transformation' process brought about complete change in each of the dimensions relating to the spatial structure of the city. According to Kostinskiy (2001), the transformation of the spatial organization of Russian cities after socialism has resulted from three main processes:

1 The spontaneous development of private business and the increase in the number of small and medium-sized enterprises.

2 The diminishing role of the state both as regulator of socio-political life and owner of economic enterprises.

3 The development of urban government (at both city and intra-city levels), whose purposes differ from those of previous regional (oblast) and state authorities.

At this stage, the pace of the restructuring of space within the city reached its highest level, especially on the micro- and meso-scales. New ways of utilizing urban space and real estate emerged in certain areas and quarters, and in individual locations and buildings. Not only did the emergence of new spatial forms and locations contribute to the very rapid rate of spatial transformation but the pace of change within these new local structures was higher than at any other stage. The degree of administrative regulation was at its lowest during this period. Administrative regulations issued at this time were contradictory and strategically unpredictable, and thus were inevitably harmful to emerging businesses. Market forces seemed to become the only regulator of the spatial distribution process. ${ }^{15}$

In terms of global involvement, the transformation city was opened up to the processes of modernization and globalization, this led to spatial adaptation because the spatial structure and forms inherited from the socialist city in no way met the requirements of a modernizing and globalizing economy and society.

Our point for further discussion is that the essence of transformation in urban space lies in the process of saturating space with new forms and structures that could meet the challenges of the new globalized economic and social context. ${ }^{16}$

The transformation period was marked by rapid changes in property legislation. The emerging business structures had to adapt to these changes. At different stages of transformation private actors generally, certain private business forms, private actors in certain industries, and internationally 
owned business structures were not allowed to operate in the Russian and St Petersburg economies. Under loose and arbitrary state regulation, characterized by constantly changing and contradictory legislation, mass privatization of state property constituted the major structural aspect of transformation. Although private ownership of land was approved by the adoption of the new Russian Constitution in 1993, the absence of corresponding laws meant that in practice, the private ownership of land was not permitted in most Russian cities for a long time. ${ }^{17}$

Since the first years of the twenty-first century, one can observe a new stage that we call the 'post-transformation city'. The dynamics of change in the spatial structure have slowed up, and there has been a distinct shift to a new scale. The most rapid changes now take place on a macro-scale, relating to the city as a whole and its largest structural parts, rather than on the micro- and meso-levels. New locations emerge very rarely, and when they do, it is mainly in the context of the city's macro-development - in newly developed or redeveloped areas - due to the adoption of new legal regulations, etc.

The state and local authorities have become the main regulators of the location process in the city once again, and the regulatory mechanisms are being adjusted to the requirements of the new economy and society. ${ }^{18}$ In the main, this adaptation follows a predictable trend: the authorities are becoming responsible for the results of their regulatory actions. A balance between the involvement of market forces and governmental regulation in shaping urban space has been generally achieved. Gradually, the rules are becoming more uniform and strategically clear to the actors involved. Privatization has generally come to an end, major business objects and locations have been distributed between new private owners, and a process of market redistribution takes place on a legal basis. This redistribution of the market among new owners has become the leading process of the post-transformational stage, as opposed to the privatization of the previous stage. To a certain extent the transformational process of spatial saturation has come to an end - physical accessibility of basic goods and services is no longer an issue. The spatial and structural redistribution of the market has become the major concern of business.

Table 1.1 summarizes the features of these three stages. Most of the changes discussed in the above paragraphs will be outlined in more detail in the course of the further discussion of our research.

\section{Research objective}

Thus we suggest that, in case of St Petersburg, we are dealing with the emergence of a new stage of development that could be called the posttransformation city. This stage was reached as the result of the extremely rapid effects of global modernization trends on the structure of the socialist 


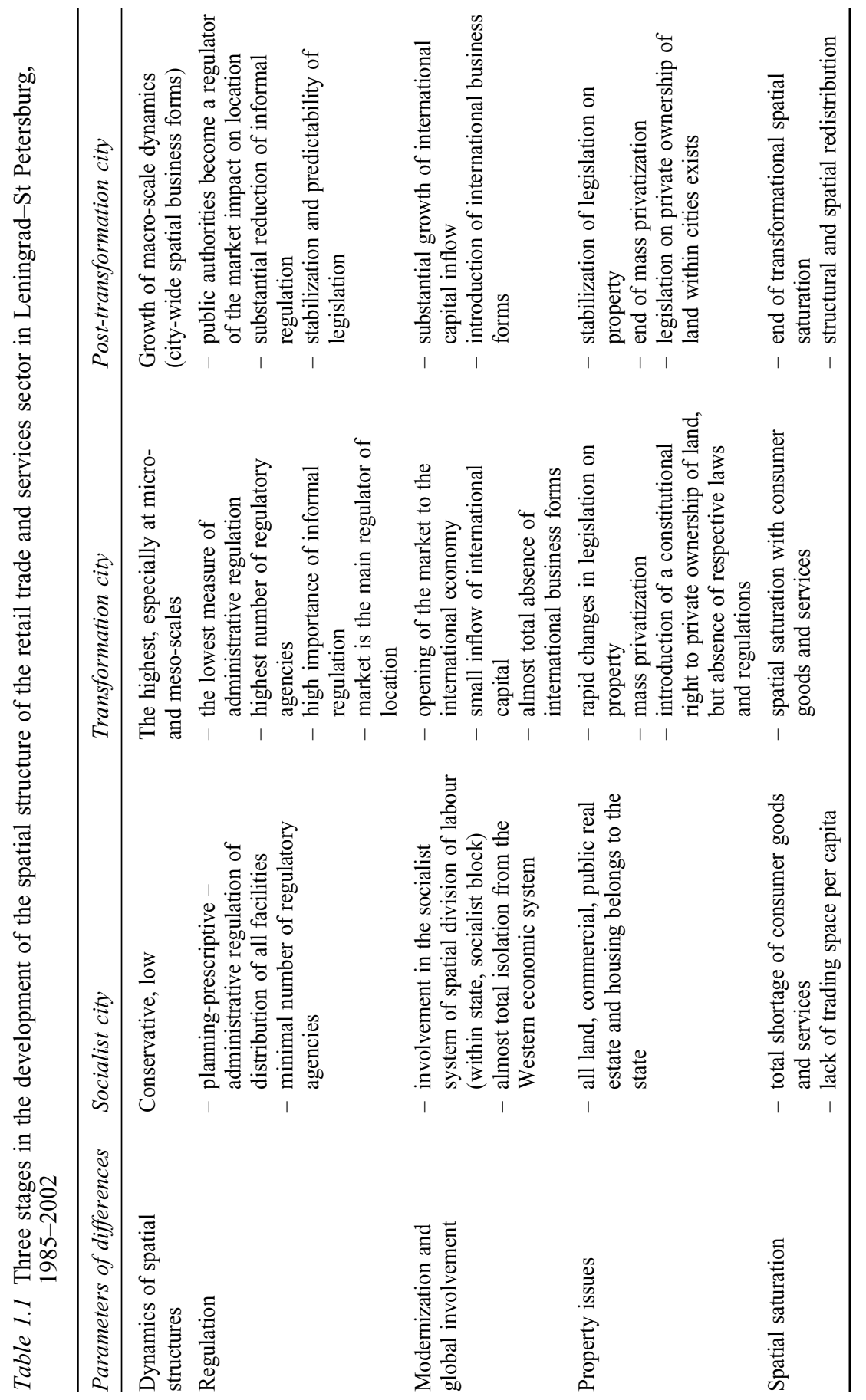


city. Applying one of the major questions of the transformation debates to our research field, can we say that the term 'post-transformation city' is identical to 'modernized city'?

Several reasons lead us to believe that the post-transformation city should have certain peculiarities that distinguish it from Western cities at the same stage of modernization. First, modernization was not the only process that took place during transformation. At the very least, transformation also included the process of restructuring/adaptation of the old socialist economy and society. This particular process was never experienced by Western cities. Second, most students of transformation highlight its extraordinarily high pace in comparison to Western modernization. Some material and social features that characterized certain stages of Western modernization simply could not appear in such a short space of time. Third, the end result is not only influenced by the speed of the change process. Many authors consider that Moscow and St Petersburg, for example, could reach the postmodern (post-industrial) stage while missing out certain stages of development through which Western cities have passed. These stages are described in terms of 'late capitalism', 'consumption society', etc. (see discussions in: French, 1995, p. 203; Stenning, 1997, p. 153; Rudolph, 2001, p. 29).

So in our research we must assume that, along with traditional Western structures and forms resulting from modernization, some features specific to post-transformation urban space should emerge. These specific spatial forms and structures have at least two possible roots: first, the continuing presence of specific material socialist structures; second, a type of specificity that might derive from the process of transformation itself. Its uniqueness, which is described above, might have produced certain specific forms of spatial adaptation that might have been adopted by the posttransformation structures.

The features characterizing the spatial organization of the socialist city are well described in Western literature (Harris, 1970; Andrusz, 1984; Bater, 1980; Bater, 1996; French and Hamilton, 1979; French, 1995). Our challenge therefore, is to contribute to the description of the spatial processes and structures that are attributed to the transformation stage of city development and to suggest certain approaches to defining and studying post-transformation urban space. Our further discussion focuses on three major aspects. First, we have particular interest in the spatial dynamics of the city under transformation. Second, we compare changes in spatial forms and structures in St Petersburg with the processes that take place in Western cities. Specific forms and phases of spatial development during the transformation and post-transformation periods are of major interest to us. Third, we study the impact of specific transformational and post-transformational spatial forms upon the restructuring of the spatial structure of the wider city. 
28 Post-industrial vs. post-socialist

In summary, our research objective involves three major questions:

1 What are the spatial processes connected to transformation and posttransformation in St Petersburg after the end of socialism?

2 What factors and actors contribute to these processes?

3 What new spatial structures emerged during these stages of the city's development? 


\section{Changes in the functions of St Petersburg as a prerequisite for structural change in the city}

St Petersburg is one of the youngest metropolises in Europe, but one with a highly individual and varied history. St Petersburg, Petrograd, Leningrad, St Petersburg: no other European metropolis has in the course of its existence experienced so many changes of name as this city, name changes that have been accompanied each time by extensive changes in the functions of the city and its structure.

Three essential stages define the evolution of the city:

1 Its development as a financial centre, as well as a city of world rank in the spheres of commerce and culture prior to the early twentieth century.

2 Its redefinition as the second largest industrial centre of the Soviet Union.

3 Its transformation into a modern, multifunctional, economic centre in Eastern Europe since the beginning of the 1990s.

\section{Geographical background}

St Petersburg is situated in north-west Russia, on the Neva Delta, which flows into the Gulf of Finland. With around 5 million inhabitants, St Petersburg is the largest city lying on the Baltic Sea. Its geographical position is almost exactly at the intersection of the 60th parallel of northerly latitude and the 30th meridian of easterly longitude, making St Petersburg the most northerly city with one or more million inhabitants in the world. Among European metropolises, it takes fourth place, behind London, Paris and Moscow. Considering in particular its foreign trade relations with Western Europe, St Petersburg - of all the cities in Russia - enjoys the most favourable geographical position (see Figure 2.1).

The north-west of Russia is, on the whole, sparsely populated. The closest population centres, Novgorod (220,000 inhabitants) and Pskov (207,500 inhabitants) are 190 and 290 kilometres away respectively. Moscow and St Petersburg are separated by around 700 kilometres. The density of the network of towns and cities is significantly higher in the 


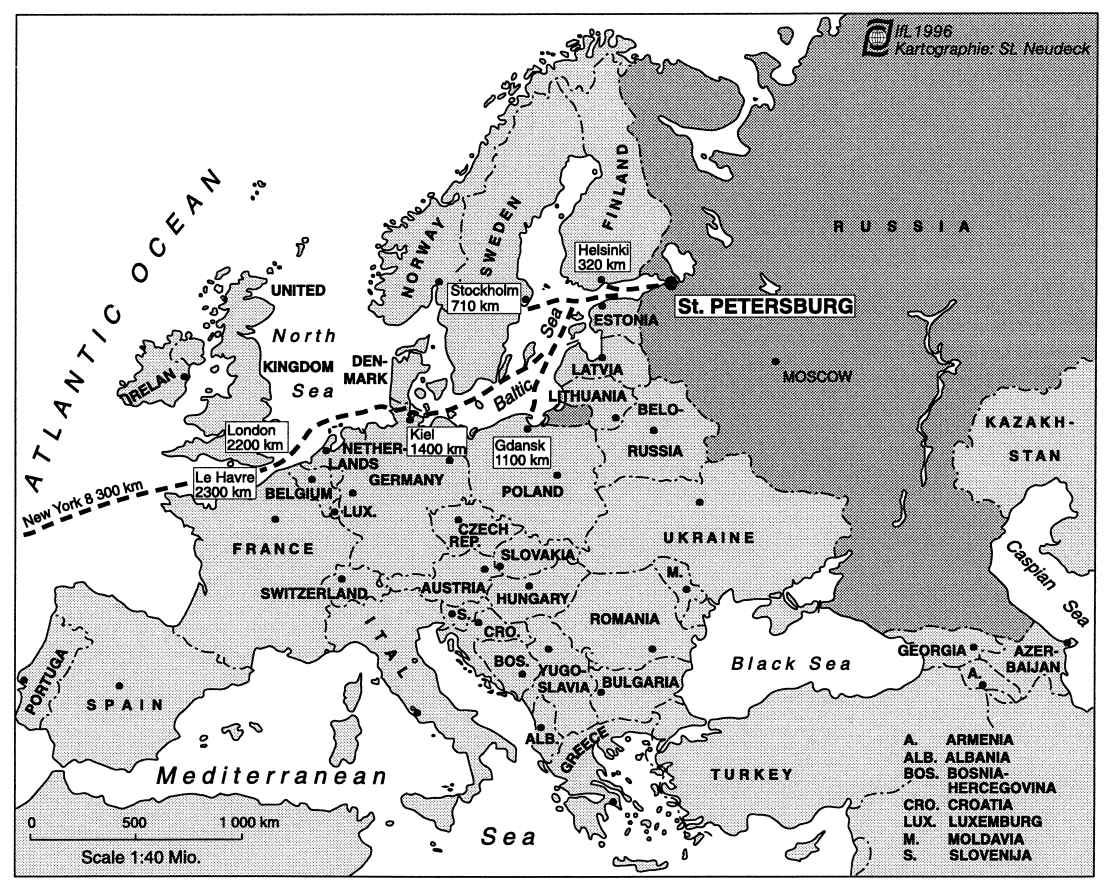

Figure 2.1 The position of St Petersburg within Europe

Source: Brade, 1994a.

western part of the Leningrad oblast, ${ }^{1}$ especially around the city of St Petersburg, than in the eastern part. The population density of the western districts (rayons) is 50 inhabitants per square kilometre, that of the eastern districts hovers at under 8 inhabitants per square kilometre. The towns and cities are situated, in the main, along radial axes of settlement and transportation, which lead in a star-shaped pattern to the core area. The Neva - the 74-kilometre-long and 1,300-metre-wide outlet of Lake Ladoga - forms the start of a well-developed waterway (connected by canals with to the hinterlands of the Upper Volga), which as early as the eighth or ninth century was carrying trading ships along the famous route 'from the Varangians to the Greeks', that is, from the Baltic to the Black Sea via the river system. As a result, St Petersburg signifies, for the whole of Russia, the origin for various economic activities from and to Europe.

\section{The opening-up of Russia}

The city was founded in 1703 by Peter I (see Figure 1). Although this site offered the most unfavourable natural conditions for human settle- 
ment, its geographical position induced Peter I to build the capital of the Russian Empire here, a place unaffected by Russian traditions, far removed from the patriarchal order of Moscow and as close as possible to the West. In its western part, Russia, the largest state in the world, possessed no access to the world's oceans and thus to the markets and most important economic centres of Western Europe and overseas. The window to Europe was opened up through the conquest of territory occupied by Sweden on the Gulf of Finland, and through the subsequent construction of a port. This allowed two fundamental objectives of the reform policies of Peter I to be realized:

1 Access to the world's oceans and achievement of the status of a maritime power.

2 The Europeanization of the Russian Empire.

The economic development of the new capital city was shaped by its predetermined functions:

1 To develop as a recognized, modern, European centre for commerce and industry.

2 To act as a protective shield for the hard-won 'Gateway to Europe', and at the same time as a point of departure for further territorial claims in the West.

3 To emerge as a strong centre that would act as the main impulse for the spread of a Western-style progressive culture in Russia (Brade, 1994b).

\section{Development into a European metropolis}

The economic advance proceeded at breakneck speed. Large state manufactories and enterprises quickly arose for the production of military goods and the construction of ships, and also to satisfy the demands of the nobility and the official classes. The first foreign ship landed in 1703, and as early as 1726 St Petersburg was counted as the largest centre of maritime trade in Russia. The Tsar devoted much attention to the promotion of the applied sciences, such as the natural sciences, law and engineering, as well as military education.

The city bloomed into a rich cultural centre, especially under the successors of Peter I. The famous Hermitage was established in the Winter Palace by the Empress Katherine II, who originally came from AnhaltZerbst in Germany. By the end of the eighteenth century the city had 220,000 inhabitants, an extraordinarily notable size by the standards of the time (see Figure 2.2). St Petersburg had surpassed Moscow and joined the ranks of the Western capitals, London, Paris and Vienna. It was counted as one of the court capitals of Europe, which attracted the nobility - and 


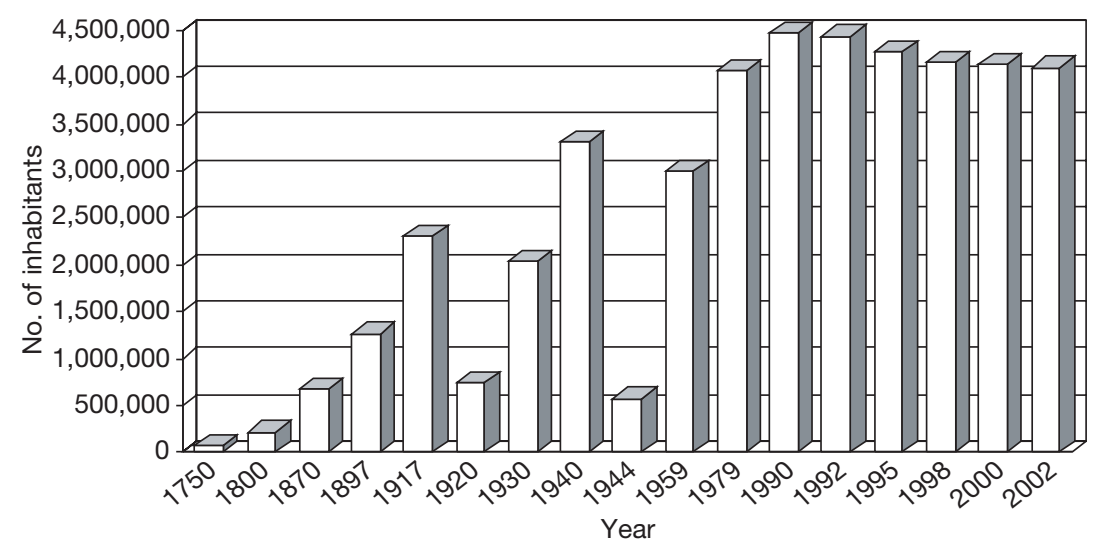

Figure 2.2 Population development of St Petersburg

Source: Entsiklopedicheskiy spravochnik: Sankt-Petersburg - Petrograd - Leningrad (Encyclopaedia: St Petersburg - Petrograd - Leningrad) Moscow, 1992. Rossiskiy Statisticheskiy Yezhegodnik 2003 (Statistical Yearbook of Russia, 2003). Goskomstat Russia (2003), Moscow.

broad sections of the intelligentsia and merchant classes - from both Russia and Western Europe (Faszinierende Städte, 1993).

The onset of industrialization in Western Europe in the nineteenth century led to a further economic upsurge in St Petersburg. Alongside the state enterprises, in which the armaments industry was mainly concentrated, large private enterprises in metal working, textiles, chemicals, light industry and food industries also sprang up with the participation of both Russian and foreign bank capital. These enterprises were involved, above all, in processing raw materials imported from Europe and overseas (such as coal, iron, cotton and rubber) for the rest of Russia, where there was still very little industry.

With the emergence of a capitalist economic structure, the city developed into a recognized financial centre. The propitious geographical situation, the convenient transport network and the cheap labour force were factors that stimulated the influx of capital. All the renowned domestic and foreign banking houses and trading companies had branches on the Nevskiy Prospekt, the most important commercial street. Foreign capital, especially German, French and American, flowed into St Petersburg. Many St Petersburg enterprises operated with foreign capital. Among the Western companies that set up subsidiaries in St Petersburg were firms such as AEG, Westinghouse, Singer and Siemens - and, for example, the Nobel Brothers, whose activities in Russia laid the financial groundwork for the later Alfred Nobel Foundation. The largest Western banks - the Rothschild banking houses of London and Paris, the Dresdner Bank, the Deutsche Bank, as well as the largest American banking houses - provided 
the common stock capital of the leading St Petersburg banks. At the turn of the century St Petersburg was one of the leading economic and social centres in Europe, with a population of 1.3 million, of which 13 per cent were foreigners. St Petersburg had become a hub between East and West (Plan S.-Peterburga, 1901).

This phase, in which the economy, as well as integration and exchange with the whole of Europe, flourished, was also a time marked by internal political difficulties, which finally led to the downfall of the tsarist system of rule. The first signs of a change in the significance of St Petersburg became apparent at the end of the nineteenth century. The Russian influence in the economy, science and culture was expressed more strongly, while the previously formative foreign influence was suppressed. An expression of this on the eve of the First World War was the renaming of the city as Petrograd, because St Petersburg sounded too German.

\section{The Iron Curtain closes the 'window on Europe'}

The October Revolution of 1917 resulted in a decisive change in the function and significance of the city. In its wake the capital city function was transferred to Moscow a year later. The population suffered a drastic reduction from 2.3 million in 1917 to 740,000 three years later (see Figure 2.2).

Leningrad - as the city was called from 1924 - was one of the cities (not just in Russia but in the whole of the former Soviet Union) that after the October Revolution lost almost all the conditions for further development that had existed previously (Litovka, 1993):

1 Its essential function as the opening to Europe and door for European influences to enter Russia, was no longer in the interests of the central government in Moscow. The 'window on Europe' was closed with an 'Iron Curtain'.

2 Leningrad lost its significance as an international import-export port. The value of its favourable geographical position declined with Soviet economic autarky. Certain industries were cut off from their most important sources of raw materials. They had to adapt to domestic fuel and raw material sources, which at that time could not be exploited either in sufficient quantity or in the requisite quality, and which often had inherently longer transport routes or higher transport costs. Thus, while pre-revolutionary St Petersburg imported coal from England, iron and metals from Germany, Belgium and Switzerland, cotton from the United States, etc., under Soviet conditions the local economy obtained peat from the nearby area, coal from the Donbas, metals from the Ukraine and the Urals, and cotton from Central Asia.

3 The city lost its function as the most significant financial centre in Russia and one of the most important financial and commercial centres in Europe. At the same time the flow of foreign capital was broken off. 
4 Leningrad lost a considerable portion of its previous market, not only in former territories of the Russian Empire such as the Kingdom of Poland, the Baltic provinces and the Grand Duchy of Finland but also in the countries of northern Europe.

5 In addition to the loss of capital city status, the city also had to forego other functions, such as its previous role as the leading economic, transport, distribution and administrative centre within Russia. The seat of the Academy of Sciences was transferred to Moscow. Leningrad was reduced to the administrative centre of a relatively insignificant area, Leningrad oblast.

The further development of Leningrad concentrated essentially on its new main function: The city was supposed to be the starting point for and centre of the economic development of the north and north-east of European Russia. From a European metropolis with a broad spectrum of functions, an important Soviet industrial centre developed.

In the following period a massive industrialization process was set in motion with a high degree of specialization and concentration of production processes. Between 1970 and 1989, for example, mechanical engineering and metal working increased from 30.9 per cent of industrial production in St Petersburg to 52.7 per cent, while light industry dropped from 26.1 per cent to 15.5 per cent (see Table 2.1). Gigantic industrial establishments employing between 10,000 and 40,000 workers were created in the processing industries, particularly in metal working, i.e. in heavy and specialized mechanical engineering, and in the branches of industry oriented toward the military.

Leningrad advanced to a Soviet armaments stronghold. At the end of the 1980 s, 80 per cent of the large enterprises in the city of Leningrad were oriented towards the military-industrial complex and 25 per cent of the armaments production of the entire Soviet Union were located within the Leningrad Region alone (city and oblast) (Litovka, 1993).

Additional industrial branches that developed in the Soviet years were the electrical industry and the chemicals industry based on the oil shales of Estonia and the petroleum of the Volga region. The consumer goods industry had a relatively subordinate significance, with the textile industry having the greatest importance, as a result of the existing historical infrastructure and production facilities.

After the Second World War and the reconstruction of the industrial sector, changes in the industrial structure occurred. The extreme specialization of industry as a whole and of individual branches led to a deformation of industry and monostructure (an extreme specialization of industry in a city or in a region, in which mostly only one branch was developed) in the most important industrial sectors. Specialized mass production also accounted for huge rises in physical output, which amounted to about 
Table 2.1 Proportion of industrial production in selected industries

\begin{tabular}{lrrrrrrrr}
\hline Industrial branch & 1970 & 1985 & 1989 & 1993 & 1994 & 1996 & 2000 & 2002 \\
\hline Electrical energy & 1.7 & 1.9 & 1.9 & 13.6 & 16.9 & 22.2 & 7.9 & 10.6 \\
Chemical industry & 6.9 & 5.5 & 6.1 & 4.6 & 4.6 & 4.1 & 1.35 & 2.6 \\
Machinery, metal & & & & & & & & \\
$\quad$ working & 30.9 & 49.3 & 52.7 & 36.8 & 36.5 & 35.4 & 33.9 & 33.7 \\
Timber process- & 3.4 & 2.9 & 3.1 & 3.4 & 3.3 & 2.9 & 2.8 & 2.7 \\
$\quad$ ing & & & & & & & & \\
Light industry & 26.1 & 17.0 & 15.5 & 9.1 & 5.1 & 2.8 & 2.4 & 2.0 \\
Food products & 19.6 & 14.0 & 13.3 & 17.9 & 19.3 & 18 & 39.1 & 36.2 \\
\hline
\end{tabular}

Sources: Entsiklopedicheskiy spravochnik, 1992; Kratkiy statisticheskiy spravochnik, 1995, 2000; Strategic Plan, 1998; Rossiskiy Statisticheskiy Yezhegodnik, 2003, p. 344.

35 per cent during the five-year plan 1966-70 (Sankt-Peterburg $v$ zerkale statistiki, 1993).

All resources for development in St Petersburg and all other functions were subordinate to the designated function of the city as a leading Soviet industrial and armaments centre. A comparison with Moscow illustrates this: in the capital city the share of workers in the industrial sector was deliberately reduced, while in the areas of non-material production it was increased according to plan. In Leningrad, however, industrialization acquired irrational proportions in the last three decades of the Soviet Union and, as a result, the once multifunctional city was transformed into an 'ordinary' industrial centre. The drive for industrialization even took hold in the zone of historically and culturally valuable parks and castles that surrounds the city (Agafonov and Isljajev, 1995, p. 95). Leningrad was second behind Gorki (now Nizhniy Novgorod) in terms of the ratio of industrial employment to total employment (Litovka, 1995, p. 100).

Related to the expansion of industrial production was the establishment of scientific and research institutes, particularly linked to the armaments industry. In 1990, some 12 per cent of the scientific and research institutions of the Soviet Union operated in St Petersburg (Karger, 1987). Leningrad had evolved into a technical-scientific centre.

The government's policy of forced industrialization drew a massive stream of labour from all the republics of the Soviet Union, and the population of Leningrad increased rapidly. Interrupted by the Second World War and especially by the devastating 900-day siege from 1941 to 1944 by German troops, the number of inhabitants nevertheless continued to rise (Figure 2.2). Even today the proportion of non-Russians remains about 11 per cent of the population. At the beginning of the 1990s about 70 per cent of inhabitants had not been born in the city. Now, as in Soviet times, the birth rate lies well below the national average (Entsiklopedicheskiy spravochnik, 1992). 


\section{St Petersburg as a post-socialist metropolis}

\section{St Petersburg - once again the gateway to the world}

The Soviet Union ceased to exist in 1991. The city - which once again bears its old name, St Petersburg - stands at the beginning of a new stage in its development, which is characterized by the gradual introduction of the structures of a market economy and by a new geopolitical situation in the Baltic Sea region.

The prominent role of Soviet Leningrad as an economic centre was not restricted to the north-west, but extended throughout the Russian Socialist Soviet Republic (SSR), to the Baltic republics and Byelorussia. Within the monopolistically structured planned economy, economic interdependencies had developed between St Petersburg and these regions during the last decades of the Soviet Union. The breakdown of the Soviet federal state and the collapse of socialist regulatory mechanisms at the beginning of the 1990s meant a fundamental transformation of the economic and political functions of St Petersburg. The lifting of the Iron Curtain and the accompanying end of political and economic autarky presented the metropolis of 5 million inhabitants with excellent opportunities - in comparison with the other Russian regions, including Moscow - to attract the attention of foreign investors in particular. St Petersburg had already made a name for itself in the eighteenth and nineteenth centuries that had less to do with its status as the capital of Russia than as one of the leading economic, financial and cultural metropolises of Europe. The traditional close connections to Western Europe, the European flair that shaped the image of the city and its cosmopolitan air meant that, once St Petersburg was reopened as a 'main trade gateway', it seemed much closer and more familiar to foreign investors than far-away Moscow, which represented the centre of Soviet power in the twentieth century.

At this time as well as in the following years, St Petersburg was, with respect to foreign investors, more open than other regions, especially Moscow. The city was quicker and less bureaucratic than elsewhere in granting permission and creating the conditions for a wider range of entrepreneurial activities, through which it hoped to achieve many impulses for general development, multiplication effects (e.g. developing infrastructure, attracting further investors and capital expenditure), and above all, a thrust of innovation in all areas of society especially the economy. If today Moscow outstrips St Petersburg as an economic boom town, it is by reason of its central location in the country, with convenient rail and highway links to all of the remote regions of this huge country, by reason of the above average purchasing power of its 10 million inhabitants and, last but not least, by reason of the easy but necessary access to indispensable sources of information, and to decision makers in the political and economic centre of power. Thus St Petersburg's chances of 
becoming a regional metropolis of European class in Eastern Europe have not diminished. Yearly analysis of the Russian federal subjects according to their attractiveness for investors shows St Petersburg consistently occupying one of the top rankings, particularly with respect to investment potential. $^{2}$

\section{Strategic considerations for the development of St Petersburg}

The far-reaching transformation processes of the 1990s led to fundamental changes in the political and institutional framework for urban development in Russia. Since 1991 the gradual introduction of self-government for local authorities has, for the first time, given local authorities the right to own property and independence in their financial and planning-related affairs. However, thus far the self-governing local authorities have found it difficult to achieve their objectives. This is due to the generally weak economic base of the local authorities, the still poorly defined boundaries between the areas of competence of the various political levels, and unresolved issues relating to the allocation of property rights for former socialist state-owned property. Further conflicts result from the continual disputes over the financial transfers from the federal and regional administration to the local authorities.

The situation of St Petersburg is quite different in this respect from that of other cities. The city is both an autonomous local authority administrative unit (munizipalnoje obrasowanije) and a federal subject equal in status to the republics and regions (oblasti). Thus one administrative level is cut out, reducing the potential for conflict situations because St Petersburg has at its disposal the local authority and regional budgets, whereas the allocation of finances to the local authorities is normally the responsibility of the administration at the level of the federal subject.

Regional and local actors exert a strong influence on urban development in Russia. Besides politico-administrative decision-makers from both the regional and local levels, lobbyists, local interest groups representing different sections of the public, small businesses and the large companies and financial institutions all play a significant role. The direction of urban development is increasingly determined by informal, non-institutional processes. Various interest groups connected with these processes critically influence decisions on the promotion of certain functions, and the shaping of urban space.

Lively discussions on the future development and function of the city were already being conducted at the outset of the state-led processes of transformation, at a federal as well as a local level. Several conceptual documents, strategy papers and development plans, produced as a result of calls for tender, refer to the fact that with the opening of the "Iron Curtain' the political conditions have emerged for St Petersburg to become once again the gateway to and from Europe, and to thereby reassume its 
historical function in the world economy as a bridge between East and West, especially between the economic centres of Northern and Western Europe and Northern and Central Asia. This depends, however, on the 'restructuring of St Petersburg from an overindustrialized city to a multifunctional post-industrial center', which principally involves releasing intellectual capacities from the military-industrial complex so that they can be invested in civilian production or the tertiary sector (Litovka, 1993; Agafonov and Isljajev, 1995).

Many of the first concepts of development of the city were expressions of rather visionary ideas, and depict in essence a catalogue of requirements that are seldom based on concrete and feasible suggestions grounded in scientifically sound economic analysis of the city and its constituent parts. There was, then, an inherent assumption in St Petersburg of the historical continuity of pre-revolutionary development and, accordingly, that the corresponding functions of the city could and should be revitalized. This recollection on the economic traditions of the nineteenth century, when St Petersburg was considered the most important Russian trade and finance centre of European rank, 'led in the first years of reforms, not so much to realistic and balanced strategic development planning, but rather ... [to planning] broadly in line with the visions of the then mayor, Sobtschak, who wanted to establish St Petersburg as an international finance centre' (Rudolph, 2001). Today, the most important financial and stock market centre by far in Russia is Moscow, where 70-80 per cent of all Russian capital is concentrated, and where 27 of the 30 largest Russian banks have their headquarters (Kolossov, Vendina and O'Loughlin, 1998, 2002).

Only after the ratification of the 'Strategic Plan for St Petersburg' in December 1997 were clear, long-term development aims formulated, which were arrived at on the basis of a 'strategic partnership' between the municipal administration, businesses and organizations of civil society, as well the citizens (Strategic Plan, introduction by V. A. Jakovlev, Governor of St Petersburg, 1998). Approval of the document was preceded by analyses of possible positions the city might take up within the world economy as well as within the Russian economy, resulting in a profound socialeconomic analysis of the economic centre of St Petersburg. As a consequence of this St Petersburg was the first city in the Russian Federation to redefine its role within the European and Russian economic area. The Strategic Plan laid down what the principal functions were to be and the strategic directions to be taken, as well as necessary measures to be implemented.

In order to have a real chance of being integrated into the European economy, St Petersburg has to strive for a clearly defined international functional specialization (Strategic Plan, 1998, p. 46). The strategy paper especially stresses the potential 'gateway' functions of the city: the geopolitical situation after the collapse of the Soviet Union as well as the 
efforts at integration within Europe, have strengthened the role of St Petersburg as a 'transport and communications bridge between Russia and the West'. The Strategic Plan formulates the following overriding objective: the development of the city into an 'international multifunctional contact centre for the Baltic Region and the North-West of Russia' (Strategic Plan, 1998, p. 44). The geographical position as well the existing potential of the city fulfil the requirements for the development of such an international meeting place and integrated centre for transport, commerce, tourism, information and culture. Whether this can become reality depends, however, on the creation of the appropriate infrastructural and institutional arrangements, as well as the guaranteeing of attractive and legally certain general conditions.

Within Russia, St Petersburg remains an important industrial centre, which puts the main emphasis in the necessary process of structural change on increasing the number of highly qualified and well-paid jobs, as well as on the intensified development of science-oriented branches of production. However, there has been a shift in priorities. In contrast to Soviet economic policy, where the prime task of the city rested with the development of a strong industrial centre, the role of the city as a hub for trade and commerce is moving into the foreground.

St Petersburg is not just to be an internationally recognized commercial centre, where economic and business relations between Europe and Asia can be conducted but also the centre for import-export operations in the Russian Federation.

Besides the transport industries and the transport infrastructure, there are effective warehousing and trans-shipping facilities as well as modern communication services, which should make St Petersburg one of the largest information and logistics centres in Russia, and an economically attractive European transit node (Strategic Plan, 1998, p. 16).

Furthermore, the Strategic Plan emphasizes the future role of St Petersburg as a centre for knowledge and education, the prominent location for financial services in the Baltic region, and as world city of culture and centre for tourism within Europe.

The strategic plan does not contain any normative prescriptions; it simply provides orientation for long-term development strategies. This is one of the most frequent criticisms of the document. Urgently required concepts for the concrete economic development of the city are still lacking. The deputy leader of the St Petersburg legislative assembly, Sergei Mironov, noted that with the strategy paper, the city's status as the 'scientific-technical centre of the country' and its 'lead in sciencerelated productive activities' are revoked, and its future fate is mapped out as 'the trade centre for the whole country' (Mironov, 2000). On the other hand, there are equally as many supporters of the document who emphasize, above all, 'the clear declaration of the city's liberal values and 
Table 2.2 Factors influencing the development of St Petersburg

\begin{tabular}{ll}
\hline Advantages $(+)$ & Disadvantages $(-)$ \\
\hline $\begin{array}{l}\text { Geographical position (proximity to } \\
\text { West Europe) }\end{array}$ & Unbalanced economic structure \\
$\begin{array}{l}\text { Open to the world, innovative city } \\
\text { Highly specialized, industry, military } \\
\text { goods dominant } \\
\text { City with population of 5,000,000 }\end{array}$ & $\begin{array}{l}\text { Over-large factories } \\
\text { Great scientific potential }\end{array}$ \\
$\begin{array}{l}\text { Large number of highly qualified } \\
\text { specialists }\end{array}$ & Little management know-how \\
$\begin{array}{l}\text { Above average fraction of private } \\
\text { sector in service and business }\end{array}$ & High (hidden) unemployment \\
Low-cost labour force & Unstable state framework \\
Transport hub & Housing shortage \\
Art and cultural centre of world rank & $\begin{array}{l}\text { Deteriorated technical and traffic } \\
\text { infrastructure }\end{array}$ \\
Large recreation potential & High rate of criminality \\
Historical city centre & High cost of living \\
& High ecological pressure \\
\hline
\end{tabular}

its specific character' and consider these to be features that increase the attractiveness of the city (Shicharevitch, 2000).

\section{Prerequisites for the development of St Petersburg}

At present, the situation is marked by completely contradictory processes (Table 2.2): on the one hand, new initiatives and reconstruction in all areas of society and the economy; on the other hand, economic decline and the disintegration of social structures, as well as the instability of state regulatory structures. The prospects for development are examined more closely below.

(1) The city profits primarily from its excellent geographical position relative to Western Europe. It is a port city, and the most westerly large city in Russia. It is located on the external boundary of the European Union - the Russian-Finnish border is about 150 kilometres from St Petersburg.

The favourable geographical position of St Petersburg and the surrounding region has now moved much further to the fore than at the time of its founding. With the collapse of the Soviet Union, the formerly Soviet Baltic ports of Klaipeda, Liepaja, Ventspils, Riga and Tallinn have become 
foreign ports for Russia. As a result, the importance of St Petersburg as Russia's only remaining Baltic port (besides Kaliningrad) is set to increase greatly in the coming years.

The city plays an important role with regard to foreign trade relations with the northern European and the Baltic states. For the Scandinavian countries, St Petersburg is the 'reopened gate to Russia' and of much greater significance than Moscow. Close economic interdependencies are rapidly developing between the city and the states around the Baltic (cf. points 3 and 4 pp. 43-6).

(2) A further advantage of the St Petersburg region in comparison with other Russian cities can be seen not only in its favourable geographical location on the sea but also in its dense transport network (Figure 2.3). The port serves as the centre of the transport node that connects the inland waterways, the railroads, and the road network. This guarantees a rapid goods distribution in the gigantic hinterland. The port also offers a point of entry for the transit of goods to the Ukraine, Belarus and Asia.

On the whole, the transport infrastructure was, however, neglected during the Soviet period, when the main economic priority was extensive

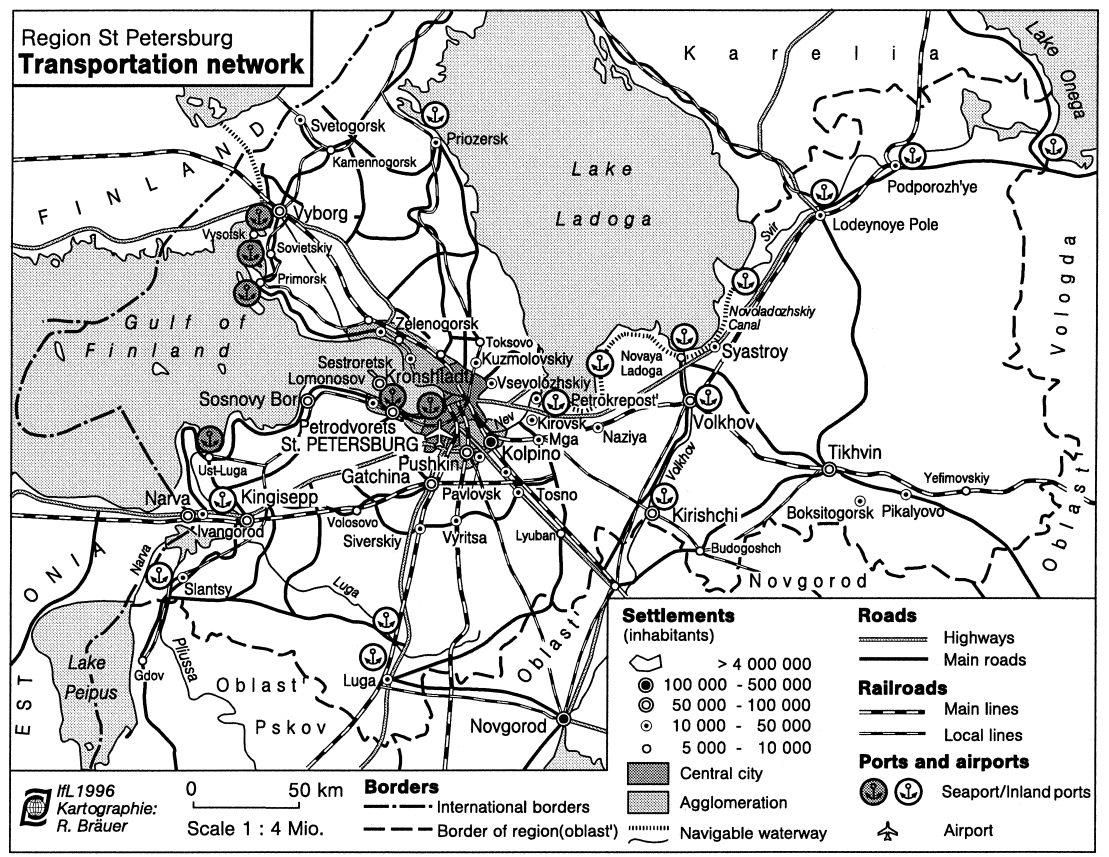

Figure 2.3 Russia's new ports on the Baltic

Source: Based on http://geo.1september.ru/2002/09/4.htm. 
industrialization (Gumpel, 1997). In addition, the spatial reorientation of St Petersburg after the October Revolution meant that investment in the transport infrastructure occurred in accordance with a very different set of priorities. The rather marginal significance - from a Western European point of view - of St Petersburg (and East European centres generally) as a potential European economic centre is largely attributable to the insufficient development of the transport axes that should connect the region to other areas, and to the 'rudimentary state of the trans-regional infrastructure'. To date, this has proved the main technical obstacle to the more rapid development of St Petersburg into a trans-regional transport hub, and 'to more rapid integration of the affected regions into the network Western and Central European metropolitan areas'. At the same time it is also a major reason why investment levels in St Petersburg are not as high as they could be (Rudolph, 1998, p. 13).

In relation to the predicted function as a bridge between the European Union and Russia as well as an important location in the international transit trade, in 1994 a pan-European conference made a declaration listing the most important European transport corridors. One of these was Corridor No. 9: Helsinki - Petersburg - Moscow - Sofia (Strategic Plan, 1998, p. 16). Since then a series of important transport projects have reached the planning and execution phase:

- Rapid Rail Connection Helsinki - St Petersburg;

- Highway Link Helsinki - Wyborg - St Petersburg;

- High Speed Rail Service St Petersburg - Moscow;

- Highway Beltway around St Petersburg;

- expansion of the Pulkovo international airport, including the construction of a trade and business centre.

The significance of St Petersburg as an international transit and transshipment node has already risen since the end of the 1990s. For example, even though the exchange of goods between Finland and Russia has fallen by about a third since the collapse of the Soviet Union, the number of trucks using the border crossings has increased by more than 50 per cent (interviews with the administrative chief of Vyborg rayon, 24 October 1994 and 23 June 1998).

Due to the fact that transport routes through the countries of Eastern Europe are currently still rather unsafe and often involve long waits at border crossings, many countries of western and northern Europe prefer to steer a direct course to the port of St Petersburg or to utilize the land route by way of Finland. In November 1996 a direct ferry service for trucks was established between Mukran on the German island of Rügen and St Petersburg (Verkehrsnachrichten, 1996).

The future significance of St Petersburg as a trade and economic centre will depend to a considerable extent on its function as a port city. The 
volume of goods handled by the port of St Petersburg increased during the second half of the 1990s from 13 million tons (1995) to 30 million tons (2002). The existing capacities of the ports in St Petersburg and Vyborg are no longer sufficient. ${ }^{3}$ To date, the majority of the freight from Russia to Western Europe, the US, Canada and South America is shipped through ports in the Baltic states and Finland, e.g. for Russian container freight the figure is 74 per cent. Likewise, most of the freight flow from Japan and South-East Asia to St Petersburg and Russia comes via these foreign ports (Strategic Plan, 1998, p. 48). One strategic objective for St Petersburg is, therefore, for ports in the St Petersburg region to process at least 90 per cent of the Russian freight that is currently handled by ports in the Baltic states. Another strategic objective is the provision of all the infrastructural and service requirements related to trans-shipping. Some projects (construction of port facilities and pipelines) are already being realized, with the exclusive involvement of large Russian concerns such as Rosugol (coal production), Surgutneftegas, Lukoil, Jukos, Sibneft (petroleum production), and Gasprom (natural gas production). These companies are prepared to contribute most of the funds necessary for the construction of port facilities and pipeline terminals at four locations in the Gulf of Finland, in order to have their own Russian port or terminal (Figure 2.3). ${ }^{4}$

After Moscow, St Petersburg has one of the most extensive railway networks in Russia, but both the tracks and the rolling-stock are hopelessly obsolete and overstretched. Over 90 per cent of the freight locomotives are more than 35 years old. Export and import operations are handled in the ports, while domestic freight is carried on the rails. Over 70 per cent of industrial production in St Petersburg is delivered to other regions of Russia, from where St Petersburg draws over 80 per cent of the raw materials and components it requires (Peterburgkomstat, 2000, p. 66).

(3) In spite of partial insufficient economic and social conditions, and the unsatisfactory political situation, the city harbours a great potential for innovation, if the constant inflow of foreign firms, unbroken since the beginning of the 1990s, continues. This inflow of capital not only provides vital impulses for the economy but also brings much-needed entrepreneurial and managerial know-how to the city, and accelerates the restructuring process and the establishment of the necessary institutions of a market economy. The interest of foreign investors in economic contacts and partnerships with Russian enterprises is concentrated to a high degree in $\mathrm{St}$ Petersburg, as well as the capital, Moscow, and the raw material producing regions, and this tendency is increasing (Table 2.3). In 1993, just 24 German businesses had a presence in the city, but at the beginning of the twenty-first century there are about 150 German firms, among them four banks, various branch offices and active businesses. 


\section{Changes in the functions of St Petersburg}

Table 2.3 Russian regions with the highest foreign investment in 1997 and 2002

\begin{tabular}{lcl}
\hline (A) 1997 & & \\
\hline & $\begin{array}{l}\text { Investments in } \\
\text { 1997, in millions } \\
\text { of US dollars }\end{array}$ & $\begin{array}{l}\text { Share of investments } \\
\text { going to total } \\
\text { investments in Russia, } \\
\%\end{array}$ \\
\hline Moscow & $3,056.4$ & 57.31 \\
St Petersburg & 98.4 & 1.85 \\
Moscow Oblast & 66.1 & 1.24 \\
Sakhalin Oblast & 46.9 & 0.88 \\
Samara Oblast & 62.1 & 1.16 \\
Magadan Oblast & 61.6 & 1.16 \\
Khanty-Mansisk aut. district & 19.2 & 0.36 \\
Arkhangelsk Oblast & 14.6 & 0.27 \\
Krasnoyarsk Krai & 23.1 & 0.43 \\
Tatarstan Republic & 17.1 & 0.32 \\
\hline
\end{tabular}

Source: Ekonomika i zhisn, 11 March 1999.

(B) 2002

\begin{tabular}{lll}
\hline & $\begin{array}{l}\text { Investments in } \\
\text { 2002, in millions } \\
\text { of US dollars }\end{array}$ & $\begin{array}{l}\text { Share of investments } \\
\text { going to total } \\
\text { investments in Russia, } \\
\%\end{array}$ \\
\hline Moscow & 8,441 & 42.7 \\
Omskaya Oblast & 2,402 & 12.2 \\
Sverdlovskaya Oblast & 1,355 & 6.9 \\
St Petersburg & 881 & 4.5 \\
Chelyabinskaya Oblast & 799 & 4.0 \\
Sakhalin Oblast & 707 & 3.6 \\
Tatarstan Republic & 642 & 3.3 \\
Tyumenskyja Oblast & 385 & 1.9 \\
Krasnoyarsk Krai & 364 & 1.8 \\
Samara Oblast & 305 & 1.5 \\
Sacha Republic & 291 & 1.5 \\
Arkhangelsk Oblast & 272 & 1.4 \\
Khanty-Mansisk aut. district & 233 & 1.2 \\
\hline
\end{tabular}

Source: Rossiskiy Statisticheskiy Yezhegodnik, 2003, pp. 605-6.

In September 1993, the German Dresdner Bank and the French Banque Nationale de Paris became the first foreign banks to establish an active presence in St Petersburg. At the end of 2000, more than 1,800 Russianforeign joint ventures were registered in St Petersburg. The majority of these firms are industrial holdings, belong to the business-oriented service sector (consulting, telecommunication) or are engaged in retail and international trade. These companies mainly export non-ferrous metals, commercial timber and lumber, coal, and chemical products (fertilizers). 
Russian-Finnish enterprises are the most numerous of such joint ventures in the city ( 23 per cent of firms), followed by Russian-German (18 per cent) and Russian-US (15 per cent) joint ventures (Peterburgkomstat, 2000, www.rsoft.ru).

St Petersburg's importance in foreign trade has increased greatly. In 2000 the city had the third largest turnover from foreign trade among Russian federal subjects after Moscow and the Tyumen region. ${ }^{5}$

The share of St Petersburg in the total Russian foreign trade turnover has increased every year since 1997, with the exception of the crisis year, 1998. Countries outside the former Soviet Union have become more important as trading partners. ${ }^{6}$ In 2000, 42.9 per cent of trade was conducted with the EU states, 12.3 per cent with the states of Eastern and Central Europe, and just 7.2 per cent with the Commonwealth of Independent States (CIS). St Petersburg's most important foreign trading partner is Germany with 13.4 per cent of trade turnover, followed by the US and Finland each with 9.4 per cent.

(4) While under the new market economy conditions factories and businesses are struggling for markets in which to sell their products, cities are competing with one another to attract investors and create new jobs. During the period of transformation, investment on a large scale is necessary if the economy is to be able to compete within Europe and in the global market place.

The climate for investment in Russia has not been optimal to date, and consequently the willingness to invest, on the part of foreigners and locals, is rather limited. Many foreign firms have only established a branch office, or signed long-term leases on business premises, in order to have an advantageous starting position when the political situation stabilizes and a binding legal framework for economic activity becomes established.

Generally, foreign businesses investing in Russia tend to do so in large centres with a developed market infrastructure, where the people have a relatively high purchasing power, or in natural-resource-rich regions. Although Moscow still remains the centre for domestic and foreign capital investment, St Petersburg counts among the most attractive investment locations to an increasing extent. By the same measure, the monopolistic position of Moscow is weakening with regard to foreign direct investment (Table 2.3). In the last few years, the various regional decision makers have gone to considerable efforts to improve the investment climate in their areas. Table 2.3 shows that St Petersburg has been able to improve its image as an investment location considerably, even though it slipped two ranking places. In a yearly ranking of Russian regions in terms of their investment potential and investment risk, carried out by the business magazine Expert and the Moscow economics institute Expert PA since 1996, St Petersburg consistently occupies one of the top ranks. 
Since 1993 the yearly volume of foreign direct investment (FDI) has increased consistently. In 1993, the total level of FDI was US\$90 million, rising to US\$3.98 billion in $2001 .^{7}$ Investors from 109 countries are active in St Petersburg; of these the most important countries of origin are Germany with 17.1 per cent of investment, the US (15.8 per cent), Cyprus (14.9 per cent $)^{8}$ and the United Kingdom (10.7 per cent) (Peterburgkomstat, 2002).

(5) Integration as a European economic centre has one main requirement, the existence of a developed market infrastructure. The successful establishment of such market economy structures is dependent on institutional restructuring, i.e. the creation of new structures. According to the analysis of the Russian regions referred to above (prerequisites for the development of St Petersburg), the favourable evaluation of St Petersburg's investment potential is due to the comparatively well-developed infrastructure and the existence of market-oriented institutions.

As a location for international trade fairs, there is no alternative to Moscow and St Petersburg in the entire CIS area, according to the Committee of German Business for Exhibitions and Trade Fairs. Apart from these two cities, the only other dedicated centre for conventions and trade fairs that meets the required international standards is in Nizhniy Novgorod. All other trade fair sites in Russia have only a regional character (Ost-West-Contact 1998, p. 10 and 2002, pp. 30-31).

Contrary to the wishes of the city fathers in the early 1990s, St Petersburg has not developed into a financial centre for North-Eastern Europe; nationally, however, it does rank as one of the leading financial centres after Moscow, with respect to the concentration of financial capital and the volume of financial activity. There are now 42 banks in St Petersburg, and 62 branches of banks with headquarters located elsewhere in Russia; of these 51 are Moscow banks. Furthermore, around 100 credit institutions, three stock exchanges and over 100 companies specializing in the trading of stocks and shares operate in the city. An increasing number of Moscow banks are becoming active in St Petersburg.

(6) The great scientific and research potential, with over 100 research institutes, could be counted as one of the strengths of St Petersburg. There are more than 30 institutes of the Academy of Sciences, 42 institutions of higher learning, including the university, with an overall total of 300,000 students. The industrial research institutes, which were established after the Second World War in connection with the promotion of the technology and research intensive industrial sector, should be of particular interest. At the beginning of the 1990s, there were more than 300 such institutes.

The large, centrally led industrial research institutes, sometimes employing more than 1,000 scientists, were dramatically affected by the disintegration of the Soviet Union and the decline in industrial production. 
However, from the large and often desolate research organizations and production enterprises, a multitude of small firms specializing in technology and research and development $(R \& D)$ related services have emerged that are able to react flexibly to national and international markets because of their specialized know-how and positions within well-functioning networks.

In the early 1990s, it was the dominant armaments industry and the related correspondingly well-developed high-tech sector that offered interested foreign firms the chance to establish contacts and partnerships with firms in St Petersburg. Along with the favourable location of St Petersburg due to its harbour and direct proximity to the Finnish border, one factor stressed again and again by high-tech companies - especially from the telecommunications industry - investing in St Petersburg is availability of appropriately skilled personnel coupled with the low wage costs. Besides this, there are special research and teaching facilities for the telecommunications sector, which guarantee a continuous supply of specialists with up-to-date training.

In the city, a market for computer and telecommunications equipment, as well as information services, has developed. There are 2,100 companies engaged in computing and the provision of information and telecommunications services. In 2003 alone, the annual turnover in this sector of the economy rose by 27 per cent.

The concentration of the telecommunications industry in St Petersburg points to the classical locational advantages of the city: the favourable location in international trade and the availability of highly skilled specialists. In May 1998, the subsidiary of an American concern became the fourth company with foreign capital investment, alongside the Russian telecommunications providers, to set up a factory producing telecommunications technology in St Petersburg. These factories are primarily assembly plants, which depend on reliable delivery conditions for continuous yet flexible production (Rudolph, 1999a, p. 5).

(7) As one of the main forces driving structural change in municipal areas, the privatization process has made varying degrees of progress in the Russian regions. The reason for this is that the regulatory measures contained in the privatization policy have been applied in a regionally differentiated manner.

A further advantage of St Petersburg in comparison with other Russian regions is the relatively advanced state of the privatization process. The so-called small privatization, involving the retail trade, service sector, restaurants and small-scale industries, has already been completed.

The city takes a notable place among Russian regions regarding the privatization of former state assets. In 1995, the progress of St Petersburg in achieving privatization was ranked third behind the city of Moscow and the Chelyabinsk region (Urals) (Mögel, 1997, p. 2). At the end of 


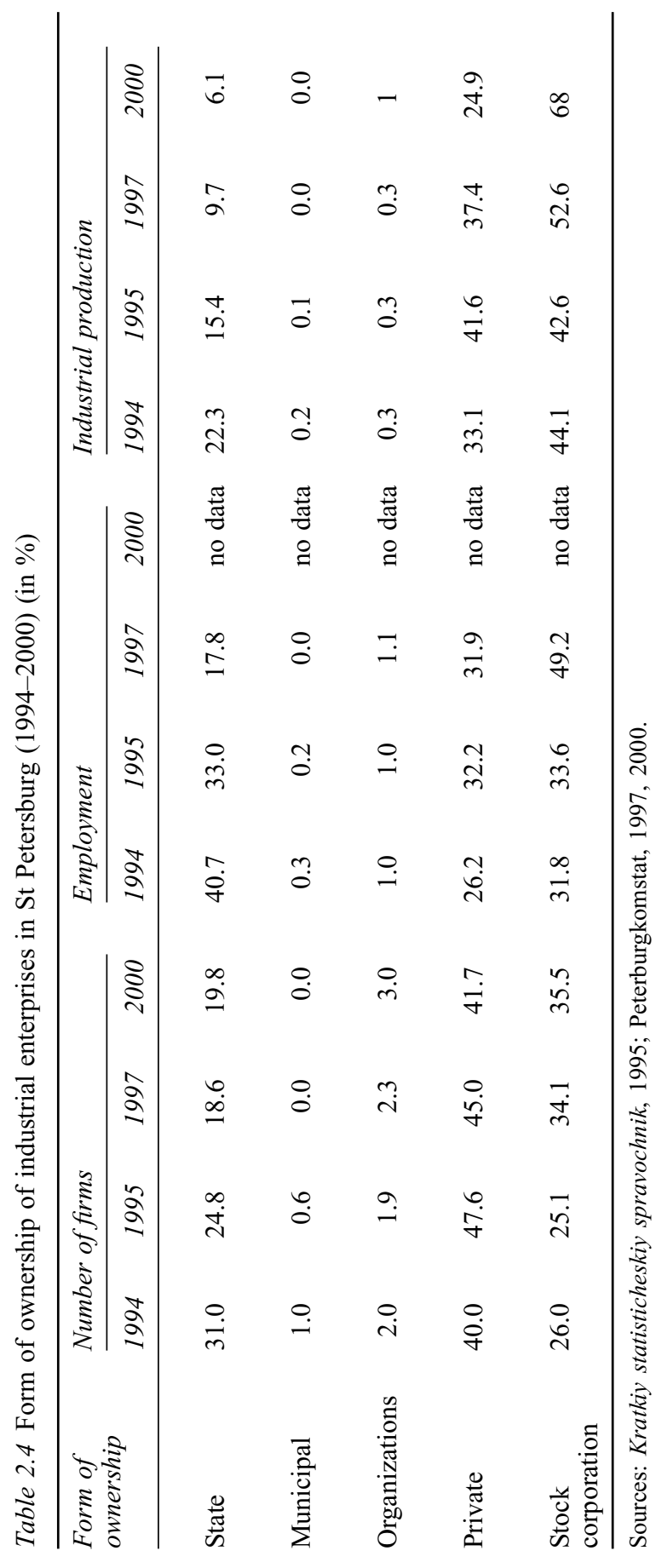


200042 per cent of industrial factories were privately owned, accounting for 24.8 per cent of industrial output. ${ }^{9}$ Mixed forms of ownership involving both state and private capital are, however, of much greater significance in the process of restructuring (Table 2.4). ${ }^{10}$

For the moment, these figures remain largely a statistical accomplishment and cannot hide the fact that this privatization has merely a formal character. Re-registering an enterprise as a private company does not in itself lead to real structural changes being made, particularly when the old management remains in place. Privatization in the first half of the 1990s has led neither to the predicted rise in production nor to the creation of the preconditions for competition and the construction of a market. From the old state monopolists (large combines and industrial units under the direct control of the Union ministries) only privately controlled monopolists (joint stock companies) have emerged, which are governed and operate in a similar manner to their predecessors (Klüter, 1992). Actual competition and innovative rivalry has not, thus far, been observed. To date, the privatization process has not resulted in new capital being investment in the newly privatized enterprises. On the contrary, the situation of these enterprises worsened considerably, since their main capital supplier, the state, simply withdrew from this role during the privatization process. Due to the lack of legal safeguards and unattractive tax laws, a large proportion of any profits made is transferred abroad. Only since the end of the 1990s, the situation in industrial production began to stabilize and first signs of aspirations and even an accelerated growth are emerging.

St Petersburg has been hit especially hard by this. The greatest difficulties at present are tied to overcoming the remaining structural distortions in the economy, and to the privatization of the disproportionately large combines and industrial units that characterized the economy of $\mathrm{St}$ Petersburg as one of the leading centres of mechanical engineering and the armaments industry in the Soviet Union. Changes in the structure of industrial production can be gauged from the changing shares of particular industries in the total volume of industrial output, as well as from the numbers employed in particular industries.

Within the industrial sector, the volume of production in mechanical engineering, which shaped St Petersburg's economic profile during the Soviet period, has declined relative to total industrial output. In 2000, it was replaced for the first time as the leading contributor to industrial output by the food processing industry, which was experiencing aboveaverage growth in the wake of the 1998 financial crisis (Table 2.5). ${ }^{11}$ The collapse of the mechanical engineering industry was even more evident with respect to employment. The large enterprises - which in Soviet times had upward of 10,000 registered employees, mainly those involved in the production of armaments, e.g. the Kirov Works and Electrosila - shed a significant portion of their workforces when they were broken up into smaller units. 
Table 2.5 Development of the structure of industrial production in terms of the total volume of industrial production and total industrial employment (excluding small businesses and joint ventures) (in \%)

\begin{tabular}{|c|c|c|c|c|c|c|c|}
\hline & \multicolumn{3}{|c|}{ Volume of production } & \multicolumn{4}{|c|}{ Employment } \\
\hline & 1991 & 1996 & 2000 & 1991 & 1996 & 2000 & 2001 \\
\hline Industry & 100 & 100 & 100 & 100 & 100 & 100 & 100 \\
\hline \multicolumn{8}{|l|}{ including: } \\
\hline Power engineering & 1.5 & 22.2 & 7.9 & 1.3 & 3.2 & 4 & 9.8 \\
\hline Fuel industry & 0.2 & 0.6 & 0.0 & 0.1 & 0.2 & 0.0 & 0.0 \\
\hline Metallurgy & 2.0 & 4.6 & 4.4 & 1.0 & 2.8 & 2.9 & 5.0 \\
\hline $\begin{array}{l}\text { Chemical and } \\
\text { petroleum } \\
\text { processing } \\
\text { industry }\end{array}$ & 5.2 & 4.1 & 1.4 & 4.0 & 4.1 & 3.1 & 2.3 \\
\hline $\begin{array}{l}\text { Mechanical } \\
\text { engineering }\end{array}$ & 37.6 & 35.4 & 34.0 & 70.5 & 61.9 & 55.7 & 35.7 \\
\hline $\begin{array}{l}\text { Timber, timber- } \\
\text { processing, paper } \\
\text { industry }\end{array}$ & 3.6 & 2.9 & 2.8 & 2.9 & 3.9 & 4.1 & 2.5 \\
\hline $\begin{array}{l}\text { Construction } \\
\text { materials } \\
\text { industry }\end{array}$ & 2.2 & 2.7 & 2.4 & 1.9 & 2.0 & 3.4 & 2.6 \\
\hline Light industry & 17.7 & 2.8 & 2.4 & 9.1 & 8.0 & 6.2 & 2.0 \\
\hline Food industry & 16.7 & 18.0 & 39.0 & 5.2 & 7.8 & 13.1 & 36.3 \\
\hline Other & 13.3 & 6.7 & 5.7 & 4.0 & 6.1 & 7.5 & 3.8 \\
\hline
\end{tabular}

Source: Strategic Plan, 1998, Peterburgkomstat, 2000, Regiony Rossii: socialnoekonomicheskie pokazateli 2002, p. 398 .

The main causes of the rapid decline are: the shattering of the embedded relations based on a spatial division of labour between the Union republics that were inherent to the planned economy; the serious drop in orders; and the dearth of subventions and investment on the part of the state. In the armaments industry alone, orders have dropped by more than twothirds since 1992.

Table 2.6 shows the sources of investment in the city of St Petersburg. The share of investment from the federal and local authority budgets has decreased drastically, while the share of investment by private businesses and organizations has increased almost five times. Investment by private companies and joint ventures has also increased notably, while there are no longer any enterprises in local authority ownership that can point to significant investment activity.

(8) One of the consequences of industrial decline is the loss of a large number of jobs (see Tables 2.5 and 2.7). However, this is not reflected in a high unemployment rate, due to the practice of granting employees 
Table 2.6 Funding of capital investments (in \%)

\begin{tabular}{llll}
\hline & 1995 & 1996 & 2000 \\
\hline Total & 100 & 100 & 100 \\
including: & & & \\
Federal budget & 20.0 & 9.0 & 15.0 \\
Local budget & 22.0 & 13.0 & 22.0 \\
Resources of enterprises & 50.0 & 63.0 & 42.0 \\
$\quad$ and organizations & & & \\
$\quad \begin{array}{l}\text { including: } \\
\quad \text { Municipal property }\end{array}$ & 23.1 & 12.7 & 0.0 \\
$\quad$ Mixed ownership & 22.3 & 30.6 & 19.0 \\
$\quad$ Private property & 4.6 & 19.7 & 23.0 \\
Foreign property and & 8.0 & 15.0 & 21.0 \\
$\quad$ joint ventures & & & \\
\hline
\end{tabular}

Source: Strategic Plan, 1998, Peterburgkomstat, 2000.

long-term, unpaid holiday. The majority of new jobs have been created in the retail and services sectors, which are undergoing dynamic growth. On the whole, St Petersburg, like Moscow, has an attractive labour market. According to official state statistics, unemployment has declined in recent years. In 1998 there were still 40,600 people registered as unemployed, that is, roughly 1.6 per cent of the economically active population in

Table 2.7 Distribution of citizens employed in different industries in St Petersburg

\begin{tabular}{|c|c|c|c|c|c|c|c|}
\hline \multirow{2}{*}{$\begin{array}{l}\text { Branch of the } \\
\text { economy }\end{array}$} & \multicolumn{7}{|c|}{ Percentage of employment } \\
\hline & 1990 & 1992 & 1994 & 1995 & 1996 & 2000 & 2001 \\
\hline $\begin{array}{l}\text { Industry and } \\
\text { construction }\end{array}$ & 44.2 & 43.7 & 39.5 & 36.1 & 35.2 & 30.5 & 31.5 \\
\hline $\begin{array}{l}\text { Communication and } \\
\text { transportation }\end{array}$ & 8.8 & 9.6 & 9.7 & 9.3 & 8.9 & 9.0 & 8.9 \\
\hline Trade and catering & 8.2 & 8.5 & 11.6 & 14.8 & 15.1 & 17.5 & 20.6 \\
\hline $\begin{array}{l}\text { Housing and public } \\
\text { utilities }\end{array}$ & 5.9 & 5.2 & 5.6 & 5.4 & 6.0 & 5.2 & 5.4 \\
\hline Medical care & 6.1 & 6.3 & 6.8 & 6.9 & 6.9 & 7.4 & 6.5 \\
\hline $\begin{array}{l}\text { Education, art and } \\
\text { culture }\end{array}$ & 8.5 & 10.3 & 10.8 & 10.8 & 11.0 & 10.1 & 10.7 \\
\hline $\begin{array}{l}\text { Science and science } \\
\text { services }\end{array}$ & 12.9 & 11.0 & 9.1 & 8.5 & 7.4 & 6.1 & 5.3 \\
\hline Financial sphere & 0.3 & 0.5 & 1.2 & 1.4 & 1.3 & n.d. & n.d. \\
\hline Administration & 2.0 & 2.2 & 2.2 & 2.7 & 2.8 & 4.6 & n.d. \\
\hline Other & 3.1 & 2.7 & 3.5 & 4.2 & 5.4 & 9.6 & 11.1 \\
\hline
\end{tabular}

Sources: Samokhin, Liuhto and Achobadse, 1993; Peterburgkomstat, 1994, 1996, 2000; Strategic Plan, 1998; Regiony Rossii: Socialno-ekonomicheskije pokazateli, 2002, p. 80. 
St Petersburg (St Peterburgskie vedomosti, 2 February 1999); by the end of 2003 this figure had declined to 19,300 ( 0.8 per cent). The rate of joblessness for St Petersburg increases greatly when calculated according to the International Labour Organization (ILO) methodology (4.3 per cent in 2003). However, it is still almost half that of the Russian average (8.3 per cent in 2003).

Besides the armaments industry, the main sectors affected by job losses are science and research. The trans-regional and international effectiveness of these sectors is an important factor in the evaluation of $\mathrm{St}$ Petersburg as a industrial location. But the area of science and research is particularly dependent on state funding. Since the early 1990s a steady stream of scientists in St Petersburg, as in many other cities, has been emigrating or joining the retail and services sectors (Table 2.7).

(9) Key to the development of metropolitan, cross-regional, i.e. transnational, functions is the emergence of a private, business-oriented service sector. The dramatic decline in industrial production, and the introduction of market economy conditions and the accompanying privatization, triggered a boom in the small business sector that was a direct reaction to the crisis- ridden, early years of transformation.

On the fringes between the formal and informal economy an extensive business sector, the so-called maliy biznes (small businesses), rapidly sprang up, spontaneously and unchecked; this reduced the existing underprovision and produced a completely new area of activity, businessoriented services. Numerous private small to medium-sized businesses were founded in the retail and services sectors that had been characterized by under-provision (Table 2.8). Because state regulatory mechanisms and the legal framework, as well as the institutionalization of the market economy, are still insufficiently developed, this process is occurring in a largely deregulated and informal environment. As a result it is difficult to monitor and evaluate the economic activities of these small businesses.

Since the end of the 1990s the share of services in the gross regional product of St Petersburg increased notably and reached 61 per cent in 2002 (in Moscow 82 per cent) (Peterburgkomstat, 2003).

Nearly 100,000 small enterprises were active in the city in 2003, increasing their share of the entire economy of the city to 25 per cent. Most of them were established in trade, transport and communications.

In most industries the demand for premises and floor space has increased tremendously. Supply has in no way kept pace with demand. The demand for appropriate business premises is still nowhere near being met. In 2002, there were around 225,000 square metres of office space that met European standards; this corresponded to just 12 per cent of the office space in Berlin, or 8 per cent of that of Moscow (Nedvizhimost Sankt-Peterburga, 2003, p. 137). ${ }^{12}$ 
Table 2.8 Selected indicators for small businesses according to form of ownership, 2000

\begin{tabular}{|c|c|c|c|c|c|}
\hline & \multirow[b]{2}{*}{$\begin{array}{l}\text { Companies } \\
\text { in total }\end{array}$} & \multicolumn{4}{|c|}{ Companies according to form of ownership } \\
\hline & & Private & $\begin{array}{l}\text { Mixed, } \\
\text { without } \\
\text { foreign } \\
\text { capital }\end{array}$ & $\begin{array}{l}\text { Mixed, } \\
\text { with } \\
\text { foreign } \\
\text { capital }\end{array}$ & $\begin{array}{l}\text { Foreign- } \\
\text { owned }\end{array}$ \\
\hline $\begin{array}{l}\text { Number of } \\
\text { companies ('000s) }\end{array}$ & 109.2 & 102.8 & 3.2 & 1.9 & 1.3 \\
\hline Share of the total $(\%)$ & 100 & 94.2 & 2.9 & 1.7 & 1.2 \\
\hline $\begin{array}{l}\text { Number of employees } \\
\text { ('000s) }\end{array}$ & 627.5 & 591.9 & 18.4 & 10.8 & 6.4 \\
\hline Share of the total $(\%)$ & 100 & 94.4 & 2.9 & 1.7 & 1.0 \\
\hline $\begin{array}{l}\text { Average monthly wage } \\
\text { (Russian roubles) }\end{array}$ & 1,503 & 1,488 & 1,760 & 1,447 & 2,273 \\
\hline $\begin{array}{l}\text { Monthly wage in relation } \\
\text { to the average }(\%)\end{array}$ & 100 & 99.0 & 117.1 & 96.3 & 151.2 \\
\hline $\begin{array}{l}\text { Volume of production } \\
\text { including services } \\
\text { ('000 million } \\
\text { Russian roubles) }\end{array}$ & 48.1 & 44.1 & 2.2 & 1.4 & 0.4 \\
\hline Share of the total $(\%)$ & 100 & 91.5 & 4.6 & 3.0 & 0.9 \\
\hline
\end{tabular}

Source: Peterburgkomstat, 2000: Sankt-Peterburg 2000. Kratki statistitscheski sbornik (Statistical Yearbook). Gosudarstwenny komitet statistiki, S.-Peterburg.

The retail sector in St Petersburg has not yet reached an internationally comparable standard either. The amount of retail space per inhabitant has indeed increased considerably from 0.2 square metres per inhabitant in 1992 to 0.83 square metres per inhabitant in 2003, but this level of provision is still far below the level in Western and Central European cities (e.g. 3.5 square metres per inhabitant in Helsinki). Of the 3.7 million square metres of total retail floor space (including markets and kiosk-like pavilions), only 250,000 square metres are in the more expensive price category (Nedvizhimost Sankt-Peterburga, 2003, p. 145).

The historical downtown of St Petersburg is surrounded by an extensive industrial belt, which was generously laid out in the nineteenth century and which, during the course of Soviet industrialization, came to be occupied by large enterprises that required a lot of space. Most of these enterprises cannot, by reason of their economic situation, take advantage of the opportunity to purchase the land they require and make further investments. These sites represent long-term reserves of space to which potential new uses could be introduced. The sale of these sites at market prices is equally improbable because of the country-wide collapse of industry and investment activities, and the corresponding low demand for such sites. So the 
city remains the owner of the majority of sites in this industrial belt, which are considered to be extremely problematic as far as an integrated development of the city is concerned. On account of general macroeconomic instabilities, as well as their own capital weaknesses, the long term leasing of land (as a rule, 49 years) has proved to be the only possible alternative for large enterprises with extensive or expanding spatial requirements (Rudolph, 1999b, p. 17 f.).

In 2002, no secondary market for land had developed; however, as a result of the strict separation of the ownership of land and the ownership of buildings, a market had formed for user rights to office and industrial space in buildings. ${ }^{13}$ This has turned out to be an entirely advantageous arrangement, and has formed one of the essential prerequisites for the aforementioned boom in the tertiary sector. Since the potential businesses had hardly any capital, this arrangement offered those businesses that needed office space or parts of buildings rather than plots of land the chance to keep their start-up costs in check.

(10) Another factor that plays an increasing role in the evaluation of an economic centre is the range of cultural and leisure-time activities. In this respect, St Petersburg is, in global comparison, thoroughly competitive. According to United Nations' ratings, St Petersburg is the eighth most attractive city in the world (Strategic Plan, 1998, p. 17). The city is a tourism magnet with an interesting, historic old town - with innumerable baroque and classical buildings - that was not ruined by Soviet era building work that tended towards the architecturally uninspiring.

The tourism industry was one of the more dynamic sectors of the economy at the end of 2000. After severe collapse in the early 1990s, the attractiveness of the city means that it is once again receiving growing numbers of visitors. More than 80 professional theatres, 10 large concert halls and more than 220 museums attract over 3 million tourists from all over the world (2002: 3.2 million foreign visitors). ${ }^{14}$

In the tourist-oriented services sector, about 100,000 people are employed. However, the city's potential as a European tourist centre has, to date, in the middle of the first decade of the twenty-first century, only been realized to a negligible extent. The infrastructure, especially in the hotel branch, as well as the entire service sector, lags way behind other European tourist centres. Paris, Vienna and Amsterdam, which receive 2-12 million visitors yearly, have 35 or more hotel beds per 1,000 inhabitants. In St Petersburg, there are presently about 100 facilities of all categories that provide accommodation for visitors, i.e. for every 1,000 residents there are 5 beds. But of these, only 43 are in hotels, which have a total capacity of 14,000 beds for use by tourists; this corresponds to a capacity of 3 hotel beds per 1,000 inhabitants. Equally, a great deal of catching-up has to be done in the areas of public relations, city marketing and so forth (Nedvizhimost St Petersburga, 2003, p. 155; Strategic Plan, 1998, p. 19). 


\section{St Petersburg - a window to Russia?}

Russia's orientation towards democratic and market economy conditions provides the city with the freedom to create its own distinctive image. The most important precondition for this is the restructuring of St Petersburg from an over-industrialized city into a post-industrial, multifunctional economic location.

The endogenous potential of this metropolis offers investors, in comparison with other Russian cities, good conditions for business initiatives. St Petersburg is quite suited to take on national as well as transnational functions. Of course, problems such as the disproportionately structured economy, with oversized factories in the armaments sector and in heavy industry, the undirected cutbacks in the research and science sectors, the worn-out state of the local authority and transport infrastructures, the high ecological burden, etc. should not be overlooked (Brade, 1994a, 1994b, 1998). The potential for development exists without doubt, but if this is to be used to acquire trans-regional and transnational functions, then a number of things are required, the most important being: the stabilization of the basic conditions set by the state; clear and applicable legal guidelines for investment and other economic activity; as well as well-balanced, realistic concepts for both urban development and economic strategy.

The process of functional restructuring in St Petersburg is in full swing. The deindustrialization process, accompanied by positive signs of activity in the high-tech sector, the initial stages of a process institutionalizing a market economy, as well as a booming tertiary sector, offer prospects for St Petersburg becoming an attractive economic location, nationally and internationally.

The process of functional restructuring is accompanied by changes in the spatial structure of the city. The emergence of the retail and services sector, in particular, influences the structural transformation of the city to a considerable extent. 


\section{Transformation, tertiary sector and city space \\ Time-space approach}

\section{Spatial saturation: the mechanism for the adaptation of post- socialist urban space to the challenges of transformation}

The transformation period produced a very specific framework for the emerging market for commercial space in St Petersburg. Outlining this in some detail here will aid our further research discussions.

After the end of the era of complete administrative control over the spatial distribution of retail and services facilities, the situation for this sector of St Petersburg's economy seemed to swing to the opposite extreme. Especially during the early stages of the reforms, there was only a minimum of administrative control over this distribution process. The regulation of land use and related matters was based on the shortterm interests of the administration, and there was minimal public control over administrative decision-making. On the one hand, this situation provided fertile ground for large-scale corruption, and on the other, it turned the regulatory process itself into a quasi-market. This obviously allowed the emerging market for commercial space in St Petersburg to develop in much freer circumstances than is the case in Western cities.

Compared with Western standards, there was a striking lack of shopping and service facilities in the St Petersburg of Soviet times. This provided a specific challenge for the new private commercial entrepreneurs, who came into existence after economic liberalization in 1989. On the one hand, the market was crying out for more services and consumer goods. Yet on the other hand, there was no trading space available. The new businessmen found several ways around this problem. First, thousands of spatially mobile, low-cost, kiosk-type commercial facilities were erected and found their place in the market. Second, space in existing facilities began to be used much more efficiently. Third, space formerly used for other purposes was converted into commercial space for use by the retail trade and services.

A situation developed whereby various markets for locations and commercial real estate in St Petersburg emerged that differed in terms of their mechanisms, prices and rent levels. Officially, two major markets 
offered commercial real estate both for rent and sale: the primary and secondary markets.

Prior to the advent of market reforms, all land and real estate in St Petersburg was nationalized. According to municipal estimates, the total amount of non-residential real estate space in St Petersburg in 1994 equalled about 30 million square metres. Approximately 60 per cent of this was municipal property and was leased or offered for sale by the city's executive authorities. The remaining non-residential space was either owned by the federal government and its ministries (most of this space was occupied by the big industrial enterprises and research institutions) or was in private hands. The share of the latter was constantly growing (Nedvizhimost Peterburga, 1995, p. 20).

The primary market was based on the 'minor' privatization (or denationalization) process, which meant the sale or long-term leasing of commercial real estate to market actors through procedures that allowed the actors to buy or rent the desired space for a price significantly below the level on the secondary market. The first sales under 'minor' privatization in St Petersburg took place in May 1992. The long-term lease contract normally included a preferential 'right to buy' option for the leaseholder at the end of the term or even earlier. The pace of 'minor' privatization in St Petersburg was higher than in any other federal subject. During the first three years, about 3,000 objects were sold or leased with the right to buy. Access to the primary market opportunities inevitably became the subject of corruption. By the autumn of 1994, three or four of the largest realtors had a de facto monopoly on access to the municipal auction sales. Although the obvious inefficiency of such a practice for the city's economy meant that the city authorities tried to put a limit on this, it was long possible to lease commercial space from the government for a price ten times lower than that on the secondary market. For example, the rent charged by the city for 1 square metre of office space at the most prestigious location on the Nevski prospect could be just 0.5 US dollars per year (Realtor, 1995). This system persisted until December 1997, when the city governor issued a new regulation on the rent prices for municipal property. According to the new regulation, prices were to be set very close to those of the secondary market, and procedures for price adjustment via the courts were introduced (Nedvizhimost Peterburga, 2000, p. 44). By that time about 4,500 objects had been successfully tendered for sale (Nedvizhimost Peterburga, 1997, p. 30).

The supply of commercial space to the secondary market was basically threefold. First, there was real estate acquired through the primary market procedures outlined above. Second, the denationalization of the large stateowned enterprises was normally followed by the transfer of the business from federal ownership into private hands. This process was usually referred to as 'big' privatization and can hardly be treated as market oriented (Nikulin, 2002). The last supply source for the secondary market 


\section{Transformation, tertiary sector and city space}

was connected with the efforts of the city government to raise budget revenues from privatization through the use of the secondary market for commercial real estate. It is this secondary real estate market that determined the market value of commercial locations and rent levels. But even here, a uniform price scale did not exist.

If the primary market was very tightly controlled by a few privileged broker companies, the secondary market was accessible without intermediaries by any party. The commission charged by commercial real estate brokers was normally 5-10 per cent of the contract value (or one year's rent), although in some cases the charge was up to 100 per cent of the contract value. Hence, if actors were able to find the desired premises themselves, they could significantly reduce the cost to their businesses.

The range of options on the St Petersburg commercial real estate market was incomparably wider than that in Western cities. Table 3.1 provides a summary of the options available to a market actor seeking office space in St Petersburg in 1994-95. The secondary market definitely prevailed and rapidly influenced the value of business locations.

So, the crucial difference between the framework of the market for commercial space in St Petersburg during the transformation period and that of Western cities is that in Western cities all the space is already occupied and its redistribution occurs on the basis of clear cost-related procedures in accordance with regulations. In St Petersburg the development of retail trade and service businesses started in an almost empty

Table 3.1 Range of options available to a market actor seeking office space in St Petersburg in 1994-95 (example, US\$ per sq m)

\begin{tabular}{|c|c|c|c|c|}
\hline & \multirow[t]{2}{*}{ Primary market } & \multicolumn{3}{|c|}{ Secondary market } \\
\hline & & $\begin{array}{l}\text { From adminis- } \\
\text { tration }\end{array}$ & $\begin{array}{l}\text { Through a } \\
\text { broker }\end{array}$ & $\begin{array}{l}\text { Directly from } \\
\text { owner }\end{array}$ \\
\hline Location & $\begin{array}{l}\text { Limited access } \\
\text { Limited supply } \\
\text { Possible illegal } \\
\text { operations } \\
\text { Uncertain results }\end{array}$ & $\begin{array}{l}\text { Limited supply } \\
\text { Limited owner- } \\
\text { ship rights } \\
\text { Bureaucratic } \\
\text { formalities }\end{array}$ & $\begin{array}{l}\text { Greatest supply } \\
\text { Guarantees } \\
\text { Minimum } \\
\text { formalities }\end{array}$ & $\begin{array}{l}\text { Time-consuming } \\
\text { competition } \\
\text { with other } \\
\text { actors in the } \\
\text { market place, } \\
\text { especially with } \\
\text { broker com- } \\
\text { panies } \\
\text { No guarantees } \\
\text { Uncertain results }\end{array}$ \\
\hline 1 Priority & 100 & 500 & 1,000 & 850 \\
\hline 2 Priority & 50 & 250 & 800 & 600 \\
\hline 3 Priority & 10 & 50 & 300 & 200 \\
\hline
\end{tabular}

Source: Authors' expertise. 
market space; there was only a minimum of administrative regulation, and there was no uniform price system for commercial space that could rule the market as a whole.

The major conclusion that we can draw so far is that during the transformation period St Petersburg's commercial real estate market operated in a situation where there was a much wider range of possible business locations, which meant that the market for commercial space was subject only to a modest set of restraining conditions.

The fundamental economic motor of transformation, to which the retail trade and services sector of the economy in all Russian cities has been

Table 3.2 Branches of the retail trade and services sector in which the number of facilities increased by more than ten times, 1989-96

\begin{tabular}{|c|c|c|c|}
\hline Branch & $\begin{array}{l}\text { No. of } \\
\text { objects, } \\
1996\end{array}$ & $\begin{array}{l}\text { No. of } \\
\text { objects, } \\
1988\end{array}$ & $\begin{array}{l}\text { Change } \\
\text { (no. of } \\
\text { times) }\end{array}$ \\
\hline \multicolumn{4}{|l|}{ Retail trade } \\
\hline Office equipment & 200 & 0 & - \\
\hline Automobile & 194 & 5 & 38.76 \\
\hline Construction goods & 405 & 30 & 13.50 \\
\hline Car parts and accessories & 190 & 15 & 12.67 \\
\hline Furniture & 305 & 25 & 12.20 \\
\hline Audio, video, electronics & 315 & 30 & 10.50 \\
\hline \multicolumn{4}{|l|}{ Service } \\
\hline Tourist companies and travel agents & 600 & 3 & - \\
\hline Auditing, consulting, marketing & 194 & 0 & - \\
\hline Advertising agencies & 180 & 0 & - \\
\hline Banks: affiliates & 170 & 0 & - \\
\hline Brokerage & 120 & 0 & - \\
\hline Design, stylists & 118 & 0 & - \\
\hline Security & 80 & 1 & - \\
\hline Charity & 67 & 0 & - \\
\hline Railway transport & 57 & 1 & - \\
\hline Casinos, night clubs & 55 & 0 & - \\
\hline Computer hardware and software & 490 & 10 & 49.00 \\
\hline Banks: central offices & 130 & 4 & 32.50 \\
\hline Investment and financial services & 289 & 10 & 28.88 \\
\hline Air transport & 51 & 2 & 25.65 \\
\hline Notaries public & 475 & 20 & 23.75 \\
\hline Real estate & 348 & 15 & 23.18 \\
\hline Telecommunications & 215 & 10 & 21.50 \\
\hline Automobile servicing & 295 & 15 & 19.67 \\
\hline Legal services & 304 & 20 & 15.20 \\
\hline Paper supply & 114 & 10 & 11.40 \\
\hline Total for all branches ${ }^{\mathrm{a}}$ & 16,563 & 4,433 & 3.74 \\
\hline
\end{tabular}

Source: Compiled from Axenov, Brade and Bondarchuk, 1997.

Note: a Including branches not outlined in the table. 
exposed during the last 10-12 years, is the saturation of local market demand for consumer goods and services.

The most visible part of the 'demand saturation process' was the increase in the number of retail trade and services facilities throughout St Petersburg, which occurred at a speed and to an extent that had not been experienced for many decades (Table 3.2).

The rapid growth of this sector of the urban economy has been experienced in recent times by most cities in the West as well. The origin of this growth in the West is, however, essentially different from that in Russia. In Western cities it was related to the transition to a post-industrial stage of development. This transition resulted in the shift from 'consumption society', with mass production and mass consumption, to more personalized forms of consumption, with the growth of business service activities and the role of the service sector in the economy in general. So we may say that in most Western cities, rapid growth of the retail trade and services sector marked the transition from the saturated market demand of industrial society to the saturated market demand of post-industrial society.

Contemporary St Petersburg demonstrates certain distinct traces of a shift towards the post-industrial stage - concentration in high-tech branches, rapid growth of the business services sector of the economy, the boom in information technology and telecommunications, for example (see also Taylor and Hoyler, 2000). At the same time, prior to $1988 \mathrm{St}$ Petersburg, like other Russian cities, had never experienced the 'consumption society' stage with saturated market demand. This means that in the last decade of the twentieth century the St Petersburg economy has merged together two processes that in Western cities were separated in time and were organically produced by different stages of economic development. Thus we may suggest that the transformation of the retail trade and services sector in St Petersburg marks the change from the undersaturated market demand of industrial society to the saturated demand of post-industrial society.

After the abrupt opening of St Petersburg to both the international market and to market-driven forces in 1988, it turned out that neither the local economy nor the city's infrastructure were able to respond to local demand for consumer goods and services. A huge amount of imported consumer goods flooded the city, where only about one-tenth of the required trading, storage, transportation and other related facilities existed. The process of spatial adaptation to the increased needs of the retail trade and services market in the city began.

We make the forms and characteristics of this type of spatial adaptation the focus of our attention. We suggest that the adaptation (reorganization) of space in the city in order to saturate local market demand for consumer goods and services under transformation might be called spatial saturation with consumer goods and services. 
Spatial saturation with consumer goods and services is a time-space process. In the process of our research, we have observed what appear to be two different spatial forms of such saturation. In our further discussion we shall treat them separately and in detail. Here, we intend only to define them and outline their major features. The two forms of spatial saturation are different in their origin and the direction of the locational process.

\section{Spatial transformation of vertical business structures}

The most visible structural changes affected the principles of location of specific branches of the retail trade and services and their facilities. Hereafter we shall refer to the structures that bring together primary business units into branches as vertical business structures. The combination of factors affecting the location of an individual facility, company or particular branch of the retail and service sector as a whole has changed dramatically. In Chapter 5, we specify and describe the main mechanisms for this form of spatial saturation, which we call spatial competition within a branch for better location of individual facilities and spatial division of the market among different branches.

The first process is based upon the desire of an entrepreneur to place his or her business in the best possible location, in order to gain an advantage over competitors in the same branch that are not so favourably located.

The spatial division of the market among different branches is caused by two main processes. The first is prescribed by the differences in the locational preferences of different branches, based upon their specific technological and marketing requirements. Automobile servicing or commercial parking requires much more space and seeks a different clientele than, for example, lawyers' offices or boutiques do. Yeates outlines different locational scales at which spatial competition between different branches occurs (Figure 3.1). Obviously, shops and offices from branches that seek a city-wide clientele would normally look for locations in different places and according to different principles than those targeting local consumers.

The second process that contributes heavily to the spatial division of the market is competition among branches for the same types of locations. Some branches have almost the same locational requirements as others, due to a common clientele and similar business facilities parameters. Consulting companies, lawyers, notaries and others basically require a similar type of office space and tend to attract city-wide clientele; thus they tend to seek the same kind of location. Obviously, this form of competition should favour branches with a higher degree of economic efficiency, since they can afford to spend more on office space or other commercial real estate. 


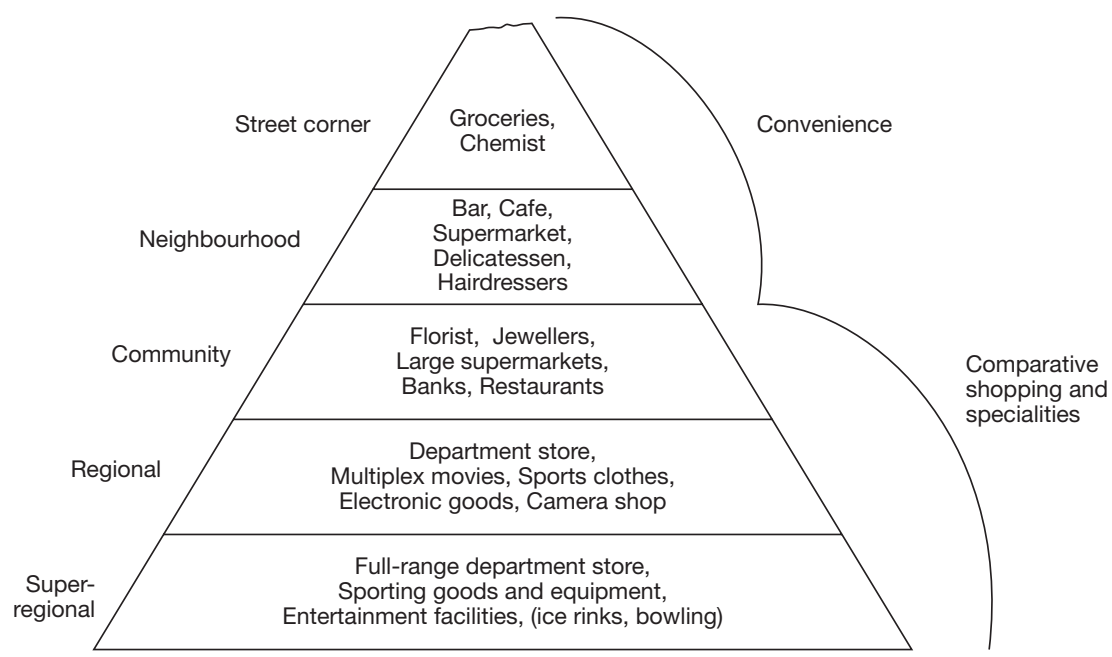

Figure 3.1 Representative example of retail activities that are typical of different levels in the hierarchy of commercial nucleations

Source: Yeates, 1990, p. 245.

Spatial competition within branches for better locations for individual facilities and spatial division of the market between different branches give the locational process a centrifugal or contripetal direction. They compel companies to look for locations that are new and better, or sufficing. In the post-socialist city, which had a very limited set of commercial spaces to offer, they forced businesses to explore new commercial spaces, expanding to cover the whole city. We can state that these forms of spatial saturation give the locational process a 'centrifugal impetus'.

\section{Territorial complex building}

Another form of spatial saturation appears to be 'territorial complex building' or 'clustering'. ${ }^{1}$ This form relates to the geographical factors affecting the horizontal structures of business as a whole. By 'horizontal structures' we mean the territorial systems (or complexes) of individual facilities that originate from the specific features of relevant locations - a certain combination of business structures and city infrastructure. A given space can itself contribute to the creation of certain forms of interdependence between the individual establishments that locate there. The origin of this interdependence does not derive from the interests of an individual establishment, or branch even. Some forms of territorial complexes are well documented in the literature (Yeates, 1990). A farmers' market, where many traders come to sell similar merchandise, represents 
one clear example of this sort of complex. In other circumstances, individuals trading in similar merchandise seek, in accordance with the specific demands of their business, business locations as close to their potential customers and as far from competing traders as possible. In the case of a market place they accept the competition from other traders in the same merchandise, since the existence of a market as a territorial system (complex) attracts additional customers that the individual trader could never reach on his or her own. Competition for locations among individual establishments (traders in this case) occurs on a micro-level within the limits of the respective territorial complex. But more important for all establishments and companies in a complex, is the joint locational advantage that the territorial complex gives its members as opposed to their competitors located outside the complex. The territorial complex, not the individual trader, competes with other traders in the same merchandise outside the complex to attract customers. While in the previous form of spatial saturation locational benefits result from the spatial division of clientele, here additional profits are expected from attracting and sharing the same clientele. Thus, the main direction of the locational process under this form of spatial saturation is 'centripetal'. We study the impact of territorial complex building in Chapter 6 .

\section{Towards post-transformation: factors influencing the location of the tertiary sector in the new urban space}

The location of any business in urban space is regulated by a rather uniform set of factors. In general, they are present in any type of society. Differing socio-economic conditions can only affect the extent to which each of them contribute to the resulting spatial pattern. In general, such factors can be aggregated into two major groups.

The first group of factors represents the locational requirements of the business. These can be produced by or serve the needs of different economic actors. These requirements could reflect the spatial needs of a company or even an individual facility. A big fast food chain such as McDonald's would, when entering a new city, seek to open its restaurant on a large site at a location that can provide not only customers but citywide publicity as well. A small family-owned fast food outlet would tend to look for a location that could provide a number of local daily visitors from nearby offices or transportation nodes. Locational requirements might be generated by the specificity of the business/branch as a whole. These requirements include both market and technological peculiarities that a particular business/branch has to follow in its spatial development. Automobile servicing requires locations with workshop space close to major highways. The central office of a bank would seek a large office space in the most prestigious location and/or in the central business district. 
Quite obviously, the extent and the scale of spatial requirements differ depending on the type of actor involved in the decision-making process.

The second group of factors that regulate patterns of distribution is the set of limitations and regulations that must be obeyed in the location process. Limitations represent 'objectively' existing conditions and possibilities that set the limits of possible choice irrespective of the desires of the actors involved. One set of such limitations is given by the market. Even if a particular market actor decides to influence the general spatial conditions, the result of his or her actions would be inevitably mediated by the changed parameters of the market as a whole. Another major set of limitations can be aggregated under the term conditions of the urban environment. The direction and intensity of the influence of these limiting factors on the spatial distribution of businesses is very varied. This pattern is usually affected by, among others, the following factors:

- land use patterns;

- population distribution;

- $\quad$ spatial economic structures;

- transport and other infrastructural patterns.

The impact of each of these environmental factors is different, depending on the socio-economic conditions. As in the example used with the limitations of the market, if any actor decides to change urban parameters by building a new business centre or even district, only the limits of choice within location decision-making are affected; it does not make all businesses desire to move to the new location.

Unlike limitations, regulations are prescriptive and depend on the decisions of certain actors. For our purposes two types should be outlined. The first is administrative regulation. This implies prescriptions (both written and convention-based), norms and actions produced by the governmental and public authorities at all levels that affect the process of spatial distribution. These include laws, rules, direct prescriptions or other actions by the authorities. The second is informal regulation by non-administrative decision-making agencies. In every society there is a set of conventional norms and relations that influence business decisions and are of nonadministrative origin (Neef and Stanculescu, 2002). To some extent this includes the 'political correctness codex' that can, in some Western countries, form part of the administrative regulations as well. The shadow economy, which exists in every society to varying degrees, is also an example and source of informal regulation. Another is criminal activity, which includes both criminal businesses and criminal forms of regulation, such as racket (as a type of economic blackmail) and other types of pressure.

It was inevitable that transformation should produce a new system of influences that affected the location decisions of the newly emerging 
retailers and service providers. What changes did market reforms bring to the sets of factors outlined above? What factors are of greater importance for the creation of the new spatial pattern of business establishments?

Under the socialist system no final decision on the location of any economic facility could be made without the involvement of the state (federal or local) planning authorities. Their task was to balance the interests of all actors involved in, or associated with, the location decision. Normally, this location was almost fully prescribed. Responsibility for decision-making, which had to occur within state-approved norms, was in the hands of the planning officials. This is no surprise, since the state was the almost exclusive owner of all land and of the whole economy within the Soviet city. ${ }^{2}$ This system involved a rather substantial amount of informal activity. In the highly bureaucratic system of state economic management, 'lobbying' was an informal institution, with each large enterprise having its own 'lobbyists'. Their function was to 'help' bureaucrats make favourable decisions, and to promote the realization of these. Open and, more frequently, hidden bribery, ${ }^{3}$ and 'clan'-type relations were the tools of such 'lobbyists'. The actions of such 'lobbyists' could affect administrative decision-making to some extent. Obviously, no real market

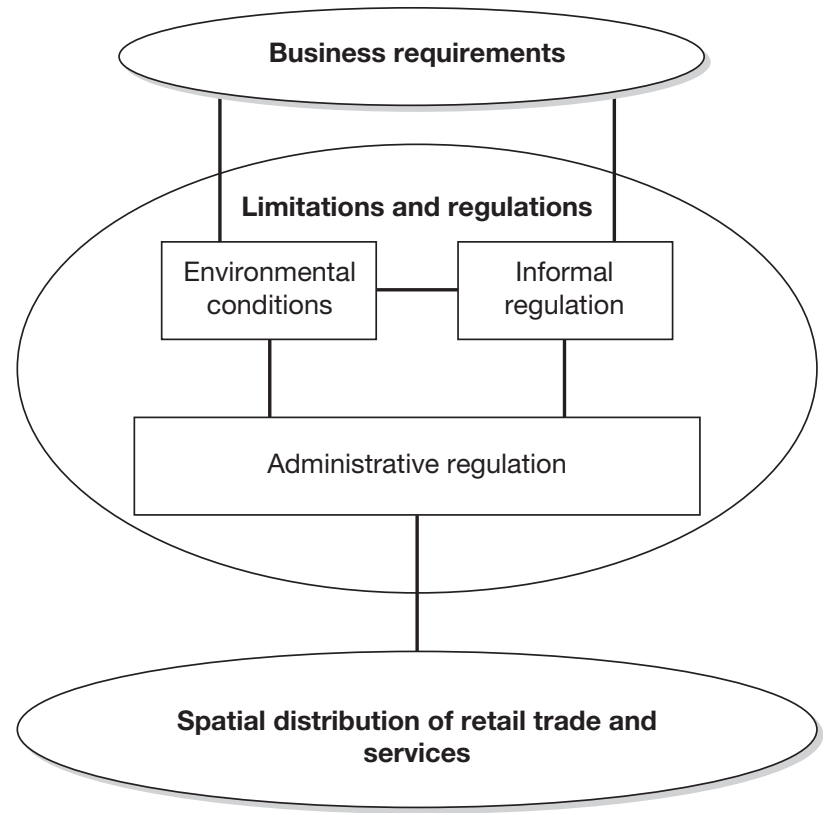

Figure 3.2a Types of factors affecting the spatial distribution of businesses in the retail and services sectors in Leningrad in 1988: socialist period

Source: Authors' expertise. 


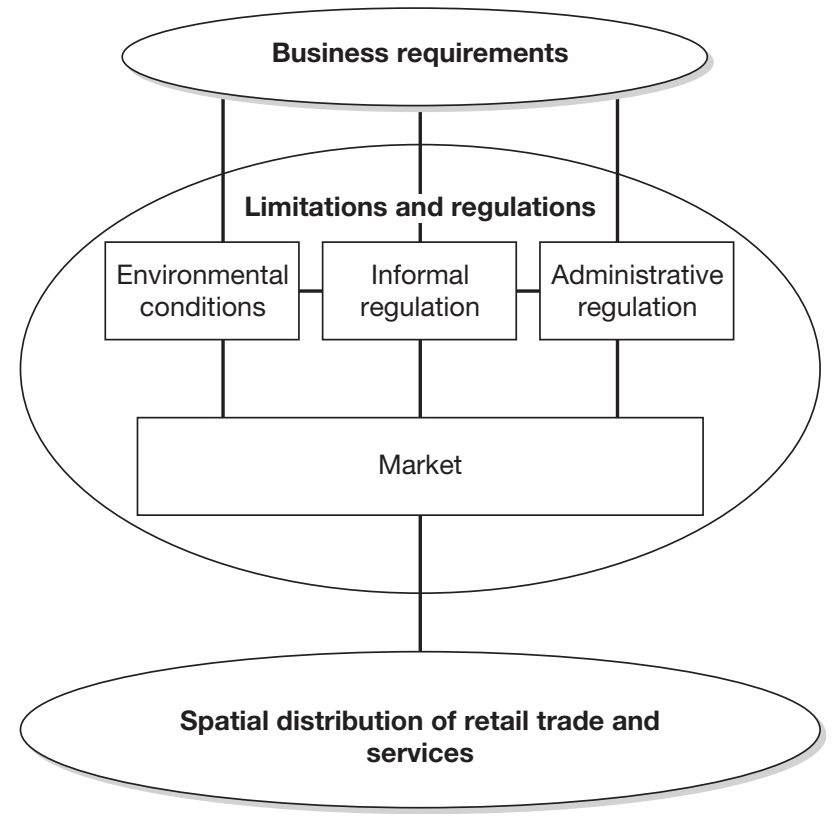

Figure 3.2b Types of factors affecting the spatial distribution of businesses in the retail and services sectors in St Petersburg in 1996: transformation period

Source: Authors' expertise.

existed, so under the socialist economic model the location of economic activity was determined by conditions of the urban environment and the prescriptive decisions of the administrative authorities acting with or without the involvement of informal actors (see Figure 3.2a). The last year that this location decision-making mechanism operated was 1988. Thereafter cooperative and later private economic activity became legal in the city and a new mechanism emerged.

Transformation made real choice, with regard to the spatial location of businesses in the retail trade and services sector, a possibility for all actors involved. The greatest impact upon the location of businesses was made by the introduction of market relations. The role of the state changed; it became protective and regulatory rather than prescriptive. The state inevitably failed to adjust instantaneously all the laws and regulations to the new economic conditions. Some authors describe this situation as a 'systemic vacuum', in reference to the fact that the dissolution of the previous economic control systems occurred, aside from the gradual introduction of a market economy communication system, in the absence of efficient new controls (Dietz, 1992). The state almost lost legal and 
institutional control over the economy: the laws and norms issued sometimes turned out to have absurd consequences and were subject to erratic revisions, and state institutions such as the tax offices, police and courts, etc. were unable to cope with the sheer numbers of emerging economic actors (Neef and Stanculescu, 2002).

This regulatory vacuum had to be filled. Functions previously performed by the state were assumed by a set of informal structures ranging from different types of social and business networks to open bribery and criminal 'protection structures' similar to racket. State-approved laws and norms were replaced by informal rules and 'regimes of cooperation'. ${ }^{4}$ Some authors consider these newly emerged informal regulatory structures to be rooted in the informal networks and institutions of the socialist period (Grabher and Stark, 1998). The role of informal regulations sometimes became so pronounced that the division of branches of business and urban space between criminal groups was discussed in the mass media, as well as by the general public and businessmen in interviews we conducted in 1994. Informal structures did not completely replace the state in the regulatory process, although they obviously competed with it for the economic control. Very importantly, neither state nor informal structures could any longer totally prescribe the location decisions of economic actors. They only contributed to the choice parameters offered by the emerging market. Public authorities have to be treated as just one of the forces conditioning the emergence under transformation of a market for commercial space in the city (Figure $3.2 \mathrm{~b}$ ).

We can state that under transformation the urban environmental conditions gained significantly in importance, and became the major group of factors shaping the market for commercial space in the retail trade and services sector. One of the main challenges for us is to study the channels of this influence. Each of the urban functions in this group that affected the spatial distribution process under transformation had its own pattern of influence. The combination and overlap of these patterns leads to the resulting general model. In Chapter 5 we describe the different directions of influence of various urban environmental factors.

The shift towards post-transformation in St Petersburg introduced remarkable changes in the combination of factors that we describe. One of the major changes relates to the new role of administrative regulation. The market no longer exclusively shapes the spatial pattern of retail trade and services. State and public agencies have managed to reassert control over the process of business location in the city, although the manner of this control differs from that of the socialist era. The first step towards this was the introduction of uniform market-oriented norms and rules according to which business location should take place. Although the elaboration of this set of rules is far from complete, ${ }^{5}$ this stage of development differs from the transformation period in two respects. First, laws and norms are no longer subject to abrupt and radical change. Second, 
Since 1996-97 the St Petersburg authorities have been intervening quite actively in the distribution of retail trade and services, initially by issuing regulations on the location and spatial organization of mobile and small trading forms. In 2002, the Administration of St Petersburg adopted the 'Programme addressing the location of consumer market objects in St Petersburg until 2004'. This programme offered investors 132 land plots where retail facilities with prescribed specialization could be built. It was based on the evaluation of the city-wide pattern of distribution for different branches of the retail trade. The declared aim of the authors was to alter the pattern and density of retail trade facilities, in order to optimize the accessibility of different trade forms and branches for consumers (Delovoy Peterburg, 26 February 2002). After this, the city administration worked out the 'Regional programme for the development of the wholesale market infrastructure until 2010' (Delovoy Peterburg, 14 March 2002).

In contrast to the mid-1990s, the enactment of laws by the city today is an open, transparent procedure, where public influence is possible via city deputies, the press, public discussions and other actions. ${ }^{6}$ The adoption of the Land Codex by the Federal Council (Russian parliament) in 2001 marks a very important achievement. This document sets out the main principles and rules for the elaboration of laws on the private ownership of land. In 1993, the new Constitution of the Russian Federation, which included the right to own land, was adopted by referendum; however, some political parties opposed the adoption of the corresponding laws by the State Duma (lower chamber of the Russian parliament); hence the implementation of the constitutional norm was, in fact, blocked. The adoption of the Land Codex was followed by the elaboration of major laws on the private ownership of land, such as the 'law on the circulation of non-agricultural land'. This law, in particular, outlines the parameters of private and other forms of land ownership in big cities such as St Petersburg.

laws and norms are market-oriented, clear to all economic actors, and predictable. This predictability was promoted by the adoption in 1997 of the Strategic Plan for St Petersburg, which outlined the priorities for the city's future development (Strategic Plan, 1998). ${ }^{7}$

Administrative institutions and procedures have also changed to such an extent that the city administration can regulate the market-driven business location process. This control is not fully prescriptive as in socialist times, and is aimed at regulating market relations and urban development 
under new conditions. In 1997, St Petersburg became the first large Russian city to introduce a centralized system for registering property rights; initially residential and commercial properties were registered separately, but since 2001 a single register has been introduced. This action alone has significantly reduced the potential for illegal activity with real estate, and has unified the procedures for the implementation of laws. This centralized property rights register is the only agency that can certify the legality of real estate transactions. The only prescriptive action open to this agency is the refusal to issue such a certificate, but this would be subject to legal proceedings.

The City of St Petersburg is the biggest real estate owner in the city. Via the City Administration's Committee for the Management of City Property, it leases more than 4 million square metres of non-residential real estate. As of 1 January 2002, it had concluded about 20,000 leases on non-residential real estate. The city put on the market a large portion of the 1 million square metres of non-residential real estate that currently belongs to the state unitary companies (Delovoy Peterburg, 5 March 2002). There is no doubt that the city, as the major actor on the commercial real estate market, can exert a considerable influence.

The city administration has not only registered and licensed all legal operators in the St Petersburg trade and services market but has also launched a programme to certify the compliance of retailers and service providers with state-approved sanitary, fire and consumer protection standards ${ }^{8}$ and other norms. As of 1 January 2002, they had certified about 3,700 restaurants and other prepared food facilities $(90$ per cent of the total number), 4,400 retailers (53 per cent), 356 barber shops (47 per cent), 52 dry cleaners (96 per cent) and 241 maintenance and repair companies. For some this certification is voluntary, and for some - such as small retail traders (of the kiosk type) since 2002 - obligatory. (Delovoy Peterburg, 14 March 2002).

Although the city's new General Plan has not been adopted, the city prescribes certain types of land use over large tracts. This is the major direct regulatory mechanism applied to the market. The primary real estate market no longer represents a different set of business possibilities from the rest of the market - municipal real estate auction sales or investment projects tenders are based on the market prices. In contrast to the mid$1990 \mathrm{~s}$, the procedures governing actors in the real estate market have become transparent and uniform. ${ }^{9}$ Legislation stipulates that none of the real estate owned by the city can be leased or sold without having been 


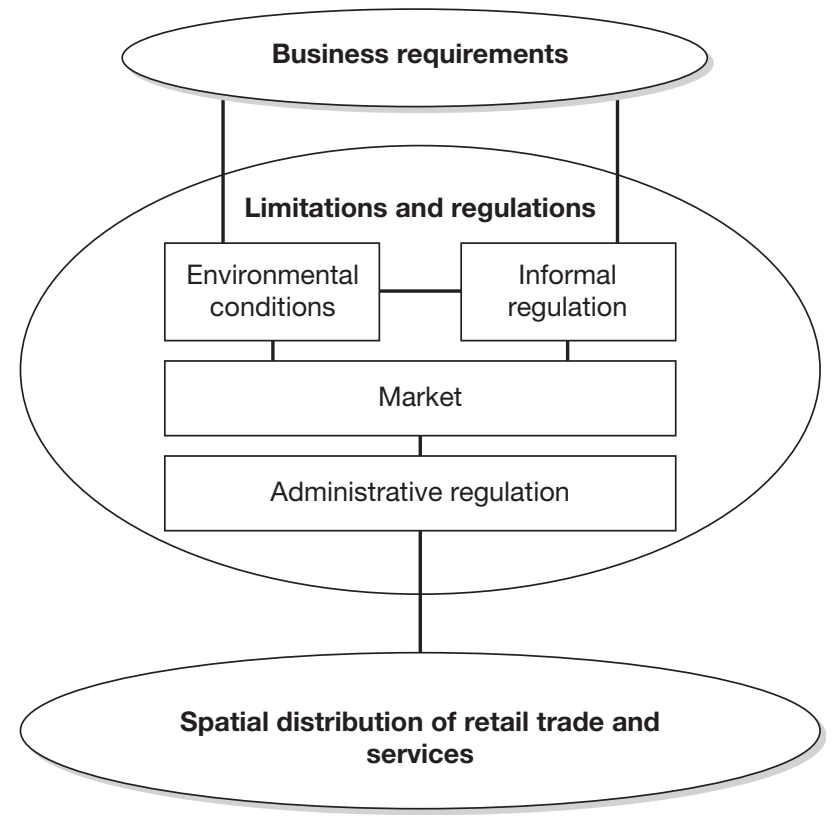

Figure 3.2c Types of factors affecting the spatial distribution of businesses in the retail and services sectors in St Petersburg in 2001: post-transformation period

Source: Authors' expertise.

first listed in an official announcement in the press. Special relations with decision-making administrators can no longer be used to gain privileged access to investment auctions without the threat of prosecution for the actors involved. The judicial system is now in a position to convict top city administrators, politicians and businessmen, which could hardly be said of the early 1990s. ${ }^{10}$ All of these have led to radical reduction in the role of illegal regulation in the city economy, and business location in particular. Emerging small businesses no longer have to look to criminal 'protection structures' to secure their existence. State legal structures have become much more efficient, and new laws and procedures mean that business itself is no longer forced to operate in the shadow.

In summary then, the following features distinguish the posttransformational system of factors affecting the spatial distribution of business in St Petersburg from the previous transformational one: first, the location of business is no longer directly regulated by the market alone; second, the city administration has obtained the role of market regulator in the location process; third, the role of informal regulation has dropped substantially (Fig. 3.2c). 
If we examine the structure depicted in Figure 3.2c, we can find little difference from the system of factors that affect the location of businesses in the retail and services sectors in Western cities. Differences might arise if we compare the relative significance of each factor involved, or measure the degree of completion of the system, but not in the factors involved or their structural arrangement. This fact should contribute to our arguments that the post-transformation stage has been achieved in St Petersburg. 


\section{Transformation and specific forms of spatial saturation ${ }^{1}$}

Transformation as a development stage in the conversion of socialist urban space into Westernized urban space inevitably produced certain specific spatial and business forms and phenomena that could not be attributed to a city that had not experienced transformation. These specific forms emerged and developed alongside conventional trade forms, producing a certain spatial system at certain given times. At different stages of transformation these specific forms played a different role both in the retail trade economy and in its spatial structure. For each stage of transformation we can define trade forms that could be called typical or even essential. Each of these forms produced a spatial system of its own that lent specificity to the spatial system of the retail sector as a whole. We consider the study of these specific transformation forms, their spatial structures, as well as their influence upon the market and the spatial organization of the retail sector as a whole, to be of the utmost importance. ${ }^{2}$ The most challenging objective would be to find out whether these specific transformation forms are responsible for any features of the post-transformational market and urban space that could differentiate the post-transformation city from others.

In this chapter we sketch the development of specific transformation trade forms in St Petersburg during the last 12 years. The major focus will be on the dynamics of the process, from the theoretical perspective outlined above. The key questions that arise here are as follows. Are these specific trade forms an attribute of the transformation stage only? Since these phenomena are an essential attribute of urban space during transformation, they might have produced a specific economic and spatial framework for the introduction of conventional international business forms. What effects have they had on the city's present spatial structure? In an attempt to address these questions, we reproduce some of the findings from our previous studies, which we consider essential to further discussions, describe the most recent developments based on our latest research, and present some new insights into the phenomenon being described. 


\section{Terms and definitions}

Since we are dealing here with the specific trade forms and their characteristics that are unique attributes of a transformation city, it is first necessary to define and describe them. Though some of the terms we use are quite common, we need to ensure that we attribute them to the same phenomena as our readers. In 2000, Russia approved the State Standard 'Trade: Terms and Definitions', which for the first time after socialism defined major terms used in trade (Russian State Standard: GOST P 51303-99). It put an end to multiple variations of terms to describe a single object. This problem was, however, by no means simply a linguistic issue, because the absence of a uniform system of terms provided entrepreneurs with numerous possibilities to evade norms and regulations. We generally follow the terminology offered in the aforementioned document, while adapting them to our research goals and giving our own descriptions. ${ }^{3}$ What are these terms and what do they mean?

- Mobile (trade) forms: trade carried out via auto-shops (a car/lorry containing a kiosk), carriages, counters, other movable appliances or without these mentioned appliances - by individual traders having direct contact with buyers. This is a general term that covers various trade forms ranging from the numerous individual traders selling their merchandise from their hands or improvised counters such as boxes, etc. to those operating from tents and automobiles.

- Fixed (space) stores/facilities: retail trade and services facilities located in specialized buildings/constructions (or parts thereof) that are immobile, fixed to the ground and connected to engineered infrastructure. These include all regular stores and other immobile trading establishments.

- Pavilion: equipped trading construction that has a trading hall and a separate room for a storage. It provides one or more trading spaces.

- Kiosk: equipped trading construction that has no trading hall and no separate room for a storage. It provides one trading space combined with merchandise storage.

- Tent/shelter: easily erected construction with a counter and that has no trading hall and no separate room for storage. It provides one or more trading spaces combined with merchandise storage for one day only. These tents are normally erected in the morning and removed in the evening.

- Small retail (trade): retail trade via pavilions, kiosks and tents as well as via mobile forms.

- Market (place): more or less delimited territory where one company/ organization provides possibilities for small retail trade. Markets can be in the open air or located inside immobile constructions. An open air market normally does not have permanent walls, although light 
structures may offer some shelter. It might provide counters, tents or just space to erect a kiosk, tent, container or other mobile trading form. This type of market ranges from small grounds hosting a dozen or so traders to large, well-managed and secured trading grounds hosting hundreds, if not thousands, of traders. Immobile indoor markets are located entirely or mostly within permanent constructions. The main differences between all markets and the trading complex is that in the former, first, traders do not require a special trading permit from the administration and, second, traders operate on the basis of prices negotiated with the buyer. Markets can specialize in one type of good (like the former 'kolkhoz' farmers' markets, which fit into this group too) or offer a universal spectrum of merchandise.

- Trade complex: permanent sheltered (immobile) construction, in which an operator (or sometimes operators) leases trading space (of comparable size to kiosks) to a number of traders. The main difference from department stores lies in the much smaller size of the trading space available for rent, the absence of a distinct marketing and managerial strategy, the poor appearance and the much smaller range of services provided for traders. The main goal of such complexes, as with markets, is to get the maximum number of small traders to rent space there with minimum investment in real estate and minimum running costs. Unlike in the markets, traders here need a trading permit and operate using fixed (declared) prices.

- Trade zone: territory where small retail trade is possible. It is normally (but not necessarily) supervised/operated by one or several agents and does not have strict territorial limits or any construction on it, and might not be linked to any engineered infrastructure. Officially, traders there require trading permits, but often violate this rule. Traders use their own trading equipment. This form varies from unofficial individual traders operating on a street corner under the supervision of informal managing agents to large official trading grounds such as 'kiosk agglomerations'. This form differs from the market (place) in that traders must have a permit, and normally rent the trading space directly from the city, and in that there is an absence of strict territorial limits and of any additional services for the traders.

\section{Administrative regulation and the stages of development of specific transformation trade forms}

The development of specific transformation trade forms passed through several stages that were heavily dependent upon administrative regulation (Kostinskiy, 2001; Nikulin, 2002). It would be too simplistic, though, to attribute all the changes in the retail and services sector to the implementation of administrative policy alone. As we demonstrate, administrative policy towards the transformation trade forms was successful only when 
it did not violate the major market trends - in terms of the expectations and desires of both consumers and businesspeople. So these periods should be treated as general business development stages, influenced by public policy implementation.

We can outline at least four stages in the development of specific trade forms between 1989 and 2002, which we have termed:

1 the early transformation stage, 1989-96;

2 first stage of administrative restructuring, 1996-98;

3 pavilions and markets stage, 1998-2001;

4 second stage of administrative restructuring and development of larger permanent forms, 2001-02.

How do these stages differ and what impact have they had on the phenomenon of spatial saturation? For each stage we discuss the characteristic trade forms, and the administrative regulations applied, as well as the development of specific spatial structures.

\section{The early transformation stage, 1989-96}

This stage started with the opening-up of Russia to both private economic initiative and to the international market. This gave rise to numerous mobile trade forms and kiosks that became spatially clustered into trade zones (Riley and Niznik, 1994) (Figure 4.1). Declining socialist era public buildings such as stadiums, cinemas, concert and exhibition halls, etc. started to host temporary markets, which were swept away on the rare occasions that the venue was used for its designated purpose.

The kiosks and mobile trading forms have been subject of our research for many years now because we consider them to be the most specific form of the spatial adaptation of post-socialist urban space to the new socio-economic reality. Some results of this research have been published previously (Axenov, Brade and Papadopoulos, 1996 and 1997; Papadopoulos and Axenov, 2002). Kiosks and mobile trading forms have not only made a huge contribution to the transformation process itself but have affected the formation of the new post-transformation spatial structure as well.

Here, we address this topic from several perspectives. We treat the phenomenon of kiosk and mobile trade forms as crucial to the economic, social and spatial adaptation of the city to the challenges of transformation. The kiosks and mobile trading forms became the main tool for the exploration of urban space by the retail trade and services during the first phase of transformation. For at least six or seven years, they represented one of the major mechanisms for the saturation of urban space with consumer goods and services. As the dominant trading form in the city for such a long period, it had several effects that remain evident in the 


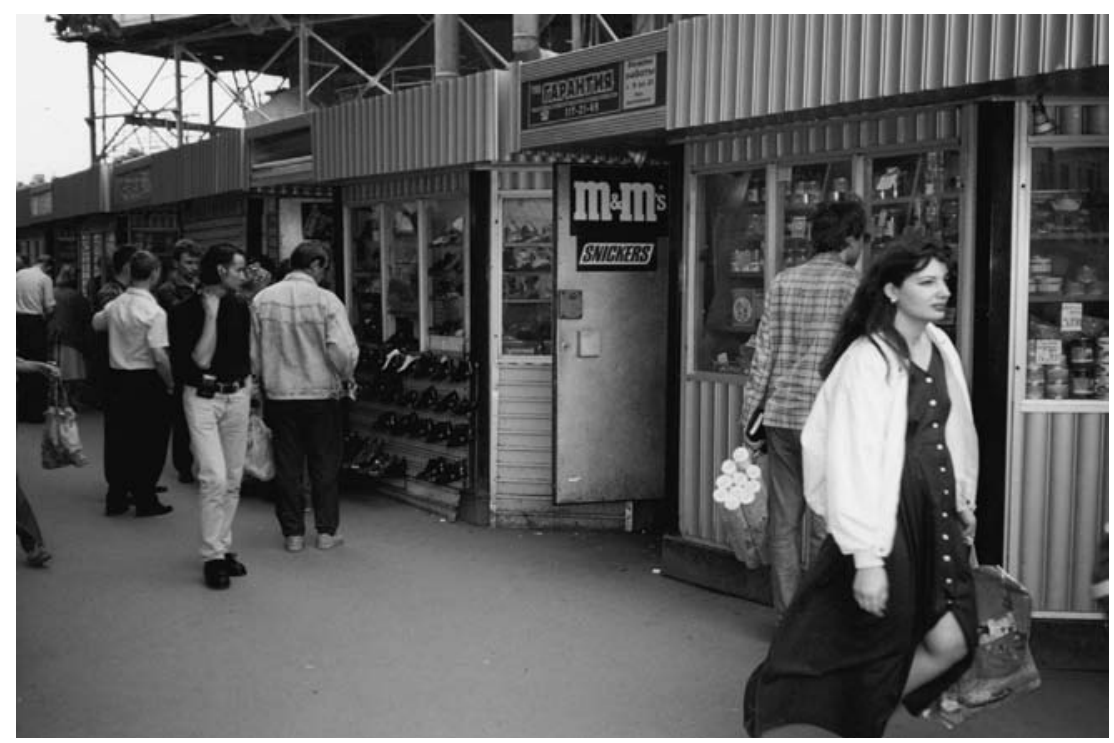

Figure 4.1 Typical kiosk agglomeration, 1995

Source: Photo by K. Axenov.

present post-transformation stage of business development. First, kiosks and mobile trade forms were the first to explore and introduce the market to a new system of commercial space that is of no less value to the contemporary market. Second, they influenced the character of the trading forms that emerged later to replace them. Third, they led to the emergence of shopping practices that have become accepted by the majority of the population and have, as a result, affected location decision-making, in terms of the demands and expectations to be met by a retail location. Fourth, entrepreneurs who started out in kiosks and mobile forms have graduated to become the larger operators and real estate owners in the city's retail trade and services sector. These entrepreneurs now constitute probably the major share of local retail capital in the market. These operators heavily frame the St Petersburg market and are poised to become the major competitors for incoming Western retailers.

Certain conditions gave rise to the phenomenon of kiosks and mobile forms in St Petersburg during the first years of transformation.

\section{Lack of trading space per capita}

Seventy years of central economic planning did away both with private entrepreneurship and the space in which it was conducted. In St Petersburg, there was just 152 square metres of trading space per 1,000 inhabitants in 
1994. For the purposes of comparison, the current German ratio is approximately 1 square metre of trading space per 1,000 inhabitants. The lack of commercial space was especially acute in more recently built dormitory neighbourhoods in the outer zones ringing St Petersburg. This lack of competition and the gradual deterioration of the state's ability to provide more than the basics in the last decades of the Soviet era resulted in an ever increasing gap between supply and demand for consumer goods and decreasing amounts of new commercial space per annum. Kiosks and other types of low-cost mobile commercial establishments satisfied to a significant degree the demand for consumer goods and easily accessible shopping opportunities. By 1996 there were 8-9 fixed space shops and 26-29 kiosks per 10,000 inhabitants in residential areas built under socialism. Even in central city districts these figures constituted 24 and 47 respectively (Sankt-Peterburgskie Vedomosti, 9 October 1996).

\section{Regulation and public attitudes}

Kiosks came into being only when authorities decided to tolerate them. They could be easily removed on the order of the authorities. The informal and flexible character of the kiosks may reflect the public's basic distrust of the state authorities, the police apparatus and the legal system.

\section{Absence of real private property}

A basic precondition for significant investment in conventional fixed commercial space is the unconditional recognition by the state of an individual's right to own property. Although private property was recognized in the 1993 Constitution of the Russian Federation as having an equal standing in law with all other forms of property, significant barriers and disincentives to owning and investing in real estate existed. This inevitably favoured the development of the mobile trade forms.

\section{Transport and shopping}

Data from St Petersburg's 'Institute of the General Plan' on passenger levels for the city's public transportation system reveal that on the average weekday in 1989, 2.7 million metro journeys and 8.2 million journeys on other means of public transport were made. Statistics from 1994 reveal that more than 3 million journeys were registered by the metro management daily. Furthermore, no less than 80 per cent of the city's 5 million inhabitants exclusively used a combination of public transport (metro, buses, trolley buses, trams and trains) and walking to go about their daily business. This was the result of very low automobile ownership rates (see French, 1995). In 1993, there were 91 private cars per 1,000 inhabitants 
in St Petersburg. These transportation facts have significant implications for the structure of commercial space in St Petersburg:

a St Petersburgers employed outside the home expended significant amounts of time in transit between home, the workplace, and various locations that represented shopping opportunities. On an average day, residents could spend three to four hours in transit. Seeking to minimize their time in transit, commuters favoured shopping opportunities close to metro, tram and bus termini and stations, and avoided offroute shopping opportunities. It was calculated that, in the USSR in socialist times, shopping simply for food took the average family 7.6 hours a week, adding up nationally to 35,000 million man-hours a year (French, 1995 after Nikolskiy, 1982).

b Few people could travel by automobile to big supermarkets as in the West. Not only were automobile ownership rates low, but prices in supermarkets were higher than anywhere else in the city. At the same time, shops other than big supermarkets and malls were less likely to offer abundant and reliable food supplies. Consequently, the rationing of time in transit favoured significantly the kiosks that tended to locate close to public transportation nodes. Large agglomerations of kiosks in the immediate vicinity of key metro stations served as open-air multi-stall supermarkets.

\section{Flexibility in marketing}

Kiosks are more flexible marketing platforms. Since they typically do not draw on stockpiled goods, traders can adjust the range and type of their merchandise to the changing demands of the consumers. Experimentation with new products is usually less costly because stocks are limited. With rising competition among wholesale suppliers, kiosk owners increasingly have more sources and variety of commodities to choose from. Only the size of the merchandise and state regulations limit the types of products that can be sold through kiosks.

\section{Locational flexibility}

Theoretically kiosks can be easily moved from one location to another. Although this locational flexibility at first appears paramount to their character, kiosks usually remain on a profitable location for the long term. The cost of constructing a kiosk increasingly became a smaller component of the total cost of investment as kiosks became more and more standardized. In general, kiosks managed to sell products at lower prices than supermarkets because they usually paid low rent, were taxed at low rates, were subject to fewer state controls and had lower maintenance costs, despite 'protection' expenditures. At some point it became common 
for those who could afford it to rent a kiosk at the location of their preference; this meant they could move from one location to another without the burden of owning and having to move the kiosk itself. The market for kiosks and kiosk locations slowly assumed the character of a mature fixed-space real estate market.

\section{Seed capital}

There was tremendous scarcity of venture capital in post-Soviet Russia. The Soviet population held savings in a currency that was not internationally convertible. The first currency reform, albeit necessary, meant the deepening of the investment crisis. Most foreign firms deferred investing in Russia until the political and legal structures would offer firmer guarantees against nationalization. The capital had to be generated by the Russians themselves. The kiosk medium was as important in providing commercial outlets to entrepreneurs and consumers alike as in producing wealth, and by implication, capital for investment.

Two of the factors described above appear crucial for the existence of the kiosk phenomenon - the link between transport and shopping practices, and state regulation. The crucial importance of the link between transport and shopping practices lies in the fact that kiosks constitute a model of shopping that is fundamentally different to shopping in standard retail facilities. When shopping at a fixed-space store the consumer has already had to undertake at least four additional actions. These are:

1 making a preliminary decision that he/she wants to buy a certain item;

2 studying marketing materials;

3 choosing the place where the purchase is to be made;

4 travelling to the trader.

In the case of the kiosk model the consumer is relieved of these actions by the kiosk trader. It is this necessity to bring the merchandise as close to the potential consumer as possible that makes the locational factor extremely crucial.

According to our estimates, based on the results of field studies, in 1994 there were no fewer than 8,000-10,000 kiosks operating in St Petersburg. If one were to count other mobile traders, the number would be several times higher. In contrast, there were only 2,815 officially registered fixedspace stores. By 1997, there was an estimated 30,000 kiosks and mobile traders and about 8,000 fixed facilities (Sankt-Peterburgskie Vedomosti, 1 April 1997). It is hard to overestimate the importance of kiosks and mobile forms for retailing in the city. By 1997, half of all purchases in St Petersburg were made there (Figure 4.2).

For a long time the city authorities failed to regulate (or even simply register) street traders and kiosks on a city-wide basis. Our interviews with 


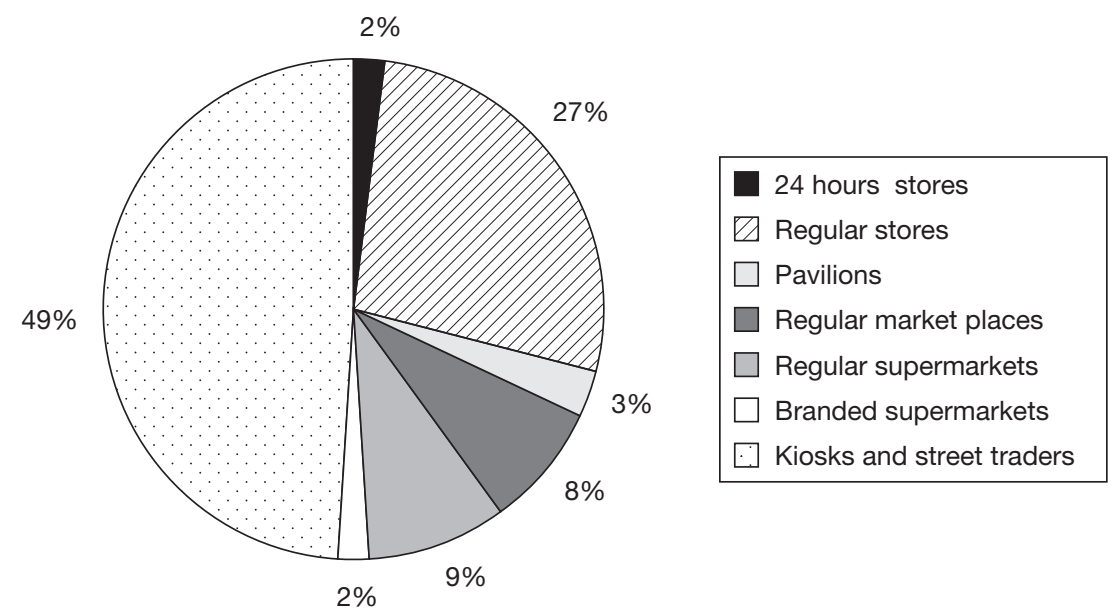

Figure 4.2 Percentage of purchases made from selected trading forms, St Petersburg, 1997

Source: Poll results by 'Krona Korsinta' (Komsomolskaya Pravda-St Petersburg, 11 April 1997).

the head of the Department of Trade in the city administration, Stepanov, revealed the absence - as late as 1995 - of centralized information on kiosks and a lack of understanding of the necessity to elaborate the city's programme for the development of kiosks and mobile forms. According to Stepanov, the city authorities generally favoured the flourishing of the kiosk trade in the city, since kiosks could solve social problems as well as compensate for the lack of trading space. The city authorities treated the kiosk phenomenon as a means to produce private capital and to provide new types of jobs, as well as a substantial source of revenue for the administration. At the same time, though, the authorities would have preferred to deal with fixed-space stores, since these could be better controlled and represented more 'civilized' urban forms.

By 1995, administrative policy was aimed at persuading kiosk traders to relocate their activities to fixed-space shops, by providing trading space in the ground floors of buildings, especially in residential areas (Figure 4.3).

In addition to this, the administration planned restrictions on the sale of certain types of goods from kiosks - starting with electronic goods and finishing with the most profitable items, alcoholic merchandise. The first regulatory actions taken by the administration in pursuit of this strategy did little to encourage kiosk traders to relocate to new fixed-space premises. In 1994-95 the authorities made the use of a cash register compulsory in all the kiosks and later prohibited the sale of alcohol from kiosks after 10 p.m. The effect of this was the emergence of fixed-space stores selling 


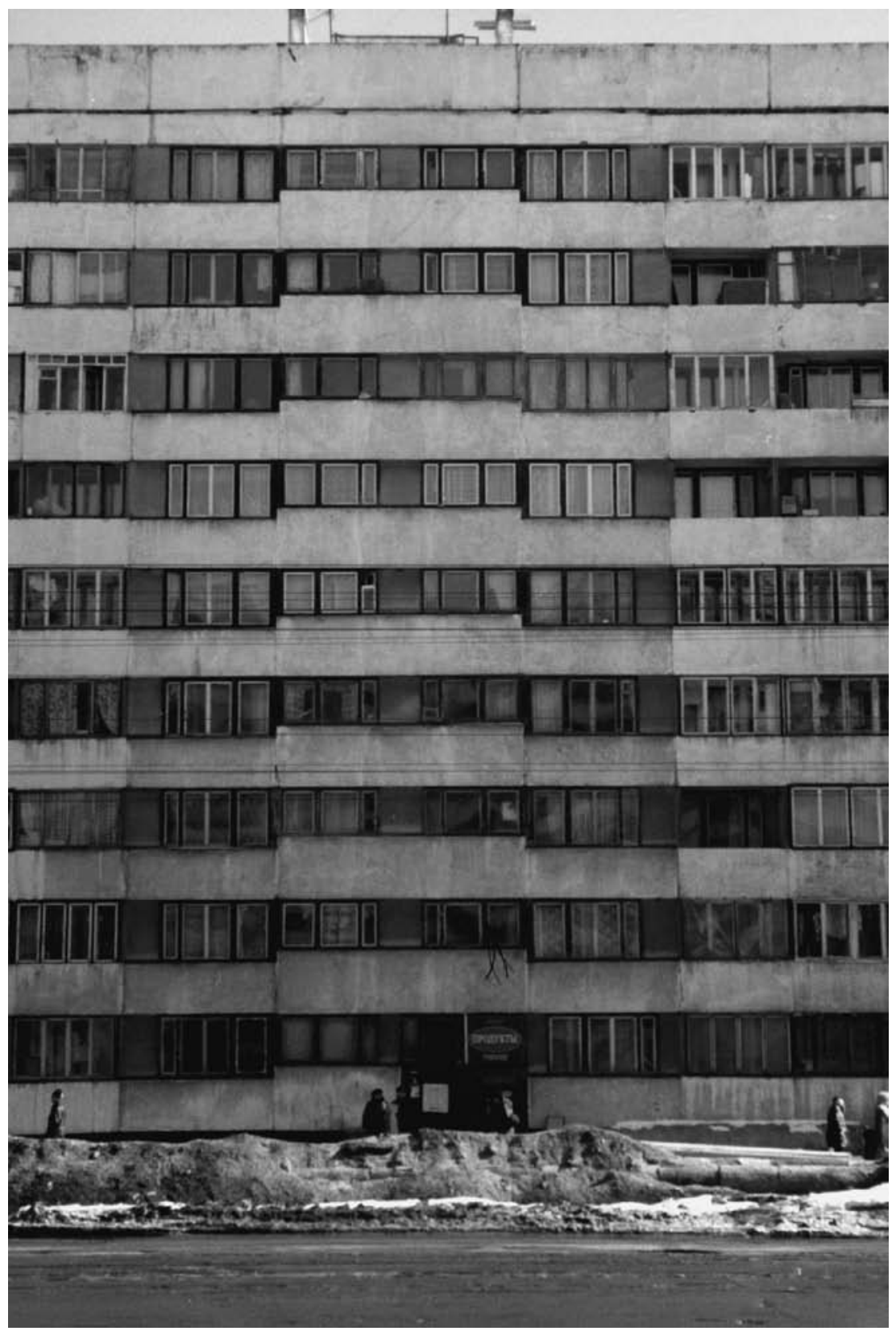

Figure 4.3 Food store on the ground floor of an apartment block near Primorskaya metro station, 1998

Source: Photo by K. Axenov. 
alcohol 24 hours a day and numerous violations of the rules by kiosks. Thus this first attempt to transfer the kiosk trade to fixed stores failed. This was due not so much to a failure of the authorities to implement their strategy in the proper way but rather to the fact that the goals of strategic planning were wrong. Kiosks and mobile forms provided consumers with a different shopping model than that of fixed shops, and neither traders nor consumers were willing to change this voluntarily. The period from 1989 to 1996 was the least regulated for the kiosks and mobile trade forms. But by 1996 the city authorities had begun to make the first distinct attempts to regulate the kiosks and mobile trade.

The different shopping model offered by kiosks in comparison to fixedspace shops makes the former crucially dependent on location. None of other factors - appearance, variety of merchandise, opening times or even price - have such importance for the survival of a kiosk or agglomeration of kiosks as location.

The main rule of the kiosk business can be formulated as follows: the closer kiosk trade is to the guaranteed flows of daily migrations, and the larger these flows, the more efficient it is. Location regulates the kiosk business at least on three scales:

1 The macro-location in different functional zones of the city regulates the potential capacity of a kiosk agglomeration. As we shall see, daily migration flows of equal volume can produce a different demand for kiosk agglomerations in different functional zones.

2 The meso-location within the main zones of the city regulates the size of kiosk agglomeration dependent on volumes of daily migrations.

3 The micro-location: within a kiosk agglomeration, the closer a kiosk is to the main routes of daily migration flows the more likely it is to survive. In this case a single metre can play a crucial role in survival.

\section{Macro-location}

The location of a kiosk agglomeration within the city has an important effect on the potential size of the agglomeration as well as on the variety of merchandise. Several parameters allow us to distinguish between kiosk agglomerations that are located in:

- exclusively residential, densely populated 'dormitory' areas;

- non-residential working areas;

- poly-functional zones.

The largest agglomerations in terms of the number of kiosks were found in 'dormitory' (or so called 'sleeping') areas near metro stations. This means that the most attractive locations for the kiosk business in the city lie on the routes between metro stations and people's homes. There are 
Table 4.1 Comparison of ridership volumes with size of kiosk agglomerations

\begin{tabular}{|c|c|c|c|c|c|c|}
\hline & 1989 & & 1994 & & & \\
\hline Metro station & $\begin{array}{l}\text { No. of } \\
\text { people } \\
\text { passing } \\
\text { daily } \\
\text { ('000) }\end{array}$ & $\begin{array}{l}\text { No. of } \\
\text { kiosks }\end{array}$ & $\begin{array}{l}\text { No. of } \\
\text { people } \\
\text { passing } \\
\text { daily } \\
\text { ('000) }\end{array}$ & $\begin{array}{l}\text { No. of } \\
\text { kiosks }\end{array}$ & $\begin{array}{l}\text { No. of } \\
\text { other } \\
\text { traders }\end{array}$ & $\begin{array}{l}\text { Macro- } \\
\text { location }\end{array}$ \\
\hline \multicolumn{7}{|l|}{ Vyborgski district } \\
\hline $\begin{array}{l}\text { Pr. Prosveschenia } \\
\text { Ozerki }^{\mathrm{a}} \\
\text { Udelnaya }^{\mathrm{b}} \\
\text { Lesnaya } \\
\text { Vyborgskaya }\end{array}$ & $\begin{array}{l}- \\
- \\
161.5 \\
67.3 \\
82.7\end{array}$ & $\begin{array}{l}38 \\
17 \\
30 \\
\mathrm{n} / \mathrm{a} \\
\mathrm{n} / \mathrm{a}\end{array}$ & $\begin{array}{r}125 \\
58 \\
60 \\
36 \\
38\end{array}$ & $\begin{array}{r}224 \\
127 \\
111 \\
30 \\
50\end{array}$ & $\begin{array}{r}132 \\
18 \\
131 \\
15 \\
5\end{array}$ & $\begin{array}{l}\text { A } \\
\text { A } \\
\text { B } \\
\text { C } \\
\text { D }\end{array}$ \\
\hline \multicolumn{7}{|l|}{ Smolninski district } \\
\hline $\begin{array}{l}\text { A. Nevskogo Square } \\
\text { Vosstania Square and } \\
\text { Moscow railway station }\end{array}$ & $\begin{array}{l}124.0 \\
120.4\end{array}$ & $\begin{array}{r}3 \\
42\end{array}$ & $\begin{array}{r}83 \\
106\end{array}$ & $\begin{array}{l}21 \\
90\end{array}$ & $\begin{array}{r}3 \\
35\end{array}$ & $\begin{array}{l}\mathrm{E} \\
\mathrm{E}\end{array}$ \\
\hline Ligovski $^{\mathrm{a}}$ & - & - & 88 & 3 & 0 & $\mathrm{C}$ \\
\hline \multicolumn{7}{|l|}{ Vasileostrovski district } \\
\hline $\begin{array}{l}\text { Vasileostrovskaya } \\
\text { Primorskaya }\end{array}$ & $\begin{array}{l}173.2 \\
110.7\end{array}$ & $\begin{array}{l}\mathrm{n} / \mathrm{a} \\
35\end{array}$ & $\begin{array}{l}165 \\
104\end{array}$ & $\begin{array}{r}38 \\
8\end{array}$ & $\begin{array}{l}46 \\
85\end{array}$ & $\begin{array}{l}\mathrm{E} \\
\mathrm{E}\end{array}$ \\
\hline
\end{tabular}

Source: Authors' survey. Ridership volume - Institute of City General Plan, St Petersburg.

Notes:

a These metro stations were built after 1989 .

b Both for metro and railway stations. According to the 1987 survey, during the rush hour of an average summer working day 15,000 people went through Moscow railway station and up to 14,000 through Udelnaya station.
A 'sleeping' area
B polyfunctional zone: housing area and transport node
C polyfunctional zone: housing area and working area
D working area with no housing
E polyfunctional zone with more than two functions.

kiosk agglomerations in the vicinity of almost all metro stations in the city. The possibility of measuring with a certain degree of reliability the passenger flows there, along with the substantial agglomeration size, makes these locations most interesting research objects. Table 4.1 shows the size of the kiosk agglomerations near metro stations in the rayons (districts) surveyed, the daily passenger flows and the functional zone of the city in which the agglomerations are located.

The very substantial reduction in the daily passenger flows at Udelnaya metro station between 1989 and 1994 is due to the extension of the metro line and construction of two new stations, Ozerki and Pr. Prosveschenia after 1989. When these stations opened, they took a substantial share of the passenger flows to the northern 'dormitory' areas away from Udelnaya. 
Not only do the kiosk agglomerations in the 'dormitory' areas have the greatest capacity (number of kiosks) as mentioned above, but they normally have enough free space to grow extensively, government regulation is less strict, and the range of merchandise available tends to be closer to that of big fixed-space stores.

Agglomerations in 'non-residential working areas' have the lowest capacity, merchandise usually is limited to everyday items, such as cigarettes, drinks, snacks, etc. It is obvious that people tend to do their major shopping on their way home - and as close to home as possible.

Agglomerations in 'poly-functional zones' serve flows of different types: people may live or work, transfer between different forms of transport, be on vacation or do their shopping there. These agglomerations combine features of both the previous types. Specialized merchandise, such as souvenirs, travel goods, etc., can be found there. These agglomerations are the most numerous in the city.

\section{Meso-location}

On the basis of our research we can rank meso-locations according to their attractiveness to the kiosk trade. The locations below are listed in descending order of relative attractiveness:

- metro and railway stations;

- fixed-space trading centres (their attractiveness depends on the size of a trading centre);

- public transport stops;

- crossroads and pedestrian crossings.

These locations guarantee a daily flow of people, making them ideal sites for kiosk agglomerations; the greater the number of people passing through a site on a daily basis, the greater the potential size of the agglomeration. There seem to be only three limitations on the growth of an agglomeration: the size of the daily flow; space; and administrative regulations. The relatively small size of the agglomerations near the A. Nevskogo and Ligovski metro stations (Table 4.1) are explained by the sheer lack of space. Due to the rise in criminal activity around Primorskaya station, the administration closed down the kiosk agglomeration there, which then relocated to the vicinity of the closest supermarket. Nevertheless, within a very short time the location became occupied by many semi-legal traders and - later - super mobile trading facilities that could be removed at night.

Comparative analysis of our 1989 and 1994 surveys revealed two tendencies in the spatial development of the kiosk business:

1 the emergence of new kiosk locations;

2 the quantitative growth of the existing agglomerations. 
Table 4.2 Data on type of kiosk agglomeration

\begin{tabular}{lrccc}
\hline Type of agglomeration & 1989 & 1994 & $\begin{array}{l}\text { \% of total } \\
\text { in 1989 }\end{array}$ & $\begin{array}{l}\text { \% of total } \\
\text { in 1994 }\end{array}$ \\
\hline Lone-standing & 36 & 206 & 14.4 & 12.7 \\
Small agglomeration (2-5) & 47 & 364 & 18.8 & 22.5 \\
Large agglomeration (6+) & 167 & 1,047 & 66.8 & 64.7 \\
Total & 250 & 1,617 & 100.0 & 100.0 \\
\hline
\end{tabular}

Source: Authors' survey.

The first tendency meant that there was an intensive search for new locations for kiosks. Normally, if one or two kiosks are able to operate efficiently at a new location, then a new agglomeration starts to develop there. Otherwise the kiosks disappear. Table 4.2 illustrates this: between 1989 and 1994 the shares of both lone-standing kiosks and kiosks located within big (more than six) agglomerations fell, while the share of kiosks located in small agglomerations grew.

The second tendency is more important than the first, since large agglomerations host the majority of the city's kiosks (Table 4.1). Figure 4.4 shows the economically most favourable and attractive locations for the kiosk business in one of three rayons studied.

The largest agglomerations could be found near metro and railway stations. The vicinity of the Pr. Prosveschenia metro station hosts more than 200 kiosks. The map also shows the locations where demand for kiosk trading facilities is still higher than supply. Where the number of individual traders with no or poor facilities is high, this means that the number of kiosks there is low. In time these traders tend to be replaced by kiosks.

\section{Micro-location}

Between the 1989 and 1994 surveys, substantial shifts took place within the biggest agglomerations, which indicate the spatial consequences of certain tendencies. In order to clarify these tendencies we undertook an additional survey in 1995. Of specific interest to us were the largest agglomerations that had no administrative or spatial limitations on their extensive growth and, hence, that developed in more free market conditions.

The dynamic comparative study led us to conclude that all agglomerations that had no limitations on their growth developed through the same stages:

\section{Stage of under-saturated agglomeration}

This stage is characterized by the rapid growth of the number of kiosks, and even more importantly, semi-legal private traders with lightweight 


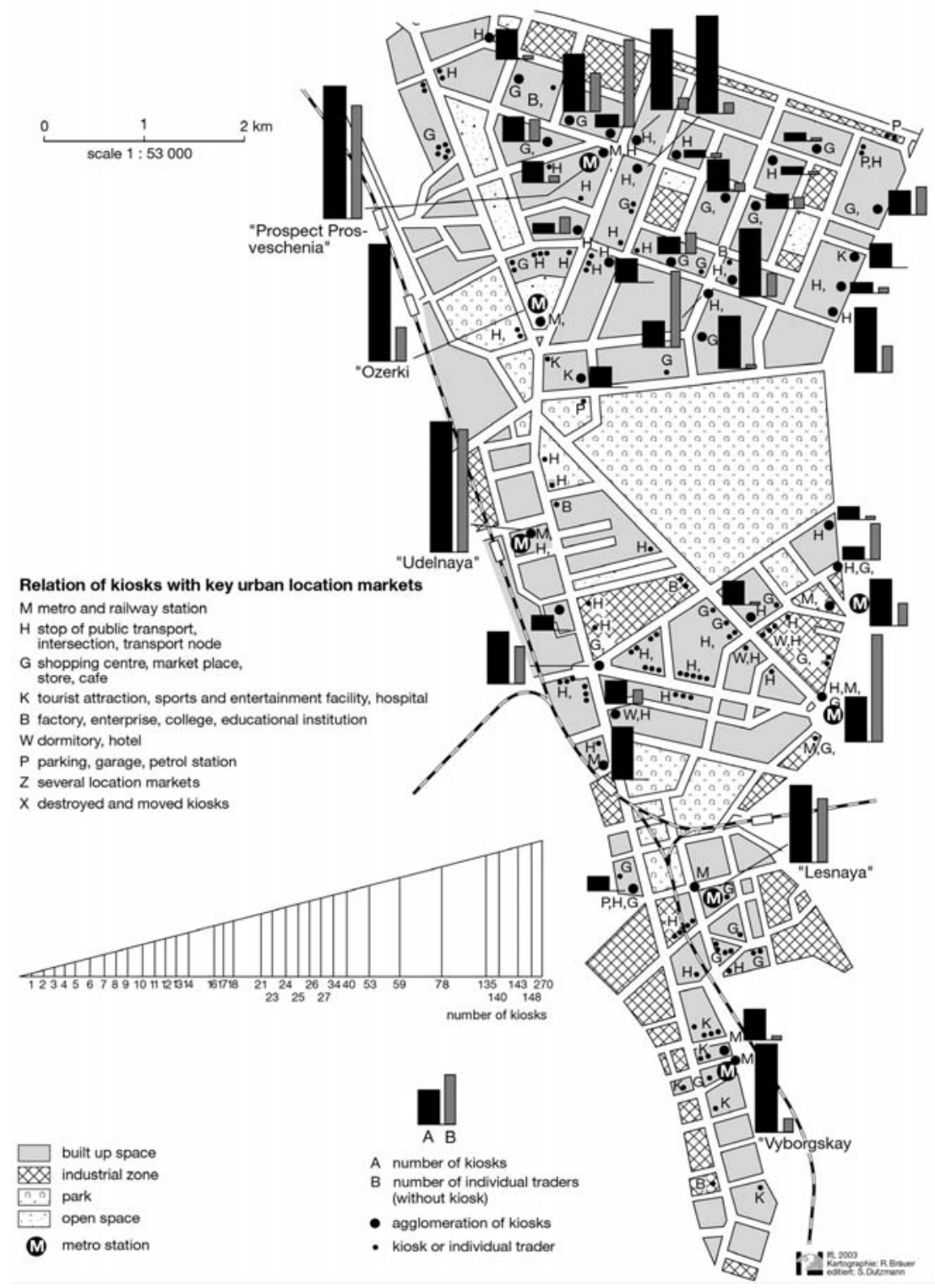

Figure 4.4 Location of kiosks and individual traders in Vyborgski district, 1994 Source: Axenov, Brade and Papadopoulos, 1997. 
stands or without any facilities at all. The more such traders observed the less saturated the agglomeration is, and the greater the potential for its extensive growth. As a rule, in such agglomerations there are few kiosks specializing in one kind of merchandise. A large number of closed kiosks are likely to appear, which have been set up for the sole purpose of occupying a potentially favourable location until commencing operation at a later date. At this stage, trading positions are usually located along the routes of the most intensive flows (Figure 4.5a).

\section{Stage of mechanical saturation}

The main indicator of this stage is the closing of the least conveniently located kiosks and a slight decrease (or absence of growth) in the number of individual traders. At this stage, the geometrical location of facilities can be observed - stands or kiosks are arranged in parallel rows or squares like a mini-market. Such forms indicate the first spontaneous attempts to replace the kiosk shopping model of 'on the way' with a more traditional store-market place one, which attempts to make consumers come specially to the trader, although not forcing them to deviate far from their route (Figure 4.5b).

\section{Stage of oversaturated agglomeration}

This is the stage of the reordering of space and intense competition for location. The number of kiosks closed due to inefficiency in the less convenient locations grows. The regular, geometrical forms of trading rows disappear. They are replaced by 'irregular' trading rows that have been moved closer to the migration flows. Micro-migrations, measuring just single metres, become crucial as kiosks and traders attempt to get closer to the main routes taken by potential customers. The most interesting phenomenon is the revival of the less convenient locations. They become occupied by kiosks specializing in one type of merchandise (bread, dairy products, etc.). These kiosks tend to attract consumers like mini-stores. At first glance, the tendency of several competing kiosks specializing in similar merchandise, to concentrate in an unfavourable location seems rather paradoxical. In fact, this appears to be the best way to survive in the inconvenient locations. For example, in one particular agglomeration a row of five or six kiosks, all selling meat products of the same variety, appeared in an unfavourable location where previous kiosk traders had failed. Consumers then are expected to make a special effort to go to this location. What is favourable, and attracts the consumers in this case, is the knowledge that they can choose meat from different competing traders. Competition means that prices are lower in comparison to stores and other traders. Our guess would be that any meat store opening close to this agglomeration is likely to fail, because without the variety of competing 


\section{Specific forms of spatial saturation}

goods and, hence, low prices to compensate for the locational inconvenience, it will be unable to attract people away from their daily routes.

\section{The first stage of administrative restructuring, 1996-98}

By 1996, kiosks and mobile forms had become one of the major trading structures in the city. At the same time, however, the seven years of their

(a)

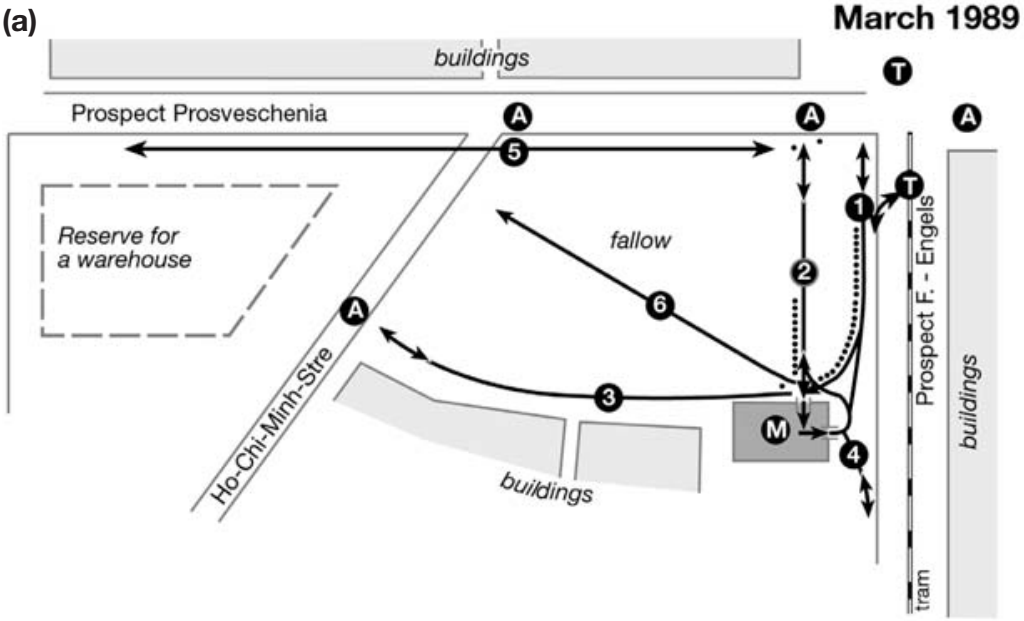

(b)

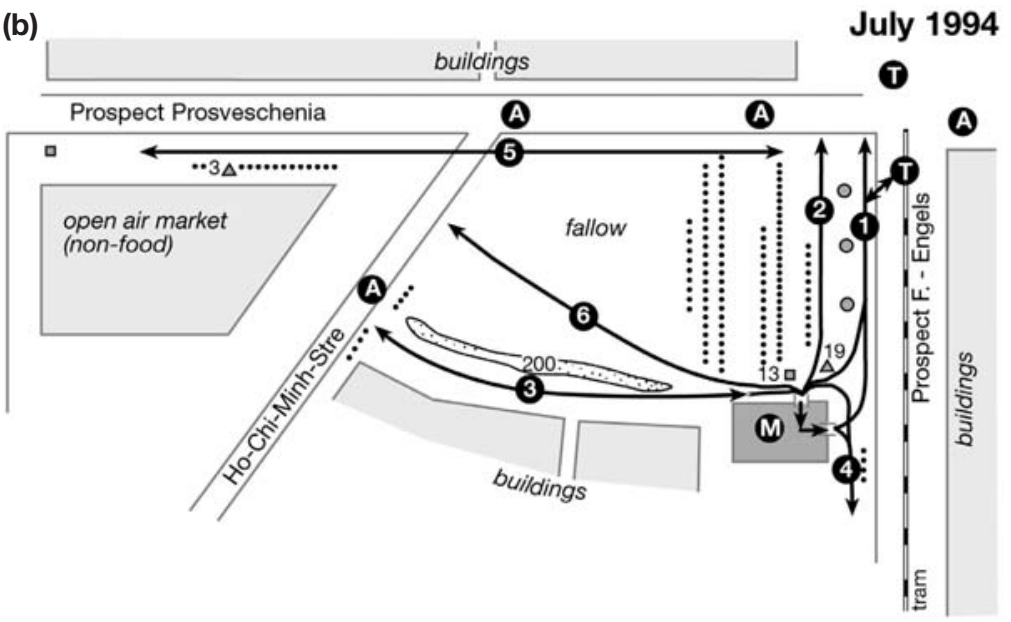

Figure 4.5 St Petersburg, Prospect Prosveschenia. (a) Stage of under-saturated agglomeration, Pr. Prosveschenia case, 1989. (b) Stage of mechanical saturation, Pr. Prosveschenia case, 1994 
(c)

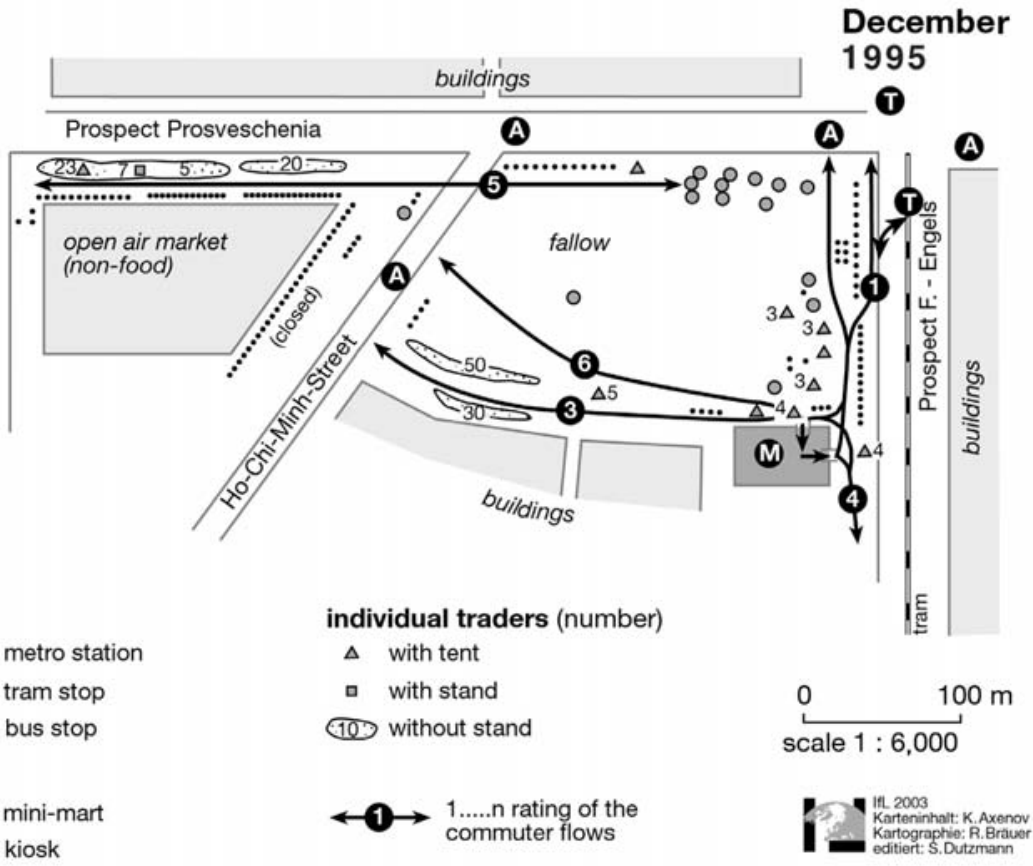

Figure 4.5 (cont.) (c) Recasting of an agglomeration, Pr. Prosveschenia case, 1995

operation had led to the emergence of new private actors with enough capital to invest in larger-scale projects. Furthermore, the consumption capacity of the population in general had grown, and the social stratification of society had started to become pronounced. The 'kiosk empire', in its given form, was no longer vital to the city - kiosks had produced the new capital, the demand was no longer just for lower-cost and lowquality goods, and sanitary and other legal norms, as well as the appearance of the cityscape, became issues. Thus in 1996 the city authorities launched the first major offensive against kiosks. The goals for this campaign were as follows. The authorities declared that they aimed to establish tighter control over the small retail trade in order to minimize activity in the shadow economy and criminal activity related to it and so raise budget revenues. The administration made the violation of sanitary norms and the blighting of the city's appearance by the small retail trade an issue for public discussion, initiated by administration. All the plans were declared to be aimed at providing the city's consumers with higher-quality products and better standards of service.

Unlike before, administrative strategy was not based upon the desire simply to relocate kiosk trade to fixed stores. Such a strategy could not 
provide consumers with the main benefits offered by kiosks and mobile forms - spatial accessibility and lower prices. This time, the administration decided to preserve these benefits within the market, although separating them in space. Two major new trade forms were to replace kiosk agglomerations and trade zones - pavilions and market(place)s.

Pavilions were to replace the kiosks on the site of agglomerations. Pavilions were, in fact, small, low-cost shops providing better exposure of the merchandise than regular stores but having a trading hall and generally offering a better quality of service for the consumer than kiosks. The administration gained much greater control over the trading activities in the permanent pavilions than was the case with kiosks and street traders. Both the appearance of the city and sanitary standards improved. Whereas the term of the lease for kiosk space was for no more than a year, the term for leases in pavilions was no less than three years and a permit was required. In fact, the pavilions were a means of converting the temporary commercial locations previously explored and exploited by kiosks and mobile traders into new permanent trading spaces that formed part of the city's commercial real estate market.

However, two problems remained. The capacity of the pavilions was many times less than that of the trade zones they were to replace. This meant that new pavilions could serve far fewer consumers daily than a trade zone did. Furthermore, the business costs associated with a pavilion, although lower than for a fixed shop, were still much higher than for a kiosk. Less intense competition than in a kiosk agglomeration, the higher business costs and fewer possibilities for activity in the shadow economy inevitably made merchandise in a pavilion more expensive than that of a kiosk. Hence, although the pavilions inherited the kiosks' locations and could satisfy the 'kiosk' type of shopping model, they failed to satisfy the demand for a variety of merchandise and trading space, nor could they provide the lowest prices.

The administration attempted to solve these problems by establishing market places, new trading grounds to host kiosks and mobile traders from the former trade zones near metro stations, etc. In fact, this constituted the administrative relocation of small retailers from the most profitable commercial locations distributed all over the city's territory, and their concentration on new sites. This was mainly done via economic tools rent regulations and creating new locational choices - in addition to direct restrictions. This was quite a risky endeavour - as with previous attempts to transfer small retailers to fixed stores, it might have faced the refusal of both traders and consumers to change the existing shopping pattern. In reality, such a programme meant the restructuring of the largest segment of the city's retail sector and the modification of the shopping practices of the majority of the population. The proposed transition from kiosks and trade zones to pavilions and open-air markets implied that those consumers who seek the cheapest merchandise would travel specially to the 
new locations, while those who were ready to pay more would use the pavilions and fixed stores. This appeared to be a distinctive administrative attempt at the social spatial segregation of consumers. It is important to note that the transportation pattern basically remained the same and that the majority of the city's population continued to use public transport as their main means of transportation.

\section{How were these plans implemented?}

The first stage of administrative restructuring involved several phases and measures. After testing public attitudes towards the strategy, and realizing that the social consequences could not be predicted in full, the city administration decided to delegate the executive initiative for the implementation of reform to its regional branches. These branches were, in fact, regional departments of the city administration, but since they had represented formally independent power agencies during the socialist and 'perestroika' eras, people still did not really associate them with the central city authorities. This potentially allowed the city government to distance itself from possible public dissatisfaction with the results of small retail trade restructuring.

In the different administrative regions, the regional authorities applied different tactics and set different paces of restructuring. In Nevski rayon, for example, the authorities managed to remove the vast majority of the kiosks, i.e. about 1,400, within the year 1996 alone. There, the municipal authorities invested in the construction of the new market grounds themselves, thus trying to control the location process fully. At the same time, in our case study area - Vyborgski rayon - the authorities preferred to stimulate private initiatives to redevelop the trade zones and set up the new market places. This resulted in a somewhat slower pace of development: by the beginning of 1997 - i.e. within a year and a half - they had managed to relocate/remove about 800 kiosks (Sankt-Peterburgskie Vedomosti, 27 February 1997).

The respective laws and regulations were issued to establish standards and norms for the trade zones, pavilions, kiosks, markets, etc. These included not only sanitary, operational and engineering norms but also standards of appearance. ${ }^{4}$ Minor regulations were introduced that applied to the quality of service, ${ }^{5}$ fiscal procedures, etc.

One of the most significant pieces of legislation introduced by the City of St Petersburg Administration was the law 'On the conditions applying to the retail trade in alcoholic merchandise in St Petersburg', adopted in June 1997 (Sankt-Peterburgskie Vedomosti, 27 February 1997). Primarily, it restricted the sale of strong alcohol to establishments with a trading hall. This meant that while pavilions were allowed to sell liquor, kiosks were not. It also contained certain territorial restrictions, in fact prohibiting the sale of alcohol (with the exception of beer) near metro stations, many 
public buildings and even at the open-air markets. This law had a very pronounced effect on the spatial redistribution of retail trade in the city and helped to minimize the illegal circulation of alcohol, as well as improving controls over the quality of alcoholic merchandise. The implementation of this law generally achieved its major goals. What is of more interest for us here is that most of the trade in alcohol was steadily moved to the fixed stores and pavilions, giving them a serious market advantage over other trade forms, which were left with certain specialized segments of the retail market only. Quite surprisingly, the implementation of this regulation was quite a peaceful process, which could mean that kiosk operators were economically and physically ready for the restructuring of their business.

Since August 1997, the sale of certain goods, including most food stuffs and manufactured merchandise, in small retail has been prohibited by decree of the Governor. Special rules applied for certain areas, such as railway and metro stations, and airports. If the 'alcohol trade' law discriminated mostly against kiosks and open-air markets in favour of pavilions and fixed stores, this decree was aimed at restricting the smallest retailers - street traders selling from counters, boxes, or without any equipment at all. This regulation effectively put an end to thousands of small businesses without providing any real alternatives for the operators, and inevitably caused significant civil unrest. Private traders protested about it for quite a long time. In just one of the hundreds of trade zones that existed in the city about 500 people were employed in small retail, although this was not necessarily their only source of income (Sankt-Peterburgskie Vedomosti, 21 August 1997). The administration was forced to delay the implementation of this regulation several times while compromises with the traders were achieved, by which time they estimated that there were about 6,000 kiosks and pavilions in the city, located within or outside 420 trade zones (SanktPeterburgskie Vedomosti, 5 September 1997). ${ }^{6}$ The administration aimed to remove all the kiosks by the summer of 1998 , except those selling dairy products, and bread, cakes and pastries.

Although these plans failed to be implemented in full, the results of administrative efforts were impressive. For example, during the course of October 1997, 31 kiosks (about one-third of the total number by that time) and 113 small 'countered' traders (about 60 per cent) were removed from one of the central city districts (Admiralteiski). During the same period 18 new fixed trading facilities and 9 cafes opened in this district (Petrovski Kurier, 18 November 1997, regional edition). In another central district (Petrogradski), 280 kiosks disappeared and several markets and pavilion complexes emerged during 1997 (Sankt-Peterburgskie Vedomosti, 14 March 1998). By November 1997, just a few months after the protests had begun, the most critical phase of public opposition to the small retail trade reforms had passed. This constituted a sort of victory for the administration, which opened way to proceeding with their further plans. 
In 1998 administrative restructuring continued. The administration's first major objective was to remove all the kiosks and small retail traders from the streets and to restrict them to the specialized market places. As in the socialist era, the administration issued a list of specialized trades permitted to operate via kiosks. These were the press and shoe repair, which had been traditionally located in kiosks since socialist times, as well as dairy products, and bread, cakes and pastries. Their second objective was to redevelop the old trade zones and markets, and to open new ones. In general these goals were achieved. The 'kiosk empire' ceased to exist.

Another detail of importance to our discussion is the fact that while larger kiosk agglomerations were quite easily replaced with pavilions, isolated kiosks remained a problem at certain locations. The main rule of the kiosk trade still applied, and consumer demand for kiosk-type trade was still heavily dependent upon the volumes of daily commuters. At many public transport stops, daily commuter volumes, while enough to support the existence of one or two kiosks, were insufficient to support a pavilion. At first, kiosks were swept away from such locations as well. But later, in acknowledgement of public dissatisfaction and the continuing demand for kiosk trade at public transport stops, the administration launched a programme aimed at replacing 3,000 of the old bus and tram stops with new constructions containing built-in kiosks and outdoor advertisement booths. Commenting on their decision to merge kiosks with constructions at bus and tram stops, city officials referred to the resulting facility as an 'inevitable evil' (Izvestia-Peterburg, 23 April 1998). By the end of 1998, this programme had been generally fulfilled. This meant that the administration was forced to recognize the necessity of the kiosk trade as well the importance of the kiosk type of shopping.

What were the major outcomes of this stage, in terms of the development of spatial structures?

Administrative restructuring started with testing the strategy as early as 1995. This testing took place at several locations throughout the city, one of the first being our case study, the Pr. Prosveschenia trade zone. Thus in 1995, the agglomeration of kiosks and mobile traders there was replaced by a set of new pavilions (Figure $4.5 \mathrm{c}$ ).

Several reasons made this particular site the ideal place for such an experiment. First, Pr. Prosveschenia was one of the most advanced trade zones in the city, in terms of its size, stage of development and economic performance. Second, due to its level of development and economic performance, some operators in this trade zone had acquired sufficient capital to be in a position to invest in its redevelopment. Third, it was one of the few cases where a large open-air market had already been established in close proximity to the zone. This locational advantage enabled the authorities to test the strategy relatively effortlessly on a small scale, as the new market place did not have to be established and promoted, and kiosks and 


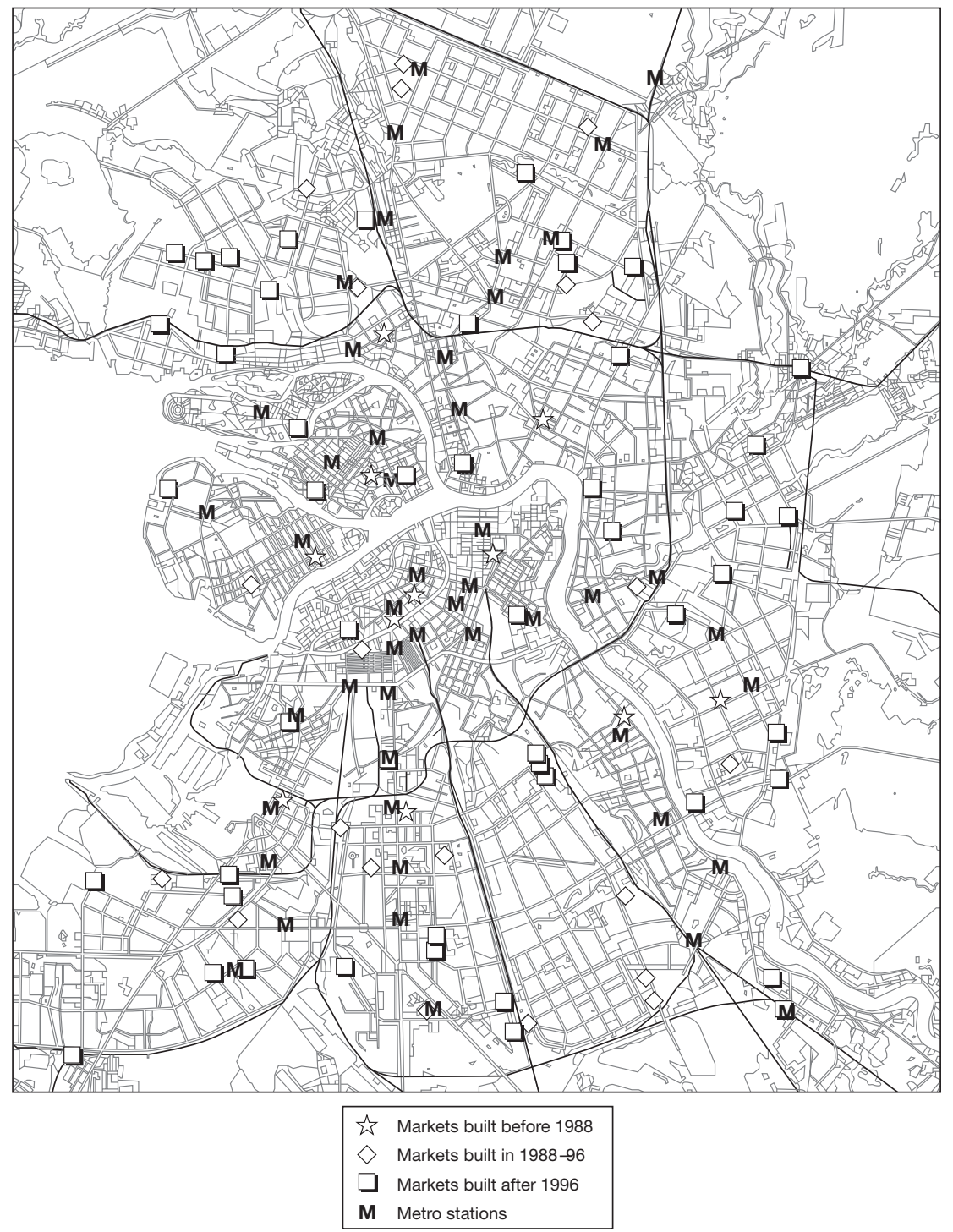

Figure 4.6 Market place development in Leningrad-St Petersburg 
other traders did not have to be relocated too far away from their former trade zone.

So, in 1995 about 200 kiosks were relocated to the neighbouring openair market. As we have outlined before (Axenov, Brade and Papadopoulos, 1997), many of the relocated kiosks ceased trading altogether.

This first experiment turned out to be a success, and commuters/ consumers finally accepted the split between the convenient pavilions 'on the way' and the cheaper market place not far away. From 1996, this practice was extended on a city-wide scale, although the newly established market places were not necessarily located in the closest vicinity of the former trade zones. In some areas of the city people had to travel quite far by public transport or even by car to the cheaper open-air markets. The location of these markets was governed by the availability of waste land in close proximity to public transport nodes. Many of the new openair markets appeared at the very edges of the city, near the last stops on public transport (Figure 4.6). In total, 80 new markets have appeared in the city since 1988 .

The first stage of administrative restructuring generally exhibited very dynamic rates of change in spatial structures.

\section{Pavilions and markets stage, 1998-2001}

By 1998, the implementation of the small retail trade restructuring campaign had radically changed the cityscape. Kiosk agglomerations and small retail trade zones were replaced by pavilions at the same locations, and numerous large market places emerged all over the city. This seemed to be an administrative triumph by the authorities. But steadily market forces started to 'improve' the new spatial pattern 'built' by administration. Pavilions that emerged at the busiest commercial locations failed to compensate for former kiosk agglomerations and fully satisfy the demand for 'kiosk-type' shopping. According to our surveys, there were 1,016 kiosks in the Vyborgski district in 1994. After administrative restructuring, this district hosted 237 pavilions occupying a total area of about 13,500 square metres. They varied in size from almost 500 square metres with numerous entrances to little bit bigger than a kiosk. Some 290 traders operated in these pavilions. In order to make at least a rough comparison of the trading capacity of kiosks in 1994 and pavilions in 1998, we estimated the showcase (shop window) area of kiosks and pavilions respectively.

The total showcase (shop window) area of all traders in the pavilions in 1998 was 4,277 square metres. The average shop window of a kiosk is about 9 square metres. This means that in 1998, the pavilions could theoretically exhibit the merchandise of 475 kiosks, which is about 47 per cent of the number of kiosks in 1994. ${ }^{7}$ Showcase (shop window) area per individual trader in pavilions differed significantly. Of the traders we 
Table 4.3 Showcase (shop window) area of separate traders in pavilions, 1998

\begin{tabular}{lc}
\hline $\begin{array}{l}\text { Showcase (shop window) } \\
\text { area }(s q \mathrm{~m})\end{array}$ & $\begin{array}{l}\text { Number } \\
\text { of traders }\end{array}$ \\
\hline $0.1-3$ & 15 \\
$3.1-9$ & 33 \\
$9.1-20$ & 122 \\
20.1 and more & 63 \\
Total & 233 \\
\hline
\end{tabular}

Source: Authors' field survey in the Vyborgski district, 1998.

surveyed, 15 had a showcase area of less than 3 square metres, comparable to that of a street trader rather than a kiosk, 33 were limited to the show area of an average kiosk, but the majority, however, had a much greater showcase (shop window) area than a kiosk (Table 4.3).

All this evidence suggests that if the 'kiosk-type' shopping remained, the pavilions could have by no means satisfied the demand that had been served by kiosks and small retailers before the administrative reforms of 1996-98. Indeed, the desire to shop on the way home still prevailed for the majority of the city's population. They could not afford to lose time travelling by public transport to the markets or queuing in the pavilions. And the market responded to this.

Since regulations did not permit the sale of goods from kiosks or simple counters in such locations, a new type of mobile trading facility emerged - the 'tent'. Operating from tents meant that traders avoided the restrictions applied to the 'unsheltered' street traders and were able to sell a much wider range of merchandise. At the same time, in contrast to kiosks there was no need to rent land or establish more or less permanent constructions. In order not to fall under regulations, tents were erected in the morning and removed in the evening. In fact, they represented an intermediate trade form between the small retailer and the kiosk. In a very few cases auto-shops performed as daily mobile trading facilities, but being much more costly they eventually disappeared.

Tents as well as individual illegal traders appeared around the pavilions at the very same locations where kiosks had been previously, but they also became widely used at the open-air markets (Figures $4.7 \mathrm{a}-\mathrm{c}$ ).

The major declared objectives of the restructuring campaign, which had seemed to have been reached, turned out to be failures - neither sanitary norms nor the appearance of the city improved, and shadow or illegal trade operation came back to the streets, though to a much lesser extent. Tents and shadow/illegal private traders became an integrated part of the city's retail landscape along with pavilions and open-air markets (Figure 4.8). 

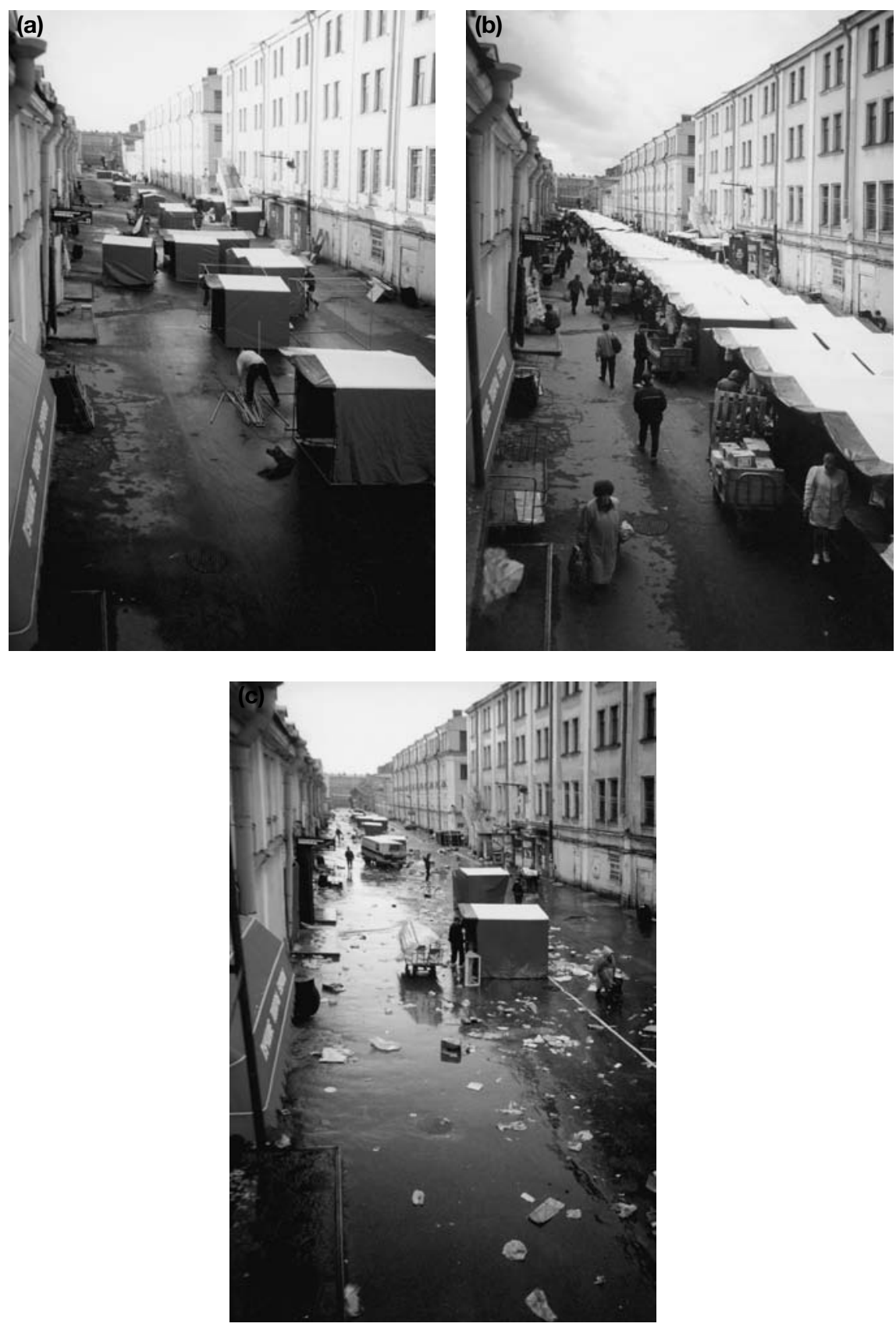

Figures 4.7 Tents at Apraksin Dvor open-air market: (a) at 7.50 a.m., before opening; (b) at 9.42 a.m., working hours; (c) at 6.32 p.m., market closed Source: Photos by F. Krenev. 


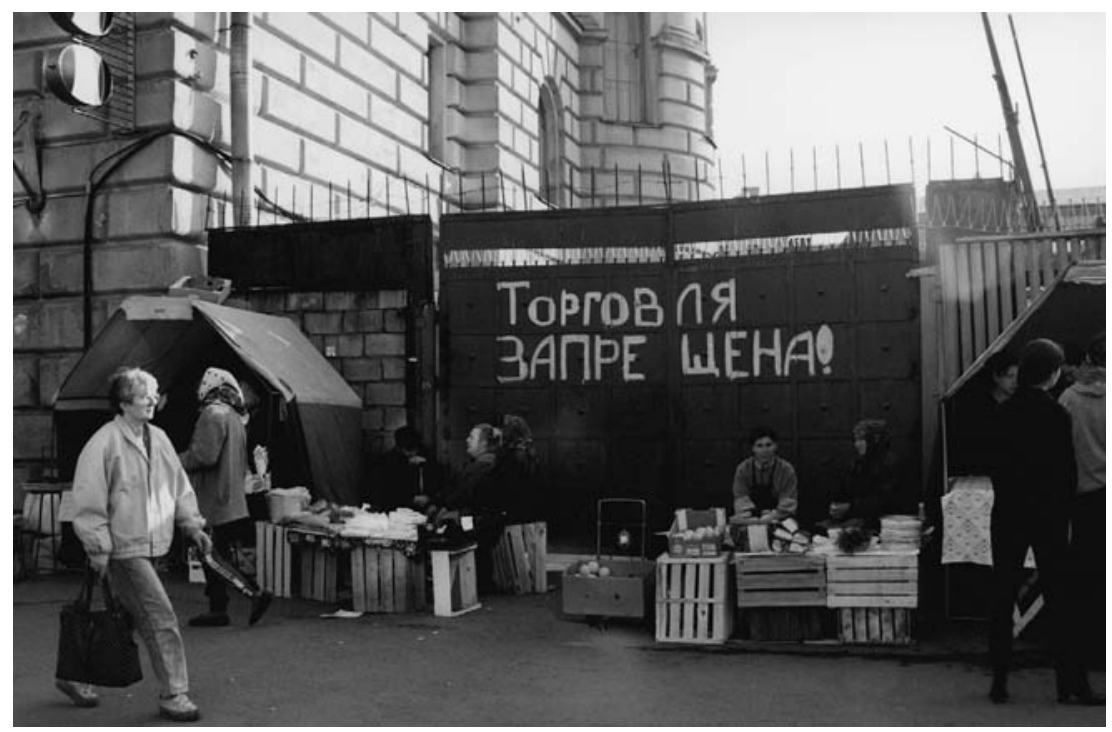

Figure 4.8 Illegal private traders, 1998; the sign on the wall reads: 'Trade forbidden'

Source: Photo by F. Krenev.

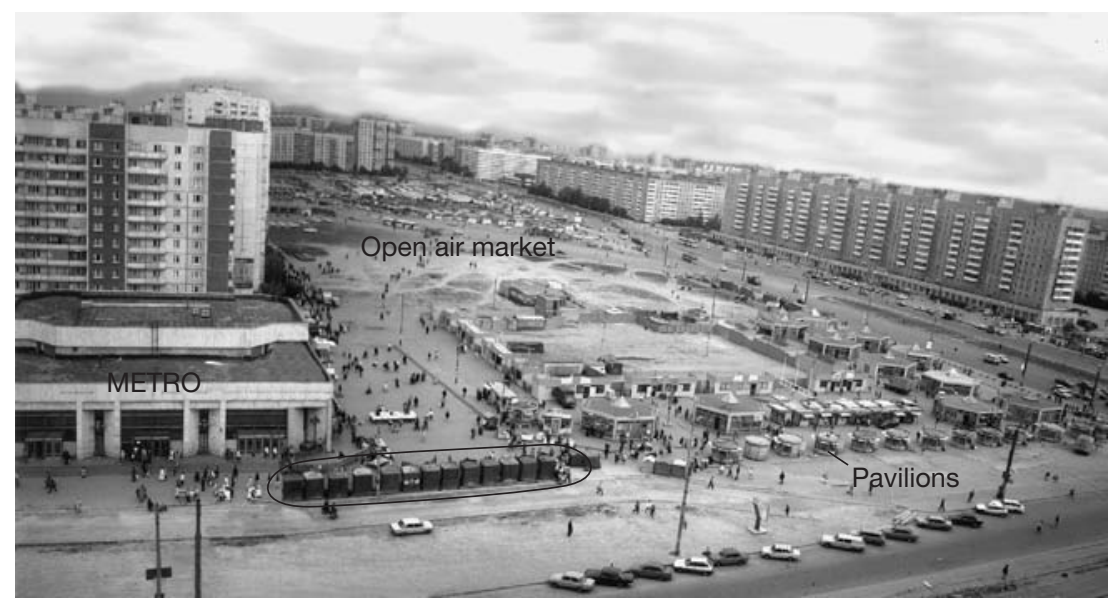

Figure 4.9 Pr. Prosveschenia agglomeration after the kiosks were removed, July 1996; the metro station is the building on the left; the future construction site of a trade complex is surrounded by pavilions and temporary facilities; in the background is the open-air market place; the tents at the most favourable location are circled

Source: Photo by I. Brade. 


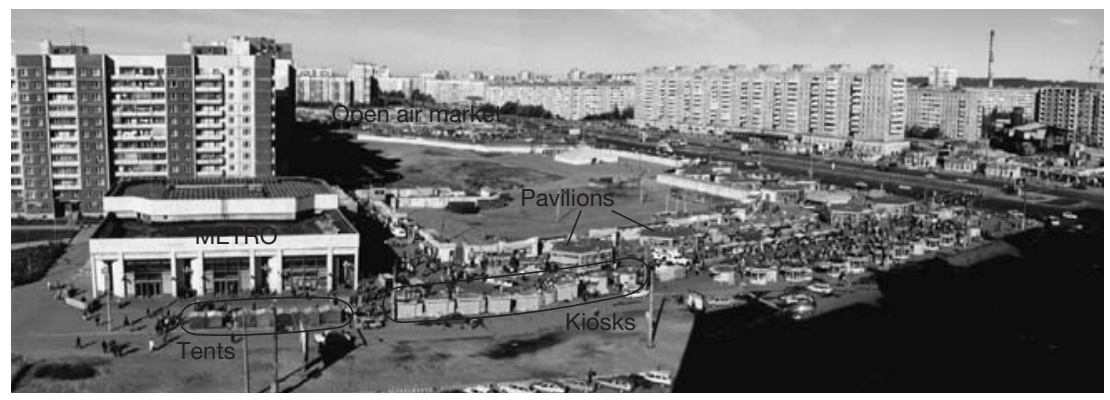

Figure 4.10 Tents migration at Pr. Prosveschenia agglomeration, 1998; the area where the tents were replaced by new kiosks in the most favourable location and the area to which the tents were moved are circled

Source: Photo by I. Brade.

As soon as the kiosk agglomeration at Pr. Prosveschenia was removed, tents appeared there almost at once (Figure 4.9). Initially, the tents tended to occupy the best locations closer to the metro station exit, as happened with the first kiosks in 1989. This proves that the demand for such a shopping model remained. By 1998, the same most favourable micro-location, which had been occupied by tents in 1996, had become, once again, the location for kiosk-type constructions. The tents were moved to the less favourable location near the entrance to the metro station (Figure 4.10). ${ }^{8}$

Along the traditional paths followed by commuters, a new trade zone consisting of tents, kiosks and individual traders developed. The city authorities had to tolerate this, since at that time they were unable to offer another solution and they preferred to focus on tightening fiscal, sanitary, etc. control. In 1999 they decreed that each kiosk, pavilion and some other trade operators should possess the 'technical passport' for their constructions. This 'passport' was introduced to help ensure the compliance of the traders with all the relevant norms. The possession of such a 'passport' became a sort of operating permit for each construction. Pavilions, for example, had to apply for a new 'passport' every three years (Sankt-Peterburgskie Vedomosti, 5 May 1999).

Comparison of the distribution patterns for 1994 and 1998 shows that the system of commercial locations explored by kiosks during the first stages of transformation was generally inherited by the new forms as well. Each pavilion agglomeration hosted a substantial number of individual small retailers. Administrative restructuring resulted in significant changes in the structure of merchandise offered by kiosks in 1994 and kiosks/ pavilions in 1998 (Figure 4.11, Table 4.4).

Due to the dramatic reduction in the number of kiosks and the effects of administrative regulations, the percentage of traders selling the traditional kiosk stock - alcohol, cigarettes and snacks - declined substantially. 


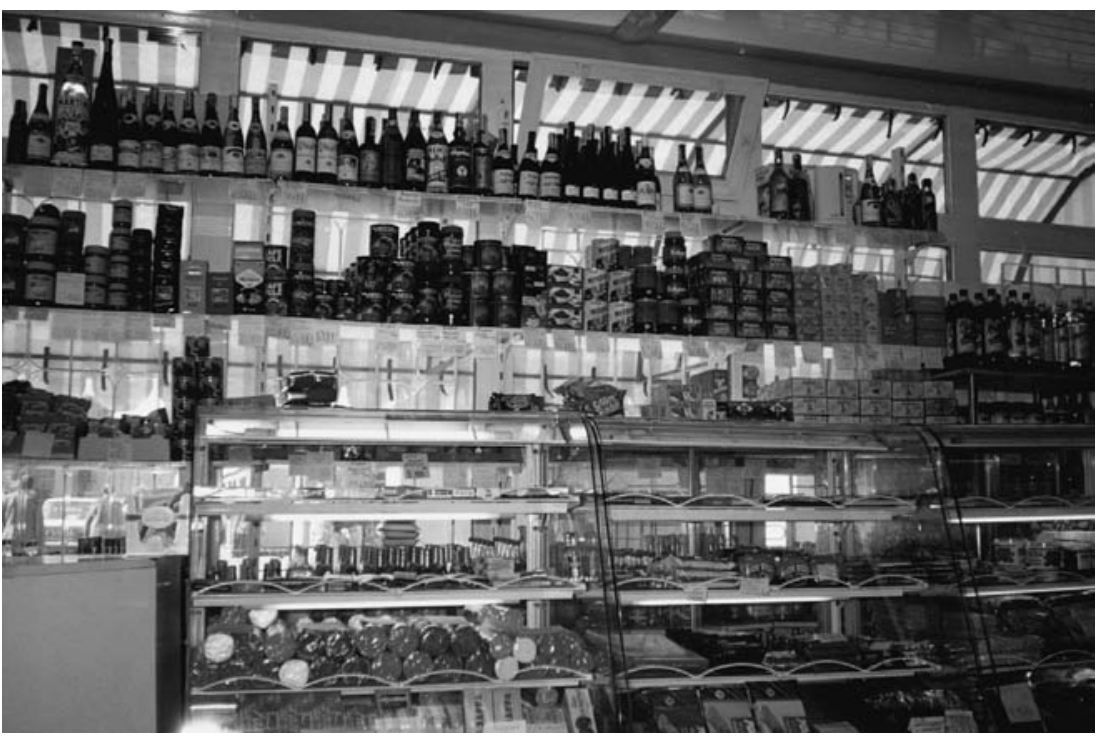

Figure 4.11 The interior of a pavilion at Pr. Prosveschenia, 1998

Source: Photo by K Axenov.

The percentage of traders selling most other forms of merchandise declined as well. Administrative reform resulted in an increased share of facilities selling fruit and vegetables, dairy products and fast food.

\section{Development of larger permanent trade forms, 2001-02}

The first attempts to transform the open-air markets and trade zones that had not been successfully relocated into covered trade complexes and designated market places were initiated by the authorities as early as 1997-98. Most such complexes were located at very favourable commercial spots, and in 2002 some of them still survived. But these efforts failed to become a full-scale process in 1997-98, since investors were not prepared to put large sums into real estate development in such zones.

However, the retail trade seemed to benefit from the financial crisis of 1998, and by 2001 investment capital was available for the development of larger trade forms than pavilions and markets. Significantly, this investment capital had usually been generated in the former small retail zones by kiosk and pavilion operators. The administration supported the desire of some operators to convert the pavilion agglomerations into larger fixedtrade complexes. Competition between market places also forced certain market operators to invest in building permanent constructions for their markets, in order to offer a better quality of service. Several administrative 
Table 4.4 Data on merchandise sold in kiosks/pavilions, Vyborgski rayon, 1994-98

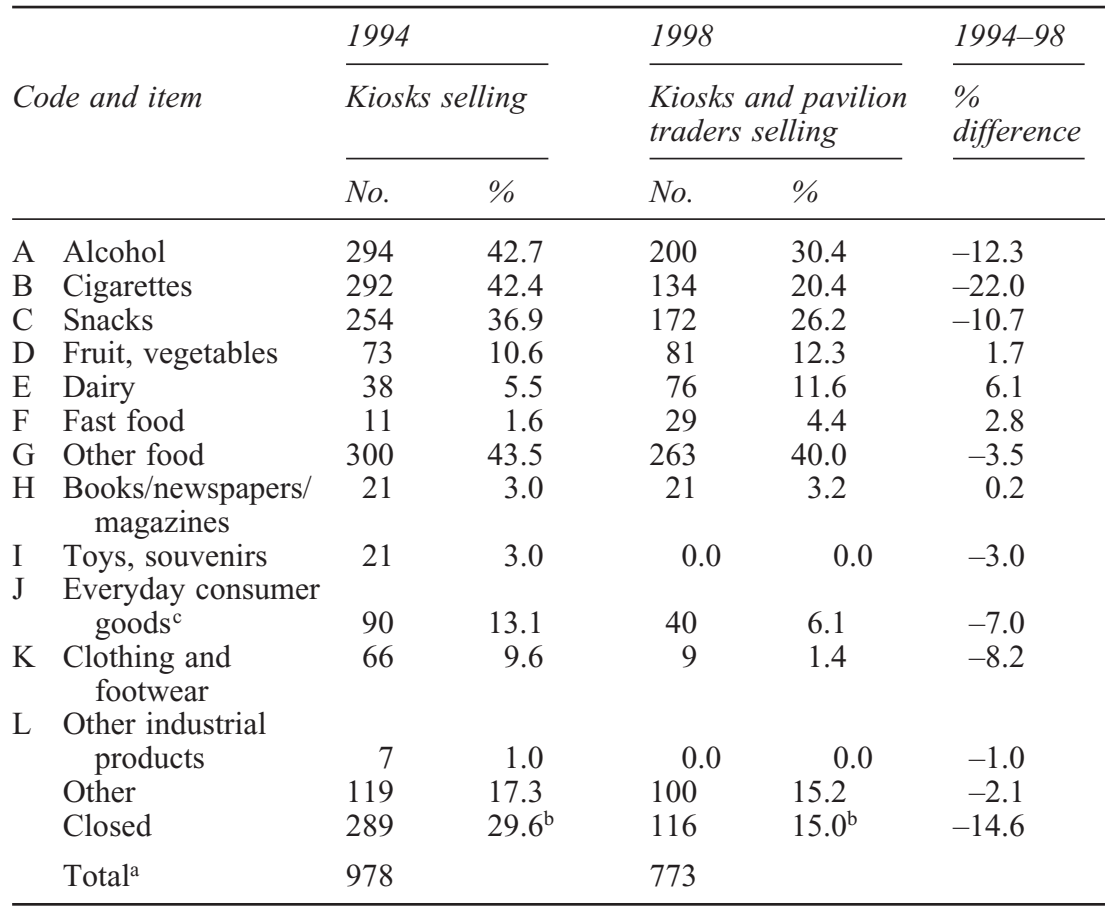

Notes:

a Total does not include those closed.

b Total includes those closed.

c Except clothing and footwear.

Totals may exceed $100 \%$ due to traders selling more than 1 item.

regulations that applied in 2001-02 - at both the federal and the local level - favoured larger capital investments in the retail business.

Very important regulations were issued at the federal level regarding one of the main sources of merchandise supply for the small retail trade since the early years of transformation, the 'shuttle' import of goods. Hundreds of thousands of individual traders import various types of merchandise in quantities that can be carried as personal luggage on trains, buses and planes. ${ }^{9}$ During the early transformation period, this type of commerce was a way of preventing economic disaster for many Russian families, since it supported the development of the small retail and kiosk trade and thus performed a major social role. Ten years later, the benefits of this type of operation were economic rather than social.

According to the norms that applied as late as 2001, customs duty on goods imported in volumes weighing less than 200 kilograms or below 
the value of US\$10,000 was charged at only 30 per cent of the rate for larger volumes of the same merchandise. Experts consider that the individual 'shuttle' operators of early transformation period have almost ceased to exist. They were replaced by cargo companies, which operated using the 'shuttle' tariffs. The extent of such operations is impressive. According to the Russian Ministry for Economic Development, in 2001 up to 90 per cent of textiles, footwear and fur, and up to 70 per cent of perfume, was imported through 'grey import'. This reduces costs and still constitutes the basis of the lower prices at markets and in kiosks. The total volumes of 'shuttle' imports are comparable with the official trade turnover with some neighbouring countries. In 2000 the official Russian trade turnover with Turkey was about US $\$ 4$ billion, while 'shuttle' turnover was US\$3.5 billion. 'Shuttle' imports from Turkey exceeded the official imports by ten times. 'Shuttle' imports from China were three times greater than the official imports (Izvestia, 12 December 2001). So the implementation in 2002 of regulations that effectively equalize the customs duty for 'shuttle' and official importers should have a major impact on prices at the markets, and lead to a reduction in small retail trade.

On the city level, the administration started a campaign aimed at removing the new generation of kiosks and small retailers, and redeveloping the open air markets and trade zones as permanent facilities. According to official statistics, by 2002 the share of total retail turnover of markets and small retail trade in St Petersburg had fallen to 21 per cent (Sankt-Peterburgskie Vedomosti, 13 March 2002). By early 2002 in the Vasileostrovski district of the city, there were 193 food stores, 370 stores selling manufactured goods, 245 restaurants and cafes, 204 facilities providing personal services, one market hosting 266 traders, 7 trade complexes with a total of 800 traders, and trading zones where 694 registered small retailers operated (Delovoy Peterburg, 28 February 2002). These figures show the significance that the small retail trade still had for the retail trade and services sector in the city. The administration planned to act in two directions.

The first was to transfer as many small retailers as possible to the existing pavilions and trade complexes. Paradoxically enough, these plans seem to be as far removed from reality as their predecessors. The delegation of responsibility for regulating small retail from the city administration to the 110 newly elected municipal councils has led to a conflict of interest - the municipal councils were eager to maintain their budget receipts from small retail taxes and other contributions, whereas the city and district authorities wanted to reduce the number of small traders (Delovoy Peterburg, 28 February 2002).

The second more substantial effort was to redevelop the existing trade complexes, as well as developing new larger ones. In many cases, new complexes were to replace pavilions and trade zones on their sites. A large 
new trade complex appeared at Pr. Prosveschenia. It was announced that the pavilion complex, which replaced kiosks during the first stage of administrative restructuring, was to be replaced in turn by a new trade complex near Gorkovskaya metro station, in which the traders from the pavilions would be offered trading space to rent (Delovoy Peterburg, 5 March 2002). Similar processes took place all over the city. Figure 4.12 shows that by 2001, the development of large new trade complexes had started around almost all metro stations, which still remain a major attracting force for the retail trade.

The scale of such developments reflects the daily passenger volumes, as was the case with the earlier development of kiosk agglomerations. The northern metro line that leads from Nevski Pr. to Pr. Prosveschenia is the leader both in terms of passenger turnover and the pace of development of trade and services complexes. The neighbouring line from Lesnaya to Deviatkino represents the other extreme - a break in the middle of the line means that very few people now use the line, and almost no big retail outlets have appeared there.

'Kiosk chains' are another trade form that became a characteristic of the latest stage of development of the specific trade forms in St Petersburg. The regulations of 1996-98 left only a few trade specializations open to kiosks, dairy products and press articles being among them. Since then, large local manufacturers and retailers have, in fact, distributed this market segment among themselves, excluding the small retailers. In 2001, there were six big chains of such retailers consisting of 1,218 kiosks and pavilions. The most dynamic development was shown by a chain distributing the milk products of local manufacturers and the retail chain of the local ice cream and frozen food producer (Delovoy Peterburg, 26 March 2002). Their spatial policy is quite conventional - in addition to the traditional kiosk locations, they tend to locate close to the large densely populated residential areas.

We can conclude that the development of the specific transformation trade forms has passed through distinct stages, each differing in terms of the dominant trade forms and their spatial structures (Table 4.5).

The result of this development has been a set of specific trade forms that have shaped the unique landscape of the post-transformation city. This means, above all, that the development of conventional international trade forms, which constitutes the basis of the post-transformation stage, has to occur in a context that takes the specificity of the transformation heritage into account. These specific transformation trade forms in their present shape constitute real and effective spatial and business competitors for the incoming international and Russian retail capital. This will be subject to analysis in Chapter 7. Here we can state that the development of the specific trade forms that emerged during transformation is far from over. In our opinion, these forms will stay for as long as the 'kiosk type' of 


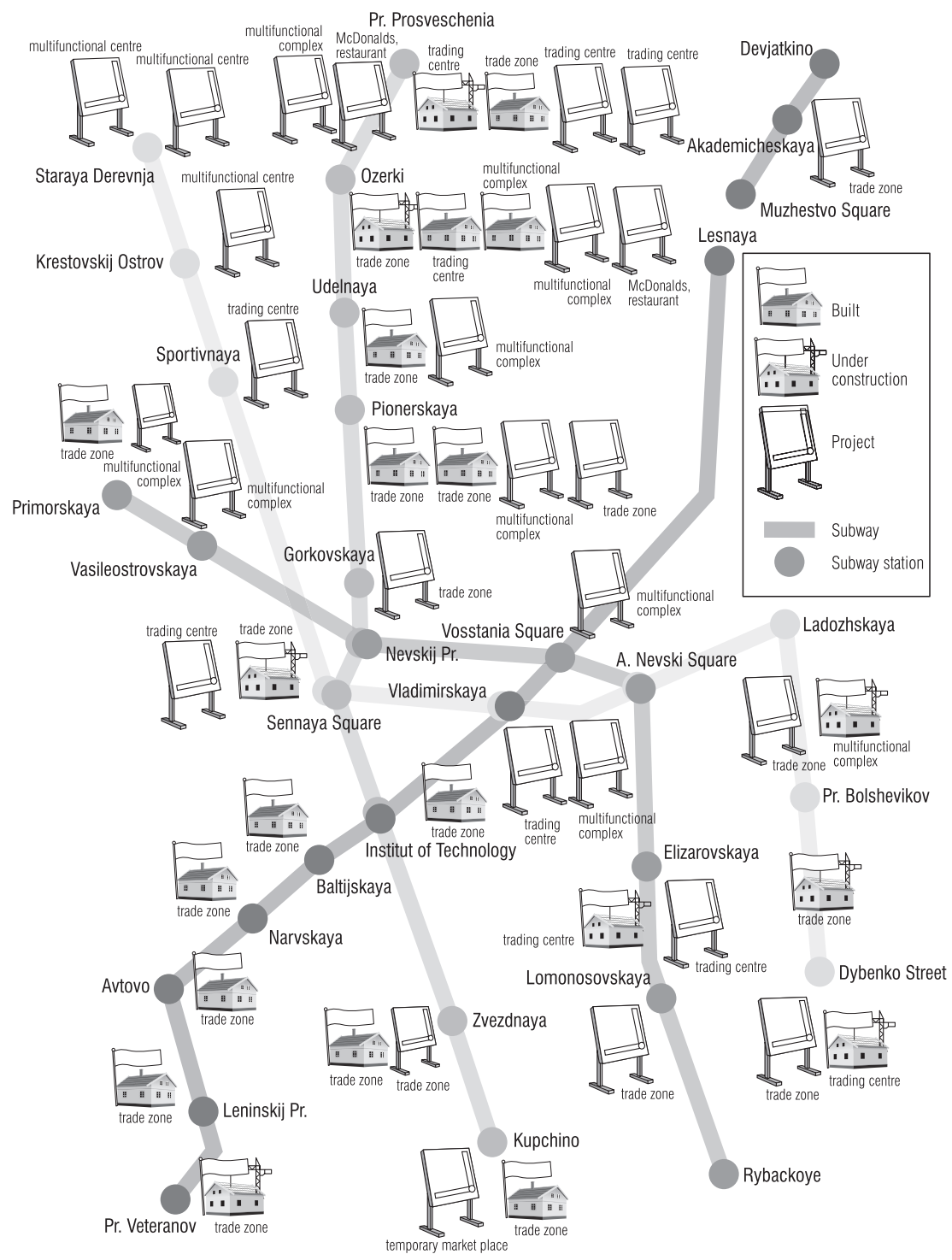

Figure 4.12 Development of large trade complexes around metro stations, 2001 Source: Reproduction from Delovoy Peterburg, 2 February 2001. 


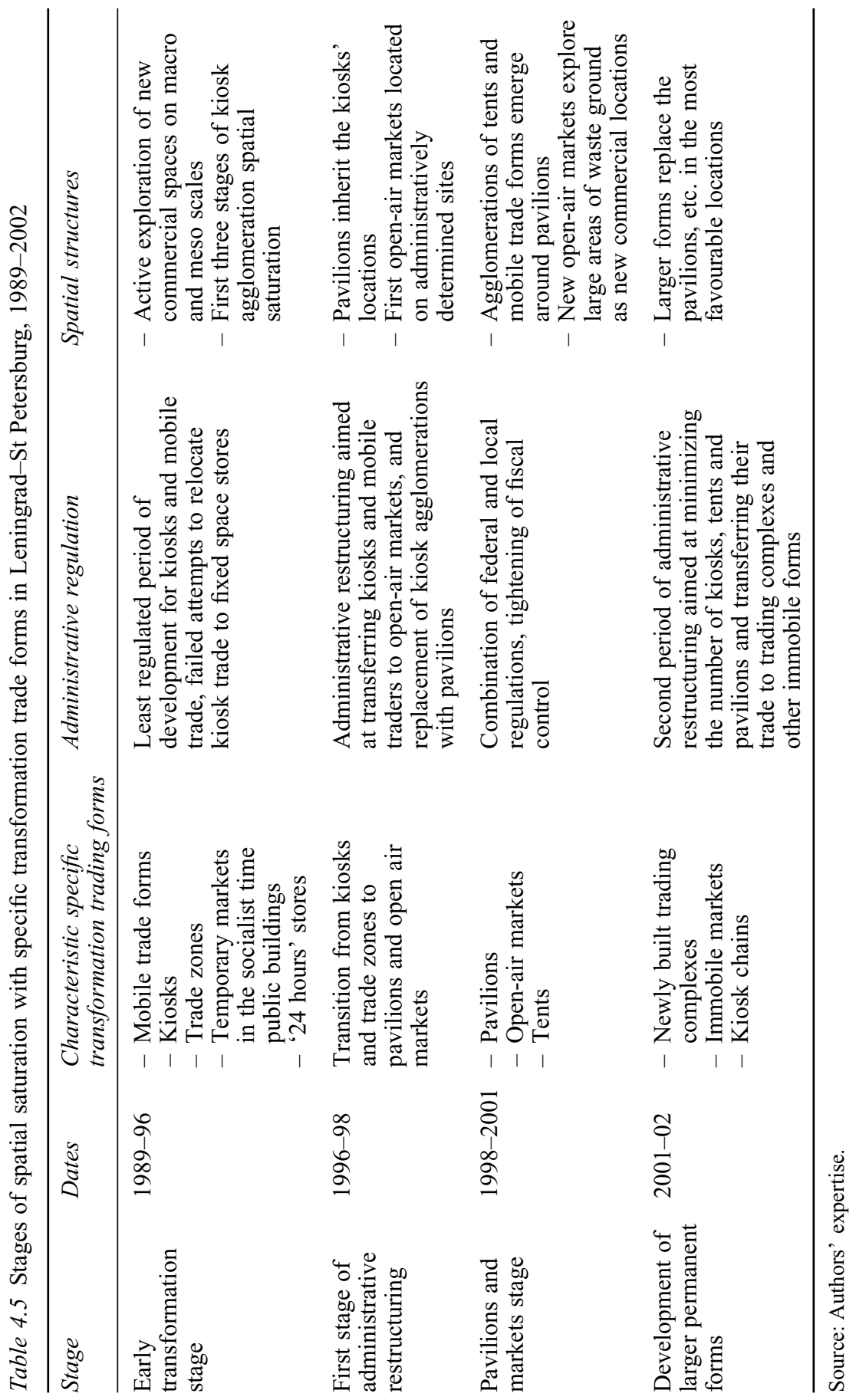




\section{Specific forms of spatial saturation}

shopping model continues to be the dominant one, and until general living standards improve. The last statement refers to the fact that small retail and markets trade forms respond to the minimal demands of both traders and their customers. For both categories this smallest trade is still the means of economic survival. 


\section{The spatial transformation of vertical business structures}

The previous chapter was concerned with the development of the trade forms, which we consider to be a specific feature of the transformation period; this chapter discusses the processes affecting the network of regular fixed-space stores occurring at the same time. As the results of the survey mentioned in the previous chapter show (Figure 4.2, p. 80), while about half of all purchases in St Petersburg in 1997 were made from kiosks and small retailers, in about 40 per cent of cases merchandise was bought through regular fixed-space stores. The lack of trading space in the fixed stores was one of the problems resolved in the early years of transformation by the introduction of kiosks and small retail forms. So, by charting the development of the network of fixed-space facilities in St Petersburg during the transformation period we can observe how the city became spatially saturated with this type of retail and services facilities. It is on this process that we focus in this chapter. In doing so, we draw on findings and analysis from our previous publications, which have been updated to cover the period to 2002 and rethought in the context of our present research (Axenov, Brade and Bondarchuk, 1997; Axenov, 2001).

As outlined before, we distinguish between two distinct forms taken by spatial saturation - the spatial transformation of vertical business structures and territorial complex building. In this chapter, we analyse the first form, the spatial transformation of vertical business structures. We have described in previous chapters the processes that bring primary business units together as branches of trade or vertical business structures. The spatial transformation of vertical business structures refers to the development of the principles of location (and the results of their implementation) for specific branches of the retail trade and services sector and their facilities.

\section{The changing structure of the retail trade and services sector 1989-2002 ${ }^{1}$}

The changes that took place in the structure of the retail trade and services sector during this time allow us to divide the post-socialist development 


\section{Vertical business structures}

of this sector into at least two distinct periods. The first can be referred to as the transformation period of development, and the second as the post-transformation period of development. ${ }^{2}$ Table 5.1 shows the number of facilities belonging to 53 selected branches of the retail trade and services sector in Leningrad-St Petersburg at three different points in time: 1988, the last year of socialist development; 1996, during the transformation period; and 2002, the most recent period of development. What enables us to claim that differences in business structure could be attributed to the principally different development stages?

In the period between 1988 and 1996, the overall number of business establishments in the retail trade and services sector quadrupled, and in more than 50 branches of retail trade and services the number of facilities

Table 5.1 Changes in the structure of the retail and services sector, 1988, 1996, $2002^{\mathrm{a}}$

\begin{tabular}{|c|c|c|c|c|}
\hline & \multirow{2}{*}{$\begin{array}{l}\text { Branch name } \\
\text { Trade }\end{array}$} & \multicolumn{3}{|c|}{ No. of objects } \\
\hline & & 1988 & 1996 & 2002 \\
\hline 1 & Office equipment & 0 & 200 & 180 \\
\hline 2 & Automobile & 5 & 200 & 210 \\
\hline 3 & Construction goods & 30 & 400 & 450 \\
\hline 4 & Car parts and accessories & 15 & 190 & 400 \\
\hline 5 & Furniture & 25 & 300 & 640 \\
\hline 6 & Audio, video, electronics & 30 & 315 & 680 \\
\hline 7 & Wholesale trade & 50 & 460 & $\mathrm{~N} / \mathrm{a}$ \\
\hline 8 & Jewellery & 15 & 80 & 160 \\
\hline 9 & Consumer goods retail trade & 150 & 750 & 160 \\
\hline 10 & Textile & 25 & 95 & 200 \\
\hline 11 & Household goods & 80 & 255 & 280 \\
\hline 12 & Footwear & 70 & 210 & 220 \\
\hline 13 & Food & 1,350 & 2,660 & 1,720 \\
\hline 14 & Stationery & 80 & 150 & 400 \\
\hline 15 & Haberdashery & 60 & 80 & 70 \\
\hline 16 & Perfume and cosmetics & 120 & 130 & 210 \\
\hline 17 & Tourist companies and travel agents & 3 & 600 & 680 \\
\hline 18 & Auditing, consulting, marketing & 0 & 190 & 340 \\
\hline 19 & Advertising agencies & 0 & 180 & 350 \\
\hline 20 & Banks: affiliates $^{\mathrm{b}}$ & 0 & 170 & 150 \\
\hline 21 & Design, stylists & 0 & 120 & 280 \\
\hline 22 & Security & 1 & 80 & 390 \\
\hline 23 & Railway transport & 1 & 60 & 130 \\
\hline 24 & Casinos, night clubs & 0 & 55 & 150 \\
\hline 25 & Computer hardware and software & 10 & 490 & 600 \\
\hline 26 & Banks: central offices & 4 & 130 & 110 \\
\hline 27 & Investment and financial services & 10 & 290 & 100 \\
\hline 28 & Air transport & 2 & 50 & 40 \\
\hline 29 & Notaries public & 20 & 475 & 270 \\
\hline 30 & Real estate & 15 & 350 & 450 \\
\hline 31 & Telecommunications & 10 & 215 & 180 \\
\hline
\end{tabular}


increased at least twice over. No fewer than a dozen new branches emerged, which did not exist at all or were monopolized in socialist times. Three groups of branches represented definite 'boom' areas on the city level, each reflecting certain macro-trends in the economy. The first group was wholesale trade and the transport industries, which reflected the overall growth in consumption-oriented activity and the related flourishing of the retail trade and infrastructure. The second group was linked to the construction 'boom' and included the construction industry itself, the related infrastructure as well as related branches of trade, such as construction goods and furniture. The composition of the third group of 'boom' branches reflected efforts within the St Petersburg economy to bring the city into the information age. This process is indicated by the very high levels of activity by

Table 5.1 (cont.)

\begin{tabular}{|c|c|c|c|c|}
\hline & \multirow{2}{*}{$\begin{array}{l}\text { Branch name } \\
\text { Trade }\end{array}$} & \multicolumn{3}{|c|}{ No. of objects } \\
\hline & & 1988 & 1996 & 2002 \\
\hline 32 & Automobile servicing & 15 & 295 & 630 \\
\hline 33 & Legal services & 20 & 300 & 540 \\
\hline 34 & Paper supply & 10 & 110 & 250 \\
\hline 35 & Insurance & 20 & 200 & 300 \\
\hline 36 & Printing and copying & 50 & 420 & 450 \\
\hline 37 & $\begin{array}{l}\text { Construction goods: wholesale and } \\
\text { services }\end{array}$ & 30 & 230 & 210 \\
\hline 38 & Educational courses & 30 & 220 & 260 \\
\hline 39 & $\begin{array}{l}\text { Electronic mass media and film } \\
\text { companies }\end{array}$ & 15 & 105 & 100 \\
\hline 40 & Good quality restaurants & 50 & 285 & 300 \\
\hline 41 & $\begin{array}{l}\text { Fast food and lower quality self- } \\
\text { service restaurants }\end{array}$ & 50 & 260 & 180 \\
\hline 42 & Hotels & 30 & 140 & 135 \\
\hline 43 & Printing & 70 & 270 & 290 \\
\hline 44 & Construction services & 100 & 370 & 290 \\
\hline 45 & Publishing & 60 & 200 & 390 \\
\hline 46 & Cafes, bars & 250 & 740 & 690 \\
\hline 47 & Medical services & 200 & 570 & 600 \\
\hline 48 & Hairdressing, cosmetics & 150 & 360 & 420 \\
\hline 49 & Cargo shipment & 100 & 225 & 310 \\
\hline 50 & Open-air overnight car parking & 100 & 215 & 360 \\
\hline 51 & Self service cafes & 170 & 300 & $\mathrm{n} / \mathrm{a}$ \\
\hline 52 & Repairing, laundry, dry cleaning & 470 & 385 & $\mathrm{n} / \mathrm{a}$ \\
\hline \multirow[t]{2}{*}{53} & Dressmaking and tailoring & 250 & 200 & $\mathrm{n} / \mathrm{a}$ \\
\hline & Total & 4,421 & 16,330 & 16,905 \\
\hline
\end{tabular}

Source: Calculated on the basis of telephone directories 1988, 1996, 2002.

Notes:

a All figures in this table are rounded.

b Excluding Sberbank - former socialist monopolist.

$\mathrm{n} / \mathrm{a}-$ not listed in the telephone directories. 
computer, telecommunications, information, advertising and printing companies at that time. At the same time, some of the service branches typical of the socialist era, such as ordinary dressmaking, repair services, laundry services and dry cleaning, declined.

Quite different processes were demonstrated between 1996 and 2002. The overall number of establishments generally stabilized, although in certain branches substantial reductions could be observed. In about half of the branches listed in Table 5.1, the number of facilities has either remained more or less the same, or even declined in this period. This reduction (stabilization) of the number of facilities can be attributed, in the main, to three factors. The first is the saturation of consumer demand for certain goods and services, and the related tightening of competition within branches. This might be the case in certain branches of trade, such as footwear, household goods, haberdashery and, to a certain extent, food stores. Some services can be included in this list too - e.g. restaurants, banking, notaries, etc. The second factor is the evaporation of, or substantial reduction in the demand for, some services. This might be the case with traditional personal and household services such as tailoring, repairing, laundering, etc., as well as with small universal consumer goods stores. In the latter case this is due to the growing specialization of small shops and the shift of the universal trade to the big department stores, hypermarkets, etc. Hence third, the stabilization or reduction in the number of facilities is due, in some cases, to the process of spatial concentration - bigger trade forms appear, forcing smaller competitors out of the market.

Analysis of the branches experiencing quantitative growth during this second period is even more insightful. In more than 15 branches the number of facilities increased by more than 50 per cent. From Table 5.1 two major trends can be discerned: on the one hand, the rapid growth in the business services (including some branches of trade such as stationery), which is an obvious reflection of the general modernization trend with its distinct signs of post-industrial development; and on the other hand, the rapid growth of the branches serving car owners. This trend is a direct result of the general increase in car ownership rate in St Petersburg, which in turn has inevitably influenced the general transportation pattern and related shopping model in the city.

Furthermore, during this period at least, one of the boom areas of the previous period has stabilized. Construction-related demand is now generally satisfied by the existing level of facilities, both in trade and services. This is consistent with the slowdown in the growth of personal construction activities and the increased use of professional contractors, as well as with the concentration that has taken place within construction-related trade and services. More importantly, the last period has seen the general saturation of consumer demand for facilities in some basic branches of trade and personal services, and the main areas of major quantitative growth trend are now the business services. 
All the features listed above, indicate the basic differences between the structure of business in the socialist, transformation and post-transformation periods.

\section{Spatial saturation and vertical business structures}

The main mechanism for spatial saturation with vertical business structures took the form of the spatial division of the market between different branches of trade and services. We consider this process to be more important than competition between individual retailers and service providers for better location within a branch. Retail trade and services branches with different specializations look for different types of urban environment.

The location market that existed in St Petersburg during most of the transformation period operated under free conditions, which means that by studying the real distribution of different retail and service facilities, we can conditionally describe the general territorial requirements and preferences of different branches of the retail trade and services sector during this time. On the basis of 34 original maps of the distribution of various retail trade and services branches for 1996 and 2002 respectively, we tried to distinguish differences in their locational priorities and to interpret these observations in terms of the factors most likely to have resulted in such a distribution. Our expertise enabled us to define eleven major locational preferences that were observed in the distribution of different branches in the city. ${ }^{3}$ These preferences are listed below, along with possible explanations of their origin:

1 Centrality: most of the facilities of those branches with a preference for centrality are rather evenly distributed within the historical centre of the city, and only 20-30 per cent of them are located in the other parts. As a rule, these companies are of the office type and do not have any locational requirements except accessibility, proximity to administrative authorities and infrastructural institutions, and prestige, all of which calls for a central location.

2 Conditional centrality: as in the previous case, most of the units of these branches are located within the city centre, but not evenly, since they have one or several distinct local zones of concentration. This might be the result of historical coincidence or of territorial cooperation. Some branches tend to exploit the public function of the centre and use their prestigious location on the main streets, oriented to the traffic and pedestrian flows, as a means of marking their presence.

3 Central periphery: such branches tend to be concentrated in the periphery of the historical centre of the city. This preference might be due to the need for more space and greater accessibility for trucks, but it might also be the result of territorial competition with other branches for centrality. 
4 Ribbons: objects are located near the major motorways. The reason supposed for this is the desire for publicity and the assumption that customers are concentrated among drivers.

5 Dispersed: these branches are relatively evenly distributed throughout the city - it is hard to distinguish any concentration. There may be several reasons for this pattern - orientation to the local markets, various limitations and regulations applying to locations in the historical centre.

6 Consumer markets: the majority of the facilities of branches with this locational priority are normally proportionally distributed in residential zones, according to their permanent population size. These are branches providing consumer goods and services of constant or random demand for local markets.

7 Industrial zones: most of the establishments of such a branch are located within industrial or non-residential areas. This could be due to the technical requirements for space, infrastructure, etc. or administrative restrictions on the location of this branch in residential zones.

8 Fringes of the major residential or industrial zones attract those branches that need large amounts of low-cost space. Some may be oriented towards adjoining residential areas; others may just be seeking cheap land as close as possible to the centre or communication axes.

9 Territorial cooperation: the existence of functional areas of interrelated business activities.

10 Joint territorial attraction: concentration of the facilities of the same or similar business types in close vicinity to each other. This concentration gives an additional attraction to the location as a whole, but at the same time increases competition within this location. Normally, it is possible to identify the prime source of attraction in such clusters.

11 Customer concentration: some of the facilities of such branches are located in close proximity to points of potential customer concentration, such as transport nodes, etc.

Table 5.2 shows the locational preferences that we have determined, on the basis of our interpretation of the maps, to be characteristic for each of the 34 branches. Each branch was allocated up to four major preferences. The figures from ' 1 ' to ' 4 ' in the table correspond to the relative rank of the preference: with ' 1 ' denoting the preference/factor of prime importance for the branch, '2' the second placed preference/factor and so on.

Most of the branches preserved the major features of their locational patterns between 1996 and 2002. The changes and processes that took place in certain cases will be discussed later in this chapter.

We have identified five types of spatial preference that differ between branches (see p. 114). 
Table 5.2 Major locational preferences for the retail and services branches in St Petersburg, 1996-2002

\begin{tabular}{|c|c|c|c|c|c|c|c|c|c|c|c|c|c|}
\hline \multirow[t]{2}{*}{ No. } & \multirow[t]{2}{*}{ Branch } & \multicolumn{11}{|c|}{ Priorities } & \multirow[t]{2}{*}{ Type } \\
\hline & & 1 & 2 & 3 & 4 & 5 & 6 & 7 & 8 & 9 & 10 & 11 & \\
\hline 1 & $\begin{array}{l}\text { Investment and } \\
\text { financial services }\end{array}$ & 1 & & & & & & & & & & & 1 \\
\hline 2 & Casinos, night clubs & 1 & & & & & & & & & & & 1 \\
\hline 3 & $\begin{array}{l}\text { Fast food and lower- } \\
\text { quality self-service } \\
\text { restaurants }\end{array}$ & 1 & & & & & & & & & & & 1 \\
\hline 4 & Good-quality restaurants & & 1 & & & & & & & & & & 1 \\
\hline 5 & Publishing & 1 & & & & & & & & & & & 1 \\
\hline 6 & Advertising agencies & & 1 & & & & & & & & & & 1 \\
\hline 7 & $\begin{array}{l}\text { Electronic mass media } \\
\text { and film companies }\end{array}$ & & 1 & & & & & & & & & & 1 \\
\hline 8 & Telecommunications & & 1 & & & & & & & & & & 1 \\
\hline 9 & Office equipment trade & 1 & & & & & & & & 2 & & & 1 \\
\hline 10 & $\begin{array}{l}\text { Tourist companies and } \\
\text { travel agents }\end{array}$ & 1 & & & & & & & & 2 & 3 & & 1 \\
\hline 11 & Banks: central offices & & 1 & & & & & & & & & & 1 \\
\hline 12 & Real estate & & 1 & & & & & & & & & & 1 \\
\hline 13 & Printing & & 1 & & & & & & & & & & 1 \\
\hline 14 & $\begin{array}{l}\text { Computer hardware and } \\
\text { software }\end{array}$ & & 1 & & & & & & & & 2 & & 1 \\
\hline 15 & Wholesale trade & & & 1 & & & & & & & & & 1 \\
\hline 16 & $\begin{array}{l}\text { Prestigious brand name } \\
\text { shops }\end{array}$ & & 1 & & 2 & & & & & & & & 1 \\
\hline 17 & Insurance & & 1 & & & & & & & & & & 1 \\
\hline 18 & Cafes, bars & 1 & & & & & 2 & & & & & & 2 \\
\hline 19 & Furniture trade & & & 1 & & & 2 & & & & & & 2 \\
\hline 20 & Construction goods trade & & & 1 & & & 2 & 3 & & & & & 2 \\
\hline 21 & Household goods trade & & 1 & & & & 2 & 4 & & & 3 & & 2 \\
\hline 22 & Legal services & & 1 & & & & 3 & & & & 2 & & 2 \\
\hline 23 & Notary's offices & 1 & & & & & 2 & & & 4 & 3 & & 2 \\
\hline 24 & Audio, video, electronics & & 1 & & 2 & & 3 & & & & 4 & & 2 \\
\hline 25 & Banks: affiliates & 1 & & & & & 2 & & & & & & 2 \\
\hline 26 & $\begin{array}{l}\text { Consumer goods retail } \\
\text { trade }\end{array}$ & & 1 & & 3 & & 2 & & & & & & 2 \\
\hline 27 & Currency exchange & 2 & & & & & 3 & & & & & 1 & 2 \\
\hline 28 & Food stores & & & & & 2 & 1 & & & & & & 3 \\
\hline 29 & $\begin{array}{l}\text { Open-air overnight } \\
\text { car parking }\end{array}$ & & & & & 1 & 2 & & 3 & & & & 3 \\
\hline 30 & Automobile trade & & & & & 1 & & & 2 & & & & 4 \\
\hline 31 & Hotels & & & & & 1 & & & & & & & 4 \\
\hline 32 & Security & & & & & 1 & & & & & & & 4 \\
\hline 33 & Cargo shipment & & & & & 1 & & 2 & & & & & 5 \\
\hline 34 & Automobile servicing & & & & 3 & 1 & & 2 & & & & & 5 \\
\hline
\end{tabular}

Source: Axenov, Brade and Bondarchuk, 1997. 


\section{Vertical business structures}

Type 1 The tendency towards 'centrality', when facilities of a particular branch tend to concentrate almost exclusively in the city centre.

Type 2 The tendency towards 'centrality and locality', when facilities gravitate towards both a central position and/or towards local consumer markets in the most densely populated areas outside the centre.

Type 3 The tendency towards 'locality' - branches tend to locate according to the population density patterns, i.e. closer to the major consumer markets.

Type 4 'Dispersed' with no clear locational preference.

Type 5 The tendency towards 'industrial zones'.

Some of these spatial preferences result from the specific spatial distribution patterns of the branch clientele, such as regular food stores that follow residential density patterns and compete for location almost exclusively with establishments of the same branch. Some branches look for specific technically prescribed spatial requirements, such as cargo shipment, which needs rather large, specially equipped sites and thus is based mostly in the industrial zones. Other preferences represent the result of spatial competition for the same type of clientele between branches. For example, the construction goods or furniture trade are concentrated in locations on the fringes of the city centre. These establishments, like those of all other branches in the centre, aim to attract a city-wide clientele. But, their business, which requires rather a large amount of floor space, cannot compete with banking, computer and telecommunication services and other more profitable usages for a more central location. The inclusion of market forces in this locational process allows us to speak of a spatial division of the market.

The types of spatial preference outlined above indicate the existence of at least five locational markets, in which branches compete, and which differ in terms of the priorities that drive this spatial competition. For further analysis we have selected 19 branches that we consider to be representative of each type of locational preference (see Table 5.3).

These markets also differ in terms of the intensity of the spatial competition between branches. There is no doubt that the market for the locations favoured by the 'centrality oriented' branches is the most competitive one. The high intensity of the competition between the branches of this type is due to the fact that very few of them have any locational priorities other than centrality. While the branches of the second type have only to compete with very few exclusively locality oriented branches of the third type and with each other for places in the local consumer markets, in the centre of the city they face numerous purely 'centrality oriented' branches. Few branches tend to look for space in the old industrial belt that encircles the historical centre of the city, and separates it from the areas of socialist housing, making this the arena for the least tense spatial 
Table 5.3 Distribution of 19 selected branches and their facilities by the type of locational preference, 1996-2002

\begin{tabular}{|c|c|c|c|c|}
\hline \multirow[t]{2}{*}{ Type of locational preference } & \multirow{2}{*}{$\begin{array}{l}\text { No. of } \\
\text { selected } \\
\text { branches }\end{array}$} & \multicolumn{2}{|c|}{$\%$ of all facilities } & \multirow{2}{*}{$\begin{array}{l}\text { Change, } \\
1996- \\
2002\end{array}$} \\
\hline & & 1996 & 2002 & \\
\hline Centrality oriented & 9 & 34.3 & 47.8 & 13.5 \\
\hline $\begin{array}{l}\text { Centrality and locality } \\
\text { oriented }\end{array}$ & 5 & 26.6 & 26.0 & -0.6 \\
\hline Locality oriented & 1 & 28.9 & 17.3 & -11.6 \\
\hline Dispersed & 2 & 3.0 & 2.4 & -0.6 \\
\hline Industrial zones oriented & 2 & 7.2 & 6.5 & -0.7 \\
\hline
\end{tabular}

competition. The share of all facilities in the centrality oriented branches increased significantly between 1996 and 2002, which makes their locational market even more competitive. The share of the locality oriented branches dropped. This might mean that the locality market has reached saturation, while centrality oriented branches provide goods and services that are still subject to growing demand.

\section{Urban morphology and the distribution of retail trade and services}

The comparison of the extent and intensity of the locational preferences listed above shows that the geographical system of retail trade and services is heavily dependent on two major spatial factors. A combination of these two factors explains most of the zonal and sectoral differences in the distribution of the various types of business.

The first factor could be termed 'urban morphology', under which we subsume general features of population, economic geography and land use. With minor exceptions, urban morphology divides the city into three major concentric zones, each having a different attraction for business:

1 historical centre of the city; ${ }^{4}$

2 inner industrial belt primarily of the eighteenth to the early twentieth centuries, which encircles the centre of the city and separates it from the socialist era residential areas;

3 socialist era residential areas built in 1920-1990s.

Figure 5.1 maps the location of the main morphological zones in the city. We consider that this particular zonal division constitutes a major shaping influence on the formation of the spatial system of retail trade and services in St Petersburg. The attractiveness of these zones for retail and service activities changed significantly between 1988, 1996 and 2002 (see Table 5.4). 


\section{Vertical business structures}

It is obvious that the introduction of market forces as the main determinant of business location has changed the zonal location pattern dramatically. The major principle followed by socialist planners in the distribution of retail and services facilities was based on the idea of 'spatial hierarchy' - services of random demand were placed in the city centre, of periodical demand in each region, and of everyday demand within walking distance of each household. The number of facilities necessary was determined according to state approved consumption norms proportional to the density of the population.

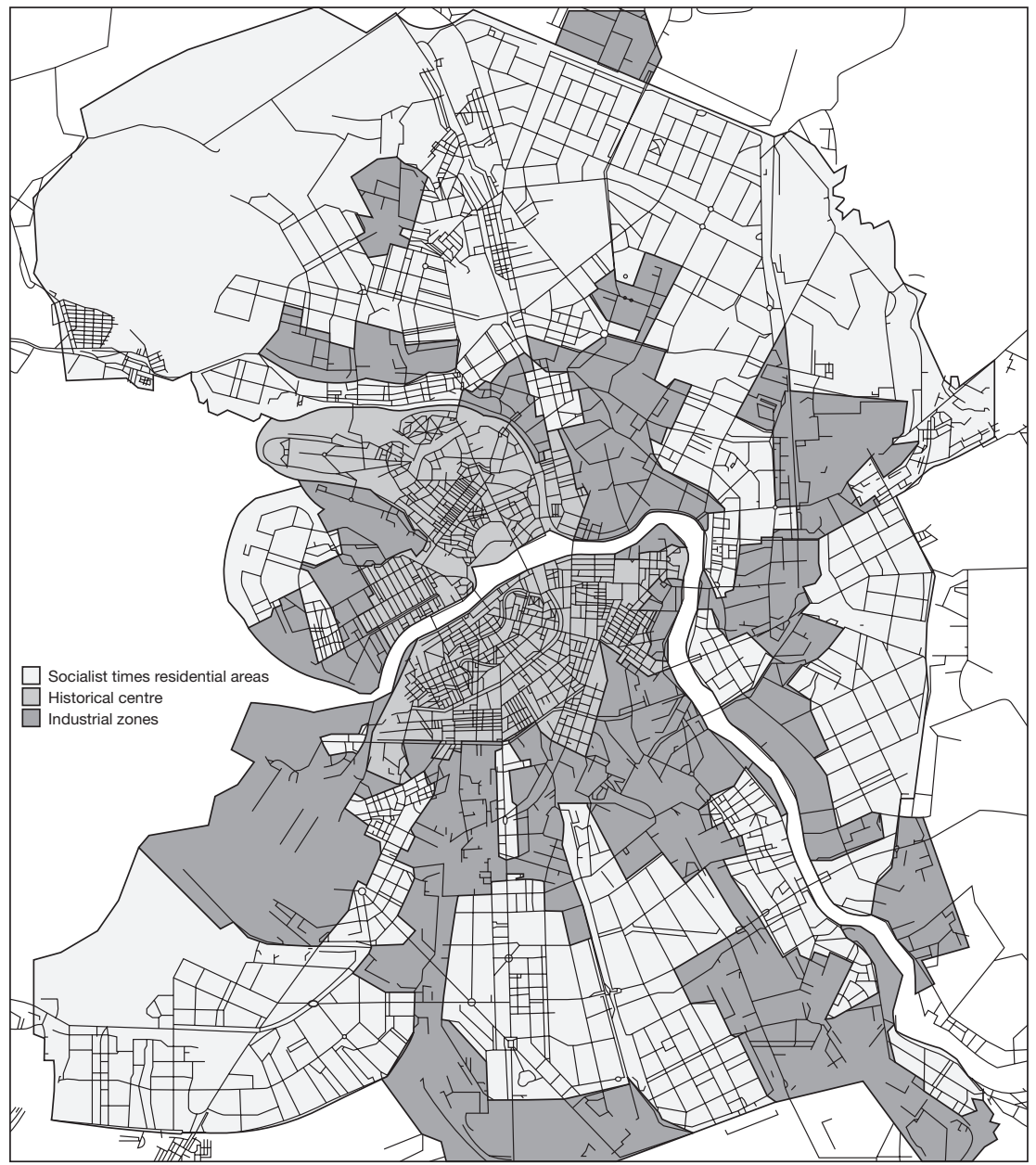

Figure 5.1 Functional zones of St Petersburg 
Table 5.4 Changing significance of the city's morphological zones for the retail and services business, 1988, 1996, 2002

\begin{tabular}{lccccc}
\hline $\begin{array}{l}\text { Morphological } \\
\text { zone }\end{array}$ & $\begin{array}{l}\text { \% of the } \\
\text { facilities, } \\
1988\end{array}$ & $\begin{array}{l}\text { \% of the } \\
\text { facilities, } \\
1996\end{array}$ & $\begin{array}{l}\text { Difference } \\
1988- \\
1996\end{array}$ & $\begin{array}{l}\text { \% of the } \\
\text { facilities, } \\
2002\end{array}$ & $\begin{array}{l}\text { Difference } \\
1996- \\
2002\end{array}$ \\
\hline $\begin{array}{l}\text { Historical centre } \\
\text { of the city }\end{array}$ & 44.4 & 51.6 & 7.2 & 47.4 & -4.2 \\
$\begin{array}{l}\text { Industrial zones } \\
\begin{array}{l}\text { Socialist era } \\
\text { residential areas }\end{array}\end{array}$ & 77.2 & 13.4 & 6.2 & 20.6 & 7.2 \\
\begin{tabular}{l} 
Other areas \\
\hline
\end{tabular} & 0.6 & 0.9 & 0.3 & 5.0 & 4.1 \\
\hline
\end{tabular}

Source: Authors' expertise.

Note: Calculations were made on the basis of estimates of the total number of facilities from all surveyed branches in each of the city's 9,500 land use units or quarters.

Rapid changes in the structure of the business, diversification of the clientele, demand and consumption habits and other market-related reasons contributed to the changes in the relative attractiveness of the zones between 1988 and 1996. First of all, if in socialist times the greatest share of facilities were to be found in the residential areas, where majority of the population lived, under market conditions the absolute majority of facilities started to concentrate in the city centre. Although the actual number of retail and services facilities in residential areas almost doubled during this period, the relative share of such facilities in residential areas declined dramatically.

The highest pace of growth in retailing and services during the first stage of transformation took place in the city centre and in the industrial belt. In case of the city centre, this increase was due to the very high level of spatial competition in the 'centrality oriented' locational market - an absolute majority of branches tended to seek a city-wide clientele and publicity. The extent of retail and services growth in the 'rust belt' - the most problematic area of the city - between 1988 and 1996 is explained by the general underdevelopment of retail trade and services in this area during socialist times, and the availability of a vast amount of cheap and accessible space after the collapse of the socialist economy.

Distinctly different trends characterize the period between 1996 and 2002. New business locations were developing in two zones at that time - the industrial zone and 'other' areas. The share of retail and services facilities located in the city centre declined, although it still remained the largest share. The largest relative loss (although not as large as during the early transformation period) was again experienced by the socialist era residential areas. How can these trends be explained? 


\section{8}

The reduction in the city centre's share of facilities overall was accompanied by an increase in the share of the 'centrality oriented' branches in the city centre, and the tightening of the competition for this location in the period 1996-2002 (see Tables 5.2 and 5.3). At the same time, while the share of facilities belonging to industrial zones oriented branches declined somewhat, the industrial zone itself experienced a rise in the share of facilities (of all branches) located there. These two trends lead us to a number of assumptions. The city centre has been under continual pressure from incoming retail trade and service facilities for more than 10 years; it seems logical that the best business locations there have already been occupied. The newly emerging 'centrality oriented' branches and facilities are probably starting to explore new locational possibilities outside the highly competitive centre. The inner industrial belt that surrounds the historical centre offers them the most accessible opportunities. Our further analysis provides some evidence that the increased share of facilities in the industrial zone was not the result of growth in the retail and services branches traditionally oriented towards industrial zones, but rather the expansion of the 'centrality' and 'centrality and locality' oriented branches.

Another trend for the period 1996-2002 is the exploration of new locations in morphological surroundings, which had not previously been the scene of retail trade and services development. In Table 5.4 the term 'other areas' includes 'green' areas - parks and forests, as well as farmland, rural housing, roads and other infrastructural facilities and their fringes, etc. The increase in the share of the facilities located in these 'other areas' may reflect a general trend of seeking new types of location all over the city, including its outskirts. This trend is discussed at greater length in other chapters. Socialist era residential areas remained the least desirable zone for the new developmental trends.

Figures 5.2 to 5.5 show the patterns of spatial distribution for different retail and service facilities according to their type of locational preference. The figures depict the spatial patterns of distribution for the branches most characteristic of the five types outlined (see p. 114). The locations of facilities from 1996 and 2002, as well as the major morphological zones are shown.

The distribution of tourism companies (Figure 5.2) demonstrates the most common spatial pattern of 'centrality' and 'centrality and locality' oriented branches. The primary zone of concentration hosting the absolute majority of facilities both in 1996 and 2002 was the city centre. Ribbonshaped secondary concentrations were associated with major transportation routes, and had, in some cases, a density of facilities close to that of the centre. Outside these ribbons, both the industrial zones and residential areas were almost devoid of tourism companies, even losing by 2002 those few facilities that had existed in 1996. 


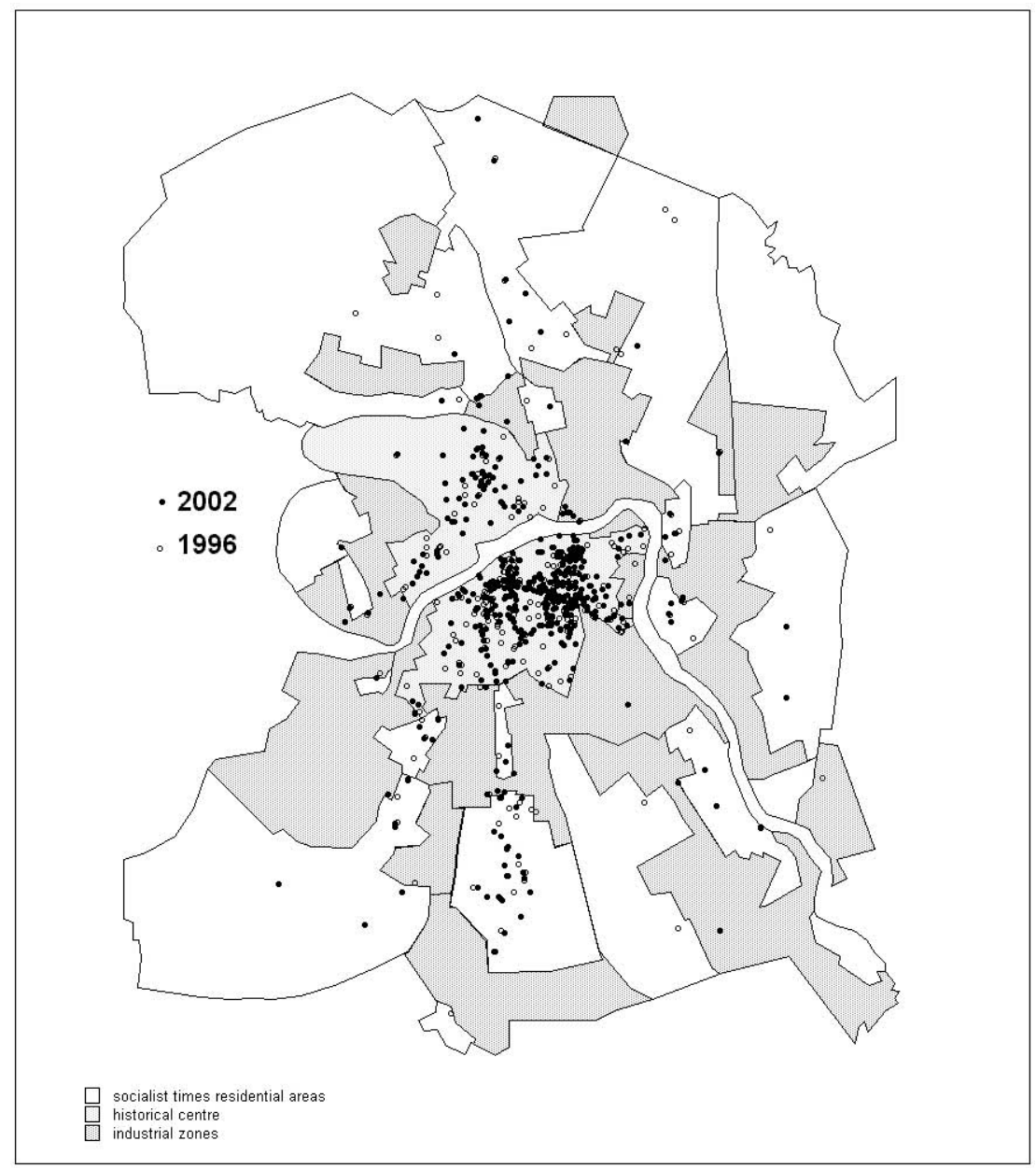

Figure 5.2 Tourism companies distribution by functional zones of St Petersburg, 1996-2002

Source: Calculated on the basis of telephone directories 1996, 2002.

The distribution of food stores (Figure 5.3) is typical of the classical 'locality' oriented branch. In general, the distribution of such facilities followed the population distribution pattern, tending to serve the everyday demand for food stuffs. A certain concentration of food stores could be found in the city centre reflecting two major factors. First, the morphological structure of the historical city quarters meant that they tended to host primarily smaller shops, while in other morphological zones larger facilities, such as supermarkets, were more common. Second, as well as 


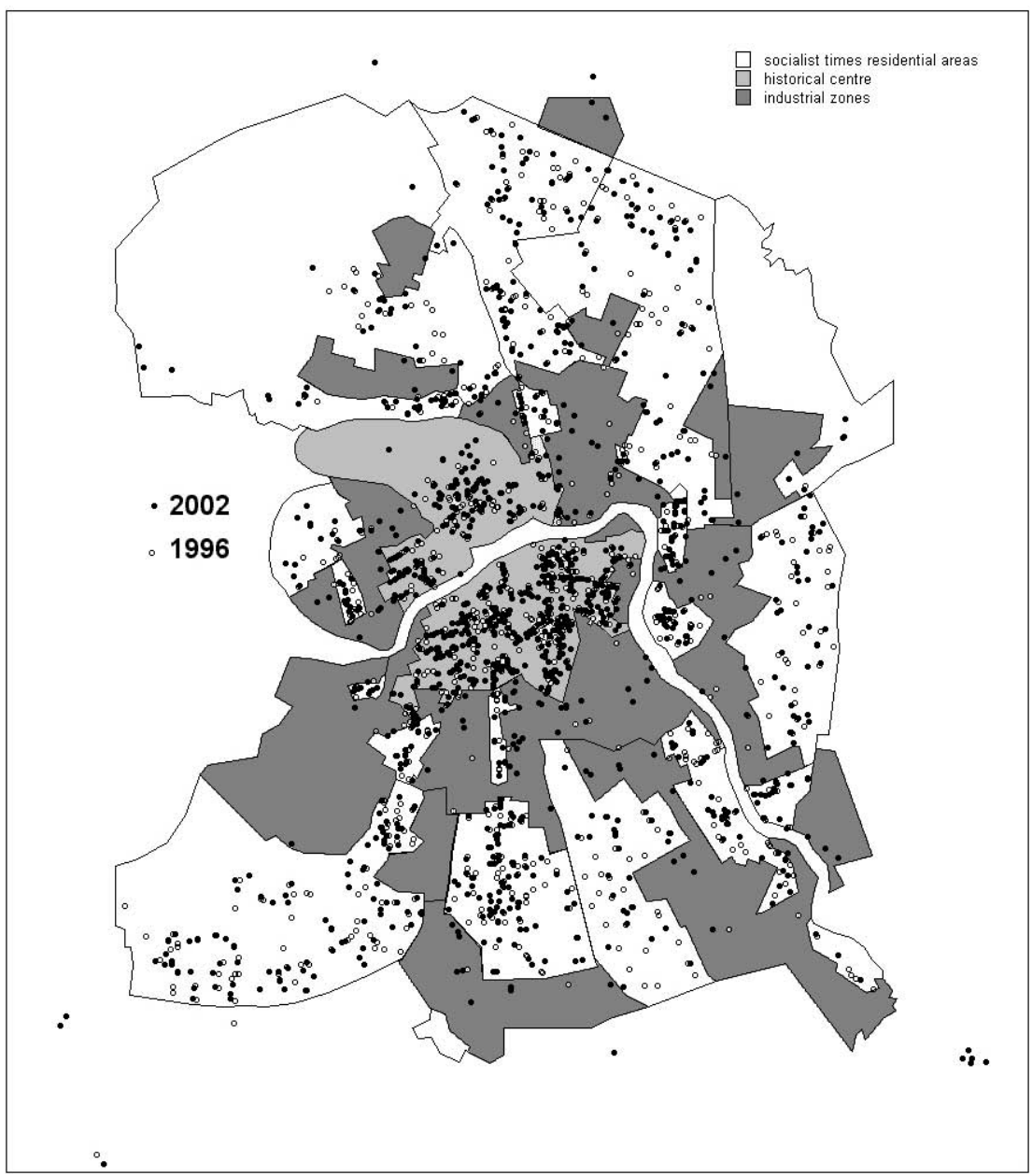

Figure 5.3 Food stores distribution by functional zones of St Petersburg, 1996-2002

Source: Calculated on the basis of telephone directories 1996, 2002.

serving the permanent population of the city centre, food stores there tended to perform a city-wide specialization. This specialization could be based either on providing a specialized merchandise or just a higher-quality service. In certain parts of the socialist era residential areas, a tendency for food stores to concentrate along major transportation routes or in other more favourable locations could be observed between 1996 and 2002. Partly, this is a result of a transition to larger trade forms - small shops are being replaced by supermarkets. 


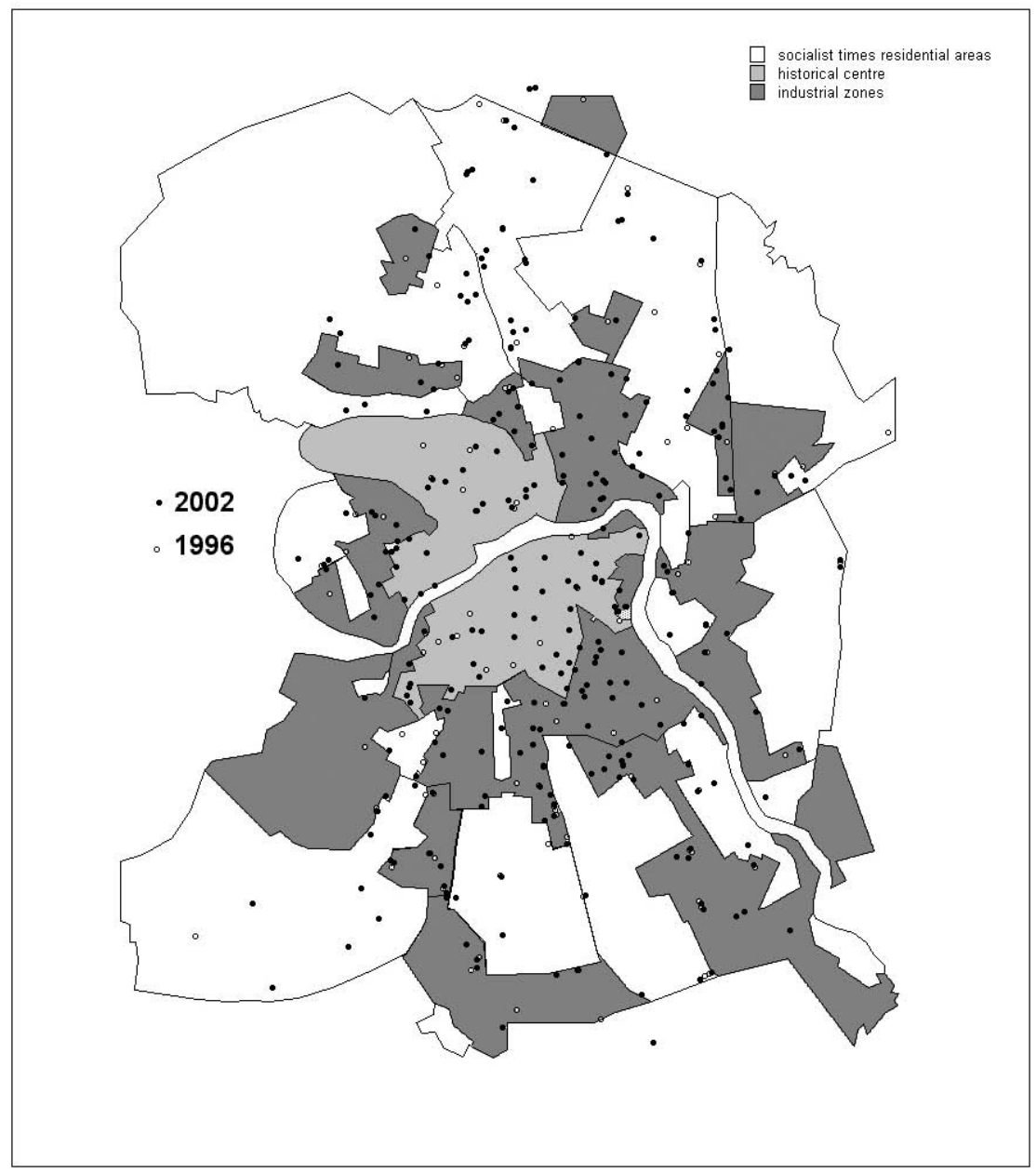

Figure 5.4 Automobile servicing distribution by functional zones of St Petersburg, 1996-2002

Source: Calculated on the basis of telephone directories 1996, 2002.

The case of automobile servicing exemplifies the typical 'industrial zones oriented' branches (Figure 5.4 ). The majority of automobile servicing facilities were located, unlike in previous cases, in and on the fringes of the industrial areas. However, the location of new automobile servicing businesses in the courtyards of the historical quarters in the city centre represents the emergence of a new locational trend between 1996 and 2002.

The 'dispersed' type of locational preference is illustrated by hotels, 


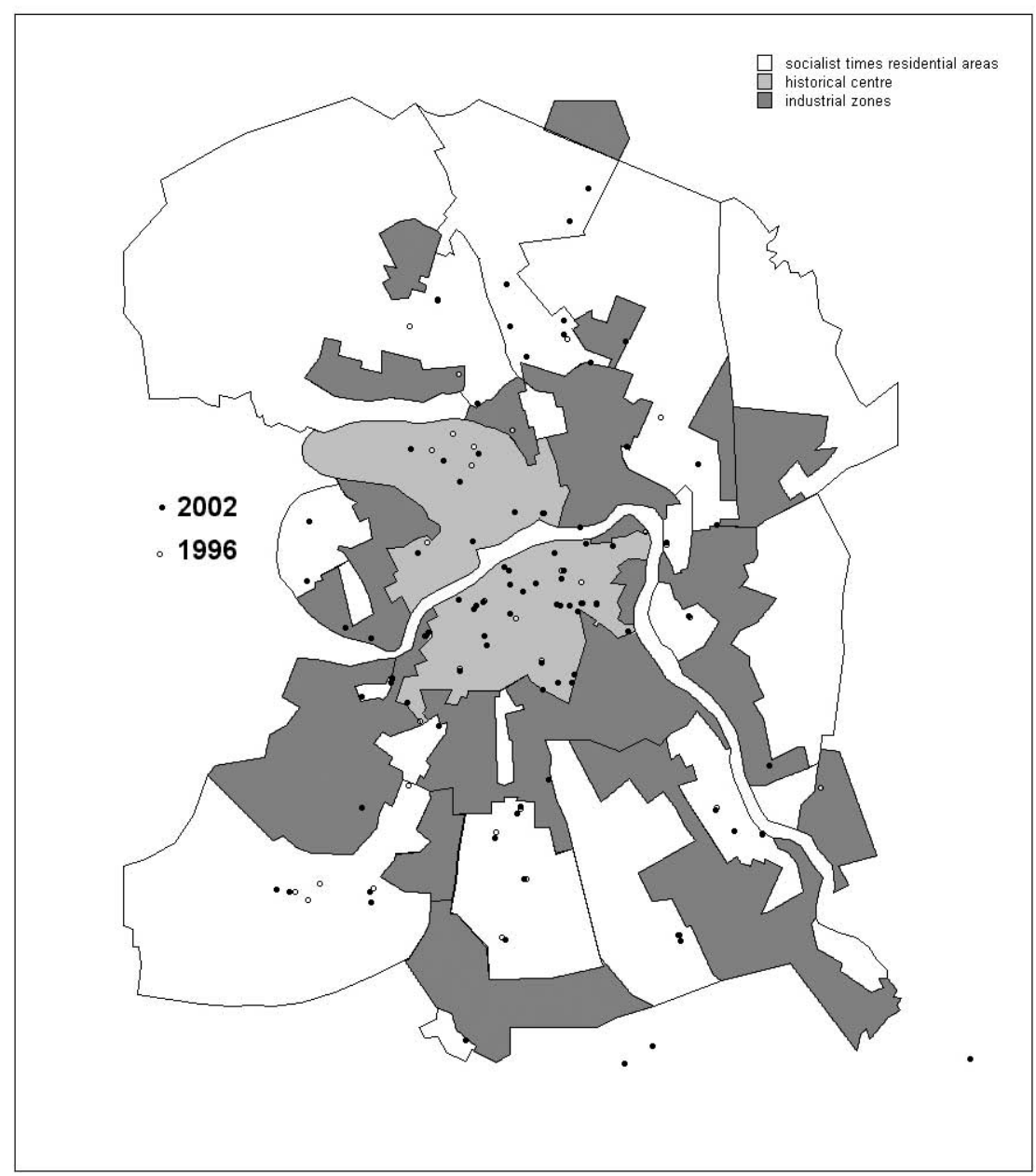

Figure 5.5 Hotels distribution by functional zones of St Petersburg, 1996-2002 Source: Calculated on the basis of telephone directories 1996, 2002.

which could be found quite evenly distributed in all morphological zones of the city (Figure 5.5).

A comparison of these maps demonstrates several facts. First, urban morphology has continuously acted as major factor contributing to variations in the pattern of business location. Second, morphologically similar parts of the city show different degrees of attractiveness for the facilities of a given branch. Third, some areas outside the historical centre of the city have definite features of centrality, as indicated by the concentration 
of centrality oriented branches there. These are areas dominated by housing and located close to the centre, with good transport ties. A very special case is represented by the ribbon of Moskovski avenue, the main southbound highway in the city, which crosses all the morphological zones. All along its route the adjoining areas have distinctive features of centrality. How can these patterns be explained?

\section{Transportation patterns and the distribution of retail trade and services}

Most of this variation can be explained by transportation patterns and related effects. Hence, transportation patterns constitute the second major spatial factor of retail trade and services distribution. Zones of concentration of retail and service activity under otherwise equal conditions tend to follow the main transit routes for automobiles and metro lines. This dependence is more marked the more important the route is. In the case of highways, the importance as a centre of gravity for retail trade and services depends on the following factors:

- The transit function: the straighter the course of the highway from the centre to the outskirts of the city, the more important it is.

- Destination: the direction of the highway is very significant. The most important routes are those leading to international destinations (Helsinki, the western Russian border), to the international airport and to Moscow, followed in diminishing order of importance by those leading to other Russian centres such as Murmansk, then to the most popular resort areas in the St Petersburg region and lastly to some of the industrial centres around St Petersburg.

- Links and accessibility: the more roads connected to the highway, the greater its importance.

- Competitiveness: the importance of the highway depends on the nature of alternative routes that lead in the same direction.

- The actual traffic: the volume and type of traffic are of significance. The most attractive locations for businesses are along major transit highways carrying predominantly car and public transport traffic. Highways used equally by cars and trucks are less attractive centres of gravity for retail and service facilities; transit routes used almost exclusively by trucks are least attractive.

The influence of transportation patterns on the distribution of retail and services is, however, primarily indirect. It is channelled through the physical structure of the city, which results from planners prioritizing the main arteries, such as highways and metro lines. City planners located many service and infrastructure objects along the main highways and around metro stations, and the development of new housing and office zones was 


\section{Vertical business structures}

usually linked to the main regional axes. Major transit routes from the socialist period were principal elements in the post-socialist development of the city.

The importance of major highways for the development of the retail and services business can be seen very clearly in Figures 5.6 and 5.7, which show the density of retail and services facilities along various streets. In order to measure this density, we first counted the number of businesses

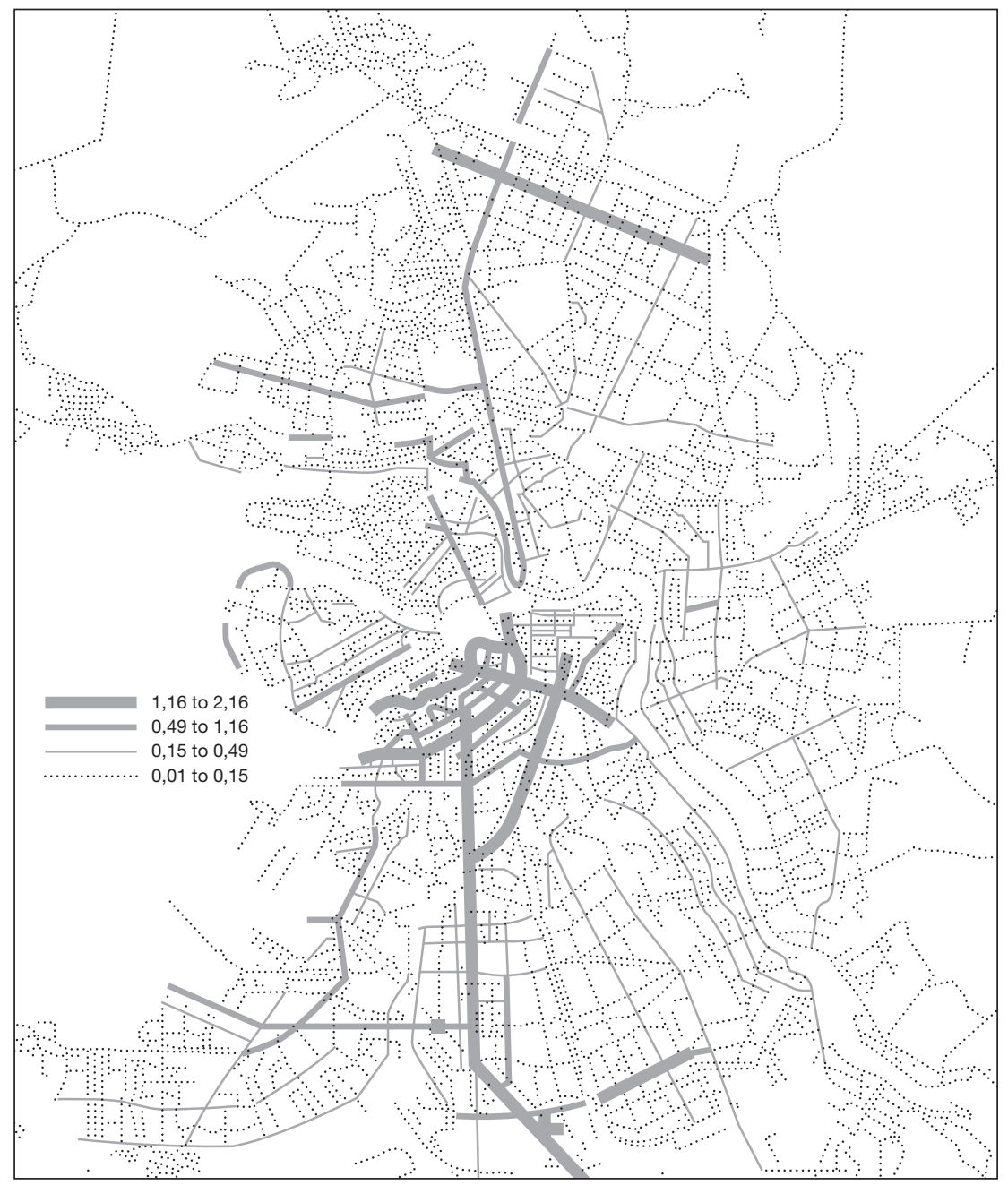

Figure 5.6 Number of facilities of ten model branches, 1996, by average length of building; see description of the index in the text

Source: Calculated on the basis of telephone directory 1996. 
in a street belonging to the ten most representative (according to our observations) and/or largest (in terms of the number of facilities) 'centrality' and 'centrality and locality' oriented retail and services branches. These branches are as follows: good-quality restaurants; tourist companies and travel agents; banks - central offices and affiliates; real estate; computer hardware and software; insurance; cafes and bars; furniture trade; audio, video and electronics. Second, we weighted the amount of retail and

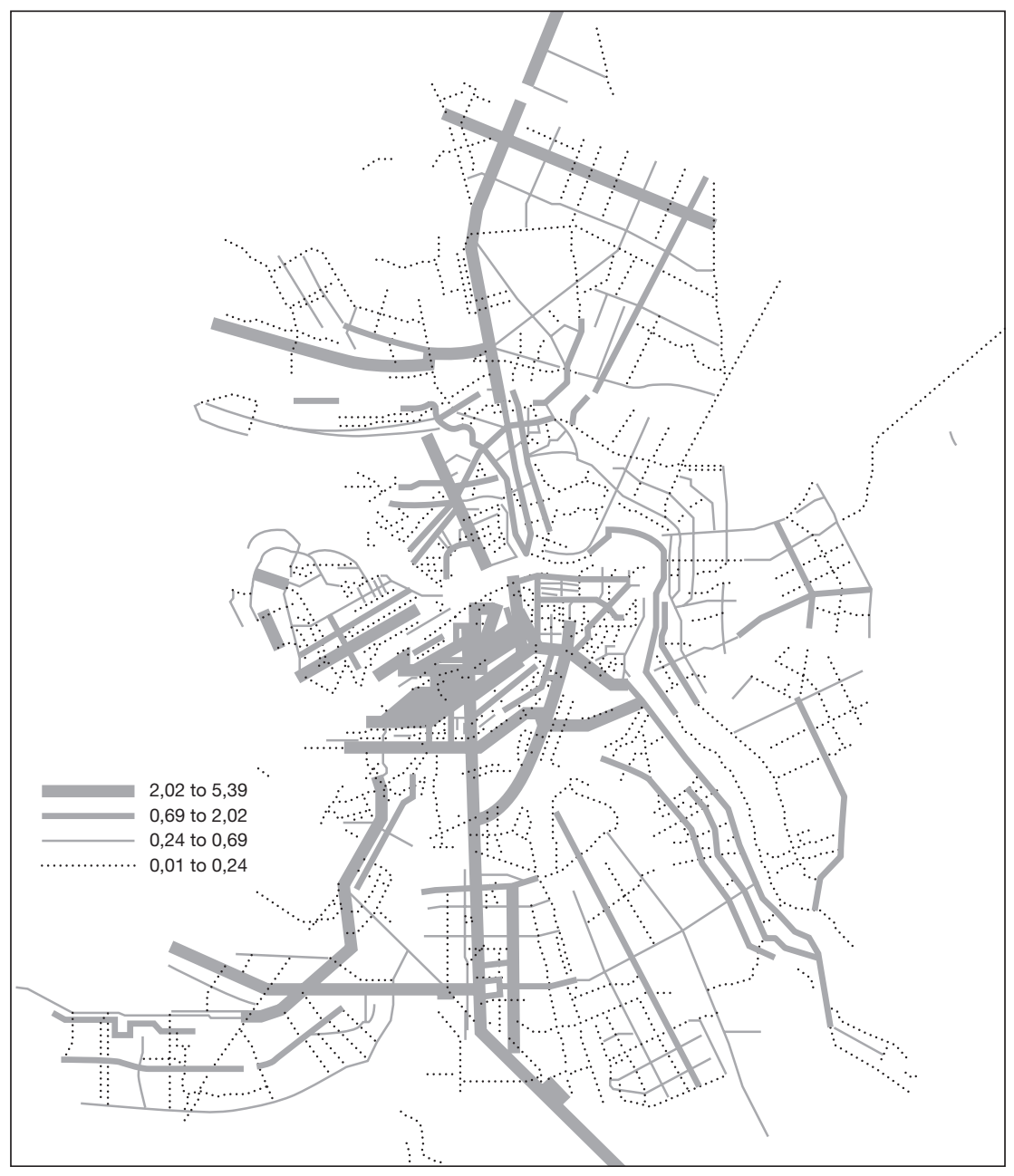

Figure 5.7 Number of facilities of ten model branches, 2002, by average length of building; see description of the index in the text

Source: Calculated on the basis of telephone directory 2002. 


\section{6}

services facilities found in each street by the average building length, so that the objective capacity of each street to accommodate retail and services business establishments could be compared.

The concentration of business facilities along major highways increased between 1996 and 2002, and distinct 'leaders' appeared in all the areas outside the historical centre. New highways such as the Engelsa Avenue leading to the north became major gravitation centres for business location.

The varying attractiveness of different highways to retail and services branches not only results in a linear, strip-like pattern of location directly adjacent to the highways but leads to the formation of a sectoral spatial system affecting all the adjoining areas and streets. Figures 5.6 and 5.7 show the division of the socialist era residential belt into eleven sectors that vary according to the pattern of transportation and resulting attractiveness for the retail and services business.

\section{General model and dynamics of the distribution of retail trade and services}

Combining the two major factors of urban morphology and transportation patterns results in a macro model of the distribution of the retail and services industry within the city (see Figure 5.8). This model has a classical circular-radial structure, ${ }^{5}$ and consists of three concentric zones (central, industrial and residential), 11 sectors determined by transportation patterns, which divide up the socialist era residential belt, and two segments that represent the exceptions from the circular-radial rule (numbered 3 and 13).

Figure 5.8 provides further evidence of the rising value of the centre and inner industrial belt of the city as a location for retail and services between 1988 and 1996. Furthermore, it shows that the relative pace of changes differs significantly between different sectors of the socialist era residential belt. This indicates that our model is a working reflection of reality.

Detailed study of Figure 5.8 shows that in the residential zone, the most rapid changes in the density of facilities took place in the sectors with the most favourable transportation patterns. We have already mentioned that socialist planners used to distribute retail and services functions along the main transportation arteries. Yet the influence of transportation patterns on business geography became even more important under market conditions.

Figure 5.9 shows that the circular-radial rule continued to influence the pattern of business distribution in retail and services. ${ }^{6} \mathrm{~A}$ 'leader' in attracting new facilities appeared in the north of the city (sector 12). The three rapidly developing socialist era housing sectors in the south and south-west of the city represent the areas with better transportation links (sectors 4, 6, 9). 

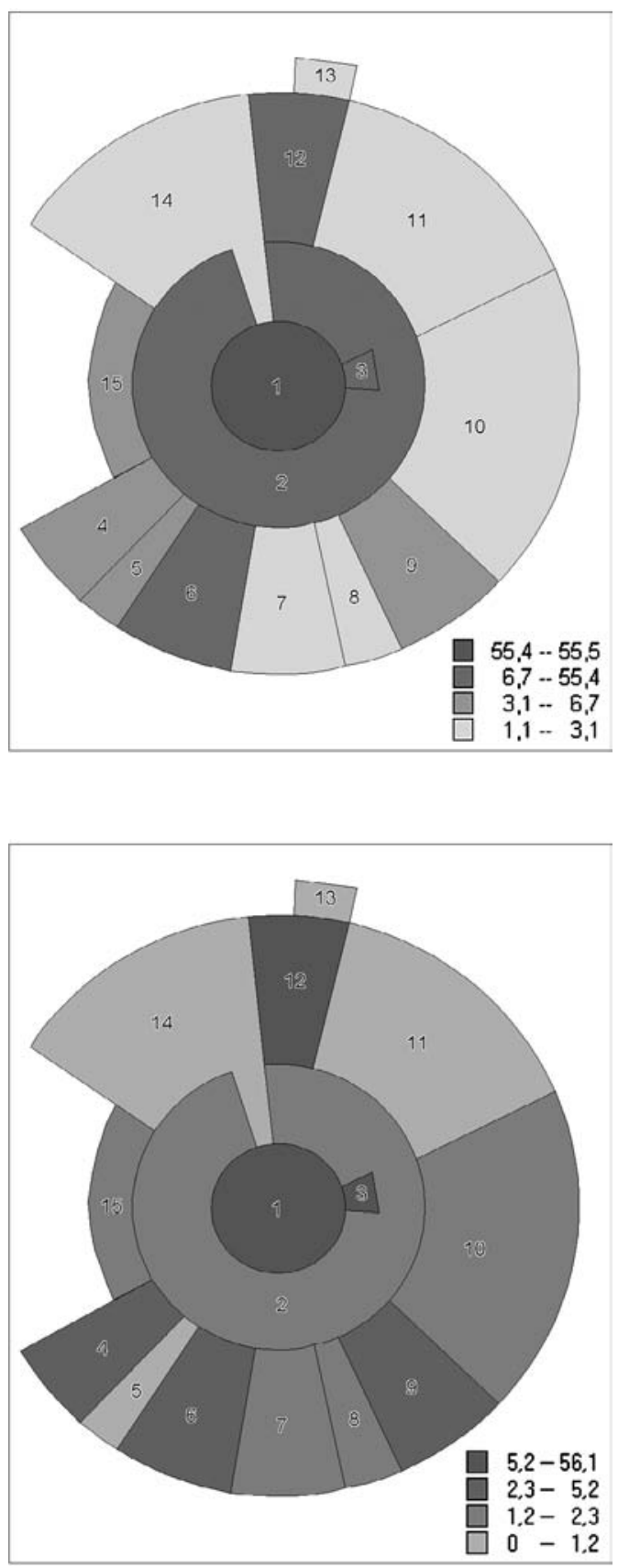

Figure 5.8

Changes in density of 55 branches' facilities, 1988-96, by 15 model zones

Source: Calculated on the basis of telephone directories 1988, 1996, 2002.
Figure 5.9

Changes in density of 19 selected branches' facilities, 1996-2002, by 15 model zones

Source: Calculated on the basis of telephone directories 1996, 2002. 
It is very instructive to analyse the reasons for the existence of the inherited differences, as well as the cases of market corrections that we observed.

Two sectors (number 5 and 8) represent protrusions of the industrial zones from the 1930s-1970s that almost fully separate the adjoining residential areas; they developed along the railways leading from the city centre. These industrial zones are linked to the inner industrial belt and do not differ too much morphologically from the latter. The same could also be said about the outer segment, which corresponds to one of the newest industrial zones on the outskirts of the city (segment 13). In spite of the morphological similarities among all industrial zones, the processes at work in these three areas (number 13, 5 and 8) with regard to the distribution of retail and services differ substantially from those of the inner industrial belt (zone 2). Whereas between 1988 and 1996 the relative density of the facilities in the inner belt increased significantly, none of the three industrial areas mentioned above showed such rapid changes. And both sector 5 and segment 13 demonstrated a lower rate of density increase between 1996 and 2002 as well. Why? We tend to see the answer in the advantages that the inner belt as a geographical location can offer businesses in the retail and service industries. The inner belt has an important transit function on a city-wide scale, which is not the case for sectors 5,8 , and segment 13 .

The areas with the highest density of facilities in 1988, 1996 and 2002 were sectors $6,9,15,12$ and 4 , as well as segment 3 .

In segment 3, close to the centre and very accessible, the important transit road and the already highly developed state of retail trade and services in socialist times mean that this area is now almost equally attractive for retail trade and service activity as the centre. Proximity to the centre definitely influences the development of sector 15 , too, though to a much lesser extent. We see the explanation for this fact in two geographical differences between these parts of the city. First, sector 15 , unlike segment 3, represents a dead end for both the overground transport system and the metro system. Second, in contrast to segment 3, sector 15 is separated from the centre by the industrial areas. This example illustrates the significance of the two major factors that we consider in our model.

The combination of several factors makes sector 6 a unique part of the city - features of centrality can be observed throughout the whole sector, from the centre down almost to the city limits. This is a consolidated area that surrounds a major transportation route, which includes 
a metro line running parallel to the most important highway in the city that leads to the airport, the Moscow highway and the resort areas of the region. The major highway also has links to the other important roads. This transportational monopoly produced a ribbon as attractive for business as the centre. No wonder that it has kept its status as the 'spine' of the city since socialist times.

Sector 4 combines the features of segment 3 and sector 6 , and the parts of the sector where the only important highway converges with the metro line close to the city centre form an equally attractive location for retail and services facilities as these areas. Further to the south this transportational monopoly breaks into four important routes: highways leading to the Russian western border, to Moscow, to the resort areas and to the metro line. All of them have easy links to the other major transportation routes. The area here is obviously well developed and does not have distinct centres of retail trade and service businesses concentration. This sector also inherited its favourable position for business development from the socialist period.

The effect of the transportation model and related developmental factors can be observed by comparing the patterns of business distribution for the last two sectors described with the two adjoining southern sectors, number 7 and 9 .

One of the most densely populated, sector 7 is now probably the most underdeveloped area of the city in terms of the presence of 'centrality' and 'centrality and locality' oriented branches. There is not a single concentration of facilities belonging to such branches in this sector, despite its morphological similarities with sectors 4, 6 and 9. This situation stands in complete contrast to the situation under socialism, when this sector was one of the most developed in terms of retail and services facilities. Between 1988 and 1996, it experienced the most dramatic loss of attractiveness as a location for new retail and services businesses in the whole residential belt. Why was this? The main reason for this decline is the absence of transit routes leading out of the city in this sector, plus a poor metro connection and the presence of three equally inconvenient public transport connections with the centre. All this contributes to the combination of low 'centrality' type attractiveness with a potentially high degree of dispersion.

In contrast, the much less densely populated residential areas of the neighbouring sector 9 are the location for rather intensive development by the different types of retail trade and services branches, even by some 'centrality' oriented ones. The reason for such a striking difference is, in 
our opinion, once again the pattern of transportation. In sector 9, as in sector 7, there are three major highways of equal importance that can compete with each other in attractiveness as locations for the retail and service industries. However, the crucial differences are that in sector 9 all three highways lead straight out of the city, which makes them potentially much more attractive, and that a metro line runs parallel to these highways.

Generally, the eastern and northern sectors are less attractive for the retail trade and services business. This is obviously related to the much less favourable transportation pattern. Clusters of business activity can be observed only in the areas that are most developed from a transportation perspective - parts of sector 11 where a metro line follows a non-transit yet major highway, plus areas surrounding major highways and metro stations in sectors 12 and 14. For both sectors 12 and 14, the intensity of business activity declines with increasing distance from the centre of the city. In sector 14 , the growing attractiveness of the territory directly bounding the only important highway is cancelled out by the underdevelopment of the retail trade and services in the rest of this vast sector. A similar artery in sector 12 is surrounded by a much smaller area, making growth in that sector more visible.

Sector 12 exhibited the highest growth in density of the facilities among the socialist era residential sectors between 1996 and 2002. We tend to attribute this process to the increased attractiveness of the major highway and metro line there. After the collapse in the mid-1990s of the northeastern metro line, which leads to sector 11, massive passenger flows were redirected to the north-bound line going through sector 12, making this the busiest metro line in the city. The major highway that runs more or less parallel to the metro line has also increased in significance, since most of the commuters have to change to overground means of transport to go eastwards. Despite rapid development in 1996-2002, sector 12 is far from being as attractive to 'centrality' and 'centrality and locality' oriented branches as sector 6 is. We tend to see its development as a temporary phenomenon, which will probably stop or at least slow down considerably after the reconstruction of the collapsed metro line.

Although, at least in terms of the density of facilities, the majority of the sectors inherited their relative position on the city map from the socialist period, in some cases market forces made some very important corrections to the old socialist pattern.

The numerous examples described in this section prove that we are correct in our choice of morphological zoning and transportation patterns 
as the main factors governing macro-differences in the distribution of retail trade and services in St Petersburg under market conditions.

\section{Structure of the retail and services business and urban geography}

The last issue that we want to discuss here is the interdependence of the structure of the retail and services business and urban geography. Did this structure differ among the sectors, zones and segments of our model under both socialist and market conditions? Did any important shifts occur in the structures of the zonal/sectoral branches between 1988, 1996 and 2002, and if so, what were the reasons for this?

In previous publications, we have examined in detail the changes that took place in the business structures of the 15 model zones on the basis of 55 branches (Axenov, 2001). Here, we have added the analysis of zonal structural dynamics, comparing data on 19 selected branches for 1996 and 2002. In both analyses we used the same indicator. We wanted to show not only the most numerous branches for each zone/sector of the model but also those branches that distinguish each zone from the average citywide pattern. So we studied only those branches in a sector whose facilities as a percentage of the total retail and services facilities in that sector exceeded the average for the whole city. We believe that the branches of specialization chosen by such a criterion can be considered 'zone-shaping', since they describe the function of a certain zone/sector/segment in the city-wide pattern of retail and services distribution. In addition to our previous findings for 1988-1996 (Axenov, 2001), we have composed two tables depicting the major trends for 1996-2002 (Tables 5.5 and 5.6).

It is apparent that substantial changes took place in the structures of the 'zone-shaping' branches in all three major concentric morphological zones of the city between 1988, 1996 and 2002. Let us discuss these, following the concentric structure.

\section{Historical centre}

In 1988, the branches of main specialization in the city centre were three different branches of the catering trade, dressmaking and tailoring. The same branches could be found in the areas closest to the centre - sector 15, zone 2 and segment 3 in Figure 5.8. This reflects the main principles implemented by socialist planners - spatial hierarchy on the basis of the demand frequency and orientation towards the needs of local and tourist visitors to the centre. Planners seemed unconcerned by the morphology of the environment, so leisure facilities appeared in easily accessible areas adjacent to the centre, even industrial ones.

By 1996, of the old branches of specialization only cafes and bars remained among the most important branches in the centre. The rest of 
Table 5.5 Number of 19 selected retail and services branches that represent branches of specialization for each of the 15 model sectors/zones of St Petersburg, 1996-2002

\begin{tabular}{llll}
\hline Sector/zone & $\begin{array}{l}\text { No. of branches } \\
1996\end{array}$ & $\begin{array}{l}\text { No. of branches } \\
2002\end{array}$ & $\begin{array}{l}\text { No. of branches } \\
\text { retained between } \\
1996 \text { and 2002 }\end{array}$ \\
\hline 1 & & & 10 \\
2 & 11 & 10 & 5 \\
3 & 7 & 7 & 5 \\
4 & 8 & 7 & 5 \\
5 & 7 & 7 & 3 \\
6 & 6 & 5 & 7 \\
7 & 10 & 9 & 5 \\
8 & 6 & 7 & 4 \\
9 & 5 & 10 & 6 \\
10 & 6 & 6 & 5 \\
11 & 5 & 8 & 6 \\
12 & 9 & 8 & 5 \\
13 & 9 & 2 & 0 \\
14 & 2 & 8 & 5 \\
15 & 7 & 10 & 5 \\
\hline
\end{tabular}

Note: Numbering of sectors/zones as per the model in Figure 5.8.

the top five 'zone-shaping' branches belonged to the 'centrality oriented', random demand 'boom' branches - computers, tourism, legal and construction services. The centre differed from all other zones in the city in that it contained a much greater number of branches whose facilities as a percentage of the total retail and services facilities exceeded the average for the whole city. Most of these branches are characteristic for the centre only. This would seem to reflect the trend towards greater concentration and spatial specialization in the retail trade and services as a whole.

Between 1996 and 2002, the city centre retained most of its 'zoneshaping' branches -10 out of 11 (Table 5.4). No new branches of specialization were added during this time (Table 5.5). These facts reflect the relative stability of the business structure within the centre. The largest of the 19 selected branches in 2002 were publishing, tourism companies, cafes and bars, telecommunications and computer companies. At the same time, though, the centre no longer has the greatest number of 'zoneshaping' branches (Table 5.4). Segment 3, in close proximity to the centre, demonstrated attractiveness both for 'centrality oriented' branches and branches characteristic of residential areas.

\section{Industrial zones}

In socialist times, retail trade and services were least developed, in terms of the number of facilities and the variety of branches, in the industrial 
Table 5.6 Changes in the branches of specialization for each of the 15 model sectors/zones of St Petersburg, 1996-2002

\begin{tabular}{|c|c|c|}
\hline $\begin{array}{l}\text { Sector/ } \\
\text { zone }\end{array}$ & $\begin{array}{l}\text { Branches lost between } 1996 \\
\text { and } 2002\end{array}$ & $\begin{array}{l}\text { Branches added between } 1996 \\
\text { and } 2002\end{array}$ \\
\hline 1 & Audio, video, electronics & - \\
\hline 2 & $\begin{array}{l}\text { Furniture trade } \\
\text { Cargo shipment }\end{array}$ & $\begin{array}{l}\text { Investment and financial services } \\
\text { Publishing }\end{array}$ \\
\hline 3 & $\begin{array}{l}\text { Hotels } \\
\text { Good quality restaurants } \\
\text { Hairdressing, cosmetics }\end{array}$ & $\begin{array}{l}\text { Cargo shipment } \\
\text { Computer hardware and software }\end{array}$ \\
\hline 4 & $\begin{array}{l}\text { Investment and financial services } \\
\text { Automobile servicing }\end{array}$ & $\begin{array}{l}\text { Furniture trade } \\
\text { Cafes, bars }\end{array}$ \\
\hline 5 & $\begin{array}{l}\text { Insurance } \\
\text { Auditing, consulting, marketing } \\
\text { Banks: affiliates }\end{array}$ & $\begin{array}{l}\text { Telecommunications } \\
\text { Food stores }\end{array}$ \\
\hline 6 & $\begin{array}{l}\text { Computer hardware and software } \\
\text { Auditing, consulting, marketing } \\
\text { Tourism companies and travel agents }\end{array}$ & $\begin{array}{l}\text { Banks: affiliates } \\
\text { Automobile trade } \\
\text { Cargo shipment } \\
\text { Furniture trade } \\
\text { Telecommunications }\end{array}$ \\
\hline 7 & Computer hardware and software & $\begin{array}{l}\text { Cargo shipment } \\
\text { Audio, video, electronics } \\
\text { Furniture trade } \\
\text { Cafes, bars }\end{array}$ \\
\hline 8 & Hotels & $\begin{array}{l}\text { Banks: affiliates } \\
\text { Real estate } \\
\text { Food stores }\end{array}$ \\
\hline 9 & - & $\begin{array}{l}\text { Banks: affiliates } \\
\text { Cargo shipment } \\
\text { Audio, video, electronics } \\
\text { Publishing }\end{array}$ \\
\hline 10 & - & Telecommunications \\
\hline 11 & $\begin{array}{l}\text { Investment and financial services } \\
\text { Good quality restaurants }\end{array}$ & $\begin{array}{l}\text { Audio, video, electronics } \\
\text { Telecommunications }\end{array}$ \\
\hline 12 & $\begin{array}{l}\text { Automobile trade } \\
\text { Real estate } \\
\text { Auditing, consulting, marketing } \\
\text { Computer hardware and software }\end{array}$ & $\begin{array}{l}\text { Hotels } \\
\text { Audio, video, electronics } \\
\text { Furniture trade }\end{array}$ \\
\hline 13 & $\begin{array}{l}\text { Automobile servicing } \\
\text { Cargo shipment }\end{array}$ & $\begin{array}{l}\text { Publishing } \\
\text { Food stores }\end{array}$ \\
\hline 14 & $\begin{array}{l}\text { Hotels } \\
\text { Insurance }\end{array}$ & $\begin{array}{l}\text { Banks: affiliates } \\
\text { Auto service } \\
\text { Cargo shipment }\end{array}$ \\
\hline 15 & Computer hardware and software & $\begin{array}{l}\text { Automobile trade } \\
\text { Cargo shipment } \\
\text { Automobile servicing } \\
\text { Auditing, consulting, marketing } \\
\text { Good quality restaurants }\end{array}$ \\
\hline
\end{tabular}

Note: Numbering of sectors/zones as per the model in Figure 5.8. 


\section{4}

areas of the city depicted in the model. This was especially the case for the peripheral industrial sectors, 5 and 8 . Nevertheless, the structure of branches found there differed very distinctly from the rest of the city. In 1988, three branches were very characteristic for the industrial zone as a whole - cargo shipment, automobile servicing, open-air overnight car parking and self-service restaurants. All were oriented towards the morphology of the territory - cargo shipment served the industrial enterprises, self-service restaurants served the employees of these enterprises, and automobile servicing normally used the facilities of certain industrial sites and served both business and private customers, parking facilities normally used the least valuable territory, rather far away from potential customers. Goodquality restaurants were numerous in the inner industrial belt due to the proximity to the centre as mentioned above.

By 1996, the number of the 'zone-shaping' branches in the industrial zone had increased, but the traditional branches of cargo shipment, auto service and overnight parking retained their status. However, parking geography changed, moving closer to the fringes of adjoining residential areas in a search for local customers. Self-service restaurants declined with the industrial crisis. In St Petersburg, the phase of gentrifying the industrial belt, as in some Western and East European cities, had not yet been reached, so good-quality restaurants inevitably disappeared. New branches started to play an important role there - activities related to car maintenance, wholesale trade, construction services and even banking. Most of these branches seek relatively large sites and preferably a city-wide clientele. This last demand means that relatively equal and easy access from all parts of the city is required. These are features that industrial zones could offer at the lowest cost.

Between 1996 and 2002, the industrial zones preserved their city-wide specialization in automobile servicing and cargo shipment, while two new branches of specialization seem to have emerged - food stores and publishing. Publishing became one of the 'zone-shaping' branches in two industrial zones/sectors -2 and 13 . We have already mentioned that publishing is one of the most numerous branches of zonal specialization in the city centre, so it seems quite logical to suppose that the over-saturation of the city centre with this branch has led to some publishing facilities being 'pushed out' to the industrial belt. The same assumption could be made for telecommunications, which had become the 'zone-shaping' branch for the inner industrial belt by 2002. At the same time, while food stores represent the most important 'zone-shaping' branch for most of the socialist era residential areas, competition within this branch, as we have already mentioned, led to a process of concentration, which resulted in the reduction of the total number of food stores and the development of larger trade forms. It is likely that, in the context of this sharp competition, food stores oriented towards local customers began to explore new commercial locations in formerly less favourable areas, such as the industrial zones. 


\section{Socialist era residential areas}

In 1988, the majority of the residential sectors in our model were distinguished from the rest of the city by the dominance of repair services, laundry, dry cleaning, hairdressing and cosmetics, state bank affiliates and, in some sectors, consumer goods retail. Such a structure was a reflection of both the Soviet type consumption model and socialist principles of location. The Soviet consumption model was characterized by the total shortage of consumer goods, which resulted, partly, in the necessity to prolong the life of each product. This supply deficit was thus compensated for by the development of a vast array of consumer goods maintenance services. The socialist principle of spatial hierarchy required that all necessary services with periodical demand, such as bank affiliates and consumer goods stores, be located proportional to population density in each residential area. Interestingly, overnight parking played an important role for the northeastern residential sectors only. Perhaps the neighbouring industrial zones were supposed to provide this service for the south-western sectors.

By 1996, food stores and consumer goods stores had become branches of specialization in most of the residential belt. Parking and repair services preserved their 'zone-shaping' role. In some residential sectors cafes and bars and legal services were added to the list of specializations. Most of these branches are of the 'locality' and 'locality and centrality' oriented types, and of periodical and everyday demand, which is quite usual for residential areas. However, in comparison to the socialist period, the main branches showed greater variety, with branches other than the 'localityoriented' type beginning to play an important role in some sectors. These include: tourism companies and travel agents, wholesale trade, construction services and the furniture trade. It is difficult to claim that city-wide centres of specialization in these branches appeared in certain residential sectors, but there is no doubt that the general spatial structure of the trade and services business became more complicated. At the very least, the determinism of the socialist principle of spatial hierarchy has been seriously disturbed. The changed structure of branches of periodical and everyday demand in residential areas reflected the general shift from the socialist to the Westernized model of consumption. The leading role in such areas passed from consumer goods maintenance to the consumer goods trade.

In the period to 2002, the branches of everyday and periodical demand enhanced their significance as the 'zone-shaping' branches in the socialist era residential zones. Food stores and consumer goods stores, cafes and bars were the branches of specialization for most of these areas. In an interesting development, the segment in closest proximity to the centre, segment 3, started to lose 'centrality oriented' branches and assumed the features of the residential areas. Similarly, rapidly developing sector 12 lost 'centrality oriented' functions during this period, in spite of 


\section{6}

experiencing the largest increase in the density of facilities of any model sector between 1996 and 2002; it also attracted branches of specialization typical of residential areas. This was, however, not the case in sector 6, which very definitely preserved its role as a secondary core in the city. It retained all its branches of specialization from 1996 (which were mostly of the 'centrality' type) and gained some new ones.

The main conclusions to be drawn in this chapter are as follows. The set of general principles/factors of retail and services geography has remained almost unaltered since socialist times, but their relative significance has changed. The priorities of socialist planners were related to the principles of spatial hierarchy, transportational/developmental ribbons and urban morphology. The same factors affect the location of businesses under market conditions. But the leading role played by the factors of urban morphology and the patterns of transportation has replaced the overall dominance of the principle of spatial hierarchy that prevailed under socialist planners.

The general spatial structure of the whole retail and services sector in St Petersburg became more complicated. Recent changes show the trend towards greater concentration and spatial specialization. The main outcomes of this trend are twofold. First, the value of the centre and inner industrial belt of the city for the retail trade and services is generally rising, while the relative importance of the residential belt declines. During the early transformation period, between 1988 and 1996, the centre increased its share of retail and services facilities, although this later declined slightly. The industrial belt experienced continuous growth in its importance to the retail and services business. The share of facilities in residential areas, relative to other areas, has kept declining throughout the post-socialist period. Second, the relative rate of change differs significantly between the various sectors of the socialist era residential belt, and the highest growth in retail and services took place in those sectors with most favourable pattern of transportation.

The changes in the structure of the retail and services business took different directions in different morphological zones of the city. This fact reflects the critical importance of the urban morphology factor for the location of the business within the city, as well as the formation of different markets for commercial space in different morphological zones of St Petersburg. 


\section{Territorial complex building}

Along with the development of vertical business structures, territorial complex building (or the emergence of horizontal structures) constitutes the process for the spatial saturation of the transformation city with consumer goods and services. As we have outlined before, territory itself contributes to the creation of certain forms of interdependence between the individual establishments that appear on this territory. ${ }^{1}$ By territorial complex, we understand a system of individual facilities that emerges at a particular location as a result of the specific features of that location - i.e. the particular combination of business structures and urban infrastructure there. The individual establishments within a complex are interdependent - most of them would have never appeared or survived in this particular business location without the presence of the other members of the territorial complex; all businesses located within the complex have a locational advantage over other businesses that are not part of the complex, because they benefit from the additional customers attracted by the complex as a whole, rather than just by their individual businesses. For this reason, individual or even branch business interests are somewhat subordinate to the interests of the complex. Thus, individual establishments will concentrate in one location, regardless of the competition between them. So, if in the case of vertical business structures, individual establishments were attracted by zones of consumer concentration, in the case of territorial complexes, individual businesses try to attract customers by forming spatial clusters.

In our study, we observed territorial complex building at different spatial scales - from micro-forms that could be measured in single square metres to macro-forms large enough to have a city-wide attraction. Four different types of territorial complex building appeared at all scales. These types differ in the principles and mechanisms of their operation. 


\section{Territorial complex building}

\section{Four types of territorial complex building}

\section{Cumulative effect or joint territorial attraction}

This effect leads facilities from the same branch to concentrate in one location. The concentration of establishments selling similar products and services means that there is tight competition between the businesses in the complex. However, the potential losses arising from the very tight competition are more than offset by the fact that, by virtue of its location in the complex, each establishment attracts a greater number of customers than it could attract otherwise. Losses due to the necessity to compete with others in the complex for customers are compensated by the attraction of additional customers looking for wider choice in one location.

At a micro-scale, we observed this effect in several kiosk agglomerations. In the kiosk business, a crucial advantage can be gained from a location that is just a few metres closer to commuter flows than that of the competition. During one of the administratively prescribed relocations of kiosks near the Udelnaya metro station, several kiosks became screened from the main commuter flows by a row of more favourably located ones (Figure 6.1a). Shopping at the former kiosks would require customers to ignore the front-row kiosks and depart from the most direct route between the metro and railway stations. There was no reason for customers to do so if they could buy the same products directly on their way. Traders selling the most common kiosk merchandise (cigarettes, beverages, prepackaged snacks, chewing gum, etc.) had to leave the unfavourably located kiosks. These kiosks remained empty for some time, and then they were removed and relocated. However, some traders soon returned, but with a very unusual specialization for the kiosk business. Most of the kiosks in the screened row started to sell the same type of meat products, competing with one another (Figure 6.1b). This competition forced traders to keep prices low and offer better-quality products. Furthermore, several meat traders in this row offered not only a rather large amount of the same sort of meat products but a wide variety of meat products as well. The combination of these factors motivated customers to come to this rather out-of-the-way location specifically to buy meat.

An example on a larger scale in the city centre is a roughly 400-metrelong section of the Zagorodny Avenue that accommodates 19 shops selling and repairing audio-visual and electronic goods. Good proximity to the metro and city centre makes this place very busy, not just with commuters, and at some point it became one of the major trading grounds in the city for audio-visual items and electronics. This means that the cumulative effect of competing shops locating together at one location became so great that this location as a whole started to attract a city-wide clientele. Additional customers from all over the city came here specially, looking for better choice and pricing, as was the case with kiosks on a much 


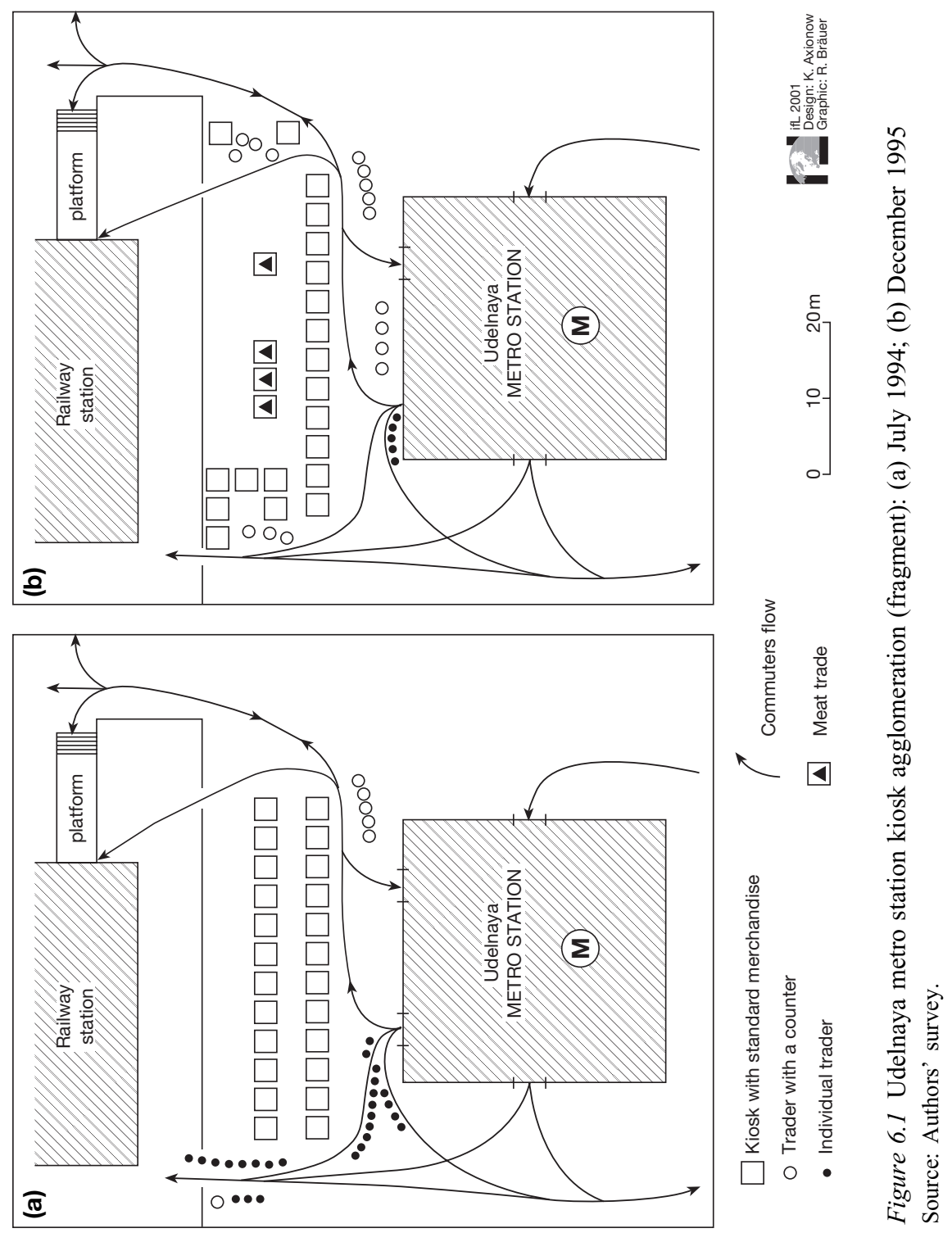


smaller scale. In interviews with business operators there, the majority of respondents outlined the concentration of establishments in the same line of business as the major favourable factor for their facility location. Some operators stressed that the rent levels in this location, some of the highest in the city, would be unacceptable for their business were it located elsewhere in the city, where this cumulative effect was absent. More detailed analysis of the Zagorodny Avenue territorial complex is included as an appendix to this chapter.

On an even larger scale, the cumulative effect is demonstrated by the desire to attract 'motorized customers' from all over the city. In the case of kiosk agglomeration, it led to the redirection of existing daily commuter flows. In the case of Zagorodny Avenue, the common location near the metro station was aimed at attracting customers who use public transport to get there from different parts of the city, as well as those with cars. The Kantemirovskaya-Grazhdanski complex includes several big construction and household goods stores and numerous small ones spread over a rather large area, located in close proximity to major regional highways. It is impossible to visit all of them on foot, but none is more than five minutes' drive from the other (see Figure 6.2). Most of those who shop here come by car, and tend to visit both seemingly separate parts of the complex.

While in the first case the spatial extent of a territorial complex was measured in dozens of square metres, and in the second case in hundreds of square metres, in the last case it was measured in square kilometres.

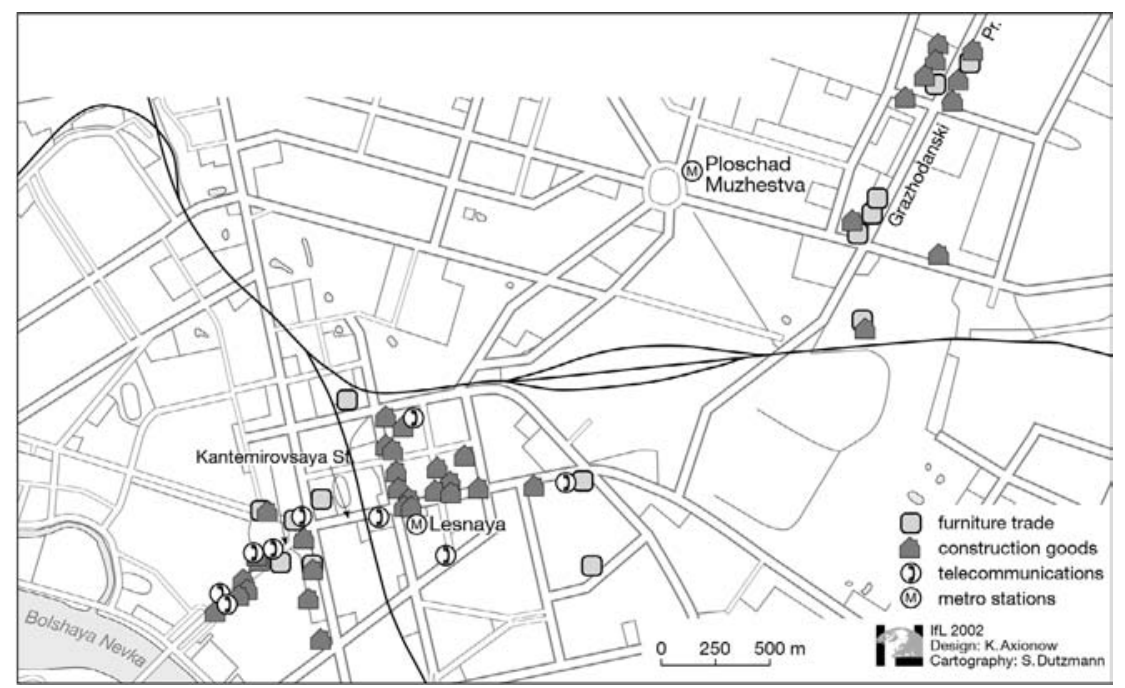

Figure 6.2 Kantemirovskaya-Grazhdanski territorial complexes, 1999

Source: Authors' survey. 
We suppose that, to some extent, the whole city centre represents a similar type of territorial complex, attracting a city-wide clientele due to the location of many similar facilities such as cafes, shops, etc. in close proximity to one another. This 'city-centre complex' is the largest scale at which the cumulative effect operates in the city. ${ }^{2}$ In all these cases, traders of the same specialization attract additional customers to a joint location. If it was not for the cumulative effect, these customers might never shop in this particular area. This means an interdependence of the traders involved that originates solely from the use of a common territory.

\section{Territorial attraction (co-operation) of interrelated branches}

In this type of territorial complex building, the traders or service providers that share a common location do not compete with one another as in the previous case. Instead they offer complementary goods and services. The fact that these facilities offer related services means that one trader's customer is a potential customer for the other traders in the area. Obvious potential effects of this are the multiplication of the number of customers and the substantial reduction in the advertising expenses of individual traders.

Complexes comprising builders' merchants, furniture stores and housekeeping goods outlets are found all over the city. The Salova Street territorial complex (like several other similar ones around the city) incorporates a big car parts market, car repairs, car servicing, car dealerships and petrol stations, etc. During the socialist period, this area accommodated one of the city's two large state-owned car repair depots as well as the state vehicle registration office. Roughly half of all private cars in the city were registered and repaired there. With the beginning of economic liberalization, the area started to play host to numerous car-related services. Obviously, new traders were orientated towards customers that came to visit the well-known state car repair depot. However, when one of the largest open-air markets selling car parts in the city opened in close proximity, the centre of gravity of the whole complex shifted from the old socialist car repair depot to the new market (Figure 6.3).

Importantly, this type of complex building is not necessarily orientated towards customers from one socio-economic level. Rather, such complexes normally tend to include traders of different price levels, thus widening the customer flow.

\section{Joint territorial attraction of targeted customers}

This is type of territorial complex does not necessarily host interrelated branches but rather tends to attract customers from a specific socioeconomic group. At one end of the variety spectrum, there are numerous 'shuttle'-type dry goods or food markets attracting customers with lower 


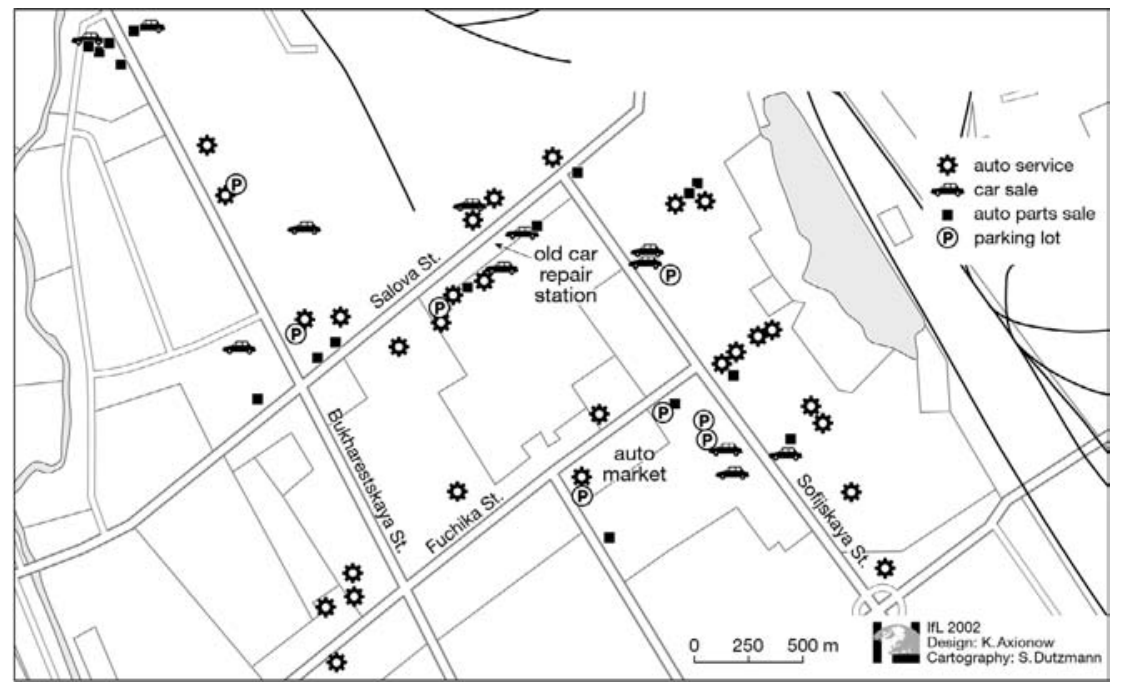

Figure 6.3 Salova street territorial complexes, 1999

Source: Authors' survey.

income levels, while at the other, there are the areas where very expensive boutiques, jewellers and entertainment facilities are concentrated, attracting a common clientele, the rich. Some locations of this latter type even use joint advertisements - in this case it is not the separate companies located there that are promoted, but the location as a whole.

Probably the best example of this type of elite complex is the Voznesenski 46 complex. This is one long building stretching for about 300 metres, offering well-equipped trading space and located in the very centre of the city. In many respects, it is inconveniently located away from public transport nodes, away from the main shopping and service areas and away from the major commuters flows. However, the major advantage of this location is an important motorway onto which the building faces. Since 1996, this building has hosted more than 10 elite facilities - an expensive nightclub, furniture stores, boutiques, etc. All of these are advertised as expensive and prestigious facilities for the elite. All attract clients with cars. Since 1996, this commercial location has experienced extremely high levels of tenant turnover - there have been very frequent changes in the shops and services comprising the complex. What all these retail facilities have in common is a very high premium price level. A unique feature is that despite being owned by different owners, these facilities tended not to advertise as individual companies, but to promote the location - Voznesenski 46. This advertisement was not paid for by the owner of the building but by the joint efforts of the separate companies located there. 
Our interviews with business operators at Voznesenski 46 revealed that all of them were dissatisfied with the disadvantages of this particular location, but none of them wanted to relocate their business. Advantages that were reported to compensate for the shortcomings were: good neighbours; convenient features of the building; the marketing and prestigious image of the location.

\section{Attraction to non-tertiary sector facilities}

This type of territorial complex building takes two forms:

1 Retailing and service facilities tend to serve the needs of a facility that does not belong to the tertiary sector. In St Petersburg, as elsewhere in the world, business centres and office zones attract cafes and restaurants of a certain type. Numerous logistics companies and customs brokers are located in the vicinity of the St Petersburg seaport. Railway stations attract various specialized trades and services. Large industrial enterprises all over the city became surrounded by kiosk traders and small shops. The list of examples could be continued. In all cases, retail trade and service outlets serve the needs of the people who work for, or use, a certain facility.

2 Retailing and service outlets tend to use the resources offered by a facility that does not belong to the tertiary sector. Some telecommunication companies, for example, are attracted by the research and production facilities of large institutions and tele-radio transmitting stations. Some such companies originate from within these institutions. An example of this sort of complex building is shown in Figure 6.2. The development of a telecommunications complex around the Kantemirovskaya Street is explained by the fact, that four large industrial electronics enterprises and research institutions are concentrated in this area. Most of the new private companies are connected to these four through technological and business links. Another very interesting example of the same type of complex is the Bolshaya Morskaya Street complex described in the appendix to this chapter.

The types of territorial complex building outlined above refer to the basic objectives for their creation. Along with this, we observed that complexes of each type could be built using different 'technology'. There are at least three basic mechanisms for all these types of territorial complex building:

1 Gravitational pull: one large or well-marketed/popular facility is surrounded by others that are attracted by its clientele. According to the type of complex formed, this might be to the benefit or to the detriment of this 'centre of gravity'. For example, in socialist times the 


\section{Territorial complex building}

Zagorodny Avenue, discussed above, was the location of one of the few, and hence well-known, audio shops and audio repair centres in the city. The first audio-visual and electronics shops that appeared there were attracted by this socialist type of promotional factor. Due to the development of a territorial complex selling audio-visual and electronic equipment, this location has preserved and even increased its city-wide prominence. The same effect is visible in the case of the Salova Street car-related territorial complex, described above. Examples of this sort are numerous, with some centres of gravity being inherited from socialist times, and some produced by the new market economy.

2 Territorial cooperation as a rational decision represents another mechanism. Probably the best example of this is the Voznesenski 46 complex. The important thing is that the rational decision to market the location as a whole, rather than the individual facilities, should not be made by the owner or developer of the whole location, but should, rather, be the result of cooperative action on the part of the businesses located there.

3 Spontaneous complex building is probably the most common type for the first period of transformation. Kiosk agglomerations could be ascribed to this type. These appear to be attracted to a particular location not so much by any specific object but rather by the volume of commuter flows.

Thus territorial complex building represents the second major mechanism for the spatial saturation of St Petersburg with retail and services facilities during the transformation period, alongside the spatial organization of emerging vertical business structures. As we have indicated, territorial complexes have emerged at different territorial scales but have followed the same principles of development according to the types and mechanisms of complex building.

\section{Appendix: the description of territorial complexes}

Detailed field research on the most prominent commercial zones was organized in summer 1997. Investigation of these areas included:

1 The creation of a detailed and complete map of the retail and service industries present in each area. The total number of enterprises localized on the map was 1,800 from 66 different branches. On the basis of these data, we determined some typical combinations of branches and were able to reach conclusions about territorial cooperation between branches in the tertiary sector, and about the differing degrees of attractiveness of the urban environment in particular areas for various branches. 
2 Plotting the type and construction style of buildings on the map enabled us to consider the differences in the economic conditions for enterprise location in different areas. After considering further elements of the urban environment such as construction zones, elite dwellings, 'informal' offices, public transport stops, etc., we increased the number of hypothetical complex-building factors.

3 After fixing the main urban environment parameters - traffic intensity, number of pedestrians and parked cars, etc. - we were able to determine location conditions for every site.

4 Interviews with entrepreneurs, employees and local inhabitants made it possible to reconstruct the historical development of commercial zones, as well as the reasons behind the choice of a particular business location by entrepreneurs. The interviews also showed how

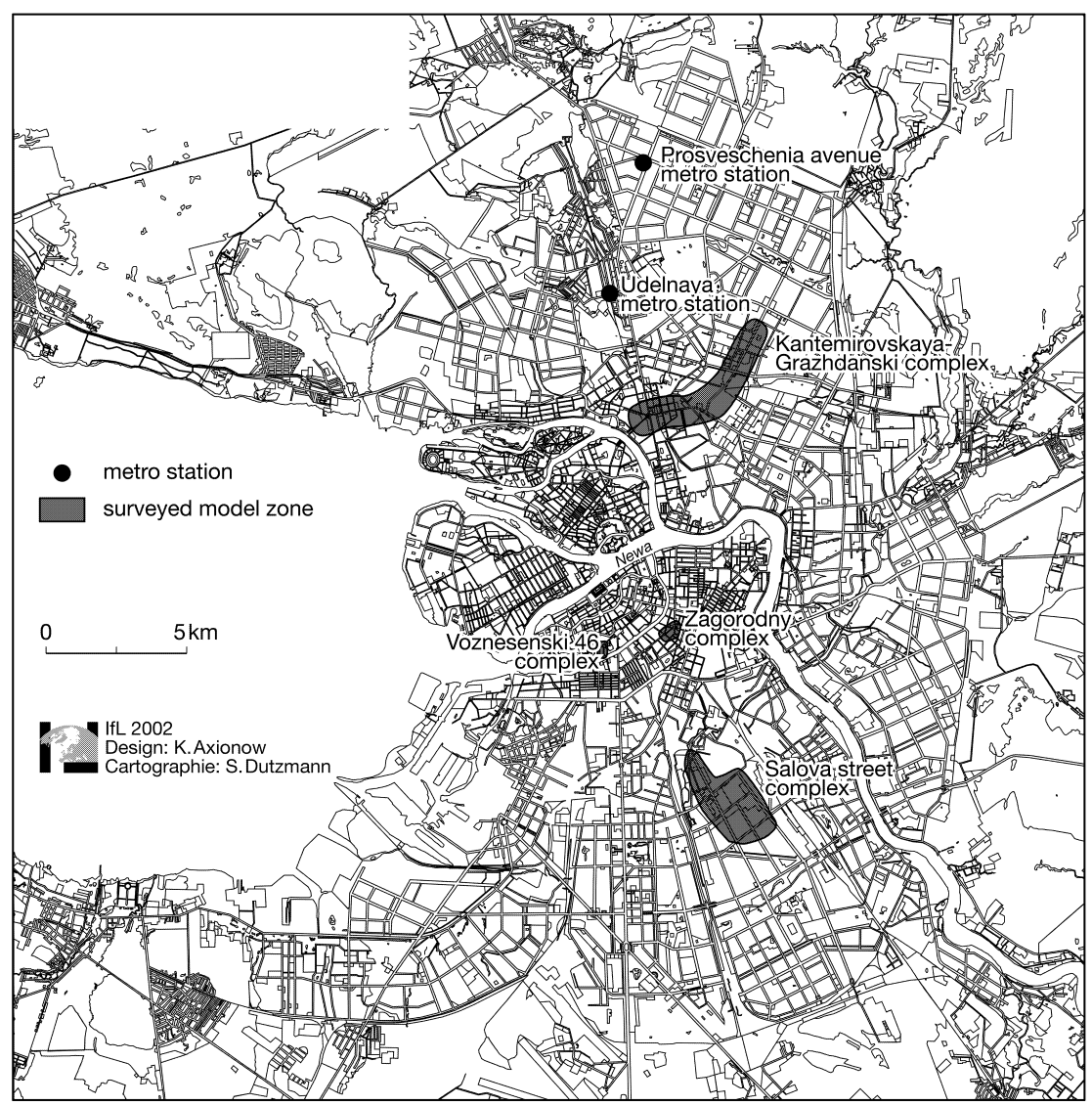

Figure 6.4 Surveyed model zones

Source: Authors' survey. 
entrepreneurs judged the conditions found at the location of their businesses.

All data from the field research were formalized and processed using geoinformational systems. The location of the zones described in this chapter is shown in Figure 6.4.

The investigated sites differed a lot in their main descriptions. So, to make the results comparable, we calculated some derivative indexes:

- $\quad$ dL(i) - tertiary sector enterprise density deviation per unit of the street length, calculated as follows: $\mathrm{dL}(\mathrm{i})=(\mathrm{n}(\mathrm{i}) *(\mathrm{~L}) /(1(\mathrm{i}) * \mathrm{~N}$, where:

i - section of the street;

$n(i)$ - number of the enterprises, with a main entrance situated on $\mathrm{i}$;

1(i) - length of i (in hundreds of metres);

$\mathrm{N}-$ total number of enterprises (of given branches) in the city or other larger area;

L - total length of streets and roads in the city or other larger area;

- $\quad \mathrm{dP}(\mathrm{i})$ - deviation of the number of enterprises in a given location from the city average, calculated as follows: $\mathrm{dP}=\left(\mathrm{n}(\mathrm{i})^{*} \mathrm{~A}\right) /(\mathrm{a}(\mathrm{i}) * \mathrm{~N})$, where:

i - the location;

n(i) - number of the enterprises within i;

a(i) - number of premises (buildings) within i;

$\mathrm{N}$ - total number of the enterprises (of given branches) in the city or other larger area;

A - total number of premises (of given types) in the city or other larger area.

\section{Zagorodny Avenue}

The site adjoining the first section of Zagorodny Avenue (from Vladimirskaya Square to Zvenigorodskaya Street) had the highest concentration of the tertiary sector enterprises in the city. The average number of enterprises per building at this site (dP) was 6 times higher than the city average and is 3.5 times higher than the same index for the historical city centre. The number of enterprises per 100 metres exceeded the same index for the city (45 times) and for the historical centre ( 8.5 times).

The following retail and services branches were present on the site (per cent of the total number of the tertiary sector enterprises within the site): ${ }^{3}$

Foodstuffs

Audio, video and domestic appliances 
3rd order catering (bars, cafes)

Consumer service, repair shops, public utilities

Clothing

Consumer goods trade (wide assortment)

Administration

Tourist services

Legal services

Obviously, the site specialized in audio and video appliances services and trade. More than half of these enterprises were concentrated in the section of Zagorodny Avenue between Vladimirskaya Square and Lomonosova Street ('Five corners'). During the Soviet period, only one shop from this branch was present (Zagorodny Pr. 11). Nowadays, there are four at the same address. The former Soviet shop is now the biggest ('Eridan'). Most of the managers and owners of the shops find this location very satisfactory because of its prestige and the amount of passing trade.

These declared advantages of the site were borne out by the facts: Zagorodny Avenue was second after Nevsky Avenue in terms of the automobile and public transport traffic intensity. The number of pedestrians on Zagorodny Avenue was three times higher than the average indexes for the city. The high level of passing trade for the site is determined greatly by its macro-location: it is close to Nevsky Avenue, and the metro stations 'Vladimirskaya' and 'Dostoevskaya' are easily accessible by foot. One can feel the prestige of the site having observed the great number of cars parked along Zagorodny Avenue and nearby streets. Expensive foreign cars made up about 20 per cent of them. Furthermore, there were many expensive and elite boutiques, dressmakers' and global brand names. Significantly, rent levels on the real estate market for premises located on the nearest noisy streets (Rubinshteina street, Bolshaya Morskaya street) are traditionally high. These sites are very popular residential locations among wealthy citizens of St Petersburg (and many buildings are also used by the city authorities). There is an extreme concentration of highclass and reconstructed housing in the area.

It was typical for many respondents to mention the high density of enterprises from the same branch as one of the advantages of the site. According to the respondents, this concentration increased the amount of choice and attracted additional potential customers, which was especially advantageous for small shops. These were able to save money on advertising due to the pull of their brand-name neighbours, and entice customers with lower prices. In general, all the respondents found their location successful, despite some negative factors, such as high rent and the lack of suitable trade premises.

The high density of food stores was not a specific feature of the area. As has been explained in previous chapters, food stores have a pattern of 
local distribution, and their quantity is usually directly proportional to an area's population and the amount of workplaces. Most of the shops in the city centre have been there since Soviet times, although their total number has decreased by about 25 per cent. Thus, as will become obvious further on, in almost all areas observed, food shops head the list of leading branches, acting as a sort of a background for complex-building processes.

The high density of relatively high-standard public catering enterprises - cafes, restaurants, including fast food - is also worth attention. Most of them had only recently appeared at the time of our survey. It is noticeable that public catering enterprises, as well as food stores, ranked second or the third in the list of the leading branches in almost all zones of commercial activity. They form a kind of business infrastructure and, unlike the food stores, changed not only in quality (new trade and public catering types: 24 hours, fast food, etc.) but in their number as well. The reason for the increase of public catering enterprises in the city centre was the increase in customers in the other (leading) branches (in this case audio and video appliances shops).

The increased number of clothing shops, with expensive boutiques and well-known jeans shops dominating, may be explained by their orientation towards the buyers of audio and video appliances. Customers of both branches usually belong to the same social group: solvent young men with certain habits and lifestyle. In order to save time, these customers might combine the purchase of a car radio from the 'Pioneer' shop with clothes shopping at 'Dominico's boutique' and dinner at 'Mollie's Irish bar' all in one trip.

The large number of centre-typical branches such as legal and tourist services in the area is of no surprise considering its central location.

In summary, the area itself is very favourable for trade development, and was so even in Soviet times. It is a famous district with good transport accessibility, intensive traffic, high building density, a great number of workplaces, nearby metro stations, and as a result, an extremely high number of pedestrians - potential customers. These advantages have been used since the mid-1990s. The branch that started to develop first was the area's particular specialization - audio and video appliances, a trade that had been hardly appealing in the Soviet times. Obviously, the development of this branch was determined not only by the presence of a huge old shop but by a very active 'boom' in the development of the branch itself that now offered new types of products for Russian consumers. The emergence of the first specialized shops and their advertising strategies attracted additional customers to the area. Gradually, the area gained an image as the centre for the audio and video appliance trade in the city. This led in turn to the emergence of small shops, service centres and shops with accompanying goods (audio and video tapes, CDs, etc.) that rode 'piggy back' on the success of the huge Soviet era shop. Many wellknown chains (such as Technoshock) found it useful to establish a branch 
in the Zagorodny Avenue area. At the same time, branches of the retail and trade sector, primarily oriented towards the customers of these audio and video appliance stores, started growing. These include fashionable clothing shops and good standard public catering businesses. Following the general development of business activity in the area, CBD-building (central business district) tendencies are intensifying: buildings are being reconstructed as business centres and elite residences, and branches of the tertiary sector are developing that have a city-wide clientele and are typical of the city centre. All of these processes are accompanied by strong demand and competition in the market for business locations.

\section{Bolshaya Morskaya Street}

The area around Bolshaya Morskaya Street from Nevsky Avenue up to Isaakievskaya Square has been considered a respectable commercial district of the city since pre-revolutionary times. At the time of our survey, there were no branches aimed at mass consumption. Generally, this can be explained by the area's remoteness from the metro and rather low levels of passing trade. The branch composition of the area was rather specific:

$\begin{array}{lr}\text { Foodstuffs } & 10 \\ \text { 3rd order catering (bars, cafes) } & 9 \\ \text { Casinos, night clubs, cinemas } & 8 \\ \text { Clothing } & 8 \\ \text { Telecommunication services and equipment } & 7 \\ \text { Aviation services } & 7 \\ \text { Consumer service, repair shops, public utilities } & 5 \\ \text { 4th order catering (restaurants) } & 5 \\ \text { Jewellery and antique trade } & 5 \\ \text { Tourist services } & 5 \\ \text { 1st order catering (snack bars, bistros) } & 5 \\ \text { Educational establishments } & 3\end{array}$

Without a doubt, Bolshaya Morskaya Street was the largest centre for telecommunication services in the city. The reason lies with the historical location of communication enterprises in the area. There one could find the central office of the St Petersburg telephone network company (Bolshaya Morskaya Street, No. 24), the office of the St Petersburg long-distance and international telephone company (Bolshaya Morskaya Street, 3/5), the City Telephone centre (Bolshaya Morskaya Street, No. 28) and the St Petersburg Telecommunication University after Bonch-Bruevich (Bolshaya Morskaya Street, No. 16). In 1991, the first cellular phone operator in St Petersburg, Delta Telecom, opened an office, shop and service department in the premises of the St Petersburg telephone network. Later, the Telecommunication University became the basis for a training centre 


\section{0}

and an Alcatel office, as well as other commercial enterprises closely connected with these telecommunication companies. Naturally, many private companies - mobile phone dealerships and telecommunication equipment providers - also located in this area. Territorial cooperation both within the branch and with different enterprises also emerged here. This is because telecommunication companies are not oriented towards certain specific branches but towards offices with high-order functions, regardless of the industrial branch.

The idea of elite and prestige allocation is very important for Bolshaya Morskaya Street. For this reason, the offices of international airlines, antique and jewellery shops, globally branded clothing shops, casinos and night clubs located there, despite the very high rent levels and deficiencies of the premises. Even public catering was represented by the best brands and elite restaurants.

We can state that the traditional specialization and prestige of the area became the determining factor in territorial complex building at Bolshaya Morskaya Street.

\section{Metro station Mayakovskaya area}

This area, especially the section of Nevsky Avenue from Liteiny Avenue up to Vosstaniya Square, had the maximum indexes of tertiary sector density for St Petersburg: $(\mathrm{d}(\mathrm{L})=51$ for the city and 9.5 for the centre, $\mathrm{d}(\mathrm{P})=11$ for the city and 6 for the centre). It is possible to state that the commercial centre of the city is located here. The leading role is played by Nevsky Avenue, where the traffic and the number of pedestrians were two times greater than those in any other street in the city. The fact that this particular area has become the city centre is explained, above all, by the proximity to the main public transport junctions: the metro stations Mayakovskaya and Vosstania Square and the Moscow railway station and major city highways:

$\begin{array}{ll}\text { Foodstuffs } & 9 \\ \text { 3rd order catering (bars, cafes) } & 6 \\ \text { Administration } & 6 \\ \text { Clothing } & 6 \\ \text { Consumer services, repair shops, public utilities } & 5 \\ \text { Tourist services } & 4 \\ \text { Cultural societies } & 4 \\ \text { Consumer goods trade (wide assortment) } & 3 \\ \text { Audio, video and domestic appliances trade } & 3 \\ \text { Shoe trade } & 3\end{array}$

The branches present in the Mayakovskaya area indicate the area's orientation towards public mass consumption. Almost all tertiary sector branches 
are well represented there. However, the area is specialized in various branches of the retail trade, public catering and consumer services.

The most prominent factor of the area is the high level of passing trade. The maximum tertiary sector density, building reconstruction, the establishment of business centres and the displacement of residential functions are very noticeable along the streets with maximum traffic intensity indexes: Nevsky Avenue, Vladimirsky Avenue, Ligovsky Avenue and Marata Street. Besides the levels of passing trade, the extremely high density of tertiary sector enterprises can be accounted for by historical factors. Before the October Revolution, all the main streets of the area had been leading commercial centres in the city. The area retained this function throughout the Soviet period as well. Nowadays, the historically present capacities of the Mayakovskaya area are being developed. Since the 1980s, many old residential buildings have been turned into business premises.

It is possible to find some smaller complexes within the area, where complex building is determined by the factor of territorial cooperation, for example the concentration of shoe shops at Vladimirsky Avenue.

So, one can state that historical factors account for territorial complex building here, which took a course determined by the advantageous locational factors present at this site, primarily the high level of passing trade.

\section{Voznesenski Avenue 46}

The section of Voznesenski Avenue from Sadovaya Street up to Fontanka Embankment is a unique example of a territorial complex within the tertiary sector. Since the autumn of 1996, more than 10 elite retail and services businesses have located on the ground floor of this student hall of residence, a former clothing factory with a facade length of just under 300 metres. The managers of these businesses state that their enterprises - an expensive night club, furniture shops, car showroom, fashionable clothes shop, etc. - are elite because they are marketed as very expensive and exclusive shops (clubs or showrooms) for very wealthy customers. Almost all are oriented towards customers who come specifically to this location, having seen the advertisements. So all the companies attempt to provide a very high quality service, and are doing some joint advertising.

All managers found the location inconvenient: insufficient passing trade, no parking, and poor transport accessibility. But no one would like to move out because they consider that this is compensated for by the main advantages of the site: good neighbours, good premises and the prestige of the site. The manager of a recently opened fashionable clothing shop shared this opinion; however, the director of a former Soviet food store, serving local residents, found the location very unsatisfactory for his business. 


\title{
7 Post-transformation urban space
}

\author{
The results of spatial saturation \\ and the spatial organization of \\ new business forms
}

We have identified three major differences between the processes that govern the spatial organization of the retail trade and services in St Petersburg during the post-transformation stage of development, and those of the transformation stage. We consider these processes to have a pronounced impact on business location. First, if under transformation, the process of saturating consumer demand for merchandise shapes a new spatial pattern of location for the retail trade and services, the post-transformation period is marked by the end of the saturation process and the launching of attempts to recast business actors under conditions of generally saturated demand. Second, the structure of demand and the related shopping models are diversifying and becoming very different from those of the transformation stage. Third, the emerging post-transformational business forms act upon different locational preferences. We deal with these three aspects in some detail below.

\section{The results of spatial saturation}

When we say that the demand for consumer goods has been satisfied in St Petersburg, does this mean that the development of retail trade and services there has come to an end? Obviously, this is not the case. So, what, then, does the end of spatial saturation mean? Before answering this question, let us first outline some developments that we believe should be regarded as resulting from the process of spatial saturation, whether or not it has reached completion. Spatial saturation, which constituted the major mechanism of the distribution of the retail trade and services under transformation, has had at least five major outcomes.

First, consumer demand for access to the major groups of merchandise has been satisfied, in general. St Petersburg has reached the stage of a 'consumption society'. The increase over time of turnover figures for the retail trade partly supports this claim (Table 7.1).

Further arguments are supplied by other economic indicators, relating primarily to the growth of competition within the retail and services industry, a trend that is visible throughout Russia (Figure 7.1). 
Table 7.1 Dynamics of the retail trade turnover in St Petersburg, January-July

\begin{tabular}{ll}
\hline Year & $\begin{array}{l}\text { Turnover, } \\
\text { billion roubles }\end{array}$ \\
\hline 1998 & 20.8 \\
1999 & 32.0 \\
2000 & 44.4 \\
2001 & 61.6 \\
\hline
\end{tabular}

Source: Delovoy Peterburg, 22 October 2001.

By 2002, the rate of growth of retail turnover had slowed considerably, and at the same time the average profitability of retail trade in St Petersburg dropped substantially, reaching only about 5 per cent according to the official statistics, while six years before it had been 10 per cent. This tendency had been apparent for several years already - in 1999 the average annual increase in overall income for the 16 biggest retailers, which have occupied the same locations since socialist times, was 154 per cent, while in 2000 it fell to 120 per cent. (Delovoy Peterburg, 26 February 2002). Expenditure on advertising by three surveyed hypermarket chains increased by $20-40$ per cent in 2001 , which could be interpreted as a consequence of tightening competition (Delovoy Peterburg, 22 October 2001).

Second, the amount of retail and office space has multiplied. In 2001, the total amount of trading space reached 3.3 million square metres.

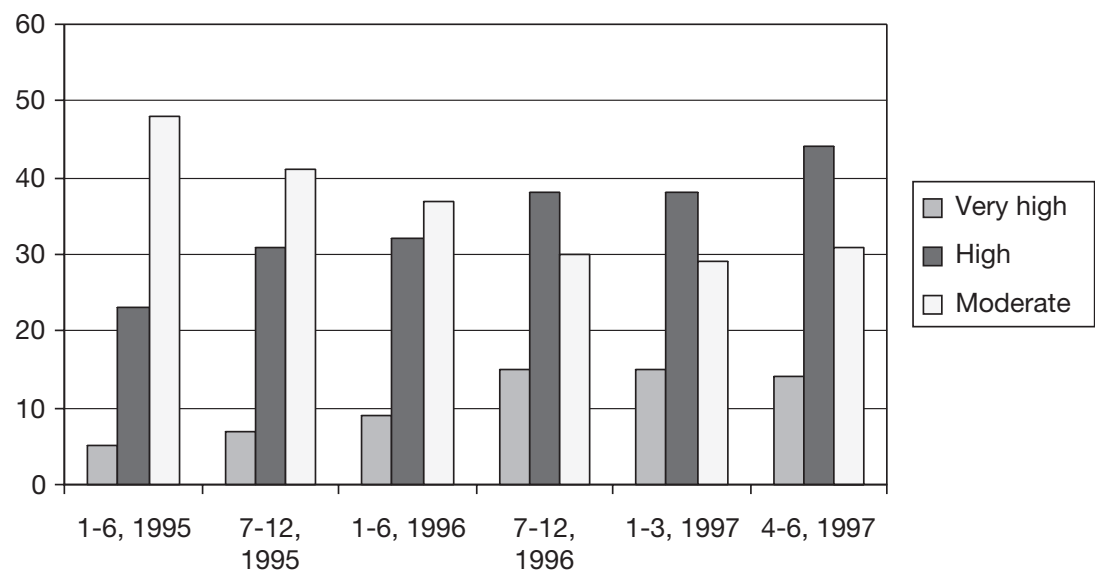

Figure 7.1 Estimated competitiveness of retail trade companies: percentage of surveyed companies for the months of the respective years

Source: Government of Russian Federation Centre for Economic Situation (Finansovye Izvestia, 8 August 1997): the survey involved about 1,600 interviews with retailers in 16 Russian regions. 
In St Petersburg, there were only 0.15 square metres of fixed trading space per capita in 1994, but by 2001 this figure had increased to 0.73 square metres per capita (Delovoy Peterburg, 22 October 2001). This is still lower than levels in Western cities, but weighted against the amount of consumer demand it looks quite comparable.

Third, the volume of turnover of the retail market in St Petersburg increased to US\$4 billion per year, ${ }^{1}$ which makes St Petersburg the second largest market in Russia (Delovoy Peterburg, October 18, 2001). On the measure of efficiency of trading space, ${ }^{2}$ major traders now come close to Western averages. Most of the big traders have an annual turnover of US $\$ 3,000-3,500$ per square metre, the market leaders such as the 'Pulkovski' or 'Severnyi' supermarkets reach US\$6,000-8,000 per square metre (Delovoy Peterburg, 26 February 2002). This means that investment in the St Petersburg retail market has become a much more interesting economic prospect for international capital.

Fourth, the process of spatial saturation has resulted in distinct social and spatial stratification of the retail and office space markets. Facilities and locations have emerged that target customers from particular socioeconomic groups (see, for example, Rudolph, 2001).

Fifth, the process of spatial saturation has produced a pattern of spatial distribution for retail and services that is completely different from that of the socialist era, and which has stabilized as the underlying pattern for further spatial development. We have described this pattern in previous chapters.

So, by the end of the process of spatial saturation we understand the fact that the primary concern of business actors no longer lies with the provision of sufficient quantities of a particular merchandise to satisfy consumer demand. Furthermore, the primary reasons for the choice of business locations no longer relate to the desire to explore new territorial markets within the city. The new stage of business competition is primarily based upon matters of quality and specialization, as well as on the redistribution of existing consumers rather than the attraction of new ones. The choice of business location in the new post-transformation stage tends to serve these very tasks, which are closely related to changes in the structure of demand.

\section{The new demand structure and related shopping models}

The post-transformation stage of the city's development is marked by the existence of greater social stratification in St Petersburg. ${ }^{3}$ According to the results of sociological monitoring, the income differential has increased threefold between 1989 and 1999 (Table 7.2). According to this survey, the income of the wealthiest 10 per cent of households in St Petersburg in November 1999 was 12 times that of the poorest 10 per cent of households. ${ }^{4}$ This ratio fluctuated in the period 1998-99 at between 10 and 12 times. 
Table 7.2 Income differential between the wealthiest and poorest sections of the population in St Petersburg, 1989-99

\begin{tabular}{llc}
\hline & $\begin{array}{l}\text { 10\% of the } \\
\text { poorest }\end{array}$ & $\begin{array}{l}10 \% \text { of the } \\
\text { wealthiest }\end{array}$ \\
\hline 1989, July & 1 & 4.1 \\
1992, April & 1 & 5.4 \\
1992, November & 1 & 8.8 \\
1993, October & 1 & 12.3 \\
1994, October & 1 & 11.0 \\
1995, November & 1 & 10.0 \\
1996, March & 1 & 13.2 \\
1997, April & 1 & 8.0 \\
1998, January & 1 & 8.8 \\
1998, October & 1 & 10.9 \\
1999, November & 1 & 12.2 \\
\hline
\end{tabular}

Source: Compiled from Protasenko, Revtova and Fadeeva, 2000.

This stratification has led to substantial shifts in the structure of consumer demand. In such an economically diverse society consumers from different social strata will obviously have different requirements for goods and services. The emerging business forms and spatial structures of the retail and services industry tend to serve this variety. On the basis of this social stratification, new types of consumer behaviour have emerged, of which the major ones are outlined briefly here:

- During the last few years the number of consumers with an above average income has increased. According to some experts, the number of consumers whose monthly income exceeds $\$ 300$ has reached a level that is sufficient to attract international capital and the related business structures (Delovoy Peterburg, 26 February 2002). These people normally have a car and tend to exhibit the main features of Western middle-class shopping behaviour. Above all, this means shopping by car once or twice a week, preferably in one location, for everyday commodities and making longer trips by car to shop for long-term consumer goods. The implementation of such a model in St Petersburg has long been restricted by the low levels of car ownership, as described elsewhere. Nowadays a private car is available to a majority of households in St Petersburg (in 2001: 172 private cars per 1,000 persons, in 1990: 56). When this limitation was generally overcome and the number of the customers with an appropriate income reached a suitable level, business began to offer the respective spatial structures - large-scale shopping and service facilities oriented exclusively towards car-owning households. We have termed such consumer behaviour 'post-transformation' type shopping. The majority of the 
city's population probably combines this type of shopping with the next type.

- 'Transformation' type shopping - this describes a pattern of behaviour whereby people tend to shop along their daily routes and/or buy most commodities in the local neighbourhood, normally within walking distance from their home. This type of shopping behaviour has been discussed already in Chapter 4 . The significant feature of this type of shopping is that it allows people with limited time to purchase goods, albeit at higher prices, without having to spend time travelling to a location where the goods may be available at lower prices.

- The 'new poor' have no car and look for goods at the lowest possible prices. They tend to travel to rather remote locations specifically to find lower prices. This group includes the majority of the older population and some social welfare dependent groups. They use public transport or walk long distances to reach the required location markets, trade zones and social welfare facilities.

This new stratification of consumer behaviour is obviously related to the emergence of new business forms and their spatial structures. Each type of consumption model produced a set of spatial requirements for the location of the retail and services business, and was followed by the creation of spatial business systems with relatively independent marketing strategies.

\section{Post-transformational business forms and their locational preferences}

Post-transformation was marked by the introduction of new business forms in retail trade and services. Most of these represent the implementation of international business forms, and some are associated with international investment. All of them aim to attract a clientele from the broadest possible territory and thus influence the spatial structure of the whole city. This has produced both the new vertical spatial structures and territorial complexes. And, of course, they reflect the latest stratification of consumer demand, targeting different social groups. What are these new business forms? Whom do they target? What role do they play in the recasting of the retail and services business in the city? What principles do their locational preferences follow and what characterizes the spatial structures, introduced by them? These are the questions addressed by us in our discussion of the newly emerged business forms. Among the most important ones, discounters, hypermarkets, cash-and-carry-type facilities, multifunctional complexes, different types of chains, social welfare oriented establishments and networks, and business centres should be mentioned. These forms are somewhat related to the respective Western ones, so our 
discussion focuses on the specific features attributed to them in the Russian and St Petersburg context.

According to the St Petersburg Administration, there were about 9,000 permanent trading facilities, about 300 markets and open-air trading zones in the city in 2001. Of the 3.3 million square metres of trading space, only 150,000 square metres was deemed to be of international standard by experts from the group Colliers International (Delovoy Peterburg, 18 October 2001). The same experts also date the start of major restructuring in the Moscow retail trade to 1999, when the numerous trading zones and markets leasing very small trading spaces to private traders began to be steadily replaced by the large multifunctional complexes merging trade with entertainment and services, and by Western-type hypermarkets aiming at attracting global brands as 'anchor' operators. Since that time, the network of such facilities in Moscow has become well developed, although its density had reached only 12-15 per cent of the average level for Western European cities (Delovoy Peterburg, 26 February 2002). Some of the first international owners of these hypermarket chains were the Swedish company IKEA, followed by Metro AG, as well as the Turkish Ramenka concern. Other large international retail operators started to enter the Moscow market only after the appearance of Metro AG, the world's third largest retailer, which became interested in Russia after the manufacturers of many international brands had built production sites there Delovoy Peterburg, 26 February 2002). The Moscow authorities plan to have built 300 trading centres of about 6.3 million square metres by 2020 . The experts from Colliers International expected that in St Petersburg the same development trend should become very apparent by 2002-03 (Delovoy Peterburg, 18 October 2001). Is this so in reality?

\section{Hypermarkets and cash-and-carry type facilities}

The largest facilities, in terms of trading space, emerged in St Petersburg several years ago. The most promoted names were Maksidom, selling construction and household goods, and PLATO, specializing in clothes. Cashand-carry type facilities, which combined some wholesale activity with retailing, were represented by several facilities under the Uniland and Megamart brands among others. Most of these operators were based on Russian capital and were not included in bigger international structures. ${ }^{5}$ By 2000, they had started to play an important role in some branches, construction and household goods being among the first.

Traditional socialist-type supermarkets, most of which were built to very similar plans, offered 1,000-1,500 square metres of trading space. Major old department stores, such as the pre-revolutionary Gostinyi Dvor, DLT or Passage in the very centre of the city, have 5,000-13,000 square metres, split into rather small sections. New hypermarkets in St Petersburg normally tend to have $8,000-30,000$ square metres of trading space, which 


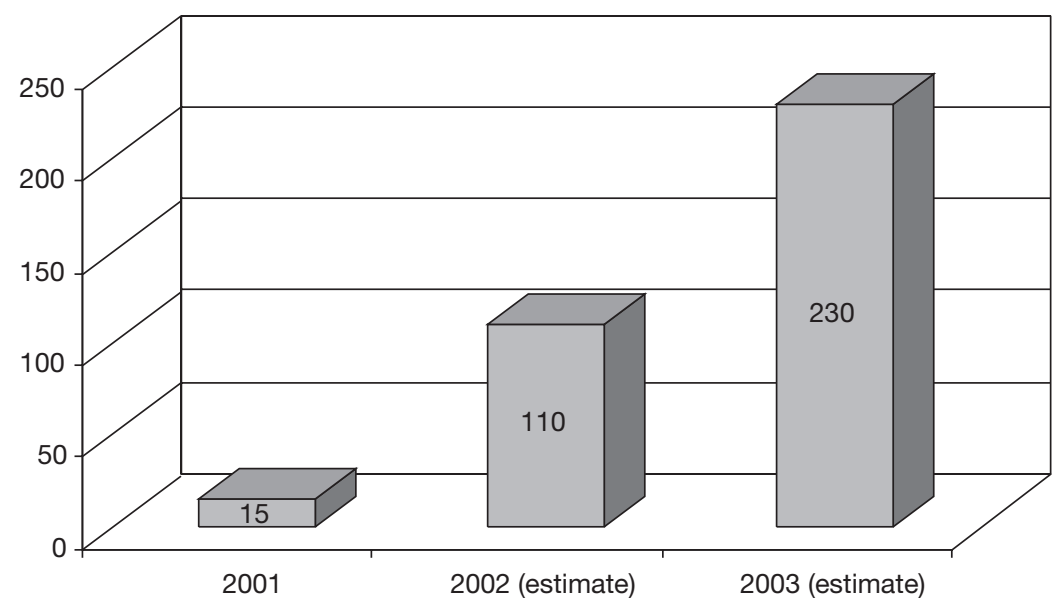

Figure 7.2 Total trading space of hypermarkets in St Petersburg, in thousand square metres

Source: Delovoy Peterburg, 22 October 2001.

can be used much more flexibly. Estimates of the development of the hypermarkets in St Petersburg are shown on the Figure 7.2.

Russia's first huge cash-and-carry market, built to international standards, was called Megamart and opened in St Petersburg in 1998. It was built by the Uniland company, which already owned a chain of minor cash-and-carry facilities in the city under the Uniland brand name. The main reason for establishing Megamart alongside the existing Uniland chain was to attract further wholesale customers in addition to the retail customers, who constituted the majority of Uniland clients. The Uniland company initially invested US\$5 million in this facility, and planned to expand in the future to build more such cash-and-carry markets in St Petersburg, as well as elsewhere in Russia. This project was successful, and St Petersburg now hosts a chain of Megamarts, with stores in every major part of the city. The company has stated that it aims to locate its stores in such a way that the nearest Megamart is within a 30-minute drive of every resident (Sankt-Peterburgskie Vedomosti, 31 March 1998).

Most of the first hypermarkets and cash-and-carry type stores used local or Russian starting capital and management. Because of that, they had problems attracting big international brands as 'anchor' operators and resorted to other marketing strategies. Since 2001, international and large Moscow retail operators have started to intervene rather actively in the St Petersburg market. Some of them, such as the Moscow supermarket chain Perekrestok, became 'anchor' operators in existing big hypermarket chains in St Petersburg. Others, such as Metro AG, preferred to build their own facilities. Experts expect that the entry of Metro AG into the St Petersburg 
market will produce an effect similar to that in Moscow where it heralded serious restructuring of the retail trade, as well as the attraction of more international capital and brands to the local market (Delovoy Peterburg, 23 November 2001).

Metro AG invested about US\$50 million in opening two hypermarkets in St Petersburg. They are practically identical to those in Moscow, having 10,000 square metres of trading space and car parking for 1,000 cars, and will carry 15,000 lines of merchandise and employ 400 staff each. Each facility requires a site of no less than 4-6.5 hectares. Interestingly enough, Metro AG initially planned to follow its traditional locational rules, and place their hypermarkets by major highways at the edge of the city, thus targeting exclusively those who practice the 'post-transformation' shopping model (Delovoy Peterburg, 23 November 2001). However, they later decided to locate one store in a large, new, rapidly developing residential area with good connections to the metro and the public transport network. This location has attracted several other large retailers (Delovoy Peterburg, 8 April 2002). Such a location decision is probably related to the fact that large retailers are still concerned about the extent to which the 'post-transformation' type shopping model prevails in St Petersburg, and so tend to secure themselves by locating facilities at sites that are also accessible by public transport.

Hypermarkets follow several locational practices. The first is conventional practice and was imported along with Western capital. One of the first large, foreign-owned retail complexes was built by Finnish investors to accommodate a big supermarket and a furniture store. The Super-Siwa complex was opened in the early 1990s on the site of a socialist-type supermarket at the very edge of the city, close to the motorway to Helsinki, in an area with almost no public transport connections. It accommodated almost exclusively Finnish retailers from both the food and furniture trade, and its target group was not so much local 'new rich' consumers, but rather the numerous Scandinavian tourists and businessmen entering the city (Figure 7.3).

Nowadays, there is a McDonald's restaurant right by the Super-Siwa complex. But of much greater interest is the fact that in 2001, one of the city's largest cash-and-carry chains, Lenta, opened a hypermarket just across the road from Super-Siwa, which may force the Super-Siwa managers to rethink their strategy (Figure 7.4). ${ }^{6}$

This location has also attracted several other brand-name operators, such as Volvo, which has servicing and car sales facilities there. In the case of this location, we witness the conventional Western practice of locating large stores by major highways on the outskirts of the city. The promotion of the location by one operator led to the creation of a new type of territorial complex that includes several large stores orientated almost exclusively at those with access to a car. ${ }^{7}$ 


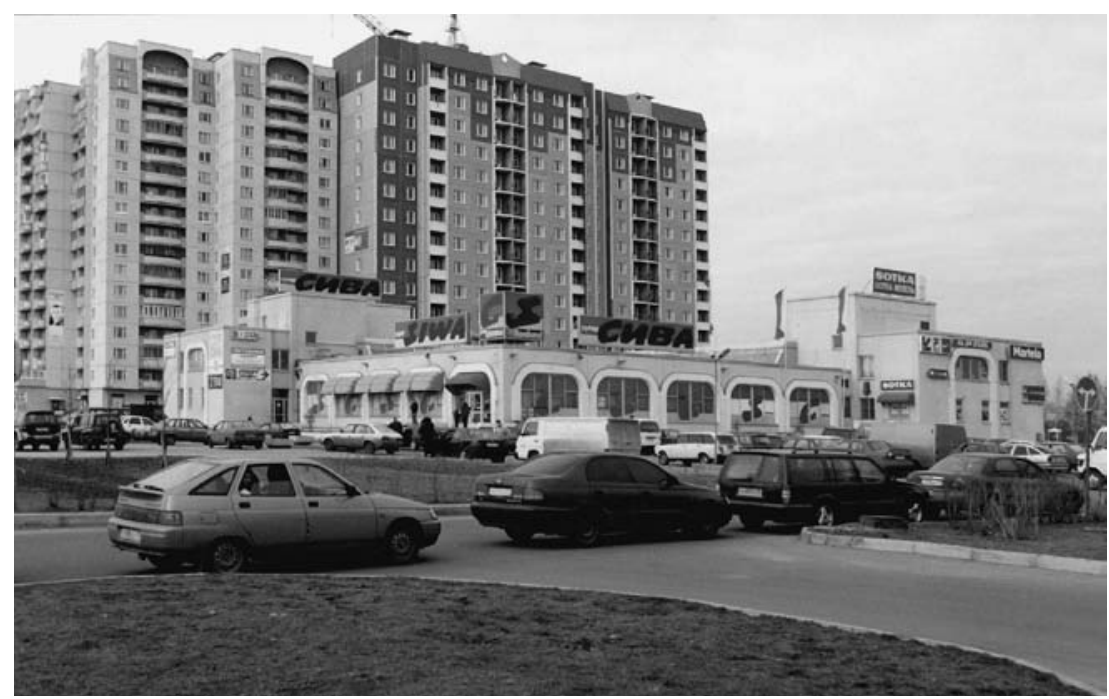

Figure 7.3 Super-Siwa complex, 2002

Source: Photo by F. Krenev.

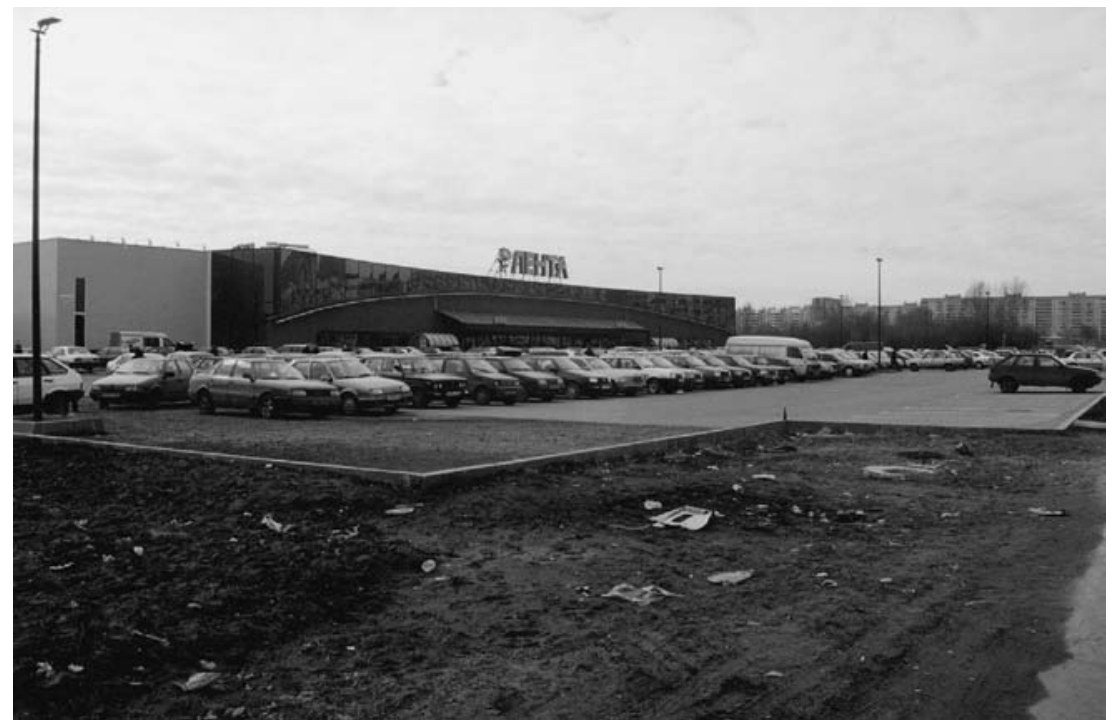

Figure 7.4 Lenta hypermarket, 2002

Source: Photo by F. Krenev. 
Another practice concerning the location of hypermarkets has been mentioned already. This is the tendency of retailers to seek a location that combines public transport accessibility with proximity to major highways. The most attractive locations for this practice are areas around metro stations in the largest residential areas. Normally, such sites can provide sufficient space for the hypermarket building and parking, as well as guaranteeing potential customers from the daily flow of commuters using the transportation node. One of the latest examples of this is located in an area of new residential development adjacent to a new metro station, Staraya Derevnya, as well as the railway station. There, three hypermarkets chains have simultaneously opened stores in redeveloped socialist industrial buildings or newly built premises. These are the Uniland and Megamart cashand-carry hypermarkets, and the new furniture retailer Mebel-City. ${ }^{8}$ Numerous small retailers have also been attracted to this location by the vast amounts of space formerly occupied by an old socialist era industrial enterprise, which has produced an interesting combination of transformation and post-transformation medium in one location (Figures 7.5 and 7.6). In addition to attracting these fixed-space retail facilities, this area is host to the standard kiosks, market, trading zone and pavilion complex in direct proximity to the metro station.

The third trend in hypermarket location is the redevelopment of old industrial facilities all around the city. The most actively sought-after locations are those in proximity to transportation nodes, as in the above case, and those in the inner industrial belt close to the city centre. The presence of an important transportation artery was a major contributory factor to the location of the large Svetlanovski complex in a building formerly used by the Svetlana industrial enterprise. Many retail trade and services operators, among them the German builder's merchant, Kaiser, chose to rent trading space from the large engineering works Kirovski Zavod (Kirov Factory), because of the nearby Kirovski Zavod metro station. The PLATO and Sampsonievski hypermarkets occupy former industrial sites very close to the city centre (Figure 7.7).

A fourth type of location practice sees hypermarkets emerging close to concentrations of car owners. One of the first Megamart cash-and-carry hypermarkets appeared at the Salova Street territorial complex described in Chapter 6, which is completely oriented towards car owners. Megamart occupies a location across the road from the major car parts market and offers parking for those attending the car parts market as well its own customers. Thus it became part of the Salova Street complex, transforming the nature of this complex. ${ }^{9}$

The introduction of hypermarket business form to St Petersburg has brought a new dimension to territorial complex building. The new, rapidly developing residential area in Primorski rayon in the north-western part of the city provides an interesting example of this. There, a huge new 


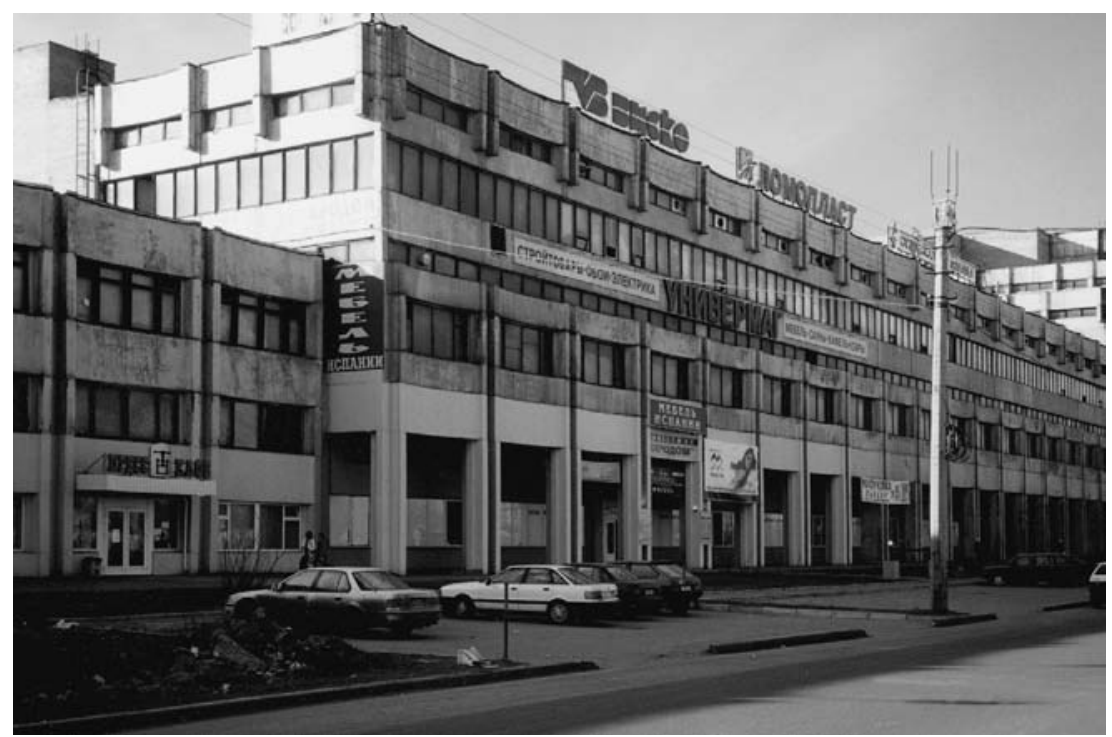

Figure 7.5 Transformation-type facilities: recycling industrial constructions from socialist times into trading space, Staraya Derevnya, 2002

Source: Photo by F. Krenev.

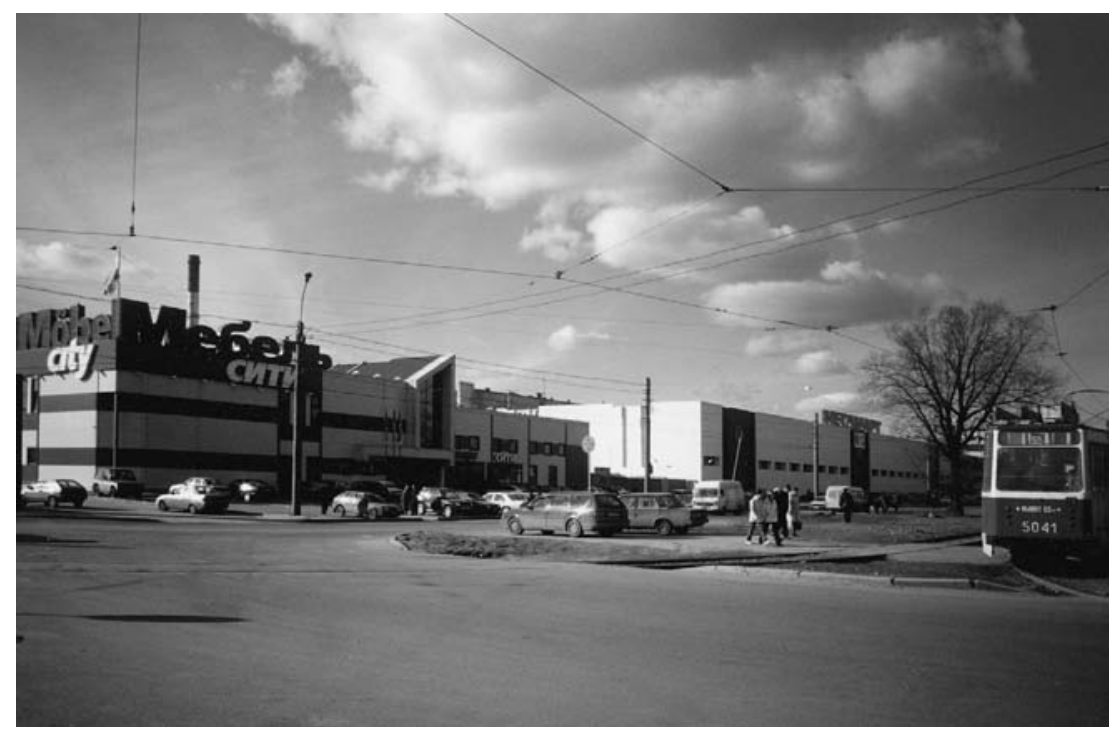

Figure 7.6 Post-transformation-type facilities: Mebel-City furniture retailer and Megamart cash-and-carry hypermarket, Staraya Derevnya, 2002

Source: Photo by F. Krenev. 


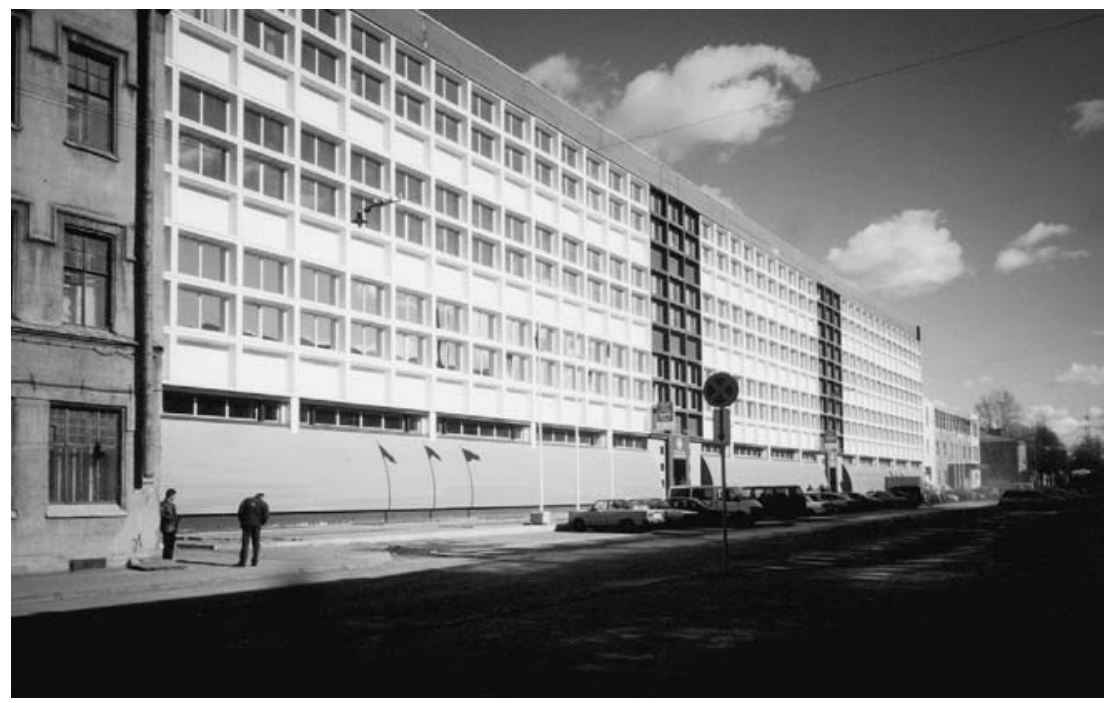

Figure 7.7 Sampsonievski hypermarket - post-transformational type of industrial buildings recycling

Source: Photo by F. Krenev.

housing development is planned, which is to be served by three metro stations. One of these is the Staraya Derevnya station, which we have already mentioned as a location for a hypermarket complex. In addition to this complex, however, at least five more hypermarkets and complexes are under construction in the triangle between the three metro stations, Plato, Maksidom and Metro being among them. This will be the largest concentration of largest-scale retail facilities in the city. Without doubt, this huge territory should, despite the considerable distances between the facilities, be treated as a new type of territorial complex. Such a complex cannot target the local customers exclusively, even in such a large residential area. It needs to attract a much broader or even city-wide clientele, practising 'post-transformation' shopping behaviour and looking to access the broadest possible range of services and shopping opportunities in the least time-consuming fashion.

In Figure 7.8 we show the distribution of major cash-and-carry and hypermarkets in the city according to the four major locational types that we have outlined here.

\section{Chains}

The chain was probably the first of the conventional Western retail trade and services forms to appear in the St Petersburg market. Although 


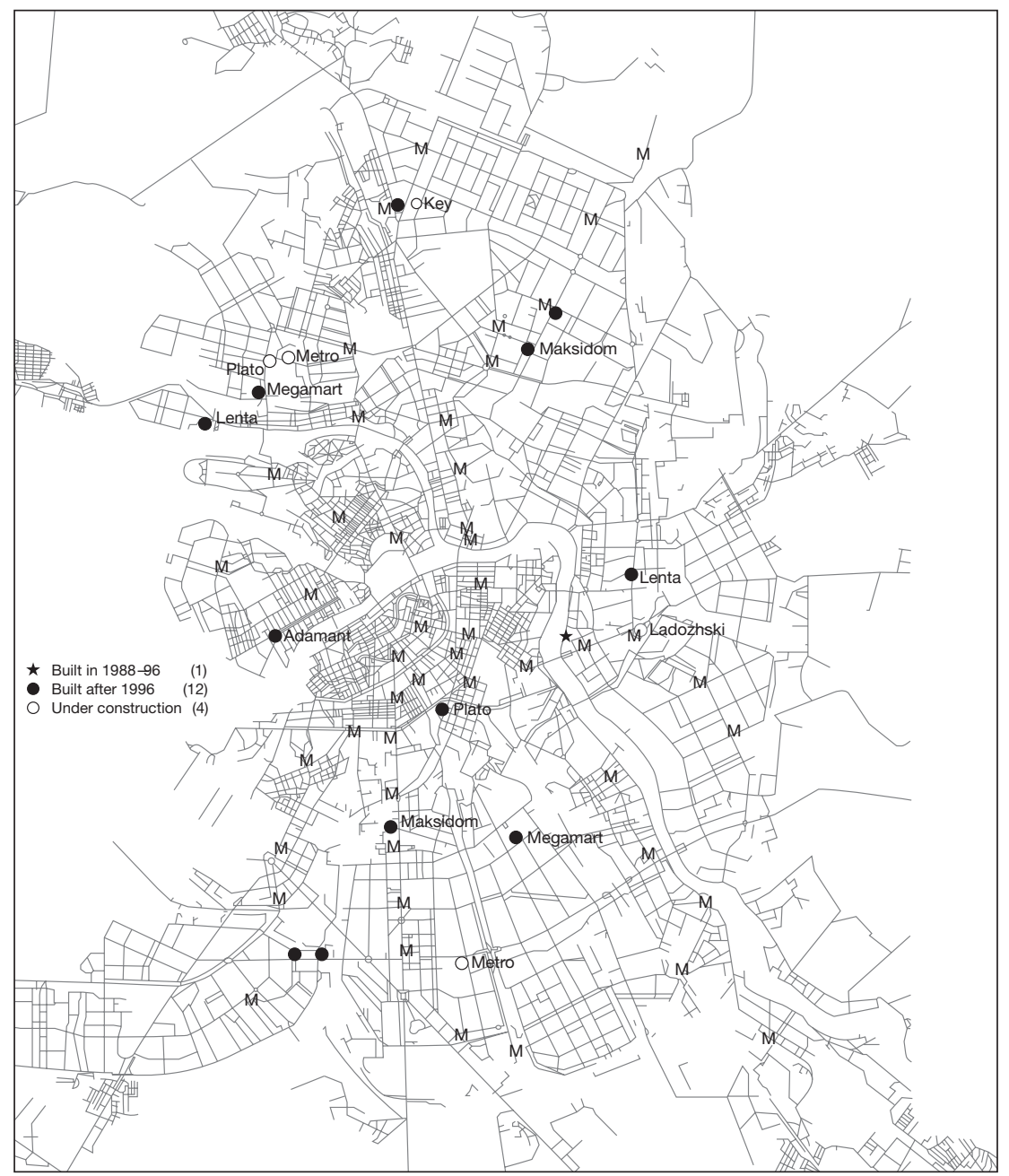

Figure 7.8 Location of hypermarkets, April 2002

Source: Authors' survey.

conventionally a chain consists of at least 6-7 outlets, the first retailers in St Petersburg to call themselves chains had just two or three. Chains are present on all scales of the retail business. The first branded retail chain in St Petersburg was probably a chain of Marlboro kiosks that appeared in the early 1990s (Papadopoulos and Axenov, 2002). Today we are witnessing the creation of hypermarket chains. Retail chains are numerous now: some are based on international capital, but the majority 
are local ventures. Chains appeared in many branches of both the retail trade and services, but apart from hypermarkets they do not yet constitute a significant force in the retail and services business. This is exemplified on the one hand by the fact that less than 5 per cent of food stores belong to chains, and on the other by the fact that the largest bakery chain in St Petersburg, 'Centralnye Bulochnye', has a total trading space of just over 13,000 square metres, which is about the average trading space of a single hypermarket (Delovoy Peterburg, 26 February, 2002). ${ }^{10}$ The development of chains in almost every branch of retail trade and services - e.g. the Union Group, a chain of 44 automobile servicing facilities, Computer Centre Key, a computer maintenance company with a city-wide presence, and the clothing chain owned by the Israeli manufacturer and retailer, SELA - is, nevertheless, one of the marks of the post-transformation stage and is associated with the introduction of a mass consumption model.

The pattern of distribution of the facilities belonging to chains is heavily dependent on their size and branch specialization. In general, they tend to follow the major locational priorities of their branch, as described in Chapter 5. It is important to note that although the distribution of the facilities of the post-transformational chains follows the same patterns as that of the individual facilities of the transformational stage, the latter could only influence the local market, whereas the former are able to shape the retail and services market of the city as a whole.

\section{Discounters}

This business form appeared in Russia in 1998 and was aimed at attracting the lower-income customers from the markets and open-air trading zones. Obviously, the economic crisis of 1998 was a factor that favoured the emergence of this form, but it was not the only reason. Although the first discounter stores opened in Moscow, one of the biggest discounter chains in Russia was started in St Petersburg. Russian discounter chains are very similar to those in the West. In some cases, such as the St Petersburg Pyatiorochka chain, they were started by 100 -per-cent foreign capital. Others were started by Russian managers who had observed the discounter business in the West, as in the case of Perekriostok, one of the first Moscow discounter chains, where managers of the company, which already owned a chain of supermarkets, decided to use the new business form after studying it in France. So it can be said that this business form has been 'fully imported'. The typical discounter store occupies an area of 400-600 square metres, which is $2-2.5$ times smaller than a standard supermarket but twice the size of an average food store. In Moscow, the average investment in a discounter store is US\$70,000-200,000, while for a supermarket it is \$2.5-4 million (Kommersant, 14 March 2001). ${ }^{11}$ The 


\section{6}

authorities in many Russian cities showed active support for this business form through tax breaks, etc.

According to experts, two types of discounter chains operate in Russia. The first is the classical discounter, where the same low-cost merchandise is sold in every store. Operating costs and investment in real estate are kept to a minimum and technical costs are minimized by the introduction of centralized supply and logistics. The St Petersburg Pyatiorochka chain is an example of a classical discounter. The second type represents a transitional form between a classical discounter and a more conventional supermarket, though providing cheaper merchandise than the latter. Such chains (sometimes called 'soft discounters') have larger stores with better interiors and offer a better service. One 'soft discounter' in St Peterburg is the Kopeika chain. This sort of discounter sometimes has a very similar appearance to a conventional supermarket, with some chains even adding certain expensive items, such as good-quality alcohol to their stock.

While theoretically, regular discounters compete primarily with the markets and open-air trading zones for customers, it appears that they have become increasingly interesting for another category of consumers as well - those practising 'transformation' type shopping, i.e. people who tend to shop in the stores and supermarkets located along their daily routes and in the proximity of their homes. They were attracted by the discounters because their facilities were located quite favourably in comparison to the markets - near transportation nodes or in the centre of large residential areas. Furthermore, the discounter chains have brought their standards closer to those of the retailers traditionally used by this group of customers, through the introduction of 'soft discounters'. Consequently, the regular supermarkets have felt competition from the discounters and tried to respond to this challenge: 24 regular supermarkets in St Petersburg have set up a new company that carries out the centralized wholesale purchase of merchandise to be sold via these supermarkets. While about 1,500 lines are common to stores in the classical discounter chain Pyatiorochka, there are only 700 items common to each store in this distribution network; this constitutes about 50-70 per cent of the total merchandise of a supermarket (Delovoy Peterburg, 2 February 2001).

The direction in which the discounter chains have developed and the related effects of that development on the market are grounded in the discounters' locational practice. Because they followed a similar locational policy to conventional food stores and supermarkets, they became the primary competitors not of the open-air markets but of these facilities.

Experts expect that classical discounters will become much more widespread if the open-air trading zones and markets are closed by administrative regulation in a similar manner to the kiosks (Kommersant, 14 March 2001). 


\section{Multifunctional complexes}

This business form is generally a complex of trade, service and entertainment facilities in different combinations offered by one owner/promoter in one building or location. Before St Petersburg has become home to any large Western shopping mall type of facilities, their functions were distributed among the multifunctional complexes, some of which come rather close to the shopping-mall format. These complexes serve customers with higher than average incomes who have begun to care about the quality of service and have additional money to spend on entertainment. Most such complexes are built by large local retailers. The combination of these functions is a relatively new tendency for St Petersburg - in socialist times, trade and entertainment were spatially separated. In the biggest department stores in the city centre, a small cafe was usually provided, but the quality of this could hardly be associated with entertainment. The first complexes of a high standard that could be called multifunctional were Balkanski and Aerodrom, opened in 1998 by the Adamant company near metro stations in large residential areas (Delovoy Peterburg, 26 February 2002). They combined large retail premises that accommodated numerous small operators with night clubs, casinos and amusement arcades, etc. These complexes were quite far from the Western standards that were first introduced with the creation in 2000-01 of the Bada-Boom and Baltiiski complexes. While the former was initially planned as an entertainment facility, the Baltiiski complex (built by the aforementioned Adamant) could probably be considered as the first to approach a Western-type shopping mall. It was conceived to serve the needs of customers with distinctly higher incomes, and includes 200 shops, a night club, cafes, a beauty centre, an exhibition area and some services. By 2003 a cinema was built there.

2002 is to be the year of the multifunctional complex 'boom'. At least 19 new multifunctional complexes ranging in size from 4,500 to 59,000 square metres were under construction then. One of the most prestigious projects is the Vladimirski Passage complex in the very centre of the city. It is located in a seven-storey historical building, the first five floors of which comprise an 18,000-square-metre shopping centre, with a 9,000square-metre hotel on the top two floors. The developer behind this project, which is worth US\$25 million, is one of the big St Petersburg retail companies (Delovoy Peterburg, 26 February 2002). Several other retailers who own large markets and trading zones targeting the lower income strata have also launched ambitious projects to build multifunctional complexes for the rich. This obviously involved a change in their business strategy as well as the way they organized retail space. The market place type of trade in which they were previously engaged was based on providing lowcost facilities that could host the maximum number of small retailers. 


\section{8}

While retail space in such facilities was split into kiosk-sized sections, the new complexes offer basic units of 20-40 square metres that can be combined to produce larger units. Furthermore, the external appearance and internal fittings of the building account for a significantly larger proportion of the total investment than in market-type facilities. The most popular entertainment facilities included in such complexes are bowling alleys, pool bars and halls, and venues for dancing. Some plan to include cinemas, concert halls and even aquariums (Delovoy Peterburg, 26 February 2002).

In a very noticeable trend, most of these complexes tend to be located near metro stations and other major public transportation nodes. The aforementioned Baltiiski complex, which is targeted at car owners, probably presents the only exception to this. This tendency means that multifunctional complexes generally follow the same locational strategy as the hypermarkets, trying to attract car owners as well as the users of public transport. In general, multifunctional complexes could be treated as a sort of preplanned territorial complex, built by one agent. This complex building philosophy should, no doubt, be attributed to the post-transformation type of spatial behaviour of retail trade and services.

Since the time when our research was completed in 2002 several facilities that could be considered Western-type shopping malls have emerged. As compared to multifunctional complexes, St Petersburg shopping malls offer bigger total trading space and car parking, the presence of an 'anchor' branded operator, bigger trading sections, the presence of a food court and large leisure facilities.

One of the examples of a shopping mall is Sennaya complex opened in 2003. More than US $\$ 30$ million was invested by a local retailing company in building in the city centre the complex of about 60,000 square metres and a capacity of about 25,000 customers daily turnout. It was initially planned that several anchor operators would be hosted there, among them Patterson food megamarket, an electronics chain facility and the biggest (in St Petersburg) department store of children's merchandise (1,600 square metres). The biggest bowling facility in St Petersburg (of about 4,500 square metres) and a food court are located there. There are 12,000 square metres of public space - halls, walking ground, stairs, etc. (www.sennaya.ru).

Locational strategy of the shopping malls is very similar to that of multifunctional complexes. Some of them are located in the city centre, some near metro stations at the outskirts of the city. 


\section{Social welfare oriented establishments and networks}

At the same time that the 'new rich' emerged, another new social strata appeared that could, in contrast, be called the 'new poor'. These are the people on the lowest incomes. The majority are pensioners and welfare dependent since according to a government declaration in 2002, planned increases in the average pension would only bring it closer to the amount defined as the minimal cost of living. The 'new poor' also include many employees of the state, municipal companies and social institutions - scientific, educational, medical, cultural, public and others, where salaries still do not exceed US\$70-120 a month. Most of the 'new poor' can afford only small amounts of the cheapest merchandise, very limited service and no commercial entertainment. The overriding policy aim of the authorities is to ensure that this large section of the population is able to use public transport. In St Petersburg, most public transport is still free for pensioners, so they are able to move around the city. ${ }^{12}$ The city administration and public organizations have developed several programmes to provide discounted or subsidized merchandise and services to the 'new poor'. These are networks of social welfare oriented stores, cafes and services. Most of these networks are fully or partly subsidized, so they can hardly be treated as an integrated part of the St Petersburg market, but such social welfare facilities deserve attention nonetheless, because they inevitably compete with the existing market facilities. As mentioned before, the absolute majority of this population strata looks for the cheapest shopping and service possibilities, which means that they constitute a major source of clientele for the remaining trading zones, markets and kiosks.

Of greater importance to our discussion, however, are new profit-based projects, aimed at the poorest sections of society. These represent new business forms introduced recently to attract consumers, who still primarily use markets and have not been attracted by the discounters. In late 2000-early 2001, St Petersburg became the testing ground for a unique and ambitious social and business experiment.

The Kolibry corporation, which includes major regional agricultural and industrial manufacturers of food and everyday consumer goods as well as the Petrovski bank, the major pensions operator in St Petersburg, founded a new company called SOS (an abbreviation of the Russian for the Union for Common Destiny, using Latin characters, though, to draw a parallel with the meaning of the international term). This was the first step in a project aimed at opening about 150 shops for the pensioners served by the Petrovski Bank, i.e. the majority of St Petersburg's 1.5 million pensioners. By 2002, this network had been almost fully established. These shops sell a wide variety of goods, supplied directly by the manufacturers involved in the project at manufacturer's prices. Thus, in the SOS stores, the additional costs of wholesalers and retailers are not passed on to the customer, making SOS merchandise the cheapest on the market. 
The Petrovski bank provided not only information and marketing support but also the unique financial service. SOS issued and distributed among Petrovski's client-pensioners special membership cards giving an access to the full service provided by SOS. It was planned that customers should be able to use their membership cards for electronic transactions and to receive credit. The Petrovski bank has since quit the project, and SOS has had to use other information and marketing resources - welfare databases, veterans', social and public organizations ( $R B K, 6$ September 2001). ${ }^{13}$

This was a 100-per-cent commercial project - the company rented all the real estate for its facilities either from the city or on the secondary real estate market, and received no preferential rents from the city. The project sought the lowest cost permanent facilities located in the residential areas with the oldest demographic structures, and rented 155 facilities of between 44 and 310 square metres (http://torg.spb.ru/2001/arch06/web. $\mathrm{html}$ ). Obviously the real estate thus chosen was in locations normally considered unfavourable for retail trade and services establishments. Although consumers could reach the facilities by foot or by public transport, they did not front on to busy streets, traffic or commuters flows.

So we can state that both social welfare-oriented establishments providing non-profit services and commercial companies with social welfareoriented objectives use the same spatial strategy. Neither use location and real estate advantages to attract customers; rather they seek locations that are generally accessible to their targeted group - whether it is the back yard located within walking distance of the large residential area or a site on the fringes of the inner industrial belt most accessible for a city-wide clientele (as in the case of hostels for the homeless). This locational behaviour is necessarily accompanied by an information or advertising campaign by the social welfare-oriented networks, whereby the major emphasis is on informing the target groups of the exact location of the respective facility. Like the other business forms described above, the social welfareoriented establishments and networks of the post-transformation stage tend to operate on the macro-scale and treat the city as a single business space.

\section{Business centres}

This is the only post-transformation business form that we deal with here that relates to business services. Business centres, a type of facility, in which office space is leased, appeared in substantial numbers during the transformation period. This was due to the abrupt growth in demand for office space from new businesses, coupled with the release of office space as a result of the decline of the large socialist industrial enterprises, research institutions and public centres. Some of the big office buildings that belonged to industrial enterprises and other institutions of the socialist era were converted into business centres and leased out to new businesses. 
Table 7.3 Average rent for office space in St Petersburg, 2000

\begin{tabular}{ll}
\hline Class & $\begin{array}{l}\text { Rent, } \\
\text { US\$ per sq } m \\
\text { p.a. }\end{array}$ \\
\hline A & $300-500$ \\
B & $200-400$ \\
C & $70-200$ \\
D & less than 70 \\
\hline
\end{tabular}

Source: Nedvizhimost Peterburga, 2000, p. 71.

In most cases there was little, if any, refurbishment of the building, and the owner provided almost no additional services or promotion. This type of office centre prevailed during the whole transformation period, which leads us to term them 'transformation'-type business centres. The post-transformation stage, which was marked by the active entry of international business into the St Petersburg economy, ushered in demand for office space that met international standards. The first Western companies to become established in St Petersburg, as well as large Russian companies did not locate their offices in 'transformation'-type business centres; instead they preferred to adapt other real estate to their own specifications or to rent space that they considered appropriate to their needs. In 1998-2000, the demand for international standard office space contributed to the emergence of corresponding facilities, and by 1999 demand for 'transformation'-type business centres had, according to expert opinion, begun to stagnate (Nedvizhimost Peterburga, 2000, p. 69). At the same time that the market started to offer office space of international standard, prices for office space became comparable with those in the world's largest cities (Table 7.3).

Class A business centres represent the highest standard, and are usually built and managed by Western companies, class $\mathrm{B}$ and $\mathrm{C}$ by local ones. The 'transformation'-type business centres are normally attributed to class C. In 2000, there were just four class A business centres, and this class constituted only 5 per cent of the office space market (Nedvizhimost Peterburga, 2000). However, by 2002 there were more than a dozen. Between 1999 and 2001 , class $C$ office space became the most desirable on the market and numerous business centres of such a standard appeared. All combine goodquality space, location and appearance with a range of services - guards, parking, communications, restaurants and cafes and even leisure facilities and services such as sauna, fitness centres, beauty salons, etc. Many business centres of all classes tend to include some retail space or multifunctional complexes as well. The most expensive business centre, Atrium at Nevski 25, hosts a large shopping arcade. The class C Sampsonievski 


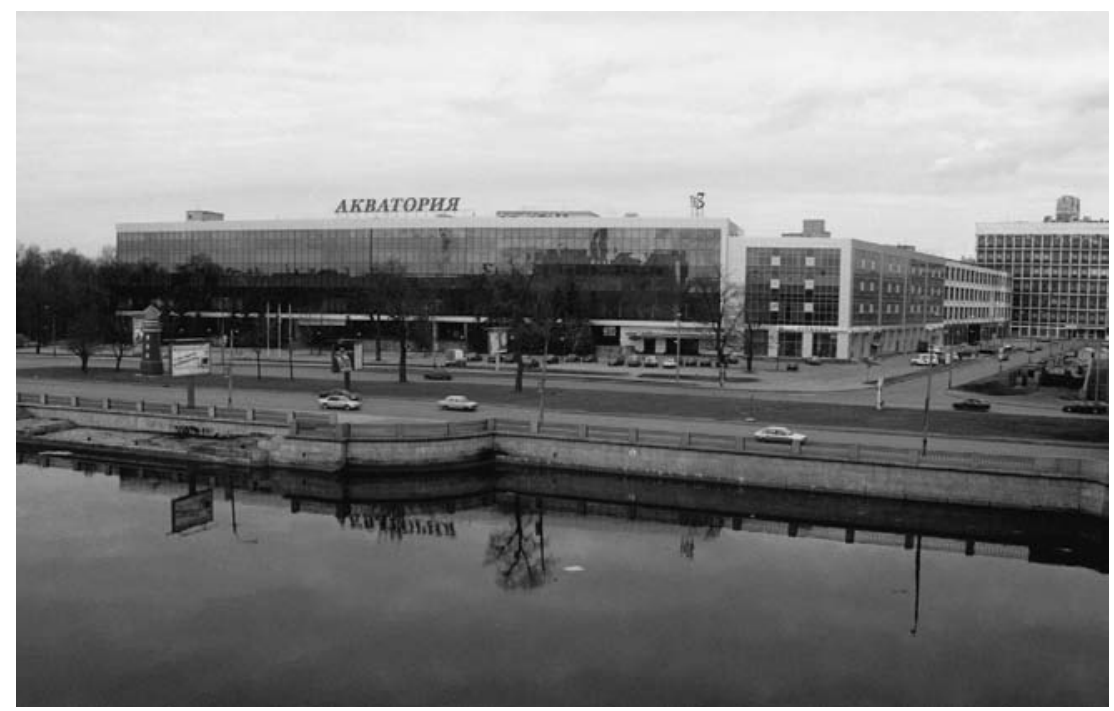

Figure 7.9 Aquatoria business centre

Source: Photo by F. Krenev.

business centre located in a former industrial area contains a hypermarket on the first two floors. One of the successful projects, Aquatoria, is an example of the steady redevelopment of a socialist-era industrial building. The first stage was an entertainment complex, and then a business centre was added (Figure 7.9). Some companies started to merge office space and manufacturing space, with the aim of providing something close to small techno-parks.

The locational strategy followed by business centres is dependent on their class. Class A, as well as some class B, business centres tend to be located exclusively in the most prestigious parts of the city centre, and normally occupy redeveloped historical buildings. Most class B and C business centres are redeveloped industrial or office buildings in the inner industrial belt (Figure 7.10).

Some business centres have even appeared in socialist-era hotels. There is also a tendency to locate business centres close to 'gravity centres', such as the St Petersburg exhibition centre or the Port of St Petersburg. Real estate experts consider that proximity to a metro station does not influence the differentiation in rent levels between business centres. They also specify that 'location' in the case of business centres implies a much wider variety of features than for other types of business establishments. It includes much stricter requirements of the neighbourhood and its immediate surroundings, such as views, accessibility, etc. For class A business centres, it is not only the centrality of a location that matters, but 


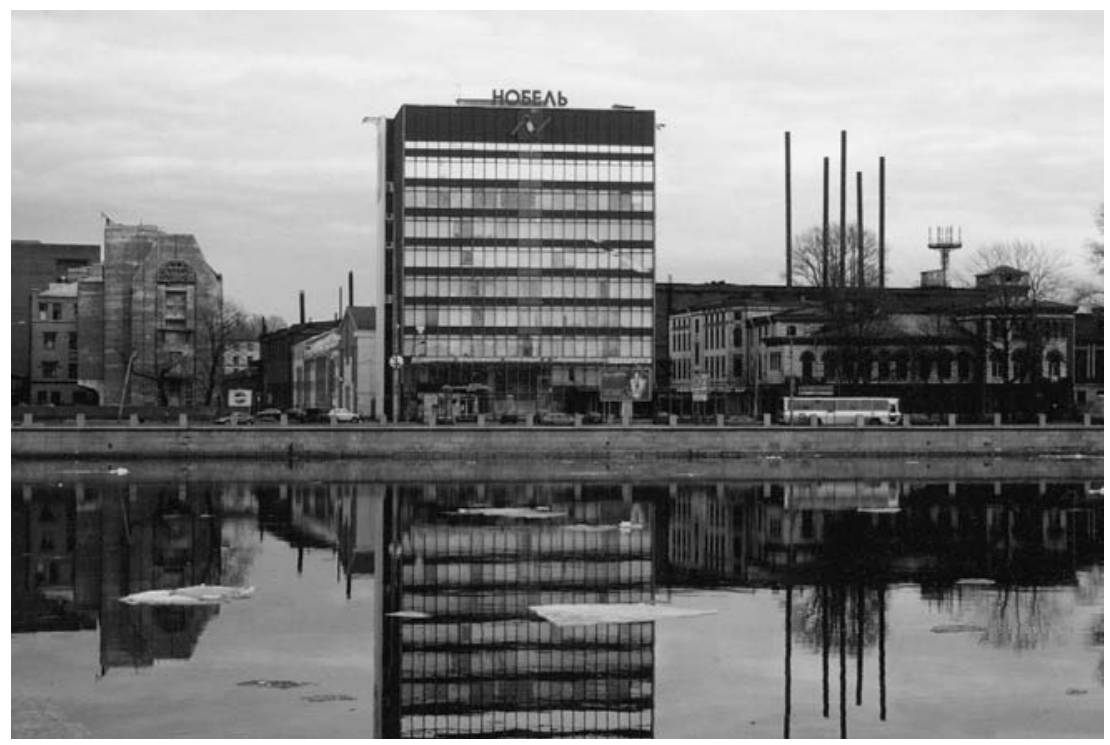

Figure 7.10 'Nobel' business centre

Source: Photo by F. Krenev.

also the public image and the surroundings (Delovoy Peterburg, 19 July 1999).

So the post-transformation stage resulted in the emergence of the wide range of new forms of retail and services facilities. Most of them are related with certain Western business forms. At the same time all of them have distinct differences in their locational practice from that of their Western 'relatives'. This difference in spatial behaviour is grounded in the presence of the remains of the transformation-stage of the consumption society stage of industrial phase shopping model and transformation-type facilities that new international operators have to consider in their marketing strategies. 


\title{
8 Post-transformation vs. modernization
}

\author{
Conclusions
}

The main message of the previous text lies in the evidence that the transformation of socialist space ordering into a new market-oriented one is complete. At least with regard to St Petersburg city space, one can witness another distinct stage of development, which we call post-transformation. As has already been shown, many authors treat St Petersburg as a city that shows feasible traces of world city formation (for example Taylor and Hoyler, 2000). This obviously means that St Petersburg has entered the international market and is actively looking for its place in the global urban network. All these trends are accompanied by the rapid restructuring of St Petersburg from an over-industrialized city to a multifunctional post-industrial centre (Litovka 1993; Agafonov and Isljajev 1995). Rapid growth of the tertiary sector of its economy is one of the clear indications for this.

In the first chapter we addressed the question whether post-socialist transformation would result in East European countries entering the uniform Westernized modernization trend or produce something different. This is the questions that we consider to be the major one in our study. If the latter is the case, what are the peculiarities that would allow one to describe post-transformational uniqueness? In other words, what are we dealing with at the end of transformation - Westernized, modernized and globalized society or post-transformation society, a specific form clearly distinguishable from the former?

We can state that the term 'post-transformation city' is not identical to 'modernized city'. Although the general modernization trend obviously underlines post-transformation development, the post-transformation city does have distinct peculiarities that distinguish it from other cities at the same stage of modernization.

When the spatial dimension of transformation and post-transformation have been the focus of our study, the essential finding for us is the existence of specific spatial forms and structures that emerged during transformation and that remained present in city space even after transformation was over. They are of a different origin from that of Western cities and now need to be integrated into the global context. 
At the beginning of our study we raised three questions as our research objective:

1 What have been the spatial processes connected to transformation and post-transformation in St Petersburg during the past 12-15 years?

2 What factors and actors contribute to these processes?

3 What new spatial structures emerged during these stages of the city's development?

We believe that we managed to answer all these questions. Some of the answers have already been summarized in the text above (see Table 1.1).

One of the central mechanisms of spatial adaptation of a large socialist city to the introduction of market forces is what we have called spatial saturation with consumer goods and services. This is a space-time process having various spatial forms and specific time stages. Locational priorities that originate from the business requirements of a trade branch may differ in their spatial impetus from factors resulting from the interests of territorial complex building. The branch priorities are heavily based on what we call the spatial division of the market and introduce a centrifugal impetus to the whole spatial system of tertiary sector location. Territorial complex building introduces centripetal forces to this system. Their joint effect produces different spatial patterns at different stages of spatial saturation. These time stages and related spatial patterns were observed at different spatial scales - from a kiosk agglomeration, which could be measured in single metres, to city-wide effects, of which there are numerous examples. This leads us to believe that the mechanisms, stages and patterns of the spatial saturation process described in this book are an essential part of the adaptation of post-socialist St Petersburg to market relations in the retail and service sector. ${ }^{1}$

Spatial saturation plays an important role as an indicator for distinguishing between transformation and post-transformation stages of city space development. We consider that transformation ends with the general achievement of saturation of city space with consumer goods and services and the simultaneous introduction of international business forms, locational patterns and capital.

In most Western cities, rapid growth of the retail trade and services sector marked the transition from the saturated market demand of industrial society to the saturated market demand of post-industrial society. The transformation of the retail trade and services sector in St Petersburg marks the change from the under-saturated market demand of industrial society to the saturated demand of post-industrial society. This means that the development of St Petersburg city space has passed through different stages even within the same general modernization trend as that of Western cities. The stage of consumption society that marked the industrial stage of development in most Western cities has produced specific 
spatial structures and forms. Post-industrial trends brought in new spatial structures that had to meet the challenges of the old ones and either compete or just share city space with them. Neither the socialist city nor the transformational one reached the consumption society stage during their industrial phase. The respective spatial structures and forms could never appear in its space. Transformation thus brought together several processes that a Western city either experienced during separate rather long periods of time or never witnessed at all. During a 15-year period St Petersburg has had to meet the transition from Fordism to post-Fordism, from a socialist-centralized planned economy to a market-driven economy, as well as the adoption of both consumer society and post-industrial models simultaneously. In less than 15 years the city has jumped over several stages of modernization that lasted for several decades in the West. No wonder that its space lacks certain structures that are characteristic of Western cities and at the same time hosts unique ones inherited from the socialist and later transformation city spaces.

We can state so far that the distinguishing feature of a posttransformation city is the existence of unique hybrid spatial structures that bring together socialist, transformation and international business forms in a sort of interrelated system, which we call post-transformation city space.

In Table 8.1 we summarize the features of each of the periods related to our topic. We trace three crucial spatial indicators that distinguish the periods outlined: spatial shopping models, specific business forms and location principles applied in retail trade and services. As we have shown, the shopping model, which is heavily dependent on socio-economic parameters of the population, in fact shapes the demand for certain types of business location in retail trade and services.

One could observe several dramatic changes in shopping behaviour in Leningrad-St Petersburg throughout the last 15 years. While during socialist and transformation periods one distinct type of shopping behaviour prevailed in each period, post-transformation brought into being a splitting of shopping models into several types that follow social stratification.

Different requirements of changing shopping models, different stages of market development (capitalization being of primary importance) and regulations ${ }^{2}$ all influenced the development of certain business forms suitable for each stage. All of the above introduced different sets of locational principles that were characteristic for each of the periods. All of them are described in some detail in the text.

Thus the post-transformation phenomenon does exist and does shape city space that differs both from that of the general modernization model and from the previous stages of post-socialist city development. To summarize the major features of the post-transformation city space once more, we can say the following. 


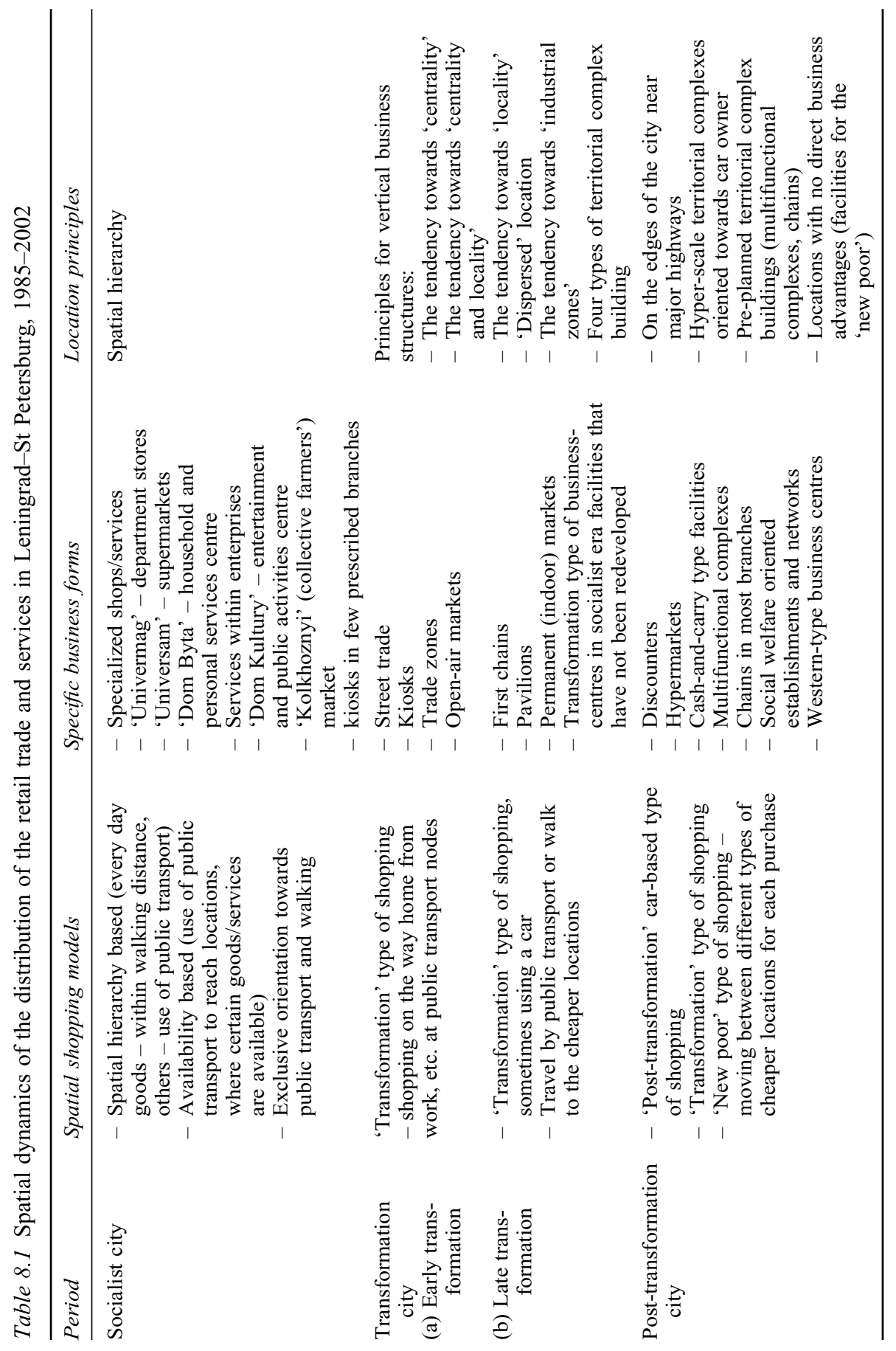


The following features distinguish the post-transformational system of factors affecting the spatial distribution of business in St Petersburg from the previous transformational one. First, the location of business is no longer directly regulated by the market alone. Second, the city administration has obtained the role of market regulator in the location process. Third, the role of informal regulation has dropped substantially. The leading role played by the factors of urban morphology and the patterns of transportation has replaced the overall dominance of the principle of spatial hierarchy that prevailed under socialist planners.

The development of conventional international trade forms, which constitutes the basis of the post-transformation stage, has to occur in a context that takes the specificity of the transformation and socialist heritage into account. Specific transformation trade forms in their present shape constitute real and effective spatial and business competitors for the incoming international and Russian retail capital. The development of the specific trade forms that emerged during transformation is thus far from over.

There are three major differences between the processes that govern the spatial organization of retail trade and services in St Petersburg during the post-transformation stage of development, and those of the transformation stage. First, if under transformation the process of saturating consumer demand for merchandise shapes a new spatial pattern of location for retail trade and services, the post-transformation period is marked by the end of the saturation process and the launching of attempts to recast business actors under conditions of generally saturated demand. Second, the structure of demand and the related shopping models are diversifying and becoming very different from those of the transformation stage. Third, the emerging post-transformational business forms act upon different locational preferences.

We conclude so far that there exists a distinct post-transformation type of urban space development that follows the general modernization trend. We can theoretically foresee that if no radical socio-economic and political changes happen in this part of the world, globalization and modernization will overcome the heritage of transformation and socialist heritage, making the present hybrid urban space structures more uniform with the rest of the globe. 


\section{Notes}

\section{Post-industrial vs. post-socialist}

1 Socio-ecological theory is based upon the principles of private capitalism, meaning that urban development is viewed as a process that determines its own course (Lichtenberger, 1998). The structure and development of cities, according to this theory, is influenced by non-societal factors (also referred to as 'natural' factors during the early phase of socio-economic thinking), such as demographic development, locational competition and the stage of development of production and communication technology (Friedrichs, 1978).

2 Fordism: standardization of products, mass production, high-wage policy and mass consumption. Keynesianism: system of state intervention and state regulation; social welfare guaranteed by the state.

3 Paris, Madrid, Hamburg, Berlin, Budapest, Moscow.

4 Other 'Eastern European, un-European' cities in this list are supposed to be Budapest, Helsinki and Istanbul. The authors also include in this 'un-European' category 'four international finance centres, including Europe's two leading world cities London and Paris, which have global specificities to prevent them being very similar to other European cities' (Taylor and Hoyler, 2000).

5 Some of these factors in more detail are discussed by A. French (French, 1995).

6 A survey conducted in St Petersburg with 840 private enterprises revealed that more than a third of them were formerly parts of armaments factories; of these, about 48 per cent were engaged in the area of research and development (OCC, 1997, p. 266, quoted in Rudolph 1999a, p. 11).

7 Eger, 2000, viewing transformation as a process of comprehensive and primarily economic, institutional change, outlines five dimensions: retreat of the state (privatization, liberalization); reallocation of resources, reorganization of production and productive capacities; redistribution; decentralization.

8 Von Hirschhausen, 2001, specifies four levels of transformation: constitutional; economic; societal; technological.

9 Quite substantial and noticeable changes became apparent in economic statements issued by the Russian government and even in the terminology used during 2001. For example, at the Ministry of Economic Development open session devoted to the economic report for 2001, the Russian prime minister, M. Kasianov, spoke about the new stage of reform planning. According to him, Russian economic development is no longer exclusively dependent upon the world oil and gas market: 'Now economic growth is based mostly upon growing internal demand and modernizing tendencies within the Russian economy that are already irreversible.' He recommended that the ministry aimed at an acceleration of the economy to such an extent that 'the progress would be visible 
not only in comparison with the crisis of 1998, but rather as compared to our major competitors - other countries' (www.gazeta.ru, 12 April 2002).

10 Stanley Fisher, the Chief Economist of the IMF (International Monetary Fund), described transformation in Russia as a 'return to a system that is well understood in the rest of the world' (Fischer, 1994, cited in Hirschhausen, 2001).

11 Discussion on the spatial dimension of transformation is extensive. One of the latest accounts can be found in Rudolph, 2001, pp. 16-30.

12 Normally through the lives of several generations of a Leningrad family, the places where they lived, where they went shopping and where they accessed services remained the same. This relates not only to the allocation and specialization of a shop but even to the type and even producer of the available or expected merchandise.

13 Cooperative property generally refers to the collective farms and related facilities, such as the collective farmers' markets in the cities, where they could sell their products. During some periods of socialist rule, cooperatives were permitted in small-scale industrial production and the service sector.

14 The term 'personal property', as opposed to 'private property', was adopted by Soviet officials in order to stress that a Soviet citizen could not earn income from this property. Numerous private country houses and family homes in the cities were classed as 'personal property', and could not be legally leased or sold for profit. The land on which these were built was considered state property.

15 This point receives particular attention in our study.

16 This was discussed in Axenov, 2001.

17 St Petersburg being the innovative leader of Russian economic restructuring, allowed, de facto, a certain degree of private ownership of land, particularly on the part of industrial enterprises. But quite understandably these legal acts were considered rather unreliable.

18 St Petersburg, like Moscow, has the status of a subject of the Russian Federation. This means that the authorities have legislative and executive power, as well as performing the functions of municipal administration. Since 1997, 111 municipal councils have been elected in St Petersburg; these are mainly responsible for local matters. Responsibility for decision-making on matters that relate to the whole city, such as city planning and legal regulations, lies with the city governor, his administration and the legislative council.

\section{Changes in the functions of St Petersburg as a prerequisite for structural change in the city}

1 In contrast to the city, the region of Leningrad has retained its old name and is called the Oblast of Leningrad. In a referendum in September 1991 the city voted to reassume the original name of St Petersburg.

2 The Russian institute for economic analysis, 'Expert', carries out a yearly rating of the regions using indicators related to investment risk and investment potential (source: www.expert.ru/rating/regions/reg2001/t01.htm).

3 http://gov.spb.ru; information as of 17 March 2002.

4 The construction of the following port facilities in the southern and northern parts of the Gulf of Finland is planned: Ust Luga (35 million tons per annum, loose goods, timber, container freight); Batareynaya Bay (15 million tons per annum, petroleum products); Vysokinskij rayon (4 million tons per annum, ammonia, liquid gas), Vysotskiy island (5-7 million tons per annum). In addition, there are plans to expand the petroleum terminal at Primorsk, which opened in December 2001, as well as to rebuild the port of St Petersburg and increase 
its capacity to 30 million tons. (Kommersant daily, 26 November 1996; Sankt Peterburgskie vedomosti, 2 July 1998; Geografija, No. 9/2002).

5 This and the following paragraph are based on information derived from the 1998 Strategic Plan, and from the Committee for Foreign Relations of the St Petersburg Administration in March 2001.

6 Trade turnover with the CIS fell by 34 per cent in the first half of 1997 compared with the previous year; at the same time, however, trade turnover with the rest of the world increased by 25 per cent.

7 The increase is primarily due to the opening of plants with foreign partners such as Wrigley, Gillet International, Petmol (baby food), the opening of an oil terminal by the Finnish company Neste and the takeover of the Vena and Bravo breweries.

8 The capital flows from Cyprus are mainly the result of Russian companies reinvesting capital that they had previously transferred abroad.

9 Excluding joint ventures and small businesses.

10 This includes purely Russian ventures and Russian-foreign companies.

11 Prior to August 1998 foodstuffs were imported on a huge scale; however, after the financial crisis the level of imports dropped because they became much more expensive. Russian producers that offered quality, competitively priced products were able to use this opportunity to secure a stable share of the market. Particularly in the area of foodstuffs, import substitution occurred. At the same time, foreign-owned manufacturers of foodstuffs and semi-luxury foods and tobacco started to use raw materials produced in Russia.

12 For a more detailed account of the market for office space in St Petersburg see Rudolph, 2001, p. 140ff.

13 The seller remains the owner of the building. The buyer buys (or leases) the rights to use the building; cf. user's rights.

14 Source: www.gov.spb.ru (3 December 2002).

\section{Transformation, tertiary sector and city}

1 We consider the term 'territorial complex' to be more precise than 'cluster' in describing these spatial forms. In some cases cluster could be treated as a group of individual items brought together due to some external force or just common feature. Complex assumes that all the items are closely interrelated to each other as a system due to internal reasons.

2 Minor exceptions were the sites, where the kolkhoz (collective farms) held markets and performed handicrafts, and a few services. On the lowest scale these agents could compete for, or influence the location of their facilities within certain spatial limitations. But these limitations were nonetheless prescribed by the state.

3 In an economy not exclusively dependent on monetary relations, preferential access to the distribution system was considered much more valuable than money.

4 Some of these structures will be described in Chapter 4.

5 For example, the city has yet to complete a cadaster (land register), which could regulate land use under market conditions.

6 Stricter control over the legislation process in St Petersburg than in many other subjects of the Russian Federation results, above all, from the very active presence of the Legislative Council, which acts in many cases as a constructive opponent of the city administration.

7 St Petersburg was the first large city in Russia to adopt such a plan. 'From a legal viewpoint, the St Petersburg's Strategic Plan is an agreement among 
different branches of power, the business community, public organizations and other parties in which they assume the obligation to promote the adopted or most important strategic projects and actions. ... For this reason the Strategic Plan was structured as a public consensus built through an organized and transparent dialogue between the city authorities, business community, and the public. Thus the St Petersburg's Strategic Plan was developed and implemented on the basis of public-private partnership. The Strategic Plan focused on four 'strategic development areas': (1) formation of a favorable business climate; (2) integration in the world economy; (3) improvement of the urban environment; and (4) formation of a favorable business climate' (Vetrov, 2002).

8 A federal law on the protection of consumers' rights was adopted in the mid1990s.

9 An official St Petersburg website contains the first basic guides to such procedures (http://petersburgcity.com/business/expert/realestate), as well as to the investment tax climate, and the official 'Saint Petersburg Business Guide'. Supported by the city administration, the website 'Information Society of St Petersburg' provides a list of the major administrative regulations and laws on real estate and land use as well as other spheres (www.infodev.spb.ru/eng/ law.html). More information on business regulations is provided by other official websites (www.government.spb.ru, www.investor.spb.ru, www.stateinvest. spb.ru).

10 In 2001 several vice-governors, their deputies and other top officials of the city administration were exposed to a legal trial and resigned. Two city deputies and several leading businessmen were jailed after convictions related to their involvement with organized criminal groups.

\section{Transformation and specific forms of spatial saturation}

1 Dr Alexis Papadopoulos contributed to the material used in this chapter.

2 We analyse the spatial organization of standard trading forms separately in the next chapters.

3 In addition to the GOST terms, we also use definitions used by officials from the St Petersburg Administration Consumer Market Department in interviews held in June 2000.

4 This included the requirement that the projects be approved by the architectural and artistic authorities of the city administration, resulting in standardized constructions recommended by city and regional authorities, etc.

5 For example, from May 1997 it became compulsory to provide basic information about imported merchandise in Russian. This norm affected, in the first instance, the small retail operators, whose supply sources were based on 'shuttle' import (for more on 'shuttle' import see Axenov, Brade and Papadopoulos, 1997).

6 Other estimates give a figure of 458 small retail trade zones (Sankt-Peterburgskie Vedomosti, 10 September 1997).

7 If we were to calculate the number of small retailers who were moved to the markets, this reduction in showcase area would be even more marked.

8 As mentioned already, according to the 'kiosk-type' of shopping behaviour, people tended to do shopping on the way home rather than on the way to work or to other destinations.

9 For a more detailed description of a 'shuttle' operation, see Axenov, Brade and Papadopoulos, 1997; Papadopoulos and Axenov, 2002. 


\section{The spatial transformation of vertical business structures}

1 Here, as in this entire chapter, we refer only to the fixed space stores.

2 Since our data base included only three surveys, we may have missed some intermediary stages.

3 Our expertise method was based on the independent examination of the 34 above-mentioned maps by each of the three authors. We chose the 34 branches, which were subject to the most rapid change and/or were the most numerous (as in the case of food stores). The aim of such an examination was to distinguish the locational priorities for each spatial distribution pattern. Those priorities that were observed by all three authors independently were included in the final list.

4 The new structure and functions of the city centre were the subject of a recent study (Rudolph, 2001).

5 Some authors even describe such a structure as being characteristic for a socialist and post-socialist city in general (Sailer-Fliege, 1999).

6 It is impossible to make direct comparisons of Figures 5.8 and 5.9. Due to technical reasons we could not use data from the same number of branches for both figures. For Figure 5.8 we used data on 55 branches, while for Figure 5.9 we were restricted to 19 selected branches representing all locational types.

\section{Territorial complex building}

1 See Chapter 3.

2 As an example of a typical city centre section we attach the description of Mayakovskaya metro station area in an Appendix to this chapter.

3 Hereafter, we list all the branches that make more than 3 per cent of the total number of the tertiary sector enterprises within the site.

\section{Post-transformation urban space}

1 In Moscow retail turnover exceeds US\$5 billion p.a., and constitutes 30 per cent of the total retail trade volume of Russia (Delovoy Peterburg, 18 October 2001). See also Treivish, Brade and Nefedova, 1999.

2 Annual amount of sales per square metre of trading space.

3 Social stratification within a post-Soviet city has a distinct spatial dimension that we do not discuss here (see, for example, Vendina, 1997).

4 The authors of this survey state that they did not include the extremely rich, so one could expect this ratio to be even bigger.

5 Some Russian retailers are following the path taken by some of the local industrial manufacturers in the early 1990s, and 100-per-cent Russian companies have started to promote brand names that sound Western. For example, the big Russian textile manufacturer LAK started a hypermarket chain under the brand name PLATO using not Cyrillic, but Latin characters.

6 Lenta plans to build a chain of up to ten hypermarkets (Delovoy Peterburg, 26 February 2002).

7 By 2002, a new residential development was completed close to the Super-Siwa location, but the scale of these facilities greatly exceeds the capacity of the local market.

8 Unlike other cash-and-carry chains, Uniland follows a strategy of occupying smaller spaces and investing less in real estate, refurbishment and promotion. 


\section{Notes}

This means, above all, that its locational policy is much more flexible, it can locate facilities in socialist-type supermarkets and even on the periphery of the city centre, possibly leading to higher efficiency of trading space. This puts Uniland in an intermediate position between cash-and-carry hypermarkets and discounter chains, which provide merchandise for another type of clientele.

9 While the Salova Street complex was previously an example of territorial cooperation between interrelated branches, it now started to attract and share the target customers - car owners - with unrelated branches.

10 The average trading space of an individual outlet in this chain is less than 200 square metres.

11 Investment in an average Pyatiorochka store in St Petersburg was estimated at US\$0.8-1 million, while investment in the chain's warehousing and distribution centre totalled US\$10 million.

12 Though by 2002 this policy was the subject for political debates.

13 Soon after that this chain stopped operation. In March 2004 the whole chain of 26 shops was purchased by Phaeton holdings and started to operate under the 'Funtik' brand name (www.retailer.ru).

\section{Post-transformation vs. modernization}

1 Major features of the stages of spatial saturation were summarized in Table 4.5.

2 See figures $3.2 \mathrm{a}-\mathrm{c}$. 


\section{Bibliography}

Agafonov, N. and R. Isljajev (1995) Osnovnye polozhenija koncepcii perechoda Rossijskoi Federacii na model ustoichivogo rasvitia (Basic issues of the concept of approaching the sustainable development model for Russian Federation), Sankt Petersburg: Russian Academy of Sciences.

Andrusz, G. (1984) Housing and Urban Development in the USSR, London: Macmillan.

Andrusz, G., M. Harloe and I. Szelenyi (eds) (1996) Cities after Socialism, Oxford: Blackwell.

Aring, J. (1999) 'Suburbia - Postsuburbia - Zwischenstadt' ('Suburbia - Post-suburbia - Inbetween-ville'), Arbeitsmaterial / Akademie für Raumforschung und Landesplanung, Hanover.

Axenov, K. (2001) 'Spatial saturation as the adaptation of a post-socialist city to market relations in retail trade and services: The case of St Petersburg', in I. Brade (ed.) Die Städte Russlands im Wandel. Raumstrukturelle Veränderungen am Ende des 20. Jahrhunderts (Russian cities under transformation. Changes in the structure of urban space at the end of the 20th century), Beiträge zur Regionalen Geographie 57.

Axenov, K. (2001) 'Izmenenia v razmeschenii roznichnoi torgovli i uslug pri perekhode k rynochnoi ekonomike (na primere Sankt-Peterburga, 1988-1996 gg.') ('Changes in the distribution of retail trade and services during the transition to a market economy (the case of St Petersburg, 1988-1996)'), Izvestia Russkogo Geograficheskogo Obschestva, 2: pp. 58-71.

Axenov, K. and O. Vendina (1999) 'Moskva i Peterburg: zakonomernoe razvitije ili stikhinaja transformacija gorodskovo prostranstva?' ('Moscow and St Petersburg: law-governed development or spontaneous transformation of urban structures?'), in Rossiskaja Akademija nauk - Institut mezhdunarodnych ekonomitcheskikh $i$ polititsheskikh issledovani/Institut geografii (ed.): Moskva na fone Rossii i mira: problemy $i$ protivoretshija otnosheni stolicy $v$ kontexte rynotshnoi transformazii (Moscow, Russia and the world: Problems and contradictions in the structures of the capital in the context of transformation) Moscow: Epicon.

Axenov, K., I. Brade and A. Papadopoulos (1996) 'Neue Einzelhandelsformen in St Petersburg: Der Übergang zu marktwirtschaftlichen Bedingungen' (New forms of retail trade in St Petersburg: the transition to market-economy conditions'), Europa Regional, 4 (3): pp. 13-23. 


\section{Bibliography}

Axenov, K., I. Brade and E. Bondarchuk (1997) 'The new retail trade and services and their emerging location patterns in St Petersburg', GeoJournal, 42 (4): pp. 403-17.

Axenov, K., I. Brade and A. Papadopoulos (1997) 'Restructuring the kiosk trade in St Petersburg: a new retail trade model for the Post-Soviet Period', GeoJournal, 42 (4): pp. 419-32.

Bater, J. (1980) The Soviet City: Ideal and Reality, London: Edward Arnold.

Bater, J. (1996) Russia and the Post-Soviet Scene, New York: Wiley.

Beaverstock, J., R. Smith and P. Taylor (1999) 'A roster of world cities', Cities, 16 (6): pp. 445-58.

Bondarchuk, E. (2001) 'Territorialnaja organisazija tretitschnego sektora ekonomiki Sankt-Peterburga' ('The territorial organization of the tertiary economic sector in St Petersburg') Ph.D. thesis, State University of St Petersburg.

Brade, I. (1994a) 'St Petersburg - Bedeutungswandel und Entwicklungsperspektiven einer osteuropäischen Metropole' (St Petersburg - the change in significance and prospects for development of an Eastern European metropolis), Europa Regional, 2b (1): pp. 1-13.

Brade, I. (1994b) 'St Petersburg - das Fenster nach Europa' ('St Petersburg - the window on Europe'), Praxis Geographie, 24 (10): pp.18-23.

Brade, I. (1998) 'Die Zeit der Metropolen - auch im östlichen Europa? St Petersburg im postindustriellen Zeitalter' ('The age of metropolises - in Eastern Europe too? St Petersburg in the post-industrial age'), Zeitschrift für den Erdkundeunterricht, 50 (3): pp. 150-8.

Brade, I. and M. Schulze (1997) Rußland - aktuell (Russia - now), Leipzig Series Daten - Fakten - Literatur, 4, Leipzig: Institut für Länderkunde.

Brade, I., D. Piterski and M. Schulze (2002) 'Einflussfaktoren und Rahmenbedingungen der Stadt- und Regionalentwicklung in Russland' (Factors of impact and general conditions of cities and regional development), in I. Brade (ed.) Die Städte Russlands im Wandel. Raumstrukturelle Veränderungen am Ende des 20. Jahrhunderts. Beiträge zur Regionalen Geographie 57, Leipzig: LeibnizInstitut für Länderkunde.

Bradshaw, M. (1997) Geography and Transition in the Post-Soviet Republics, New York: Wiley.

Bradshaw, M. and A. Stenning (eds) (2004) East Central Europe and the Former Soviet Union. London: Pearson

Brake, K., R. Danielzyk and Karsten, M. (1996) Dezentrale Konzentration. Empirische Implikationen eines raumordnerischen Leitbildes (Decentralized concentration: Empirical implications of a spatial model). Arbeitsmaterialien, Forschungsinstitut Region und Umwelt, Oldenburg: Forschungsinstitut Region und Umwelt.

Burawoy, M. (1994) 'The end of the Sovietology and the renaissance of modernization theory', Contemporary Sociology, 21 (6): pp. 774-84.

Burdack, J. (2001) 'Die städtische Peripherie zwischen 'suburbanen' und 'postsuburbanen' Entwicklungen' ('The urban periphery between 'suburban' and 'post-suburban' development'), Berichte zur deutschen Landeskunde, 75 (2/3): pp. 188-96.

Burdack, J. and G. Herfert (1998) 'Neue Entwicklungen an der Peripherie europäischer Großstädte' ('New developments on the periphery of European cities'), Europa Regional, 6 (2): pp. 26-44. 
Burdack, J. and R. Rudolph (2001) 'Postsozialistische Stadtentwicklungen zwischen nachholender Modernisierung und eigenem Weg' ('Post-socialist urban development between catch-up modernization and a separate path'), Geographica Helvetic, 56 (4): pp. 261-73.

Castells, M. (1993) 'European cities, the information society, and the global economy', evoor Economische en sociale Geografie, 84.

Clark, D. (1996) Urban World/Global City, London: Routledge.

Danielzyk, Rainer (1998) Zur Neuorientierung der Regionalforschung - ein konzeptioneller Beitrag (On the Reorientation of Regional Studies - A Conceptional Contribution), Wahrnehmungsgeographische Studien zur Regionalentwicklung 17, Oldenburg: Verlag.

Dietz, R. (1992) 'Ten propositions towards a theory of transformation: from command to exchange communication', in S. Richter (ed.) The Transition From Command To Market Economies in East-Central Europe, Oxford: Westview Press.

Dingsdale, A. (1999) 'Budapest's built environment in transition', GeoJournal, 49 (1): pp. 63-78.

Dokutshayev und Kolesnikov (1998) 'Sociologija krisisa' ('The sociology of crisis'), Isvestija, 30 October 1998.

Eger, T. (2000) 'Systemtransformation: Die fünf Dimensionen der Transformationsprozesse in Osteurope'. In Discussion Papers of Frankfurt Institute for Transformation Studies 12, Frankfurt: Europa - Universität Viadrina (Oder).

Entsiklopedicheskiy spravochnik: Sankt-Peterburg - Petrograd - Leningrad (Encyclopedia reference book: Sankt-Peterburg - Petrograd-Leningrad) (1992), Moskva: Nauchnoe Izdatelstvo.

Enyedi, G. (1994) 'Der Wandel postsozialistischer Städte' ('Changes in post-socialist cities'), Mitteilungen der Österreichischen Geographischen Gesellschaft, 136: pp. 53-70.

ETLA Solid Invest, (2004) Biannual Monitoring Report St Petersburg in 2003, p. 2, www.economicmonitoring.com/data/reports/Spb_May_2004_ENG.pdf, 28 October 2004.

Fassmann, H. (1997) 'Regionale Transformationsforschung. Theoretische Begründung und empirische Beispiele' ('Researching transformation in regional studies. A theoretical basis and empirical examples'), in A. Mayr (ed.) Regionale Transformationsprozesse in Europa (Regional Processes of Transformation in Europe), Beiträge zur Regionalen Geographie, 44 Leipzig: Institut fuer Laenderkunde.

Fassmann, H. and E. Lichtenberger (1995) Märkte in Bewegung - Metropolen und Regionen in Ostmitteleuropa (Markets in Motion - Metropolises and Regions in Central and Eastern Europe), Vienna/Cologne/Weimar: Böhlau-Verlag.

Faszinierende Städte - St Petersburg. Bildband (Fascinating cities - St Petersburg. Picture book) (1993) Frankfurt am Main: Umschau.

Fischer, S. (1994) 'Russia and the Soviet Union then and now', in O. Blanchard, K. A. Froot and J. Sachs (eds) The Transition in Eastern Europe, Vol. 1: Countries, Chicago IL: University of Chicago Press.

French, R. A. (1995) Plans, Pragmatism and People: The Legacy of Soviet Planning for Today's Cities, Pittsburg KS: University of Pittsburg Press.

French, R. A. and F. E. I. Hamilton (eds) (1979) The Socialist City, New York: John Wiley. 


\section{Bibliography}

Friedmann, J. (1986) 'The world city hypothesis', Development and Change, 17: pp. 69-84.

Friedrichs, J. (1978) Stadtentwicklungen in kapitalistischen und sozialistischen Ländern (Urban Development in Capitalist and Socialist Countries), Reinbek bei Hamburg: Rowohlt Taschenbuch Verlag.

GOST P 51303-99 'State standard of the Russian Federation: Trade. Terms and Definitions', in force since January, 1, 2000, Moscow.

Grabher, G. and D. Stark (1998) 'Organisation der Vielfalt: Evolutionstheorie, Netzwerkanalyse und Postsozialismus' ('Organizing diversity: evolutionary theory, network analysis, and post-socialism'), Raum, 32.

Grimm, F.-D. et al. (1994) 'Zentrensysteme als Träger der Raumentwicklung in Mittel- und Osteuropa', in F.-D. Grimm (ed.) Beiträge zur Regionalen Geographie 37, Leipzig.

Gritsai, O. (1997) 'Business services and restructuring of urban space in Moscow', GeoJournal, 42 (4), pp. 365-76.

Gritsai, O., A. Ioffe and A. Treivish (1991) Centr i Periferija v regionalnom razvitii (Centre and Periphery in Regional Development). Moscow: Nauka.

Gumpel, W. (1997) 'Ein Land am Abgrund - Zur wirtschaftlichen Lage in Rußland' ('A country on the abyss - on the economic situation in Russia'), Osteuropa, 47 (8): pp. 762-71.

Harris, C. D. (1970) Cities of the Soviet Union. Studies of their Functions, Size, Density and Growth, Chicago IL: Rand McNally.

Häussermann, H. (1997) 'Von der sozialistischen zur kapitalistischen Stadt' ('From the socialist to the capitalist city'), in Z. Kovács and R. Wiessner (eds) 'Prozesse und Perspektiven der Stadtentwicklung in Ostmitteleuropa' ('Processes and prospects of urban development in Central and Eastern Europe'), Münchner Geographische Hefte, 76, p. 21-32.

Hesse, M. and S. Schmitz (1998) 'Stadtentwicklung im Zeichen der "Auflösung" und "Nachhaltigkeit"" ("Urban development under the sign of "spreading" and "sustainability"), Informationen zur Raumentwicklung, 7-8, pp. 435-53.

Hirschhausen, C. von (2001) The Process and the End of Systemic Transformation - A Survey of Central/Eastern Europe and the former Soviet Union in the 1990s, Tagung der Deutschen Gesellschaft für Osteuropakunde, Fachgruppe Wirtschaftswissenschaften, Berlin: German Institute for Economic Research.

Hirschhausen, C. von and T. Waelde (2001) The End of 'Transition', Moct-Most Economic Policy in Transitional Economies, 11(1), Berlin: German Institute for Economic Research.

Hitz, H., C. Schmid and R. Wolff (1992) 'Zur Dialektik der Metropole: Headquarter economy und urbane Bewegungen' ('The dialectics of metropolises: The headquarter economy and urban progress'), Geographische Zeitschrift, 80, pp. 57-83.

Karger, A. (1987) Die Sowjetunion als Wirtschaftsmacht (The Soviet Union as an Economic Power), Frankfurt am Main: Campus.

Karsten, H. and D. Janke (1974) Das Verkaufsstellennetz (Network of Sales Positions), Berlin: Verlag Die Wirtschaft.

Kihlgren, A. (2003) 'Economic policy in post-Soviet St Petersburg', Eurasian Geography and Economics, 44 (5): pp. 368-83.

Klüter, H. (1992) 'Russland und die Auflösung der Sowjetunion - Ursachen und Folgen aus wirtschaftsgeographischer Sicht' ('Russia and the break up of the 
Soviet Union - causes and consequences from an economic-geography perspective'), Geographische Zeitschrift, 80 (1): pp. 20-38.

Kolossov, V., O. Vendina, and J. O'Loughlin (2002) 'Moscow as an emergent world city: international links, business developments, and the entrepreneurial city', Eurasian Geography and Economics, 43 (3): pp. 170-96.

Kolossov, W., O. Vendina, N. Borodulina et al. (1998) 'Sosdanije novoi predprinimatelskoi sredy v Moskve: osnovnye tendencii i protivorechija' ('The development of a new entrepreneurial milieu in Moscow: trends and contradictions'), Isvestija RAN, serija geograficheskaja 48 (5): pp. 95-109.

Kostinskiy, G. (2001) 'Post-socialist cities in flux', in R. Paddison (ed.) Handbook of Urban Studies, London: Sage Publications.

Kovacs, Z. (1999) 'Cities from state-socialism to global capitalism: An introduction', GeoJournal, 49 (1): pp. 1-6.

Krätke, S. (1991) Strukturwandel der Städte. Städtesystem und Grundstücksmarkt in der postfordistischen Ära (Structural change in cities. The urban system and property market in the post-Fordist era), Frankfurt am Main/New York: Campus Verlag.

Krätke, S. (1995) Stadt - Raum - Ökonomie (City - space - economy), Stadtforschung aktuell 53, Basel, Boston, Berlin: Birkhäuser.

Kratkiy statisticheskiy spravochnik Sankt-Peterburga (2000) (A Short Statistical Guidebook of Saint-Petersburg) (2001) St Petersburg: Sankt-Peterburgskiy komitet gosudarstvennoy statistiki.

Leborgne, D. and A. Lipietz (1994) 'Nach dem Fordismus' ('After Fordism'), in P. Noller, W. Prigge and K. Ronneberger (eds) Stadt-Welt - Über die Globalisierung städtischer Milieus (City-World. The Globalization of Urban Milieus), Frankfurter Beiträge 6, Frankfurt am Main, New York: Campus.

Lichtenberger, E. (1994) 'Das metropolitane Zeitalter in Europa in West und Ost' ('The metropolitan age in Western and Eastern Europe'), Mitteilungen der Österreichischen Geographischen Gesellschaft,136: pp. 7-36.

Lichtenberger, E. (1995) 'Politische Systeme und Stadtentwicklung in Europa' ('Political systems and urban development in Europe'), Zeitschrift für den Erdkundeunterricht, 47 (10): pp. 382-8.

Lichtenberger, E. (1998) Stadtgeographie 1. Begriffe, Konzepte, Modelle, Prozesse (Urban geography 1. Ideas, concepts, models, processes), Stuttgart, Leipzig: B. G. Teubner.

Litovka, O. (1993) Razvitie territorialnoy organisacii centrow i regiona (Development of the spatial organization of the centres and the regions) St Petersburg: Institute for Regional Research.

Litovka, O. (1995) 'Strukturelle Umgestaltung der Wirtschaft der St Petersburger Region' ('The structural re-shaping of the economy of the St Petersburg Region'), in A. Kogut, and F. Vetter (eds) St Petersburg - Führer 1995 (St Petersburg Guidebook 1995), St Petersburg: Institut Socialno-Ekonomiceskich Problem.

Lovering, J. (1989) 'Postmodernism, marxism and locality research: The contribution of critical realism to the debate', Antipode, 21 (1): pp. 1-12.

Marcuse, P. and R. van Kempen (eds) (2000) Globalizing Cities. A New Spatial Order? Oxford: Blackwell.

Marcuse, P. and van Kempen, R. (eds) (2002) Of States and Cities, Oxford: Oxford University Press. 


\section{Bibliography}

Massotti, L. M. and J. K. Hadden (eds) (1973) 'The Urbanisation of the Suburbs', Beverly Hills, CA.

Matthiesen, U. (1999) 'Stadtentwicklungen im östlichen Europa' ('Urban development in Eastern Europe'), www.los.shuttle.de/irs

Mironov, S. (2000) 'Vsemirnyj otel "St Petersburg"?' ('The World-Hotel "St Petersburg”?'), Ekspert North-West, 20 (27): http://archive.expert.ru/sever/00/00-20 26/20ogl.htm, 27 November.

Mögel, N. (1997) Allianzen auf Zeit? Zum Zusammenspiel von Regionalverwaltungen und Rüstungsunternehmen in Rußland (Alliances for the long term? On the interplay of regional administrations and armaments enterprises in Russia), Berichte des Bundesinstitutes, 43, Köln: Bundesinstitut für ostwissenschaftliche und internationale Studien.

Nedvizhimost Peterburga (1995, 1997, 2000, 2003) Analyticheskij spravochnik (The Real Estate Market in St Petersburg. A Guide and Analytical Annual), St Petersburg: Informacionno-izdatelskij centr.

Neef, R. and M. Stanculescu (eds) (2002) The Social Impact of Informal Economies in Eastern Europe, Aldershot: Ashgate.

Nikolskiy, I. V. (1982) 'Territorialnaya organizatsia torgovli v krupnykh gorodakh' ('Territorial organization of trade in large cities'), Vestnik MGU, Seria geograficheskaya 34 (2).

Nikulin, A. (2002) 'Russia', in Neef, R. and M. Stanculescu The Social Impact of Informal Economies in Eastern Europe, Aldershot: Ashgate.

OCC (Osteuropa Consulting Centre) (ed.) (1997) Die Entwicklung der Unternehmensstrukturen im Transformationsprozess Russlands, Berlin.

Ost-West-Contact - Wirtschaftsmagazin (1998) Russland - Zulauf bei Auslandsbanken, H. 12, pp. 35-6.

Ost-West-Contact - Wirtschaftsmagazin (2002) Messestandort St Petersburg, H. 12, 5, pp. 30-31.

Oswald, I. and V. Voronkov (2002) 'Der Sieg des Informellen. Verschränkung formeller und informeller Raumentwicklungsprozesse in St Petersburg' ('The victory of the informal. The intertwinement of formal and informal processes of spatial development in St Petersburg'), Nachrichtenblatt zur Stadt- und Regionalsoziologie, 16 (1): pp. 134-48.

Papadopoulos, A. and K. Axenov (2002) 'St Petersburg: Kioske als Mittler der neuen Marktwirtschaft' ('Kiosks as mediator of the new market economy'), in R. Schneider-Sliwa (ed.) Staedte im Umbruch (Cities in Change), Berlin: Reimer.

Peterburgkomstat 1995 (1996) Statisticheskij spravochnik (Statistical Yearbook), St Petersburg: Peterburgkomstat.

Peterburgkomstat 1997 (1998) Statisticheskij spravochnik (Statistical Yearbook), St Petersburg: Peterburgkomstat.

Peterburgkomstat 2000 (2001) Statisticheskij spravochnik (Statistical Yearbook), St Petersburg: Peterburgkomstat.

Peterburgkomstat 2001 (2002) Statisticheskij spravochnik (Statistical Yearbook), St Petersburg: Peterburgkomstat.

Peterburgkomstat 2002 (2003) Statisticheskij spravochnik (Statistical Yearbook), St Petersburg: Peterburgkomstat.

Petz, U and K. Schmals (1992) Metropole, Weltstadt, Global City: Neue Formen der Urbanisierung (Metropolis, Global City: New Forms of Urbanization) 
Editorial, Dortmunder Beiträge zur Raumplanung, 60, Dortmund: Institut für Raumplanung.

Pickles J. and A. Smith (eds) (1998) Theorising Transition. The Political Economy of Post-communist Transformations, London: Routledge.

Protasenko, T. Z., V. G. Revtova and O. S. Fadeeva (2000) 'Izmenenija v urovne zhizni i sotsialnaja atmosfera (Sankt Peterburg 1991-1999)' ('Changes in the level of life and social atmosphere (St Petersburg, 1991-1999)'), Telescope, 1: pp. 6-9.

Realtor 1995 (1): p. 11, St Petersburg (in Russian).

Regioniy Rossii (2003) 'Socialnoekonomicheskie pokazateli 2002. Statisticheskiy sbornik 2002', Goskomstat Rossii, Moscow.

Riley, R. and A. Niznik (1994) 'Retailing and urban managerialism: process and pattern in Lodz, Poland, Geographia Polonica, 63: pp. 25-36.

Roberts, A. (2003) 'Privatization and rent deregulation in Eastern Europe' in St. Lowe and S. Tsenkova (ed.) Housing Change in East and Central Europe: Integration or Fragmentation?, Aldershot: Ashgate.

Rossiskiy Statisticheskiy Yezhegodnik (2003) (Statistical Yearbook of Russia 2003), Goskomstat, Moscow.

Ruble, B. (1990) Leningrad: Shaping a Soviet City, Berkeley CA: University of California Press.

Rudolph, R. (1996) 'Citybildung in Moskau - Prozesse der funktionalen Differenzierung' ('Central Business District Formation in Moscow - Processes of Functional Differentiation'), thesis at the Free University of Berlin.

Rudolph, R. (1998) St Petersburg 1998, previously unpublished typescript, Leipzig: Institute of Regional Geography (IfL).

Rudolph, R. (1999a) Grundtendenzen der wirtschaftlichen Entwicklung in den 1990er Jahren in St Petersburg und Jekaterinburg (Basic Tendencies of Economic Development in the 1990s in St Petersburg and Yekaterinburg), previously unpublished typescript, Leipzig: Institute of Regional Geography (IfL).

Rudolph, R. (1999b) Regionale Besonderheiten der politischen und institutionellen Rahmenbedingungen in St Peterburg und Jekaterinburg (Regional Characteristics of the Political and Institutional Frameworks in St Petersburg and Yekaterinburg), previously unpublished typescript, Leipzig:, Institute of Regional Geography (IfL).

Rudolph, R. (2001) Stadtzentren russischer Großstädte in der Transformation - St Petersburg und Jekaterinburg (Downtowns in Large Russian Cities during Transformation - St Petersburg and Yekaterinburg), Beiträge zur regionalen Geographie 54, Leipzig: Leibniz-Institut fuer Laenderkunde.

Sailer-Fliege, U. (1999) 'Characteristics of post-socialist urban transformation in East Central Europe', GeoJournal, 49 (1): pp. 7-16.

Samochin, J., K. Liuhto and D. Achobadse (1993) St Petersburg Business Guide, Institute for East-West Trade, Turku School of Economics and Business Administration. Turku: Institute for East-West Trade.

Sankt-Peterburg $v$ zerkale statistiki (Saint-Peterburg in statistics) (1993), St Petersburg: Izdatelstvo S.-Peterburgskogo universiteta ekonomiki i finansov, Institute for East-West Trade.

Sassen, S. (1991) The Global City, New York, London, Tokyo, Princeton NJ: Princeton University Press.

Sassen, S. (1996) Metropolen des Weltmarktes (Metropolises of the World Market), Frankfurt am Main, New York: Campus. 


\section{Bibliography}

Shicharevitch, B. (2000) 'Replika is-sa schirmy (Reply as a defence)', Expert NorthWest 24 (17), http://archive.expert.ru/sever/00/00-17-23/17ogl.htm, 9 October.

Smirniagin, L. V., A. Y. Livshiz and A.V. Novikov (1994) 'Regionalnaya Strategia Rossii' ('Regional Strategy of Russia'), Regionalnaya Politika 6, Moskva: RAS.

Soja, E. (1993) 'Los Angeles, eine nach außen gekehrte Stadt: Die Entwicklung der postmodernen Metropole in den USA' ('Los Angeles, a city turned inside-out. The development of the post-modern metropolis'), in V. Kreibich et al. (eds) (1993) Rom-Madrid-Athen. Die neue Rolle der städtischen Peripherie, Dortmunder Beiträge zur Raumplanung 62, Dortmund: Institut für Raumplanung.

Stadelbauer, J. (1996) 'Die Nachfolgestaaten der Sowjetunion', in Wissenschaftliche Länderkunden, 4, Darmstadt: WBG.

Stahl, S. (1998) An Evolutionary Perspective in Transition Theory. Discussion Paper 9804, Jena: Max Planc Institute for Research of Economic Systems.

Standortführer Rußland - Strukturen, Erfahrungen, Kontakte (Location guide to Russia - Structures, experiences, contacts) (1994) Hamburg: Frankfurter Allgemeine Zeitung $\mathrm{GmbH}$ - Informationsdienste.

Stark, D. (1992) 'Path dependence and privatisation strategies in East-Central Europe', East European Politics and Societies (4): pp. 351-92.

Stenning, A. C. (1997) 'Economic restructuring and local change in the Russian Federation', in M. J. Bradshaw (ed.) Geography and Transition in the Post-Soviet Republics, Chichester, Sussex: Wiley.

Stenning, A (2004) 'Urban change and the localities', in M. Bradshaw and A. Stenning (eds) East Central Europe and the Former Soviet Union: The PostSocialist States, Harlow: Pearson, pp. 87-108.

Strategic Plan (1998) Strategic Plan for St Petersburg, St Petersburg: Leontiefskij centr. English version available at http://stratplan.leontief.ru/draft/special.htm.

Streit, M. and U. Mummert (1996) Grundprobleme der Systemtransfomation aus institutionenökonomisher Perspektive (Fundamental Problems of Systemic Transformation from an Institutional Economics Perspective), Diskussionsbeitrag 09-96, Jena: Max-Plank-Institut zur Erforschung von Wirtschaftssystemen.

Szelenyi, I. (1996): 'Cities under socialism - and after', in G. Andrusz, M. Harloe and I. Szelenyi (eds) Cities after Socialism. Urban and Regional Change and Conflict in Post-socialist Cities, Oxford: Blackwell.

Taylor, P. and M. Hoyler (2000) 'The spatial order of European cities under conditions of contemporary globalization', Tijdschrift voor economische en sociale Geografie, 91 (2): pp. 176-89.

Taylor, P. (2001) 'Urban hinterworlds: Geographies of corporate service provision under conditions of contemporary globalization', Geography, 1: pp. 59-60.

Treivish, A., I. Brade and T. Nefedova (1999) 'Russian cities at a crossroads', GeoJournal, 49 (1): pp. 117-29.

Vendina, O. (ed.) (1994) Eine Stadt verändert ihr Gesicht (A City Alters its Image), Berichte des Bundesinstitutes für ostwissenschaftliche und internationale Studien, 43, Köln: Bundesinstitut für ostwissenschaftliche und internationale Studien.

Vendina, O. (1997) 'Transformation processes in Moscow and intra-urban stratification of population', GeoJournal, 42 (4) pp: 349-63.

Vendina, O. and I. Brade (1996) 'Der Immobilienmarkt in Moskau - Grundtendenzen der 90er Jahre' ('The Real Estate Market in Moscow - Basic Tendencies of the 1990s'), Europa Regional, 4 (2): pp. 17-28.

Verkehrsnachrichten (Traffic News), 12/1996, BMV-Journal, p. 13, Bulletin. 
Vetrov, G. (2002) Principal Changes in Municipal Economic Development in 1998-2000, Moscow: The Institute for Urban Economics, English version available at www.urbaneconomics.ru/eng/activity/development/part01.html.

Wallerstein, I. (1974) The Modern World-System, New York: Academic Press.

Wallerstein, I. (1979) The Capitalist World-Economy, Cambridge: Cambridge University Press.

Wallerstein, I. (1980) The Modern World-System II, New York: Academic Press.

Yeates, M. (1990) The North American City, New York: Harper \& Row.

Zapf, M. (1998) 'Modernisierung und Transformation' ('Modernization and transformation'), in B. Schäfers and W. Zapf (eds) Handwörterbuch zur Gesellschaft Deutschlands, Opladen: Leske und Budrich. 



\section{Index}

administrative regulation $24,59,64,67$, $74-5,84,99,167,182$

agglomeration 4, 6, 7, 17, 74, 76, 78, 82-90, 93, 95, 98-100, 103, 105, $138-40,144,175$

business centre $42,64,143,149,151$, $156,170-3,177$

business-oriented service $13,44,52$

business zone 4, 177; see also office zone

central business district (CBD) 63, 149

centrality $111,114-18,122-5,128-36$, 177

chain $63,103,105,148,153,156-65$, $168,172,177$

city centre $4,6-7,13,111,114$, 116-21, 128-9, 131-2, 134, 138, $141,146,148-50,161,167-8,172$, 183-4

city planning 180 ; see also urban planning

decentralization 12,179

demand structure 154

discounter 156, 165-6, 169, 177

distribution pattern 99, 114, 119

Eastern Europe 1, 8-12, 17-20, 29, 37, 42, 179

Fordism 4, 176, 179

functional zone 82-4, 116, 119-22

gentrification 6-7

global cities 1-2, 4-5

globalization 1-2, 8, 18, 24, 178 headquarters 38,46

headquarter economy 5

high-quality service 6

hybrid spatial structure 176

hybrid urban structure 178

hypermarket $13,110,153,156-65,168$, 172,177

industrial zone $112,114-18,121,128$, $132,134-5$

informal economy 13,52

informal regulation 64, 67, 70, 178

informal sector 11,13

internationalization 2, 4, 8, 14

Iron Curtain 33, 36-7

joint territorial attraction 112, 138, 141

kiosk 13, 53, 56, 69, 73-96, 99-105, 107, 138-40, 143-4, 161, 164-5, $166-9,175,177$

local actor 37

local authority $12,15-16,37,50,55$

locational preference $61,111-13,115$, $152,156,178$

low level 24, 149, 155

maliy biznes 13, 52; see also small business

market infrastructure 45-6, 68

market place $80,90-5,100,167$

mobile trade 75-7, 79, 82, 90, 93, 105, 113,133

modernization $17,20-7,110,174-6$, 178

multifunctional complex 156, 157, 167, 168,177

multiplication effects 36 


\section{Index}

new poor $156,169,177$

office zone 6, 123, 143; see also business zone

pavilion 53, 73, 75, 90-5, 98-105, 161,177

periphery 2, 5-7, 10, 111

post-Fordism 4, 7, 176

post-socialist metropolis 8

post-transformation 17, 22-3, 25-7, $63,67,70-2,75-6,103,108,111$, $152,154-6,159,161,163,165$, $168,170-1,173-8$

privatization 13-16, 25, 47, 49, 52, $57-8,179$

redevelopment $6,11,93,161,172$ residential area $3,7,15,77,80$, $103,112,115,117$

segregation 2, 4, 7, 10, 18, 91

shopping mall $6,167-8$

shopping model $82,87,90,99$, $106,110,152,154,159,173$, $176-8$

small business $5,13,15,37,50$, 52-3, 70, 92, 181; see also maliy biznes

socialist city $10-11,15,18,23-4$, $26-7,62,175-6,183$

spatial competition $61,62,114$, 117-20, 128-9, 132, 134-6, 159, $161,163,166-7,170$

spatial dynamics $1,21,27,177$

spatial organization $12,24,27,68$, $72,144,152,178$

spatial process $27-8,175$

spatial restructuring 1

spatial saturation 23, 26, 56, 61-3, 72, 89-111, 137, 144, 152, 154, 175 spatial structure $3,6,15,17,22-8,55$, $72,75,93,95,103,105,135,136$, $155-6,175-6$

state institution 14, 67

street trader $79,80,90,92,96$

structural transformation 55

suburbanization 3, 5

territorial complex 62, 63, 107, 137-69, 175,177

territorial cooperation $111,112,144$, 150,151

tertiarization $1,4-5,12,19$

tertiary sector $10,11,14,16-17,38$, 54-5, 143-4, 146, 149-51, 174-5

trade complex $74,98,100,102-4$

trade zone $74,75,90-5,99-102,105$, 156,177

trading space $26,56,73-7,80,90$, $103,107,142,153-4,157-62,165$, 168

transformation trade forms $72,74,103$, 105,178

transition 2, 4-5, 19-21, 60, 90, 120, $175-6$

transnational level 1

transportation model 129

transportation pattern $91,110,123$, 126,130

urban development $1,3-7,11-12$, $16-19,37,55,68,179$

urban morphology 115, 126, 136, 178

urban periphery 5,6

urban planning 15; see also city planning

urban space $2-3,10,19,23-5,27,37$, $63,67,72,75,178$

vertical business structures $61,107-36$, 137,144 
eBooks - at www.eBookstore.tandf.co.uk

\section{A library at your fingertips!}

eBooks are electronic versions of printed books. You can store them on your PC/laptop or browse them online.

They have advantages for anyone needing rapid access to a wide variety of published, copyright information.

eBooks can help your research by enabling you to bookmark chapters, annotate text and use instant searches to find specific words or phrases. Several eBook files would fit on even a small laptop or PDA.

NEW: Save money by eSubscribing: cheap, online access to any eBook for as long as you need it.

\section{Annual subscription packages}

We now offer special low-cost bulk subscriptions to packages of eBooks in certain subject areas. These are available to libraries or to individuals.

For more information please contact webmaster.ebooks@tandf.co.uk

We're continually developing the eBook concept, so keep up to date by visiting the website.

www.eBookstore.tandf.co.uk 